\title{
ZUSES
}

\section{Geologic Map of the Bonanza Caldera Area, Northeastern San Juan Mountains, Colorado}

By Peter W. Lipman

Pamphlet to accompany

Scientific Investigations Map 3394

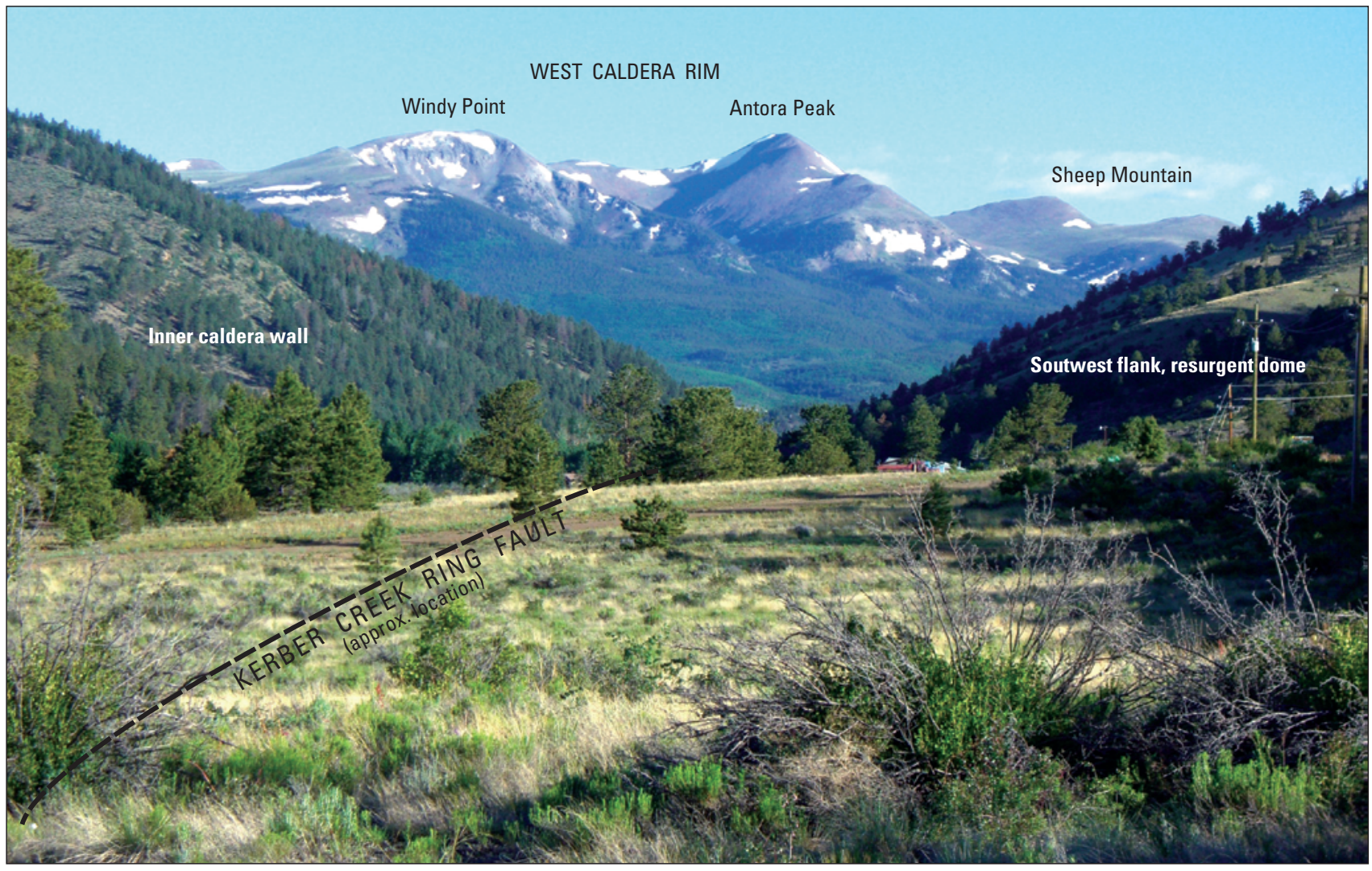

U.S. Department of the Interior

U.S. Geological Survey 


\title{
U.S. Department of the Interior DAVID BERNHARDT, Secretary
}

\author{
U.S. Geological Survey \\ James F. Reilly II, Director
}

U.S. Geological Survey, Reston, Virginia: 2020

For more information on the USGS - the Federal source for science about the Earth, its natural and living resources, natural hazards, and the environment—visit https://www.usgs.gov or call 1-888-ASK-USGS.

For an overview of USGS information products, including maps, imagery, and publications, visit https://store.usgs.gov.

Any use of trade, firm, or product names is for descriptive purposes only and does not imply endorsement by the U.S. Government.

Although this information product, for the most part, is in the public domain, it also may contain copyrighted materials as noted in the text. Permission to reproduce copyrighted items must be secured from the copyright owner.

Suggested citation:

Lipman, P.W., 2020, Geologic map of the Bonanza caldera area, northeastern San Juan Mountains, Colorado: U.S. Geological Survey Scientific Investigations Map 3394, 73 p., 2 sheets, scale 1:50,000, https://doi.org/10.3133/ sim3394.

Associated data for this publication:

Robinson, J.E., and Lipman, P.W., 2020, Database for the geologic map of the Bonanza caldera area, northeastern San Juan Mountains, Colorado: U.S. Geological Survey data release, https://doi.org/10.5066/P9110L40.

ISSN 2329-1311 (print)

ISSN 2329-132X (online)

Cover Photograph. West topographic rim of Bonanza caldera, as viewed to northwest, up valley of Kerber Creek. In distance, Antora Peak (center, 13,269') is capped by densely welded dacitic Bonanza Tuff (33.12 Ma), while Windy Point (left, 12,800') exposes thin layer of basal rhyolitic Bonanza Tuff that has undergone local rheomorphic flowage. Lower slopes of both high points are west-dipping sequence of interlayered andesitic lavas and volcaniclastic rocks that make up the erosionally modified inner wall of Bonanza caldera. Sheep Mountain (right distant skyline, 12,228') is pre-Bonanza dacitic lava dome (33.78 $\mathrm{Ma}$ ) that partly fills the older Marshall caldera, source of the 33.9-Ma Thorn Ranch Tuff. On left side of Kerber Creek, timbered slope is lower portion of southwest caldera wall; on right side of creek is dip slope on flank of postcollapse resurgent dome. The valley of Kerber Creek coincides with the main ring fault, along which more than $3 \mathrm{~km}$ of subsidence was accommodated during eruption of the Bonanza Tuff and concurrent caldera collapse. 


\section{Contents}

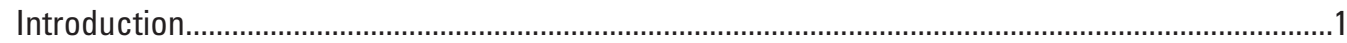

Ignimbrite Caldera Cycles and Eruptive Processes..........................................................................2

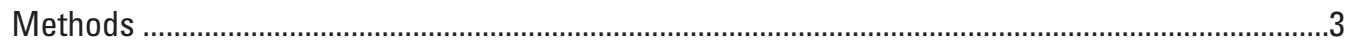

Regional Framework of the Southern Rocky Mountain Volcanic Field .........................................5

Paleotopography and Structure ...................................................................................................5

Early Northern Volcanism along the Sawatch Trend...........................................................

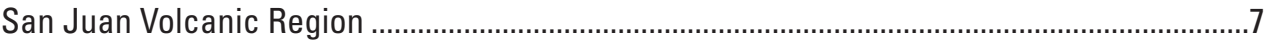

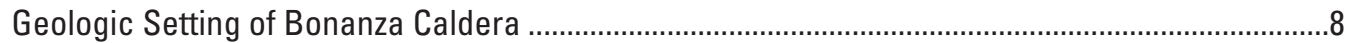

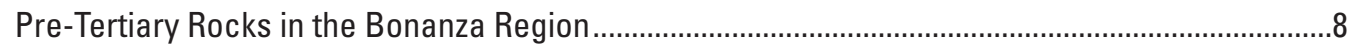

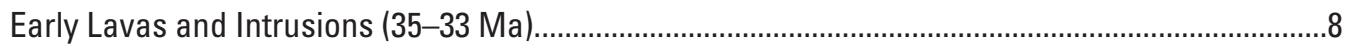

Thorn Ranch Tuff and Marshall Caldera Cycle (33.9 Ma)............................................................10

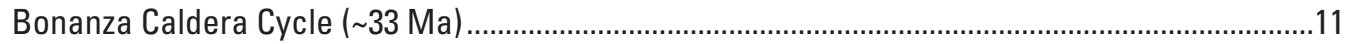

Pre-Bonanza Caldera Volcanism ...................................................................................... 12

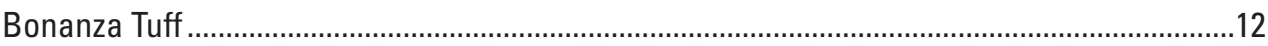

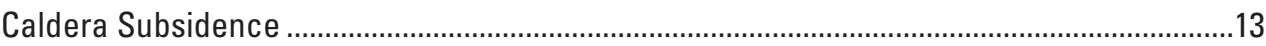

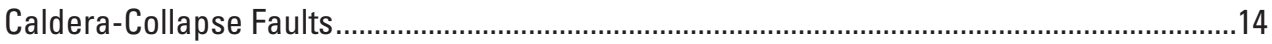

Caldera-Floor Structures ........................................................................................................ 15

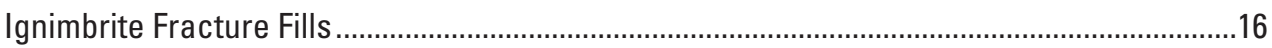

Ignimbrite and Subsidence Volumes .....................................................................................16

Postcollapse Lavas and Intrusions ......................................................................................17

Resurgent Uplift.................................................................................................................

An Additional Complexity .........................................................................................................19

Initial and Present-Day Caldera Morphology ...........................................................................20

Younger Eruptions from other San Juan Calderas (28.3-26.9 Ma) ..................................................22

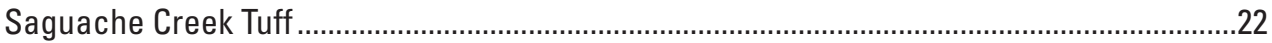

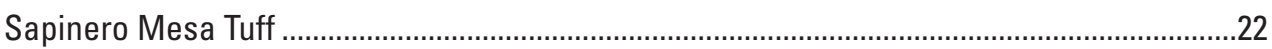

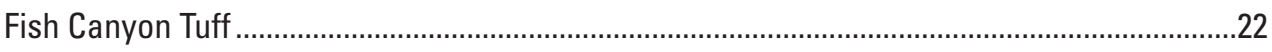

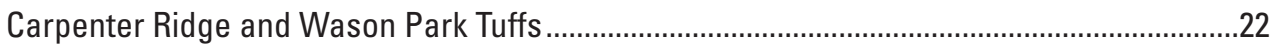

Younger Intermediate-Composition Lavas....................................................................................22

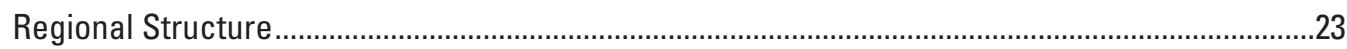

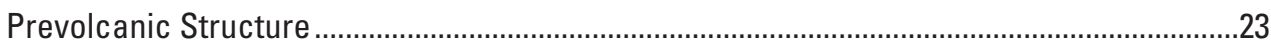

Rio Grande Rift and Transfer-Zone Geometry...................................................................24

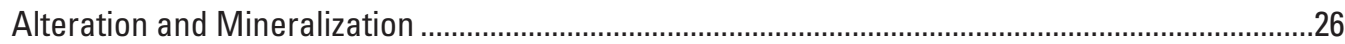

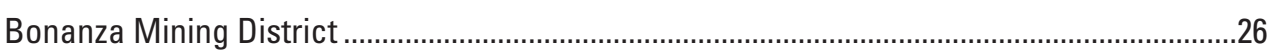

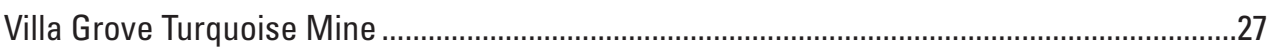

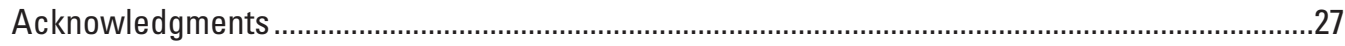

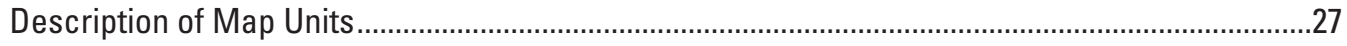

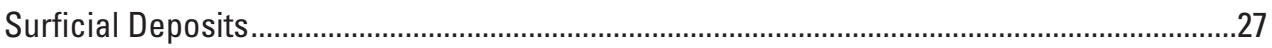

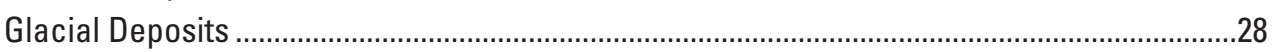

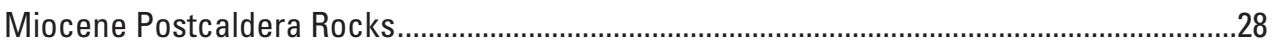

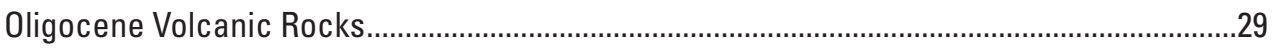

Ignimbrites and Associated Rocks of the Central San Juan Caldera Complex ..............29

Rocks Erupted from South River Caldera (27.4 Ma) ...................................................29

Rocks Erupted from Bachelor Caldera (27.55 Ma) ...................................................29

Rocks of La Garita Caldera Cycle (28.0 Ma) ...............................................................30

Local Volcaniclastic Rocks of Saguache Paleovalley...............................................31

Older Ignimbrite Related to Western San Juan Calderas (28.3 Ma) ........................31 
Caldera-Related Rocks Predating the Western and Central Caldera Clusters ...............33

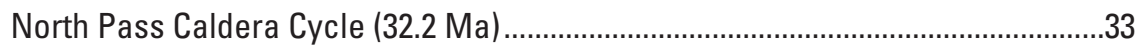

Rocks of the Bonanza Caldera Cycle (33 Ma) .....................................................33

Volcanic Rocks Predating Bonanza Caldera..............................................................44

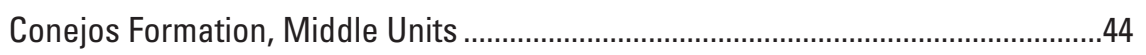

Tracy Volcano (<32.5?-33.5 Ma) ............................................................... 44

Sargents Mesa Volcano ………................................................................. 48

Rawley Volcanic Complex ( 33.2-33.8 Ma) ................................................49

Rocks of the Marshall Caldera Cycle (33.8-33.9 Ma) .............................................53

Sawatch Range Ignimbrite (Erupted from Aetna Caldera) ......................................55

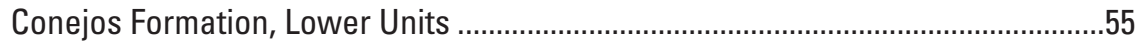

Jacks Creek Volcano ( $34.5 \mathrm{Ma})$....................................................................5

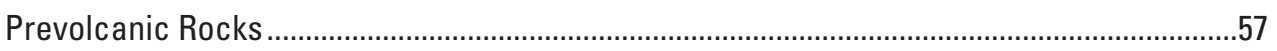

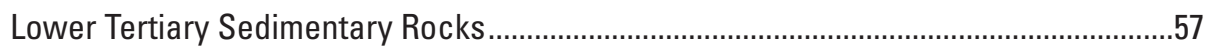

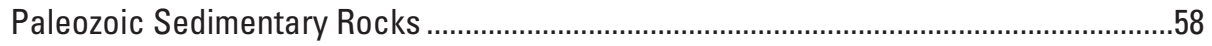

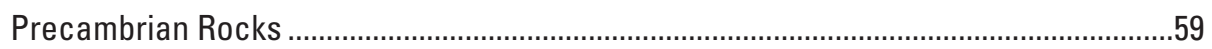

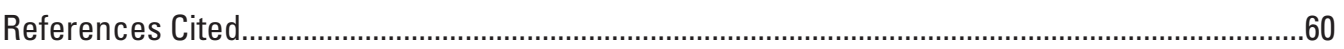

\section{Photographic Essay}

Available online at https://doi.org/10.3133/sim3394

\section{Figures}

1. Map of Southern Rocky Mountain Volcanic Field (SRMVF), showing ignimbrite calderas, major erosional remnants and inferred original extent of middle Tertiary volcanic cover, caldera-related granitic intrusions, and later sedimentary fill in asymmetric grabens of the Rio Grande rift

2. Map showing calderas of the San Juan volcanic region and location of map area....sheet 2

3. Map of northeastern San Juan region, showing areas of geologic mapping responsibilities, $7.5^{\prime}$ topographic quadrangles with names and abbreviations used on maps and in text, and 1:50,000-scale county maps. sheet 1

4. Generalized geologic map and cross section, northeastern San Juan region, based on recent geologic mapping (2000-2011) sheet 1

5. Oblique view of Bonanza caldera area, viewed from the south. sheet 2

6. Alkali-silica diagram, showing compositional variations in rocks of the Bonanza map area sheet 2

7. A. Summary of ${ }^{40} \mathrm{Ar} /{ }^{39} \mathrm{Ar}$ age determinations for igneous rocks of the Bonanza region, illustrating the narrow weighted-mean ages obtained for multiple samples of individual ignimbrites, lavas, and intrusions of the Bonanza cycle. B. Eruptive chronology of the Bonanza region shows precursors to eruption of the Bonanza Tuff, including several central volcanoes and Marshall caldera, source of the Thorn Ranch Tuff at 33.9 Ma

8. Age-location-volume plot, showing southward progression of Tertiary ignimbritecaldera volcanism in the Southern Rocky Mountain Volcanic Field ...sheet 2

9. Diagrammatic stratigraphic relations between regional ignimbrites and early intermediate-composition lavas (Conejos Formation), northeastern San Juan region... sheet 2

10. Generalized geologic map of Bonanza and Marshall calderas, showing major stratigraphic units, structural features, and locations of cross sections sheet 2 
11. Diagrammatic cross section through concealed south margin of Marshall caldera, showing inferred relations of caldera-filling volcanic units. sheet 2

12. Areal extent of preserved erosional remnants of Bonanza Tuff...............................sheet 2

13. Generalized regional thickness and compositional variations in the Bonanza Tuff.....sheet 2

14. Cross sections, showing structures and stratigraphic relations across Bonanza caldera. sheet 2

15. Geologic map of sheet-like mass of flow-layered rhyolite, interpreted as rheomorphic lower Bonanza Tuff (Tbrr), along upper Schoolhouse Gulch. sheet 2

16. Panoramic view across crest of Whale Hill resurgent dome, eastward toward San Luis Valley (Rio Grande rift), from west rim of Bonanza caldera sheet 1

\section{Tables}

1. Summary of major ignimbrites, caldera sources, and ${ }^{40} \mathrm{Ar} /{ }^{39} \mathrm{Ar}$ ages, Southern Rocky Mountain volcanic field, southwestern Colorado

2. Characteristic features, ignimbrite sheets of central and northeastern San Juan Mountains, southwestern Colorado.

3. Representative compositions, volcanic and intrusive rocks of Bonanza caldera region, southwestern Colorado.

4. Summary of ${ }^{40} \mathrm{Ar} /{ }^{39} \mathrm{Ar}$ age determinations, Bonanza caldera and northeastern San Juan regions, southwestern Colorado

5. Chemical compositions, rocks of Bonanza caldera region, southwestern Colorado ...https://doi.org/10.3133/sim3394

6. Summary of ${ }^{40} \mathrm{Ar} /{ }^{39} \mathrm{Ar}$ age determinations, rocks of Bonanza caldera region, southwestern Colorado... ...https://doi.org/10.3133/sim3394 


\title{
Geologic Map of the Bonanza Caldera Area, Northeastern San Juan Mountains, Colorado
}

\author{
By Peter W. Lipman
}

\section{Introduction}

The San Juan Mountains in southwestern Colorado (fig. 1, sheet 1) have long been recognized as a site of exceptionally voluminous middle Tertiary volcanism (Cross and Larsen, 1935; Larsen and Cross, 1956), including at least 24 major ignimbrite sheets (each $150-5,000 \mathrm{~km}^{3}$ ) and associated caldera structures active at 33-23 Ma (fig. 2, sheet 2; tables 1, 2; Steven and Ratté, 1965; Lipman and others, 1970; Steven and Lipman, 1976). More recent volcanologic and petrologic studies in the San Juan region have focused mainly on several ignimbrite-caldera systems: the southeastern area (Platoro complex: Lipman, 1975; Dungan and others, 1989; Lipman and others, 1996), western calderas (Uncompahgre-Silverton-Lake City: Lipman and others, 1973; Hon and Lipman, 1989; Bove and others, 2001; Kennedy and others, 2016), and the central cluster (La Garita-Creede calderas: Lipman and others, 1989, 1997; Riciputi and others, 1995; Lipman, 2000, 2006; Schmitz and Bowring, 2001; Bachmann and others, 2002, 2007; Parat and others, 2005). Two regional summaries explored relations between overall evolution of the composite Southern Rocky Mountain volcanic field (SRMVF) and associated intrusions, the large erosional remnant in the San Juan region, and broader aspects of Cordilleran batholithic magmatism (Lipman, 2007; Lipman and Bachmann, 2015).

Far less studied until recently has been the northeast San Juan region (figs. 3, 4, sheet 1), which occupies a transition between earlier volcanism in central Colorado and the largervolume younger ignimbrite-caldera foci farther south and west (fig. 1). Landmark early 20th-century studies of the San Juan region (Cross and Larsen, 1935; Larsen and Cross, 1956) largely concentrated on areas farther to the south and west, in part because topographic map coverage was minimal north of the 38th parallel. Renewed regional work in the middle 20th century focused on mapping the Durango $2^{\circ}$ quadrangle at a scale of 1:250,000 (Steven and others, 1974) and documented presence of widespread ignimbrite sheets and their source calderas in the San Juan Mountains (Steven and Lipman, 1976); this study again was limited to areas south of the 38th parallel. Other than framework mineral-resource studies of small areas (for example, Scott and others, 1975; Van Alstine, 1975; Olson, 1988), much of the northeastern San Juan region has previously been covered only in rough reconnaissance for the Colorado State geologic map (Tweto and others, 1976; Tweto, 1979).
Presence of a northeastern caldera at Cochetopa Park was recognized during these regional studies (Steven and Lipman, 1976; Steven and Bieniewski, 1977), but its eruptive history remained confusing (Lipman, 2000). Based on more recent field, petrologic, and geochronologic studies, Cochetopa is now recognized as an unusual noneruptive caldera that subsided in response to an ignimbrite eruption (Nelson Mountain Tuff) at 26.9 Ma from a source $25 \mathrm{~km}$ farther to the southwest (Lipman and McIntosh, 2008; Lipman, 2012). These studies also led to identification of the previously unrecognized North Pass caldera as a source for the newly distinguished 32-Ma Saguache Creek Tuff, a large-volume ignimbrite of phenocryst-poor rhyolite that previously had been erroneously correlated with the $28-\mathrm{Ma}$ Sapinero Mesa Tuff (Bruns and others, 1971). Despite these discoveries, uncertainties have continued about stratigraphic and structural relations with the large areas of volcanic rocks farther east along the Saguache Creek valley, the Bonanza region to the northeast, and the older middle Tertiary ignimbrite sources (Grizzley Peak, Princeton, Aetna) that are aligned along the Sawatch Range to the north (Fridrich and Mahood, 1987; Fridrich and others, 1998; Shannon, 1988; Johnson and others, 1989; Toulmin and Hammarstrom, 1990; McIntosh and Chapin, 2004).

Existence of a caldera has long been inferred in the Bonanza region, based on gravity data (Karig, 1965) and regional reconnaissance studies (Steven and Lipman, 1976; Varga and Smith, 1984), but detailed geologic mapping, petrologic information, and geochronologic data have been sparse. The only previously published geologic maps for the Bonanza region were a pioneering report focused narrowly on the Bonanza mining district by Patton (1916) and a more detailed study of the district at a scale of 1:12,000 (Burbank, 1932). These studies distinguished the major local rock units and provided information on mine workings, but these were undertaken before development of modern concepts for ignimbrite volcanism and associated caldera subsidence. Several graduate theses at the Colorado School of Mines in the late 1960s and early 1970 s, using the Bonanza region as a ground-truth test area for remote-sensing data, provided lithologic information of varying detail for small areas adjacent to the mining district (Bridwell, 1968; Mayhew, 1969; Kouther, 1969; Perry, 1971; Knepper and Maars, 1971; Maars, 1973). These studies included recognition that the unit named Bonanza latite and interpreted as a thick sequence of lavas by Patton (1916), who carefully described the 
distinctive presence of abundant small fragments of andesite and puzzled over its rhyoclastic texture, consisted of welded tuff (Bruns and others, 1971).

Concurrently, a detailed stratigraphy for outflow ignimbrites (ash-flow tuffs) was developed in the Thirtynine Mile volcanic area farther to the northeast (fig. 1; Chapin and Epis, 1964; Epis and Chapin, 1968, 1974), but with insufficient regional control to locate source areas unambiguously. As an outgrowth of renewed mineral exploration for porphyry deposits at depth below the vein mineralization at Bonanza, Varga and Smith (1984) synthesized available regional data, augmented by new chemical and isotopic analyses, as evidence for a modest trap-door caldera ( $~ 8$ $\mathrm{x} 12 \mathrm{~km}$ ) in the mining district as a source of a relatively small eruption $\left(<50 \mathrm{~km}^{3}\right)$ that produced the Bonanza Tuff. More recent geochronologic and paleomagnetic studies of distal ignimbrites in the Thirtynine Mile area, and comparisons with intracaldera ignimbrites and associated rocks along the Sawatch trend as far south as Bonanza, demonstrated that one of the distal eastern ignimbrites, the Gribbles Park Tuff of Epis and Chapin (1974), is indistinguishable in age and paleomagnetic direction from proximal Bonanza Tuff (McIntosh and Chapin, 2004). Despite these discoveries, uncertainties have continued about stratigraphic and structural relations in the Bonanza region and with the middle Tertiary ignimbrite sources (Grizzley Peak, Princeton, Aetna) that are aligned along the Sawatch Range to the north (Shannon, 1988; Johnson and others, 1989; Toulmin and Hammarstron, 1990; Fridrich and others, 1998; McIntosh and Chapin, 2004).

The town of Bonanza (photo 1; see photographic essay at https://doi.org/10.3133/sim3394), the only settlement within outcropping parts of Bonanza caldera, was a thriving boomtown in the 1880s that was known to include 36 saloons and seven dance halls (Patton, 1916, p. 9) when exploration activity was at its peak. Bonanza's early population has been estimated at 1,000 to 2,000 (Cappa and Wallace, 2007). The boom slowed in the 1890s, but some mining and exploration persisted into the middle 20th century. At present, Bonanza has the distinction of being Colorado's least populated incorporated town, with 16 permanent residents, according to the 2010 Census (and reportedly only two in 2014). Most mine workings in the Bonanza district have become inaccessible, and the only substantial mineralization studies since the middle 20th century have involved exploration, mainly by core drilling, of the potential for porphyry molybdenum deposits (Cook, 1960; Gordon Gumble, written commun., 1982).

This study of the Bonanza caldera area evaluates eruptive and magmatic processes of silicic Cordilleran volcanism, based on new geologic mapping (mainly summers of 2007-11) and concurrent petrologic and geochronologic analysis. The resulting map is based on field coverage of volcanic rocks in thirteen 7.5' quadrangles in northeastern parts of the volcanic field (figs. 3, 4), petrologic studies involving several hundred new chemical analyses (tables 3, 4), and high-resolution age determinations for about 130 sites (tables 5, 6, https://doi.org/10.3133/sim3394; McIntosh and Chapin, 2004; Lipman and McIntosh, 2008; Lipman and others, 2015). The Bonanza center contains exceptionally complete and diverse features of an ignimbrite caldera cycle, including voluminous andesite erupted before and after ignimbrite eruptions, complex compositional zonation within both the outflow ignimbrite sheet and the tuff concurrently ponded within the caldera, extensive portions of the ring-fault system that accommodated subsidence, thick compositionally diverse lavas that filled the caldera after subsidence, remnants of the original topographic caldera rim, widespread erosional exposure of caldera-floor features, and postcaldera granitic intrusions that generated a notably steep resurgent dome within the caldera.

Among topics examined are some little-understood complexities of pyroclastic eruption and emplacement, volumes of outflow and intracaldera ignimbrite in relation to caldera size and inception of subsidence, geometric interrelations between caldera subsidence and resurgence, petrologic diversity of sequential eruptions that formed a single ignimbrite, recurrent eruption of intermediate-composition lavas after caldera-forming events, associated regional fault development, emplacement of subvolcanic plutons, involvement of mantle-derived components in magma generation, and time-space-volumecompositional progressions in the SRMVF. This mapping and accompanying lab results (1) constrain volcanic evolution of the previously little known Marshall caldera (fig. 2) as the source of the 34-Ma Thorn Ranch Tuff (Gregory and McIntosh, 1996) prior to inception of the 33-Ma Bonanza eruptive cycle; (2) document complex compositional zonations and areal-distribution variations during eruption of the Bonanza Tuff; (3) define a much larger Bonanza caldera than previously recognized (fig. 5 , sheet 2), including an elliptical steep-sided central resurgent uplift and a coherent multi-kilometer-thick volcanic sequence of caldera-filling ignimbrite and overlying postcollapse lavas; (4) document exposed caldera-floor volcanic rocks and underlying Paleozoic and Proterozoic basement rocks that provide evidence for structurally coherent subsidence bounded by ring faults, including unique features not previously described from ignimbrite calderas elsewhere; (5) demonstrate a more episodic recurrence of large ignimbrite eruptions in the San Juan region than previously recognized; (6) quantify regional time-spacevolume-compositional progressions from the earlier Sawatch magmatic trend southward into the San Juan region; and (7) permit more rigorous comparison between the broad middle Tertiary magmatic belt in the western U.S. Cordillera and the type continental-margin arc volcanism in the central Andes.

This pamphlet provides (1) a guide to the geologic evolution of Marshall and Bonanza calderas within a conceptual framework of caldera processes and the regional setting for these newly interpreted caldera systems within the SRMVF of middle Tertiary age (Lipman, 2007; Lipman and Bachmann, 2015) and (2) brief descriptions for each of the rock units depicted on the accompanying geologic map. The pamphlet is a more descriptive sequel to a previously published interpretive report (Lipman and others, 2015), based on the Bonanza caldera map.

\section{Ignimbrite Caldera Cycles and Eruptive Processes}

As previously interpreted for silicic volcanism in the San Juan Mountains and elsewhere, lavas, volcaniclastic sedimentary rocks, and intrusions emplaced concurrently with ignimbrites in the northeastern San Juan region define multiple 
caldera cycles, based on affinities of geographic distribution and stratigraphic sequence, isotopic ages and paleomagnetic pole positions, and petrologic character. Interpretation of some units remains ambiguous, especially assignment of certain lavas and tuffs to the late stages of one cycle versus inception of the next one. The revised analysis of caldera development and regional volcanic history (table 1) builds upon earlier syntheses for the San Juan region (Lipman and others, 1970, 1978; Steven and Lipman, 1976; Lipman, 2000), utilizing general concepts of caldera geometry and eruptive cycles summarized by Smith and Bailey (1968) and Lipman (1984, 1997, 2007). These overview papers provide a framework for broader understanding of the map relations depicted on this map.

Large ignimbrite calderas, such as those in the San Juan region, form at sites of preceding volcanism that record shallow accumulation of caldera-related magma. Large eruptions $(>50$ $100 \mathrm{~km}^{3}$ of ignimbrite magma) cause caldera collapse concurrently with volcanism, as indicated by thick intracaldera ignimbrite fill and interleaved collapse breccias. Volumes of intracaldera and outflow tuff tend to be subequal; correlation between them is commonly complicated by contrasts in abundance and size of phenocrysts and lithic fragments, degree of welding, devitrification, alteration, and even chemical composition of magmatic material. Structural boundaries of calderas commonly are single ring faults or composite ring-fault zones that dip steeply. Scalloped topographic walls beyond the structural boundaries of most calderas are due to secondary gravitational slumping during subsidence. The area and volume of caldera collapse are roughly proportional to the amount of erupted material. Postcollapse volcanism may occur from varied vent geometries within ignimbrite calderas; ring-vent eruptions are most common in resurgent calderas, reflecting renewed magmatic pressure. Resurgence within calderas may result in a symmetrical dome or more geometrically complex forms. In addition to resurgence within single calderas, broader magmatic uplift occurs within some silicic volcanic fields, reflecting isostatic adjustment to emplacement of associated subvolcanic batholiths. Large intrusions related to resurgence are exposed centrally or along the margins of some deeply eroded calderas, and geophysical data documents the presence of a composite subvolcanic batholith that encompasses most calderas of the San Juan region (Plouff and Pakiser, 1972; Drenth and others, 2012). Hydrothermal activity and mineralization accompany all stages of ignimbrite magmatism, becoming dominant late during caldera evolution. Mineralization commonly occurs millions of years after caldera collapse, when the caldera serves primarily as a structural control for late intrusions and associated hydrothermal systems.

\section{Methods}

Geologic mapping of western fringes of the Bonanza caldera area, initiated to resolve overlapping problems with the adjacent Cochetopa-North Pass geologic map (Lipman, 2012; Lipman and others, 2013), was gradually expanded to cover Bonanza and adjacent areas to the northeast (figs. 3, 4) as multiple stratigraphic, structural, geochronologic, and volcanologic complexities emerged. New field studies totaled about 50 weeks between 2006 and 2015 (mainly 2007-2011); immensely helpful month-long fieldwork assistance was provided by Andrea Sbisà during each of three core summers (2008-10). Field collaborations with William McIntosh and Matthew Zimmerer during every field season, aimed at sampling for geochronologic study and resolving interpretive problems emerging from the age determinations (Lipman and others, 2015), were invaluable in generating this map product (photo 2). Petrologic and isotopic studies undertaken by Valibone Memeti, during tenure as Madame Curie postdoctoral fellow at Durham University, have provided additional insights for magmatic evolution of the Bonanza system (Memeti and Lipman, 2014).

Prior to this study, systematic geologic mapping was largely lacking as a framework for interpreting volcanic and petrologic evolution of Bonanza and Marshall calderas. The detailed map of the Bonanza mining district by Burbank (1932) provided guidance for rock distribution in a small part of the study area, but many stratigraphic assignments and structural interpretations, made without modern concepts of volcanic processes, were unreliable. A map of the 7.5' Lake Mountain northeast quadrangle (Bruns and others, 1971), undertaken for a M.S. thesis at the Colorado School of Mines, was especially helpful for that area. Concurrently, studies of smaller adjacent areas, reported in several unpublished theses (Bridwell, 1968; Kouther, 1969; Mayhew, 1969; Perry, 1971), provided varying levels of detail. Elsewhere, the most recent published geologic mapping was a reconnaissance compilation of the Saguache $2^{\circ}$ sheet at 1:250,000-scale (Tweto and others, 1976), devised to provide coverage for the Colorado State geologic map (Tweto, 1979).

In much of the Bonanza region, field studies are impeded by vegetative cover, steep terrain, and widespread talus. As lamented long ago during a pioneering study of the Bonanza mining district by Patton (1916, p. 12) "actual rock outcroppings are not abundant $* * *$. The heavy soil and the thick tree growth $* * *$ made it difficult if not impossible to map the geologic formations with great exactness." For this work, these limitations have been partly offset by ability to obtain precise GPS locations for critical areas, but resolution of lithologic relations remains far less certain for many areas than implied on the 1:12,000-scale geological map of Burbank (1932).

This fieldwork and primary map compilation were at a scale of 1:24,000, using 7.5' topographic quadrangle maps as base materials (fig. 3); these data are included as digital files in the database at https://doi.org/10.5066/P911OL4Q. In total, 147 map units are distinguished. The digital files were compiled using ArcMap GIS software, jointly with Joel Robinson. The geologic map data were transferred by GIS methods to 1:50,000scale county topographic maps to provide a more legible base than would have been possible by reduction of the 1:24,000scale quadrangle maps. The map area is bounded to the east by surficial deposits of the San Luis Valley and to the north by the Saguache County Line, except for extending 1-2 km into Chaffee County northwest of Poncha Pass (PO, fig. 3) to constrain some structural and stratigraphic features associated with the transition (transfer zone, Chapin and Cather, 1994) from the San Luis to Upper Arkansas segments of the Rio Grande rift.

Throughout the publication, needed references to map locations are by abbreviations of the 7.5' quadrangle names, as listed on figure 3; for example, the Bonanza quadrangle is referenced as BZ. 
Geographic coordinates for 2010 and more recent samples are by GPS, referenced to the 1983 North American Datum used on the U.S. Geological Survey (USGS) topographic maps for the region; older samples were located less precisely from NAD27-datum field sheets. Coordinates (GPS) are also noted for some critical interpretive locations. Some unit descriptions, age determinations, and geologic interpretations are based partly on features from adjacent quadrangles to the south or west (Lipman, 2006, 2012); these are also referenced by quadrangle abbreviations where appropriate.

As in other recent reports for the Bonanza region (Lipman and others, 2013, 2015), rock names are used in general accord with the IUGS classification system (Le Bas and others, 1986); in particular, the term "dacite" is used for rocks designated latite or quartz latite in some prior publications. Volcanic rocks in the Bonanza region constitute a high-K assemblage that is transitional between subalkaline and alkaline suites, similar to those throughout the SRMVF (fig. 6, sheet 2). For simplicity and continuity with previous usage, such modifiers as "highK" or "trachy" are omitted from most rock names. Names, divided on the basis of percent $\mathrm{SiO}_{2}$, are $<52$, basalt; 52-57, basaltic andesite; 57-62, andesite; 62-66, dacite; 66-70, silicic dacite (formerly quartz latite); 70-75, rhyolite; and $>75$, silicic rhyolite (all compositions for bulk-rock analyses recalculated to reported summations volatile-free, all $\mathrm{FeO}$ as $\mathrm{Fe}_{2} \mathrm{O}_{3}$ ).

Other than obvious xenocrysts, the megascopically visible crystal cargos of volcanic rocks are referenced as phenocrysts in unit descriptions, without necessarily implying equilibrium with compositions represented by the groundmass matrix. Many Bonanza rocks display textural and other evidence of disequilibria among phases in the crystal cargo and between crystals and groundmass compositions. Total phenocryst content tends to increase with $\mathrm{SiO}_{2}$, from andesite to dacite; plagioclase is the most abundant, accompanied by clinopyroxene and (or) hornblende in andesite. Biotite appears in silicic andesite and is the primary mafic phenocryst in dacites. Coarsely porphyritic plagioclase andesite is a distinctive lava type that is transitional in composition to mafic dacite. Sanidine is present in some silicic dacites and many rhyolites. Rhyolites tend to be crystal poor $(<10 \%)$, everywhere containing plagioclase, quartz, and sparse biotite. Phenocryst assemblages also distinguish many of the major ignimbrite sheets (table 2). Such descriptive distinctions, based on chemistry and phenocrysts, tend to obscure the gradational textures and compositions among the volcanic rocks. Uncertainties in hand-lens-based field determinations have likely led to local inconsistencies in map nomenclature, especially for andesitic and dacitic lavas, which were not mapped or subdivided as rigorously as the more silicic lavas and ignimbrites.

Cited chemical and petrographic data include about 280 new major-oxide and trace-element analyses for samples from the map area, determined by X-ray fluorescence methods at the Geoanalytical Lab, Washington State University (tables 3, 4), supplemented by data for regional units (Lipman, 2006, 2012). Sample selection for analytical work was complicated within Bonanza caldera, due to widespread propylitic metamorphism of deeply buried volcanic rocks, along with local acid-sulfate hydrothermal alteration and supergene leaching of disseminated pyrite. Accordingly, wherever possible, units were sampled from outflow areas beyond the caldera. Because most ignimbrites are densely welded, most analyses are for bulk samples; only a few localities of dacitic Bonanza Tuff contain pumice lenses sufficiently large to sample and analyze separately (noted on table 4). During preparation for analyses, bulk ignimbrite samples were coarse-crushed, and any discernable lithic fragments were discarded. A few obviously anomalous samples with suspect compositions (marked in red on table 5) were omitted from plots of chemical data.

Sanidine compositions (Lipman, unpub. data, 2000-2011), determined by routine electron-microprobe analysis (methods similar to those of Lipman and Weston, 2001), have also provided useful discriminants to test map correlations among some ignimbrite sheets as well as providing important information on processes of magmatic evolution. Mineral-chemical data for other phenocrysts (biotite, augite) show less variation among the many San Juan ignimbrites.

Critical to many interpretations presented here are the large array of high-precision ${ }^{40} \mathrm{Ar} /{ }^{39} \mathrm{Ar}$ age determinations (130 localities; in total, 138 mineral and groundmass ages; tables 5,6 ) for volcanic rocks in the Bonanza region (Lipman and others, 2015), including some published previously (McIntosh and Chapin, 2004; Lipman and McIntosh, 2008). All ages were determined at the New Mexico Geochronology Research Laboratory by methods similar to those described in McIntosh and Chapin (2004); additional details on sample preparation and irradiation, instrumentation, analytical parameters, and age calculations are reported by Lipman and others (2015). A singledetector MAP 215-50 was used to determine isotopic ratios prior to 2012. High-precision age determinations with improved precision were obtained for samples analyzed with the multicollector Argus VI mass spectrometer, starting in 2012. All new and previously published ages are calibrated to Fish Canyon Tuff (sanidine) at 28.02 Ma, for consistency with prior reports. All results are presented with $2 \sigma$ analytical uncertainty $(95 \%$ confidence interval). Interpreted preferred ages (table 3; fig. 7, sheet 2) are influenced by stratigraphic relations, supplemented by additional age determinations from beyond the map area; interpretive problems with ages for some units are discussed by Lipman and McIntosh (2008). Age results for sites within the Bonanza map area (81 samples) are plotted on the map.

Especially useful have been single-crystal laser-fusion ages on sanidine phenocrysts, obtained wherever this phase was present. Xenocrysts, sanidines with anomalously low radiogenic yields, and plagioclase crystals were excluded from weightedmean age calculations. Pooled sanidine ages for multiple sites from a single unit are listed as weighted means, with uncertainties as the standard error $\left(\mathrm{S}_{\mathrm{e}}\right)$.

Additional determinations are multi-crystal step-heating ages for biotite and hornblende phenocrysts, K-feldspar from some granitoid rocks, and groundmass concentrates from lavas lacking datable phenocrysts. For the step-heated samples, plateau ages are calculated when the age spectrum contains three or more contiguous steps that comprise $>50$ percent of the ${ }^{39} \mathrm{Ar}$ released and the steps overlap at 2-sigma (Fleck and others, 1977). Ages were calculated using the inverse isochron for samples that contained excess ${ }^{40} \mathrm{Ar}\left({ }^{40} \mathrm{Ar} /{ }^{36} \mathrm{Ar}>295.5\right.$; Nier, 1950). Many of the isochron ages agree, within $2 \sigma$ analytical uncertainty, with plateau or integrated ages for the same sample, but some are younger. Excess ${ }^{40} \mathrm{Ar}$ is especially common in the intrusive samples from 
Bonanza, probably reflecting a volatile component released from the upper-crustal Proterozoic wall rocks when heated by the growing subvolcanic magma bodies. The isothermal duplicate step-heating technique was used to remove excess ${ }^{40} \mathrm{Ar}$ from fluid inclusions in K-feldspar (Harrison and others, 1994). High-temperature steps also yielded anomalously old ages, likely related to excess ${ }^{40} \mathrm{Ar}$ in the largest domains (Foster and others, 1990). Plutonic K-feldspar from Questa (Zimmerer and McIntosh, 2012a) and Mount Aetna calderas (Zimmerer and McIntosh, 2012b), similarly exposed caldera systems in the SRMVF, also contains significant excess ${ }^{40} \mathrm{Ar}$.

Some step-heating analyses for biotite, hornblende, and groundmass concentrates yielded discordant spectra interpreted to reflect a combination of minor alteration of interstitial glass and ${ }^{39} \mathrm{Ar}$ recoil related to neutron radiation. Results are reported as integrated (or total-gas) ages if the spectrum fails to meet the criteria for a plateau age and the inverse isochron does not display a coherent array of data. Particularly problematic have been anomalously young groundmass ages from some fine-grained intermediate-composition lavas that lack datable phenocryst phases. Several discordant spectra contain significantly young low-temperature steps that increase in age during the first $\sim 10$ 20 percent of the ${ }^{39} \mathrm{Ar}$ released. Despite petrographic screening to avoid glassy matrix material, the young ages probably reflect ${ }^{40} \mathrm{Ar}$ loss from low retentive sites, such as poorly crystallized or otherwise altered interstitial sites where potassium was concentrated. Inclusion of these young, low-temperature steps commonly yields integrated ages with large uncertainties and, in some cases, ages that conflict with the established stratigraphy.

Cited paleomagnetic-pole directions for the San Juan rocks are from published sources (Tanaka and Kono, 1973; Diehl and others, 1974; Rosenbaum and others, 1987; Lipman and McIntosh, 2008).

In addition to the data summarized in the pamphlet, complete analytical results for the new ${ }^{40} \mathrm{Ar} /{ }^{39} \mathrm{Ar}$ determinations and whole-rock chemistry of volcanic units present in the northeastern San Juan region are included in tables 5 and 6 at https://doi. org/10.3133/sim3394. An extensive online photographic essay (140 annotated images) depicting major rock units and volcanic features of the Bonanza map area is also available at the web site; all photographs are by P.W. Lipman.

\section{Regional Framework of the Southern Rocky Mountain Volcanic Field}

Middle Tertiary volcanic deposits once were continuous across much of the Colorado Rocky Mountains and into northern New Mexico (fig. 1), constituting a composite Southern Rocky Mountain volcanic field (SRMVF), for which the San Juan region is the largest erosional remnant (Steven, 1975; Lipman, 2007). Subareas of the SRMVF, dismembered by subsequent extensional tectonism and erosion, have commonly been described misleadingly as multiple separate volcanic fields (San Juan, Sawatch, Thirtynine Mile, Latir, West Elk, Central Colorado) rather than as time-space transgressive magmatic foci within a large composite field.
Activity in the SRMVF peaked between 37 and $26 \mathrm{Ma}$ (McIntosh and Chapin, 2004; Lipman, 2007; Lipman and McIntosh, 2008). Dominantly intermediate-composition lavas and breccias (andesite-dacite) erupted from widely scattered central volcanoes were characteristic early phases of SRMVF activity. Major volcanic foci, initially established by clustered stratocones, became eruption sites for about 28 caldera-associated ignimbrites of more silicic compositions (table 1; fig. 8, sheet 2 ), in response to increased magmatic input at these sites. Composite volumes of the early-intermediate volcanoes are large; in the San Juan region stratigraphic sequences commonly are more than a kilometer thick, and total volume, estimated at 25,000 $\mathrm{km}^{3}$ (Lipman and others, 1970), is nearly twice that of the latererupted ignimbrites.

The original areal extent of the overall SRMVF appears to have exceeded $100,000 \mathrm{~km}^{2}$, with a total volume of volcanic deposits estimated to be greater than $60,000 \mathrm{~km}^{3}$ (Lipman, 2007; Lipman and Bachmann, 2015). Peak magmatic volumes in the SRMVF, associated with ignimbrite eruptions, define a general (if imperfect) progression (fig. 8) from early eruptions along the trend of the Sawatch Range in central Colorado (37-34 Ma; McIntosh and Chapin, 2004), southward into the San Juan region (33-27 Ma; Lipman and others, 1970), and later to the 25-Ma Latir-Questa magmatic center in northern New Mexico (Lipman, 1988; Johnson and others, 1989) and the 23-Ma Lake City caldera in the far western San Juan Mountains (Lipman, 1976a; Bove and others, 2001). The SRMVF is one of many loci of Tertiary volcanic activity - including the Sierra Madre Occidental, Trans-Pecos, Mogollon-Datil, Absaroka, Challis, and Lowland Creek fields - that developed along the eastern Cordilleran margin of the North American plate, probably in a complex response to changing subduction dynamics along the western plate boundary (Lipman and others, 1971).

\section{Paleotopography and Structure}

Middle Tertiary volcanic rocks of the northeastern San Juan Mountains lie along the broad boundary between Precambrian-cored uplifts of the Southern Rocky Mountains, which formed by contraction during low-angle plate subduction in Late Cretaceous and early Tertiary, and less-deformed Paleozoic and Mesozoic sedimentary rocks along the northeast flank of the Colorado Plateau. These differences in geologic setting exerted important controls on depositional, structural, and morphologic evolution during middle Tertiary volcanism. To the south and west in the San Juan region, gently dipping Mesozoic sedimentary rocks semi-conformably underlie the volcanic sequence, and the ignimbrite sheets form a stratified plateau, interrupted by local structural complexities associated with caldera and central-volcano constructs. The original middle Tertiary volcanic terrain was much like the Altiplano of the central Andes, because voluminous eruptions buried and subdued most of the pre-existing topography.

In contrast, volcanic accumulations in the northeastern San Juan region lap onto rugged paleotopography associated with the Late Cretaceous to early Tertiary (Laramide) uplifts of the Southern Rocky Mountains. Large paleovalleys, which developed during erosion of the early Tertiary uplifts and during the 
growth of central volcanoes prior to large ignimbrite eruptions, strongly influenced the distribution of subsequently emplaced volcanic deposits (for example, Chapin and Lowell, 1979; Steven and others, 1995). Some major San Juan paleovalleys survived the entire period of volcanism, and many presentday drainages are directly inherited from the middle Tertiary landscape, leading to the fieldwork expression "once a valley, always a valley." Especially conspicuous within the map area is the course of lower Saguache Creek, which empties into the San Luis Valley at the town of Saguache (fig. 4). This modern drainage coincides with a broad paleovalley between Oligocene stratocones to the north and south. All the major Oligocene ignimbrites of the region were deposited preferentially along this paleovalley. Similarly, the present-day basin of Cochetopa Park is inherited morphology from an Oligocene caldera.

Exposed pre-Tertiary rocks also provide useful information on paleotopography at the inception of volcanism and subsequent events. Notably, Precambrian basement and small windows of Paleozoic sedimentary rocks, but no Mesozoic rocks, are exposed around margins of Marshall and Bonanza calderas, showing that these calderas formed on a prevolcanic highland, probably a southern continuation of the Sawatch Range uplift of Late Cretaceous age. Farther west, gently dipping Mesozoic sedimentary rocks are widely present beneath the volcanic cover (Tweto, 1979; Lipman, 2012), reflecting proximity to the Colorado Plateau. Widespread absence of early Tertiary sedimentary deposits along the unconformity at the base of the volcanic sequence in the map area, such as preserved farther south and west in the San Juan region (Blanco Basin Formation, Telluride Conglomerate), is further evidence that the prevolcanic paleosurface of the Bonanza region stood topographically high and was primarily a region of erosion rather than deposition. Meter-size boulders of Precambrian rocks in the sparsely preserved early conglomerates (unit Tev) that locally underlie Tertiary lavas along Poncha Creek and upper Marshall Creek document the existence of rugged late Eocene paleorelief on the local Laramide-age uplift (paleo-Sawatch Range).

The prevolcanic highland, formed during Laramide compression and uplift, as documented by absence of the Mesozoic strata, coincides approximately with southern parts of the present-day Sawatch Range, even though the Cenozoic structure and modern topography were further greatly modified by graben formation along the upper Arkansas and San Luis valleys during extensional growth of the Rio Grande rift. As a rough approximation, the northeastern San Juan Mountains, north of the Saguache Valley, contain the southern termination of the west-tilted Sawatch Range horst and the structurally complex transition (transfer zone) into the east-tilted west flank of the San Luis Valley farther to the south (fig. 1). The deep subsidence structures of Bonanza and Marshall calderas punctuate the southward termination of the Sawatch Range horst. Despite this caldera overprint, at present erosion levels paleohills of Precambrian rocks protrude through the volcanic cover at elevations that rise northward from the Saguache Valley toward the Sawatch Range, but basement outcrops are absent southward along the west flank of the Rio Grande rift until reappearing beneath distal volcanic rocks of the SRMVF, $130 \mathrm{~km}$ to the south in the Tusas Mountains of northern New Mexico.
Due to greater paleorelief, the stratigraphic record of sequential eruptions is less complete in the northeastern San Juan Mountains than to the southwest. Many volcanic deposits in the northeast sector accumulated in deep valleys, which were incompletely filled and then re-excavated by erosion between successive eruptions. The regional ignimbrites, rather than forming a stratified plateau, can be preserved in inverted topographic order, with earlier tuff sheets capping ridges and younger units exposed at lower levels within paleovalleys. In many places, welded tuffs are exposed as isolated scabs, unconformably against slopes of paleovalleys, without stratigraphic continuity between sequential deposits. Frequent miscorrelations of ignimbrite units in previously mapped local areas of the northeastern San Juan region resulted from such complexities, as well as from limited exposures due to forest cover, incomplete knowledge of the regional eruptive sequence, and inadequate recognition of petrographic distinctions among tuff sheets.

An exceptionally clear example of paleovalley complexity on a geologically brief time scale is provided by features along Silver and Poncha Creeks in the north-central map area (MO). The stratigraphically lowermost rocks are andesite lavas of the Conejos Formation, exposed at elevations as low as $8,600 \mathrm{ft}$ $(2,620 \mathrm{~m})$. These flows are of uncertain age but perhaps predate the 34-Ma Thorn Ranch Tuff. They are preserved to thicknesses of at least $300 \mathrm{~m}$, variably banked or faulted to the north against the paleohigh of present-day Mount Ouray (13,971 ft; 4,258 m). A deep paleovalley was eroded in the andesite sequence prior to eruption of the Bonanza Tuff, which is preserved in tiny outcrops of basal vitrophyre and partly welded glassy dacitic tuff at water level along Silver Creek (lat $38^{\circ} 23.96^{\prime}$ N., long $106^{\circ} 07.74^{\prime}$ W.; identification confirmed by petrography and isotopic age, sample 09L-3, table 5). Most of the Bonanza Tuff originally deposited in paleo-Silver Creek was eroded prior to eruption of crystal-poor rhyolitic lavas. These lavas have a pooled age of $33.04 \pm 0.05 \mathrm{Ma}$, only marginally younger than the ignimbrite, and are correlated with the postcaldera Porphyry Peak Rhyolite. The rhyolite lavas banked against both sides of the ridge between paleo-Silver and paleo-Poncha Creeks, in places still capping the ridge crest to a thickness of at least $250 \mathrm{~m}$, as constrained by present-day erosional remnants. The rhyolites in turn were erosionally excavated along the same paleovalleys, which were then refilled to a thickness of at least $325 \mathrm{~m}$ (top eroded) by a sequence of sanidinebearing dacite lavas of the Bonanza caldera cycle, the uppermost of which have a weighted mean age of $32.76 \pm 0.02$ Ma. Presentday Silver Creek closely mimics the Oligocene drainage axis: "Once a valley, always a valley."

Erosional postvolcanic dissection to depths of as much as several kilometers in the San Juan region has exposed diverse features of thick intracaldera ignimbrite and associated calderafill deposits that accumulated within concurrently subsiding caldera structures. The calderas display a variety of postcollapse structures, and caldera-forming events produced complex fault geometries that localized late mineralization, especially at Bonanza, Platoro, Creede, and several western San Juan calderas. Creede and Cochetopa Park, as the youngest calderas in the central San Juan region, remain morphologically well preserved due to fill by weakly indurated volcaniclastic sedimentary deposits that have been exhumed by uplift and erosion 
only relatively recently. Most other San Juan calderas have been severely eroded, variably exposing deep internal structures, and their identification has depended on detailed geologic mapping.

\section{Early Northern Volcanism along the Sawatch Trend}

Eruptions beginning in the northern SRMVF at least as early as $38 \mathrm{Ma}$, as recorded by andesitic lavas and breccias in the Thirtynine Mile area (Epis and Chapin, 1974; McIntosh and Chapin, 2004), are precursors to ignimbrite volcanism in the Bonanza region. Caldera sources for all early-erupted (37-33 Ma) large ignimbrites of the SRMVF (table 1) form a northnorthwesterly alignment along the crest of the present-day Sawatch Range (fig. 1), but preserved exposures of the outflow tuff sheets are limited, especially west of the present-day Continental Divide. The stratigraphy, regional distribution, and eruptive history of these ignimbrites remain incompletely documented; main features are summarized briefly here.

The first major regional ignimbrite was the far-traveled Wall Mountain Tuff (Chapin and Lowell, 1979), a relatively crystal rich rhyolite (table 2). It erupted at $36.9 \mathrm{Ma}$, probably from a now completely eroded caldera above the $25-\mathrm{x} 35-\mathrm{km}$ Mount Princeton batholith (fig. 1; table 1), the largest Tertiary intrusion in the Rocky Mountains (Shannon, 1988; Johnson and others, 1989; Lipman, 2007; Lipman and Bachmann, 2015; but see alternative interpretation in Mills and Coleman, 2013). Distal Wall Mountain Tuff spread eastward more than $150 \mathrm{~km}$ from its source onto the High Plains between Denver and Colorado Springs (Chapin and Lowell, 1979). The only known preserved localities for this ignimbrite west of the Sawatch Range are local valley-fill deposits northwest of Cochetopa Park, 80-90 $\mathrm{km}$ southwest of Mount Princeton (Lipman and McIntosh, 2008; Lipman, 2012).

North of the Mount Princeton batholith is the spectacularly exposed Grizzly Peak caldera and associated intracaldera tuff (Fridrich and Mahood, 1987; Fridrich and others, 1998), active at 34.3 Ma (McIntosh and Chapin, 2004). Nested within the southern margin of the Princeton batholith is the slightly younger Mount Aetna caldera (Shannon, 1988; Toulmin and Hammarstrom, 1990), source of the 34.1-Ma Badger Creek Tuff (Epis and Chapin, 1974; Shannon and others, 1987) and associated intrusions (34.1-29.6 Ma; McIntosh and Chapin, 2004; Zimmerer and McIntosh, 2012b; Mills and Coleman, 2013). Small remnants of Badger Creek Tuff (Tbc) are preserved along northern margins of the Bonanza map area. Another Sawatch-trend center is Marshall caldera in the northwest corner of the map area (figs. 2, 3), source of the 34-Ma Thorn Ranch Tuff (unit Ttr) that is preserved mainly in the Thirtynine Mile region east of the Rio Grande rift (Epis and Chapin, 1974; McIntosh and Chapin, 2004).

During this study, it also became clear that two of the previously described and named tuffs in the Thirtynine Mile region, the tuff of Stirrup Ranch and East Gulch Tuff of Epis and Chapin (1974), are not discrete regional ignimbrite deposits, thereby increasing the recurrence intervals between early SRMVF eruptions (fig. 8). Rocks previously mapped as Stirrup Ranch Tuff are now recognized to be a local sheet of coarse volcaniclastic breccia, consisting of randomly oriented clast-supported angular blocks. All the blocks are densely welded Wall Mountain Tuff, as identified by similar rock chemistry, phenocryst populations, and ${ }^{40} \mathrm{Ar} /{ }^{39} \mathrm{Ar}$ ages (Lipman and others, 2015). The absence of bedding and random orientation of large clasts (to several meters) in this unit are closely comparable to some monolithologic welded-tuff breccias in central Nevada that have been interpreted as products of catastrophic dam-burst-type floods resulting from short-term blockage of paleovalleys by volcanic rocks or landslides (Henry, 2008), and a similar origin seems likely for the Stirrup Ranch deposit. The previously described East Gulch Tuff is here interpreted as the non-welded to weakly welded basal rhyolitic zone of the Thorn Ranch Tuff, as clearly exposed at several sections, including sites sampled for geochronologic and paleomagnetic determinations (McIntosh and Chapin, 2004). The transition upward into densely welded interior Thorn Ranch Tuff is gradational, and the isotopic ages and paleomagnetic poles of these two tuff bodies are indistinguishable.

The Bonanza region, including the source of the Bonanza Tuff at 33.12 Ma (photo 9), geographically lies within the San Juan Mountains (fig. 2) but could equally be considered the youngest and southernmost caldera along the Sawatch trend (Varga and Smith, 1984; McIntosh and Chapin, 2004). Bonanza and Marshall calderas mark the initial progression of ignimbrite eruptions to the southwest into the core of the San Juan volcanic region (fig. 2).

\section{San Juan Volcanic Region}

The San Juan Mountains are the largest erosional remnant of the SRMVF (fig. 1). Preserved volcanic rocks occupy an area of more than $25,000 \mathrm{~km}^{2}$ and have a volume of about 40,000 $\mathrm{km}^{3}$. They cover a varied basement of Precambrian to early Tertiary rocks along the uplifted and eroded west margin of the Late Cretaceous to early Tertiary (Laramide) uplifts of the Southern Rocky Mountains and adjoining portions of the San Juan Basin on the eastern Colorado Plateau (fig. 1). As middle Tertiary volcanism migrated southward from the Sawatch Range trend (fig. 8 , sheet 2), widely scattered intermediate-composition centers (dominantly andesite, lesser dacite, minor rhyolite) erupted lavas and flanking volcaniclastic breccias in the San Juan region starting at 35-34 Ma (Lipman and others, 1970; Lipman and McIntosh, 2008). These rocks, which constitute about two-thirds the volume of the preserved volcanic assemblage, are widely overlain by compositionally diverse large-volume ignimbrites and associated caldera collapses (Steven and Lipman, 1976).

After ignimbrite eruptions from Marshall and Bonanza calderas at 33.9 and 33.1 Ma in the northeastern San Juan Mountains (figs. 8, 9), magmatic activity migrated farther southwest with eruption of the Saguache Creek Tuff (unit Tsc) from North Pass caldera at 32.2 Ma (Lipman and McIntosh, 2008; Lipman, 2012; Lipman and others, 2013). Ignimbrite eruptions gradually became widespread: starting in the southeastern San Juan region at 30.1 Ma (Black Mountain Tuff, unit Ttb, Platoro caldera complex), followed shortly by eruptions mainly of crystal-poor rhyolite from western San Juan calderas (Steven and Lipman, 1976; Lipman and others, 1996; Bove and others, 2001). Ignimbrite 
activity progressively focused in the central San Juan Mountains, leading to eruption of the enormous Fish Canyon Tuff (unit Tfc, $5,000 \mathrm{~km}^{3}$ of monotonously uniform crystal-rich dacite) and collapse of the 35- x 75-km La Garita caldera at 28.0 Ma (Lipman, 2000, 2006; Bachmann and others, 2002). In the central San Juan Mountains, seven major eruptions of compositionally diverse ignimbrite, with volumes of $100-1,000 \mathrm{~km}^{3}$, erupted during a 1.1m.y. interval from calderas nested within La Garita caldera (fig. 2). At each caldera, initial post-ignimbrite volcanism consisted of intermediate-composition to silicic lavas and breccias that variably filled the caldera depressions, some to overflowing. At about $26 \mathrm{Ma}$, volcanism shifted to a bimodal assemblage dominated by trachybasalt and silicic rhyolite, concurrent with the inception of regional extension along the Rio Grande rift.

The eruptive and subsidence history of the most northerly of the central San Juan systems, the San Luis complex from which three regional ignimbrite sheets were erupted in rapid succession at 26.9 Ma (Lipman and McIntosh, 2008), is closely intertwined with development of Cochetopa Park caldera (figs. 2, 4). In particular, the final large eruption, which produced the Nelson Mountain Tuff, appears to have triggered subsidence both at the eruption site in the San Luis complex and at Cochetopa Park. Stratigraphic and other interpretive problems that emerged during study of the Cochetopa Park area led directly to the need for improved understanding of the immediately adjacent Bonanza region.

\section{Geologic Setting of Bonanza Caldera}

The Bonanza region is more structurally complex than most other sectors of the San Juan Mountains because (1) deep erosion has exposed prevolcanic structure and paleotopography in Paleozoic and Proterozoic rocks beneath the thick Tertiary volcanic cover of the SRMVF, (2) ring-subsidence faults and uplift structures of the strongly resurgent Bonanza caldera are exposed at deep levels down to the floor of this geometrically complex caldera, (3) widespread alteration and vein mineralization obscures stratigraphy and structure in the Bonanza mining district, and (4) postvolcanic extension has formed normal faults, stratal tilting, and accommodation-zone structures at the junction between the San Luis Valley and Upper Arkansas segments of the Rio Grande rift. Several unconformities along flanks of large paleovalleys in the Bonanza region previously have been shown as large faults on regional maps (for example, Tweto, 1979). In this study, faults have been depicted conservatively, only where evidence for displacement is clear; some unmapped structures undoubtedly exist in places where field relations are incompletely compelling.

\section{Pre-Tertiary Rocks in the Bonanza Region}

Proterozoic and Paleozoic rocks that crop out widely around eastern and northern margins of the Bonanza map area define a rugged paleosurface of highlands and paleovalleys, which were recurrently partially buried and re-excavated during middle Tertiary volcanism. The Proterozoic rocks include large areas of coarsely porphyritic granodiorite (unit p€g; photo $3.1 A$ ), intruded into diverse metasedimentary and metavolcanic country rocks (unit p€m; photo $3.1 B$ ) of quartzo-feldspathic gneiss, schist, meta-arkose, and amphibolite. A sizable area of surprisingly uniform aplite (unit p€a) is exposed in the Alder Creek drainage (WH).

Paleozoic sedimentary rocks that are preserved between Precambrian basement and overlying Tertiary volcanic rocks provide important evidence for pre-volcanic and synvolcanic structural events. Lower Paleozoic strata (photo 3.2) are dominantly marine carbonate deposits; these have long been subdivided into multiple formations (Burbank, 1932; Cappa and Wallace, 2007) that provide exceptional structural control. Upper Paleozoic strata (photo 3.3) are continental clastic deposits that record concordant uplift (Ancestral Rocky Mountains) and subsequent erosion. Although the Upper Paleozoic rocks are a thick sequence, distinctive subunits are largely lacking; detailed subdivision has not been possible, other than distinction between a basal quartz-dominated sandstone (Kerber Formation) and diverse overlying shaley and arkosic sedimentary units (Sharpsdale Formation).

The pre-Tertiary rocks were further deformed, uplifted, and deeply eroded during Laramide compressional growth of the Rocky Mountains in the Late Cretaceous and early Tertiary, and the middle Tertiary volcanic rocks were deposited on a rugged paleosurface carved mainly into Precambrian rocks with only local remnants of the Paleozoic sequence. The largest area of exposed Paleozoic strata, on both sides of lower Kerber Creek (GG), define a central south-plunging anticline and an eastwest-trending zone of faulting (fig. 10, sheet 2). These features have previously been interpreted as Laramide structures related to Cretaceous-Eocene compression and uplift (Burbank, 1932, p. 37-42; Cappa and Wallace, 2007, p. 38, 45), but the new mapping suggests that these structures largely resulted from subsidence and subsequent resurgence of Bonanza caldera. In contrast, smaller areas of lithologically similar Paleozoic strata, along upper Marshall and Poncha Creeks in the northwest margin of the map area, appear to define structures that mainly formed prior to middle Tertiary volcanism.

\section{Early Lavas and Intrusions (35-33 Ma)}

As elsewhere in the San Juan region, ignimbrite sheets and other rocks associated with calderas in the Bonanza region overlie thick lava sequences that erupted from large central volcanoes (figs. 4,10 ). Sections of the early lavas as much as $2.3 \mathrm{~km}$ thick have been penetrated by petroleum exploration drilling in the San Luis Valley southeast of Bonanza (Gries, 1985; Brister and Gries, 1994). In comparison with the early-intermediate assemblage farther south and west in the San Juan Mountains, lava thicknesses in the northeastern area are much more variable due to rugged prevolcanic paleotopography. The assemblage in the Bonanza region also contains higher proportions of proximal lavas and breccias relative to distal laharic conglomerates and other volcaniclastic rocks, and dacite and rhyolite are more voluminous components of the dominantly andesitic lava assemblage. 
Rocks of these central volcanoes are broadly correlative with the regional Conejos Formation elsewhere in the San Juan region (Lipman and others, 1970; Colucci and others, 1991), but several early-erupted tuff sheets are interstratified with lavas of ages that predate all ignimbrite units from farther south and west in the San Juan Mountains (fig. 9). These tuffs, including several from caldera centers along the Sawatch trend, together with datable sanidine phenocrysts in some silicic lavas help define the eruptive history of early lavas in more detail than possible elsewhere in the region. The lavas that are interstratified with the early tuff sheets, as well as andesitic and dacitic lavas that ponded within ignimbrite calderas throughout the San Juan region, are compositionally indistinguishable from earliererupted lavas of the Conejos assemblage. These lavas, described as late phases of individual caldera cycles, document eruptive and compositional continuity during growth of the SRMVF.

On a regional scale, total thickness and volume of the early lavas are far greater than for the ignimbrite sheets. In the northeastern San Juan region, lavas are locally exposed over a vertical range of more than 1,000 m from along Saguache Creek to the Continental Divide, although thicknesses are highly variable due to local paleotopography and erosion, broadly decreasing northward toward the Gunnison River valley and eastward toward the San Luis Valley segment of the Rio Grande rift. Paleohills of basement rocks projecting through the volcanic cover are more common than farther to the south and west in the San Juan region. Within the Bonanza map area, the early lavas thin against prevolcanic paleohills; in some paleovalleys, especially along upper Jacks Creek and its tributaries (LMNE), Bonanza Tuff was deposited directly against Proterozoic granodiorite. Along the major paleovalley followed by present-day Saguache Creek, only about $50 \mathrm{~m}$ of early andesite lava intervenes between dacitic Bonanza Tuff and the underlying metamorphic basement west of the mouth of Dry Gulch (LMNE).

Even more variable thicknesses and volumes of pre-ignimbrite lavas may have characterized the older caldera systems to the north. For example, the Thorn Ranch Tuff (unit Ttr), erupted from Marshall caldera just northwest of Bonanza, contains a preponderance of Proterozoic lithic fragments relative to Tertiary volcanic clasts, suggesting limited volcanic cover in this area at the time of ignimbrite eruption and caldera formation. Thick middle Tertiary andesitic sequences are preserved in the Thirtynine Mile region and as far north as Buffalo Peak (fig. 1), but the deeper erosional levels and lack of preserved Tertiary volcanic rocks beyond subsided caldera blocks in the Sawatch Range preclude reliable thickness estimates of earlier lavas at sites of the earliest ignimbrite centers.

Parts of at least six eruptive centers for pre-Bonanza lavas, all of which are regionally equivalent to the rocks of the Conejos Formation farther southwest, lie within the Bonanza map area, and others are present farther west, in the CochetopaNorth Pass area (Lipman, 2012). These centers probably include the earliest eruptions in the San Juan region, with activity becoming younger to the west and south:

1. Jacks Creek volcano (photo 4): The earliest well-defined Conejos volcano in the map area, centered in the Jacks Creek drainage (LMNE), contains well-exposed radial dikes, a composite central-vent intrusion of fine-grained granodiorite, and porphyritic rhyolite surrounded by outward-dipping andesitic lavas (fig. 10). Lavas and intrusions of the Jacks Creek volcano have yielded ${ }^{40} \mathrm{Ar} /{ }^{39} \mathrm{Ar}$ determinations for lavas and intrusions that are mostly in the range of 35-34 Ma (tables 5, 6), among the oldest dated rocks from the San Juan region. The Jacks Creek volcano was deeply eroded prior to eruptions from Bonanza caldera, and some dikes at the core of this center are capped by small exposures of preserved Bonanza Tuff.

2. Northern Conejos lavas: Largely undated andesitic to rhyolitic lavas along Poncha Creek, at the north margin of the map area (MO), are overlain by small erosional remnants of the 34-Ma Thorn Ranch Tuff (unit Ttr). Biotite from one dacite lava along Poncha Creek yielded an age of $35.04 \pm 0.11 \mathrm{Ma}$ and must accordingly be related to eruptive centers roughly similar in age to the Jacks Creek volcano and to the large 34.5-Ma Needle Creek eruptive center west of the map area (Lipman, 2012). These rocks must have erupted from several sources, some now likely concealed beneath Marshall and Bonanza calderas or sedimentary fill of the San Luis Valley. A small intrusion of texturally transitional andesite to fine-grained granodiorite (unit Tia), just west of O'Haver Lake (MO), probably marks one eruptive center; it intrudes, or is faulted against, a dacite lava having a biotite age of $33.46 \pm 0.11 \mathrm{Ma}$.

3. Lava fill of Marshall caldera: Voluminous andesitic and dacitic lavas that accumulated within Marshall caldera (eruptive source of the Thorn Ranch Tuff) were emplaced prior to the Bonanza Tuff, and thus their age is bracketed between 33.9 and 33.2 Ma. The locations of eruptive centers for these lavas are not well constrained. Although described as part of the Marshall cycle, these rocks are compositionally indistinguishable from Conejos lavas farther west in the region and would not be mapped separately were it not for the stratigraphic control provided by the Thorn Ranch Tuff.

4. Rawley volcanic complex (photo 5): A large stratocone or composite cluster of early Conejos-age volcanoes forms a present-day volcanic highland within which Bonanza caldera is centered (fig. 10). This dominantly andesitic lava sequence, previously designated the Rawley Andesite (Burbank, 1932; Varga and Smith, 1984), also includes varied dacite and rhyolite lavas that in places directly overlie the Protoerozoic basement or preserved areas of Paleozoic sedimentary rocks. Few of the Rawley lavas are suitable for dating, and none have thus far yielded ages older than the 34-Ma Thorn Ranch Tuff erupted from Marshall caldera, just to the northwest of the Bonanza caldera. No meaningful composition or age distinction has been possible between postcaldera lavas of Marshall caldera and precaldera Rawley lavas of the Bonanza center in parts of the map area, and some unit distinctions have been arbitrarily assigned based on local lithologic changes.

5. Sargents Mesa volcano: Thick remnants of an inadequately understood large andesite lava accumulation underlie Sargents Mesa along the Continental Divide, at the west margin of the map area $(\mathrm{CH})$ and farther west. At 
the periphery of this assemblage, some lavas are onlapped by Bonanza Tuff, but several samples from high in the central accumulation have yielded groundmass plateau ages that are analytically indistinguishable from the tuff. The near-horizontal roof zone of large high-level intrusion (at least $3.5 \mathrm{~km}$ across), composed of variably altered porphyritic dacite and fine-grained granodiorite, is exposed on the north side of Sargents Mesa just west of the map area (Lipman, 2012), along lower canyon slopes in upper Long Branch (SM). An unaltered dike offshoot of this body, which appears to constitute the intrusive core of the Sargents Mesa edifice, has yielded an isotopic age of about $33.0 \mathrm{Ma}$, even though the intrusion roof is at an elevation about as high as flanking remnants of the 33.12Ma Bonanza Tuff. The Sargents Mesa volcano may have grown as a high-standing edifice just prior to eruption of the Bonanza Tuff, possibly with some central eruptions and final assembly of the axial intrusion continuing later. The low-relief upland surfaces of Sargents Mesa (mainly west of the Bonanza map; Lipman, 2012) appear to be a paleoslope, from which all Bonanza Tuff has been erosionally stripped; tiny remnants of nonwelded crystal-poor rhyolite tuff (lat $38^{\circ} 17^{\prime}$ N., long $106^{\circ} 23.25^{\prime}$ W.) are younger $(32.8$ Ma; table 6) and may represent distal pyroclastic deposits associated with eruption of the Porphyry Peak Rhyolite or other postcaldera silicic lavas.

6. Tracy volcano (photo 6): South of the Saguache Valley, a thick lava pile centered along Tracy Canyon (SG, LG) marks the north flanks of another large central volcano of Conejos age, areally separate from the Bonanza locus but having roughly concurrent eruptive activity. The Tracy volcano contains a thick compositionally diverse sequence of lavas that dip outward from a central intrusion of fine-grained granodiorite and intergradational andesite; a spectacular array of dikes radiate outward on its eastern flank. Outflow Bonanza Tuff wedges within lavas from the Tracy center, above a sequence of dark andesite lavas but below capping lavas of porphyritic mafic dacite on Tracy Mountain (fig. 4, LG). Several early dacite and rhyolite lavas from deep in central parts of the Tracy volcano have yielded ages of about $33.5 \mathrm{Ma}$, and the highest andesite lava on Tracy Mountain has a groundmass age of 31.5 Ma. Farther west near Carnero Pass (LM, lat $37^{\circ} 57.73^{\prime}$ N., long $106^{\circ} 25.99^{\prime}$ W.), a petrographically unusual dacite lava high in this assemblage, containing sanidine phenocrysts as large as $2 \mathrm{~cm}$ across, yielded a ${ }^{40} \mathrm{Ar} /{ }^{39} \mathrm{Ar}$ age of $32.72 \pm 0.09 \mathrm{Ma}$.

\section{Thorn Ranch Tuff and Marshall Caldera Cycle (33.9 Ma)}

Eruption of the Thorn Ranch Tuff from the previously unmapped Marshall caldera (figs. 2, 4) was the most proximal antecedent to the ignimbrite from Bonanza caldera $0.8 \mathrm{~m}$.y. later, and features of this caldera provide the basic stratigraphic and morphologic framework for interpreting the younger volcanic activity (photo 7). The thick sequence of intermediate-composition lavas that filled Marshall caldera merge with precursor lavas of the Bonanza cycle, and Bonanza caldera caved away the southeast margin of the earlier caldera (photo 7.1A). Along with the slightly younger Saguache Creek Tuff (32.2 Ma; Lipman and McIntosh, 2008), these three major ignimbrite eruptions and associated calderas of the northeastern San Juan Mountains bracket a major geographic transition, from earlier SRMVF activity along the Sawatch Range trend into the locus of peak eruptive activity in the San Juan region (figs. 1, 8).

Probable presence of an ignimbrite caldera in upper Marshall Creek (PP) was initially inferred by Thomas Steven (written commun., 1986), based on his interpretation of a published geologic map in the Marshall Pass mining district (Olson, 1983). Olson's detailed map depicts a lithologic assemblage (welded tuff interleaved with volcanic breccia, overlain by tuffaceous lake-bed sedimentary deposits) similar to that within ignimbrite calderas elsewhere in the San Juan Mountains (Steven and Lipman, 1976). Subsequently, Gregory and McIntosh (1996), during study of fossil flora in lake-bed sediments of the Pitch-Pinnacle Formation (unit Tmp), dated the welded tuff in upper Marshall Creek, noted associated megabreccia of intracaldera type, and suggested that this assemblage might mark a caldera source for the 33.9-Ma Thorn Ranch Tuff (unit Ttr), an outflow rhyolitic ignimbrite preserved widely in the Thirtynine Mile area to the northeast (Epis and Chapin, 1974; McIntosh and Chapin, 2004).

This study confirms and augments these interpretations, providing the first geologic map coverage of Marshall caldera and associated volcanic units, including geochronologic and petrologic data for caldera-related rocks, and demonstrating that postcaldera eruptions from Marshall caldera were major precursors to inception of the Bonanza eruptive cycle. Although largely concealed beneath younger lavas and truncated by Bonanza caldera, Marshall caldera is the oldest ignimbrite source in the San Juan Mountains. Along a previously unrecognized margin of this caldera, a $>400$-m-thick section of intracaldera Thorn Ranch Tuff with no base exposed banks against Proterozoic wall rocks, as strikingly displayed at a geographic feature known as "The Gate" (fig. 10; photo 7.1B), east of Marshall Pass (BZ). This steep unconformity has been depicted on previous regional maps as a contact of andesite against Proterozoic rocks (Tweto and others, 1976; Cappa and Wallace, 2007), but densely welded lineated tuff dips parallel to contacts at The Gate and contains large Proterozoic clasts derived from the caldera wall (photos $7.2 A, B)$. Dips in the Thorn Ranch Tuff decrease, from locally near-vertical at the caldera wall to as low as $20-25^{\circ}$ at $100-200$ $\mathrm{m}$ distance from the contact. Exposed intracaldera Thorn Ranch Tuff includes alternations of crystal-rich dacite and crystal-poor rhyolite that have not been mapped or studied in detail.

The northern wall of Marshall caldera (photo 7.1A) is exposed continuously from The Gate northwestward into upper Marshall Creek (fig. 10), where it projects southward, roughly along Tank Seven Creek (KM) as constrained by exposed Proterozoic and Paleozoic rocks farther west. Its southwestern margin is concealed beneath caldera-filling lavas and younger volcanic rocks, but an east-west alignment of paleohills of Proterozoic rocks from Ward Gulch (LMNE) to upper Mill Gulch 
(KM) and parallel exposures of Bonanza and Saguache Creek Tuff preserved just to the north constrain the concealed southern limit of Marshall caldera (fig. 11, sheet 2). Southeastern parts of this caldera appear to have been deeply buried beneath late lavas and volcaniclastic rocks of this caldera cycle and younger lavas of the Rawley complex, then truncated by the younger Bonanza caldera. Based on these relations, the overall dimensions of Marshall caldera are estimated to be about $15 \times 20 \mathrm{~km}$, with a subsided area of at least $250 \mathrm{~km}^{2}$.

No postcollapse resurgence is evident at Marshall caldera, and much of its structure is concealed beneath lavas of andesite, dacite, and local rhyolite that overflowed the collapse area (photo 7.3). The earliest of the caldera-fill lavas, the large dacite dome at Sheep Mountain (photo 7.3A), directly overlies the intracaldera ignimbrite and has a sanidine ${ }^{40} \mathrm{Ar} /{ }^{39} \mathrm{Ar}$ age of $33.89 \pm 0.07 \mathrm{Ma}$, indistinguishably younger than the Thorn Ranch Tuff. The caldera is exposed at relatively shallow levels, revealing only upper parts of the intracaldera ignimbrite overlain by postcollapse-lava lavas. Exposed landslide megabreccia (photo 7.2C), in upper Marshall Creek (PP), is high in the intracaldera ignimbrite, directly overlain by caldera-fill andesite-lava lavas. This geometry suggests abrupt subsidence late during the eruption, after sustained slower subsidence during accumulation of the thick ignimbrite exposed at The Gate (photo 7.1B), which contains abundant fragments of Proterozoic rocks (photo 7.2B) as much as $0.5 \mathrm{~m}$ across but lacks discrete interleaved megabreccia lenses. Analogous late generation of collapse breccias is also well documented for the younger Creede caldera in the central San Juan region (Lipman, 2000).

The postcollapse lavas merge to the south and west with petrologically indistinguishable andesite and dacite of the Rawley volcanic complex (as old as $33.7 \mathrm{Ma}$ ) that are precursors to the Bonanza cycle. The postcollapse lavas of Marshall caldera also interfinger with lake-bed deposits of the Pitch-Pinnacle Formation (Olson, 1983; Gregory and McIntosh, 1996). This sedimentary assemblage is thickest beyond the northwest margin of Marshall caldera (photo 7.3B), in an embayment (PP) that appears to have been a broad paleovalley disrupted by calderaforming events and then occupied by a lake concurrently with eruption of caldera-filling lavas.

Small remnants of partly welded dacite ignimbrite, interpreted as proximal Thorn Ranch Tuff on the basis of ages and compositions (tables 3, 4, 5, 6) similar to the intracaldera accumulation and widespread outflow east of the Rio Grande rift, are preserved locally within the map area, east and northeast of Marshall caldera. The proximal outflow tuff is compositionally similar to more mafic parts of the compositionally variable intracaldera tuff but more mafic and crystal rich than the more distal eastern outflow ignimbrite. Such preferential proximal and intracaldera deposition of more mafic parts of compositionally diverse ignimbrites is common in the SRMVF and elsewhere (Lipman, 1984, 2007). The eastern outflow Thorn Ranch Tuff is a densely welded silicic rhyolite $\left(75-77 \% \mathrm{SiO}_{2}\right)$, characterized by common small fragments of Proterozoic rocks. Less-welded lower parts of the outflow Thorn Ranch Tuff were previously described as the East Gulch Tuff and interpreted as a separate underlying ignimbrite sheet (Epis and Chapin, 1974; McIntosh and Chapin, 2004), but this lower zone has a similar composition and isotopic age (mean of three sites, $33.89 \mathrm{Ma}$ ), and welding intensity increases gradationally upward into overlying more densely welded Thorn Ranch Tuff (Lipman and others, 2015).

Perplexingly, no outflow remnants of Thorn Ranch Tuff or any other ignimbrite sheet that could be related to Marshall caldera have been identified farther west or south in the northeastern San Juan Mountains, even though basal volcanic strata in contact with underlying Mesozoic and Proterozoic rocks are exposed widely (Lipman, 2012). Along Indian Creek (PP) at the northwest margin of Marshall caldera, sedimentary strata of the Pitch-Pinnacle Formation and interlayered lavas lap out against and overlie the just-older Badger Creek ignimbrite (34.1 Ma), without intervening Thorn Ranch Tuff. Farther west in the Needle Creek area (WB), lavas as old as 34.1 Ma are present low in volcanic sections capped by the 33.1-Ma Bonanza Tuff, but no older ignimbrites are present. Because of these limited exposures, the eruptive volume of the Thorn Ranch Tuff cannot be determined in detail, but the large inferred size of Marshall caldera $\left(>250 \mathrm{~km}^{2}\right)$, the presence of intracaldera tuff more than $400 \mathrm{~m}$ thick with no base exposed, and distribution of preserved outflow tuff at least $70 \mathrm{~km}$ east of the source caldera (McIntosh and Chapin, 2004, fig. 2D) all indicate a major ignimbrite eruption, estimated as greater than $500 \mathrm{~km}^{3}$.

Marshall caldera is eroded less deeply than Bonanza, without comagmatic intrusions, and only upper portions of the caldera-filling ignimbrite are exposed beneath widespread cover by postcaldera lavas. This geometry is consistent with Rio Grande rift-related regional westward tilting $\left(\sim 10-25^{\circ}\right)$ of a structural block that includes the Sawatch Range and continues south nearly to the valley of Saguache Creek (fig. 1). Such tilting may also provide a basis for understanding the asymmetrical distribution of preserved Thorn Ranch Tuff with respect to its caldera source. Non-preservation of Thorn Ranch Tuff west of Marshall caldera suggests that prior to tilting the paleo-terrain to the west was higher than to the east, thereby impeding ignimbrite deposition in that direction, or that higher western terrain promoted rapid erosion of the ignimbrite, soon after deposition.

All three large early Oligocene ignimbrites erupted from Sawatch Range calderas (Wall Mountain, Grizzly Peak, Badger Creek Tuffs) also have limited exposures west of their source calderas, in comparison to large preserved areas to the east (McIntosh and Chapin, 2004). This present-day asymmetry favors an interpretation of rapid erosion along higher slopes of Laramide-age Rocky Mountain uplifts, soon after ignimbrite eruption from sources in the Sawatch Range. In contrast, ignimbrites erupted from farther west and south in the San Juan region, where the volcanic rocks were deposited mainly on lessdeformed Mesozoic strata of the northeastern Colorado Plateau tend to be preserved widely in all directions around their caldera sources (Steven and Lipman, 1976; Lipman, 2000).

\section{Bonanza Caldera Cycle ( $33 \mathrm{Ma})$}

Bonanza caldera, source of the 33.1-Ma Bonanza Tuff, is the southernmost and youngest of the ignimbrite caldera centers (Grizzly Peak, Princeton, Aetna, Marshall, Bonanza), aligned along the Sawatch Range that marks the west shoulder of the 
Rio Grande rift in central Colorado (fig. 1). In contrast to the multicyclic nested caldera loci for successive eruptions at many large-volume ignimbrite flare-ups elsewhere, Bonanza is an isolated collapse structure that formed in response to a single ignimbrite eruption (photo 8). Although the western topographic rim of Bonanza impinges on Marshall caldera (photo 7.1A), projected structural boundaries of the two calderas appear to be largely or entirely separate.

Existence of a caldera in the Bonanza region was first inferred from gravity data (Karig, 1965), followed by recognition that the Bonanza latite of Patton (1916) and Burbank (1932) was welded tuff likely erupted from the Bonanza region (Bruns and others, 1971). As an outgrowth of exploration for porphyry deposits at depth below the vein mineralization at Bonanza, Varga and Smith (1984) synthesized available regional data, augmented by new chemical and isotopic data, as evidence for a trapdoor caldera of relatively modest size $(\sim 8$ $\mathrm{x} 12 \mathrm{~km}$ ), in which the subsided block was tilted westward and hinged on its east side. Details of this interpretation were problematic, however, because lavas that overlie the intracaldera ignimbrite are tilted steeply westward along with the underlying ignimbrite. Such a relation would require the caldera to have subsided after emplacement of the lavas, rather than accompanying the ignimbrite eruption.

Alternatively, Bonanza caldera is here interpreted as a much larger resurgent caldera, $20 \times 25 \mathrm{~km}$, in which the caldera floor was uplifted and steeply tilted after subsidence (figs. 5, 10). The previously inferred eastern hinge zone is instead inferred to be the crest of a large elliptical resurgent uplift (Whale Hill dome) within a caldera block that occupies much of the Bonanza map area (photo 8.1). Small remnants of east-dipping Bonanza Tuff are preserved on deeply eroded east flanks of the Whale Hill dome, but the east margin of the caldera is concealed beneath the San Luis Valley segment of the Rio Grande rift (fig. 10) with the possible exception of a small segment of the northeast caldera wall at Round Mountain (photo 8.4). In contrast, remnants of the original topographic caldera rim, though erosionally modified, are well preserved as high ridges (photos 8.2, 8.3) on southwest to northwest sides. As a result of the larger caldera size and revised correlation of the outflow ignimbrite, the combined intracaldera and outflow volume of Bonanza Tuff is estimated at about $1,000 \mathrm{~km}^{3}$ (Lipman and others, 2015), in contrast to the prior estimate of less than $50 \mathrm{~km}^{3}$ by Varga and Smith (1984).

\section{Pre-Bonanza Caldera Volcanism}

The composite volcanic highland where the caldera formed is dominated by intermediate-composition to silicic lavas from several eruptive centers. Dacite and rhyolite lavas high in the precaldera assemblage are more abundant at Bonanza than at other ignimbrite centers in the San Juan region and appear to record a prolonged history of magma assembly and evolution toward evolved compositions (33.7-33.2 Ma). Interlayered volcaniclastic rocks are less abundant than elsewhere in the San Juan Mountains, consistent with the inference of proximal deposition to construct a pre-caldera highland.
Presence of a central highland, prior to eruption of the Bonanza Tuff, is also supported by deposition of this ignimbrite in broad radial paleovalleys that are especially well preserved on the west and south flanks of the caldera (Varga and Smith, 1984). Effects of any caldera-related tumescence and possible broad resurgence are difficult to evaluate but would have been subordinate to eruptive processes in generating the overall present-day geometry of the precaldera volcanic sequence. Much of the highland constitutes fill of the earlier Marshall caldera, and most dated lavas are closer in age (33.9-33.6 Ma) to that caldera than to Bonanza. Only on Sargents Mesa and along the south flank of Bonanza caldera, near Saguache Peak, do relatively low-precision whole-rock dates on andesitic lavas (33.45-33.25 Ma) approach the age of the Bonanza cycle.

\section{Bonanza Tuff}

In contrast to the one-sided distribution of preserved Thorn Ranch Tuff in relation to its source from Marshall caldera, Bonanza Tuff is preserved widely both to the east and west of its source caldera (fig. 12, sheet 2). Any deposition of this ignimbrite in the vicinity of the Sawatch Range to the north has been completely eroded, however, and it has been covered by younger volcanic deposits or eroded south and west of the Saguache paleovalley.

The Bonanza Tuff is characterized by exceptionally large and complex lateral and vertical variations in chemical and phenocryst compositions (photo 9.1), from dark crystal-rich silicic andesite and dacite (unit Tbd: $25-35 \%$ plagioclase, biotite, augite; $60-66 \% \mathrm{SiO}_{2}$ ) to light-colored crystal-poor rhyolite (unit Tbr) that consists mainly of fine ash ( $\sim 5 \%$ sanidine, plagioclase, biotite; $73-76 \% \mathrm{SiO}_{2}$ ). A distinctive feature of the dacitic tuff, in both intracaldera and outflow deposits, is the presence of several percent of small angular lithics (typically several centimeters or less), dominantly fragments of andesitic lava. Flattened pumice fiamme are conspicuous in the dacite, commonly $5 \mathrm{~cm}$ or more long (fig. 13B, $C$, sheet 2). In contrast, lithic fragments are rare in the outflow rhyolite, and fiamme are small and obscure. Uniquely among rocks of the SRMVF, even mafic dacite $\left(62-64 \% \mathrm{SiO}_{2}\right)$ has phenocrysts of sanidine, while some rhyolite contains trace hornblende and titanite.

Prior studies had distinguished a lower dacite (latite) and upper rhyolite, starting with the mining district study by Burbank (1932), but the eruptive significance of the compositional change had remained uncertain. From work on the southwest flank of the Bonanza center, Bruns and others (1971, p. 187) concluded that the "Bonanza Tuff consists of two cooling units." Varga and Smith (1984) later described the Bonanza Tuff as consisting of two sheets, each a simple cooling unit, not compositionally comagmatic, and erupted from geographically separate vents. Neither of these studies specifically discussed the presence or absence of evidence for a time break, such as bedded tuff or other sedimentary units, between the two Bonanza cooling units, but the implied interpretation was the existence of two separate ignimbrites, an interpretation continued by McIntosh and Chapin (2004). In contrast, this work shows that all compositional variations in both intracaldera and outflow Bonanza Tuff occur within a single complex ignimbrite sheet characterized by compound welding zonations. 
West and south of Bonanza caldera, the outflow ignimbrite sheet is dominantly dark brown crystal-rich dacite (photo 9.2), but some proximal sections contain densely welded lower crystal-poor rhyolite, a thick central zone of widespread dacite that grades abruptly upward into less welded rhyolite, and, locally, an upper welded dacite (fig. 12). The compositional transitions correspond imperfectly with welding breaks. For example, the change from main dacite to upper rhyolite is associated with a bench-forming zone of weaker welding between dual cliffs of densely welded tuff, where well exposed along lower Saguache Creek (for example, Lipman and others, 2013, Stop 1-7), but the upward gradational decrease in crystal content and increase in silica mainly occurs high in the lower cliff rather than coincident with the zone of least welding. Rare partings defined by abrupt changes in pumice or lithic size or abundance within the ignimbrite (fig. 13A) are interpreted as recording pulsation of eruption intensity or ignimbrite-emplacement dynamics during essentially continuous ignimbrite deposition. No evidence was observed for existence of significant time breaks during deposition, such as interlayered bedded-surge, tephra-fall, or fluviatile ash deposits in either the outflow ignimbrite or in the thick intracaldera accumulation.

In contrast, outflow Bonanza Tuff, which is preserved $80 \mathrm{~km}$ beyond the map area to the northeast (photo 9.3), was described until recently as a separate ignimbrite of crystalpoor rhyolite, the Gribbles Park Tuff (Epis and Chapin, 1974; McIntosh and Chapin, 2004). The eastern outflow sheet consists dominantly of light-colored crystal-poor rhyolite but contains a thin internal zone of red-brown dacite, at least in locations such as the well-exposed section at Two Creek (lat $38^{\circ} 36.6^{\prime}$ N., long $105^{\circ} 46.7^{\prime} \mathrm{W}$.) that has been used as a reference section (Epis and Chapin, 1974; McIntosh and Chapin, 2004; tables 3, 4 of this report). Thus, the eastern outflow has a similar general compositional zonation as the west, but with a much greater proportion of rhyolite to dacite. Based on preserved extent, total volume of the eastern outflow must be large, at least several hundred cubic kilometers. This unit is not simply correlative with the upper rhyolite zone in proximal western sections as proposed by McIntosh and Chapin (2004, p. 230), who recommended "that the name Bonanza Tuff be restricted to the lower crystal-rich dacitic unit, and that Gribbles Park Tuff be used for the upper rhyolitic unit." All the compositional zones in the outflow ignimbrite, both to west and east, are within a single variably welded ignimbrite sheet, displaying compound cooling (Smith, 1960) but without depositional breaks, for which the name Bonanza has precedence, going back to Patton (1916) and Burbank (1932). Accordingly, Gribbles Park Tuff is not used here as a stratigraphic name for any compositional subunit of the Bonanza Tuff.

The thick intracaldera Bonanza Tuff (photo 9.4) contains even more complex compositional variations (fig. 13). Where a complete ignimbrite section ( $2.5 \mathrm{~km}$ thick) from caldera-floor rocks to postcollapse lavas is exposed on the west flank of the resurgent dome (fig. 14A, sheet 2), rhyolite and dacite compositional zones alternate as many as 13 times, as identified in variably altered rocks by contrasts in crystal content and groundmass color. Dacite is volumetrically dominant, but the eruptive sequence began and ended with rhyolite. The incomplete caldera-fill section on the steeply dipping northeast flank also contains multiple rhyolite-dacite alternations and is at least 1.5-2 $\mathrm{km}$ thick, including thick interleaved landslide-breccia deposits. Other than contacts against landslide breccias, all compositional and welding variations are gradational. The multiple zones of dacitic tuff are typically densely welded (fig. $11 B, C$ ); many of the rhyolite zones appear to be less welded, although degree of welding is more difficult to evaluate because of common absence of large pumice/fiamme lenses and widespread intense alteration.

The initially erupted lower rhyolite (photo 9.5) is relatively thin and small in volume within the caldera, varying greatly in thickness within short distances laterally that probably reflect topography of the pre-eruption volcanic terrain. This zone is as much as $100 \mathrm{~m}$ thick locally on the southwest flank of the resurgent dome but is largely absent on the north flank. The dacitic tuff is typically densely welded (fig. 13); in places where propylitically altered, the intracaldera dacite is identifiable as welded tuff only by the typical presence of abundant small angular fragments of andesitic lava. Much of the rhyolite is only moderately welded, but some deep intracaldera zones are densely welded to fluidal, and locally rheomorphic. The lower rhyolite is especially fluidal and lava-like on the west caldera rim (fig. $11 D, E)$ and along the steeply dipping northeast flank of the resurgent dome. Pumice lenses, where distinguishable in fluidal and rheomorphic zones (both rhyolitic and dacitic), commonly define a prominent lineation with prolate elongation ratios of as much as 20:1. Lineations are especially well developed low in the thick ignimbrite section that is so well preserved on the west flank of the resurgent dome; there, they typically plunge nearly directly down dip.

The weighted-mean age for sanidine from intracaldera Bonanza Tuff $(33.05 \pm 0.06 \mathrm{Ma})$ is marginally younger than that for the outflow ignimbrite $(33.12 \pm 0.03 \mathrm{Ma})$. Although within analytical uncertainty, this difference might reflect prolonged cooling of the multi-kilometer-thick intracaldera accumulation or possible effects of later alteration.

\section{Caldera Subsidence}

The asymmetric areal distributions of rhyolite and dacite erupted from Bonanza caldera provide information on paleotopography and timing of caldera collapse. At inception of the eruption, a barrier on the west side, either prevolcanic structural highlands or earlier volcanic constructs, must have impeded ignimbrite flow in that direction; early erupted rhyolitic tuff spread mainly to the east.

The relatively modest thicknesses and limited areal extent of the lower rhyolite zone within the caldera indicate that caldera collapse began relatively late during this phase of the Bonanza ignimbrite eruption. If subsidence had accompanied inception of the eruption, or even triggered initial magma expulsion as inferred in some caldera models (for example, Sparks and others, 1985; Lindsay and others, 2001; Gudmundsson, 2008; Gregg and others, 2012; Cashman and Giordano, 2014), a much greater thickness and volume of the early rhyolite should have ponded within Bonanza caldera. If a volume of early rhyolite tuff comparable to that in the eastern outflow sheet (estimated at 200-300 $\mathrm{km}^{3}$ ) had accumulated concurrently within Bonanza caldera, the 
thickness of intracaldera early rhyolite would have been greater than $1 \mathrm{~km}$. Even though later stages of the Bonanza eruption were accompanied by concurrent caldera subsidence, the estimated outflow volume of lower rhyolite alone $\left(200-300 \mathrm{~km}^{3}\right)$ is comparable to that of several uniform crystal-rich dacites in the SRMVF (table 1) and elsewhere, suggesting that no simple correlations exist between eruptive volume or magma composition and inception of caldera subsidence.

Inception of caldera collapse late during eruption of the lower rhyolite appears to have disrupted the western barrier, permitting modest accumulation of lower rhyolite within the caldera and very locally in proximal outflow to the west (fig. 13). Increased eruptive drawdown and (or) tapping a new sector of a compositionally complex magma reservoir then led to inception of dacite eruptions that were able to spread widely to the west while accumulating thickly within the subsiding caldera depression. In response to continued subsidence during later phases of the ignimbrite eruption, the Bonanza Tuff ponded to a thickness of as much as $2.5 \mathrm{~km}$ within the caldera.

Interfingered with the alternating zones of rhyolite and dacite ignimbrite within Bonanza caldera are many irregular lenses of brecciated precaldera rocks (fig. 13), both mesobreccia (photo 10.1) and much larger masses of little-broken massive lava, which are interpreted as landslide debris derived from caldera walls that had become oversteepened during subsidence. Individual blocks in some lenses are larger than outcrops and are termed megabreccia (Lipman, 1976b). Some breccias are heterolithologic on outcrop scale, but in other large areas blocks are compositionally uniform lava. The most voluminous megabreccia is low in the thick caldera fill, close to or in direct contact with caldera-floor rocks; boundaries between megabreccia and floor can be obscure. The deep megabreccia is best developed along the southwest and north margins of the central resurgent uplift, in proximity to caldera ring faults and the inner structural wall. Exposures are especially good on the dry southwest-facing slopes of Kerber Creek valley between Express and Schoolhouse Gulches (GG; photo 10.3). Much less megabreccia appears to have reached more central areas of the caldera fill, as exposed high along west flanks of the resurgent dome from Hayden Peak to Whale Hill and Round Mountain (WH), presumably because the landslides tended to deposit as talus-like cones in proximity to the inner caldera walls. The voluminous deep megabreccias (photo 10.2), in places deposited directly on caldera-floor rocks, are interpreted to record a catastrophic initial phase of caldera collapse late during eruption of the lower rhyolite zone. Thus, intracaldera landslide breccia at the base of an intracaldera ignimbrite sequence need not necessarily document caldera collapse (or vent enlargement) concurrently with eruption inception.

Smaller lenses of mesobreccia and megabreccia interfinger at higher horizons of the intracaldera Bonanza Tuff, indicating that caldera walls became oversteepened intermittently during subsidence but never again as severely as during the initial collapse. Most of the breccia consists of andesite and dacite of the Rawley complex, but landslide debris with Proterozoic clasts is also present, especially within northern sectors of the caldera fill. A Proterozoic source for landslides along this sector would have required deep early subsidence $(>1 \mathrm{~km})$, cutting down below the volcanic fill of Marshall caldera. A puzzling area of brecciated Proterozoic granodiorite at the junction of Kerber and Little Kerber Creeks is also interpreted as resulting from caldera-collapse events, mainly caldera-wall landslides but perhaps also involving brecciation adjacent to the main ring fault, as discussed more fully in a later section. Another major subsidence event late during the eruption is recorded by the approximately 1,000-m difference in elevation between high remnants of Bonanza Tuff, plastered against the western caldera wall between Antora Peak and Windy Point (fig. 5), versus the uppermost intracaldera tuff within the caldera structural block that subsided along the Kerber Creek ring fault (fig. 14A).

Varied thickness and lateral extent among the multiple interfingering zones of rhyolite and dacite in the intracaldera ignimbrite probably reflect multiple factors, including surface irregularities on the pre-eruption lava assemblage, depositional slopes generated by caldera-wall landslide deposits, and modestly asymmetric caldera subsidence. Caldera-floor morphology probably mainly affected distribution and thickness of the lower rhyolite. The differing thickness and extent of many compositional zones higher in the intracaldera accumulation are spatially unrelated to breccia lenses. These variations suggest that the ignimbrite depositional surface became weakly tilted in diverse directions during the course of caldera subsidence, and tuff accumulated more thickly downslope. Tilting and asymmetrical collapse is well documented at ignimbrite calderas elsewhere and in analogue models, especially early downsagging and trap-door subsidence in small-volume eruptions (Cole and others, 2005; Acocella, 2007). Weakly asymmetrical subsidence at Bonanza is also suggested by rheomorphic structures in rhyolitic tuff deep in the caldera fill and by strongly lineate compaction and elongation of large pumice lenses in dacitic tuff (fig. 13A). Such flowage structures seem likely in calcalkaline ignimbrites mainly when deposited against a slope (for example, Chapin and Lowell, 1979; John and others, 2008), especially in a dynamic environment of increasing steepness that could occur during caldera collapse.

Despite this evidence for modest asymmetry at times during subsidence at Bonanza, the overall geometry is coherent subsidence of a structural block about 15 x $20 \mathrm{~km}$ across, accommodated along peripheral ring faults. Dips of foliation defined by pumice fiamme (most $35-55^{\circ}$ ) do not vary significantly or systematically upward through the $2.5-\mathrm{km}$ section of the intracaldera ignimbrite section exposed on the west flank of the resurgent dome (fig. 10), indicating that the overall subsidence did not involve sustained progressive tilting. No major fault offsets have been recognized within caldera-floor lavas of the main subsided block; subsidence was dominantly pistonstyle, not piecemeal.

\section{Caldera-Collapse Faults}

Caldera collapse during eruption of the Bonanza Tuff was primarily accommodated along ring faults that are largely concealed beneath surficial deposits along the valley of Kerber Creek and its tributaries (photo 8.3A). Satellitic fault strands as much as several kilometers outside of the major ring-fault 
system accommodated additional subsidence, slumping of large blocks along the south and west caldera margins, and modest back rotation. As much as about $4 \mathrm{~km}$ of stratigraphic offset occurs along the concealed ring faults on the west side of the caldera, as constrained by a cross section from Whale Hill to Flagstaff Mountain (fig. 14A). Net offset along the Kerber Creek (fig. 10) fault diminishes farther to the south, approaching zero at the junction with Little Kerber Creek and the intersection with the anticlinal crest of the Whale Creek dome (figs. 5, 10); the decreased displacement along this southern fault segment is interpreted to result from reversed displacement and uplift during resurgence. To the north, caldera faults are largely concealed beneath collapse-related megabreccia and later lavas of the Bonanza eruptive cycle; it remains unclear whether subsidence was as deep as to the south and west. The few other SRMVF calderas that are sufficiently deeply eroded to expose bounding ring faults display varied structural patterns. The multiple interconnected fault strands associated with the single ignimbrite eruption at Bonanza caldera (fig. 10) differ from the predominantly single ring-fault strand that is well exposed at Lake City, or from the nested faults at Grizzly Peak and probably at Mount Aetna (Lipman, 1976a; Fridrich and others, 1998; Shannon, 1988).

Andesitic and dacitic lavas of the caldera floor that are adjacent to ring faults along Kerber Creek and to the south are locally severely shattered, involving textures and structures that seemingly have not been widely recognized at calderas elsewhere. Angular blocks mostly less than $0.5 \mathrm{~m}$ across are juxtaposed, with only a minor matrix of comminuted lava (photo 11). In many exposures, finely shattered fragments fit together without large-scale rotation or other movement (photos $11.1 B, 11.2 C$ ), and such rocks grade into more massive lavas of the caldera floor within 100-200 m away from mapped ring faults. In some zones, breccias with angular and rounded clasts are matrix supported (photo $11.1 C$ ), but despite areal proximity to megabreccia at the base of the intracaldera Bonanza Tuff, no tuffaceous component is present in the shatter breccia. Although fault planes, slickensides, or other evidence of offset are sparse, the close proximity of the shatter breccias to the main calderacollapse faults and thin steeply dipping zones of more finely pulverized lava (photo 11.2B) suggest that the shatter breccia formed during subsidence (or resurgence), perhaps due in part to hydraulic fracturing. Temperatures must have remained low during fracturing, however, as evidence is absent for silicification or other mineral precipitation from high-temperature hydrothermal fluids such as described along some faults elsewhere (Caine and others, 2010, and references therein). Compositions of breccia matrix differ little from bulk andesite compositions, other than modestly variable alkali ratios and higher loss on ignition (LOI) values (table 4). Alternatively, and perhaps more likely, shattering of the floor rocks may have resulted from compression and crushing of the subsiding structural caldera block in proximity to steeply inward dipping ring faults.

Also interpreted as related to caldera subsidence are several east-trending arcuate faults south of Kerber Creek, which juxtapose Paleozoic sedimentary formations against Proterozoic rocks (fig. 10). These were described by Burbank (1932, p. 39-40, plate 3) as low-angle thrust faults of prevolcanic age, but no specific evidence was cited for a thrust interpretation, other than the presence of Proterozoic granodiorite on high ridges south of the southward-dipping Paleozoic strata exposed low along Kerber Creek. Detailed tracing of faults across ridges and gullies, with better base-map and GPS control than was possible for Burbank, documents generally steep dips, at least $45-60^{\circ}$, although vertical relief is insufficient to quantify more precisely. Accordingly, rather than low-angle thrusts active during Laramide compression, these faults are here interpreted as large-scale middleTertiary block slumps, related to peripheral subsidence and failure along oversteepened walls along the south margin of Bonanza caldera (fig. 14B). Back-rotation during slumping would have produced southward dips of the Paleozoic strata that crop out at low elevations. Additionally, at least some component of the southward dips in the prevolcanic rocks likely resulted from tilting along the lower south flank of the large resurgent dome within the caldera.

\section{Caldera-Floor Structures}

Particularly revealing within Bonanza caldera are the areally widespread exposures of structurally coherent caldera-floor lavas and basal deposits associated with the ignimbrite eruption and caldera collapse (photo 8.1). Other than the thick section of Bonanza Tuff on the lower west flank, virtually the entire resurgently domed caldera floor has been erosionally exhumed at stratigraphic levels close to original contacts with the basal intracaldera ignimbrite, over an area about $10 \mathrm{x} 15 \mathrm{~km}$ across constituting much of the ring-fault-bounded caldera structural block (fig. 10).

At Bonanza caldera, stratigraphic levels close to the original caldera floor are exposed for about two-thirds of the area of the ring-fault-bounded structural core (the little-broken thick sequence of overlying intracaldera ignimbrite covers about $15 \%$ of the west flank of the resurgent dome, while on the east side surficial deposits of the San Luis Valley conceal an additional 15-20\%). Exposures of the stratigraphic transition from calderafloor lavas to ignimbrite fill at Bonanza are especially good on the relatively dry and weakly vegetated south-facing slopes above Kerber Creek. In this area, fractured but seemingly coherent thick sequences of andesite and dacite lavas merge imperceptibly upward into shattered outcrops of similar lava, between which irregular crack fills and pockets of dacitic and rhyolitic tuff are interpreted as matrix between megabreccia blocks (photo 10.2). Within the near-floor megabreccia, most good outcrops consist of erosion-resistant intermediate-composition lavas. Much of the matrix tuff is weakly welded, lithic rich, and exposed only as fragments on slopes. As a result, contacts between caldera floor versus caldera-fill megabreccia can be broadly gradational and locatable only approximately in many places.

Such deep levels of caldera structure have rarely been observed on such a comparable areal scale elsewhere, where floor rocks are seen mainly in oblique cross sections through structurally disrupted and tilted caldera remnants, as in the Great Basin of the western United States (for example, Henry and John, 2013; Best and others, 2013). Caldera-floor levels of greater areal extent are well exposed at several well-documented large Paleozoic ignimbrite calderas, for example, Ordovician Scafell and Glen 
Coe calderas in Great Britain (Branney and Kokelaar, 1994; Moore and Kokelaar, 1998) and Permian Sesia and Ora calderas in northern Italy (Quick and others, 2009; Sbisà, 2010; Willcock and others, 2013), but these differ from Bonanza in important aspects, including morphologic preservation, eruptive history, and tectonic setting (Lipman and others, 2015).

\section{Ignimbrite Fracture Fills}

Within the near-floor megabreccia, much of the matrix tuff is weakly welded, lithic rich, and exposed only as fragments on slopes, but cracks in some outcrops contain tuffaceous fills that are strongly welded and have steeply dipping fiamme (photo 12). The rhyolitic crack fills (unit Tbfr) are relatively thin (typically $<1-2 \mathrm{~m}$ ), discontinuous (commonly traceable for a few tens of meters or less), and irregular in shape and trend. In places, obviously welded tuff grades along strike into flowlaminated rhyolite that lacks obvious fragmental textures; a few parallel dike-like bodies appear to consist entirely of rhyolite without lithic fragments or other surviving pyroclastic textures. Some of these could be intrusive dikes of fluidal rhyolite or vent fissures for ignimbrite eruptions, but available evidence suggests that they are better interpreted as surficial fills between blocks of early caldera-collapse megabreccia, injected down into cracks that opened dilatantly during caldera subsidence.

Well-exposed fracture fills of highly welded and rheomorphic rhyolitic tuff, on the slopes north of Kerber Creek between Express and Schoolhouse Gulches (GG), tend to be parallel to adjacent caldera ring faults (photo 12.1), but all identified fracture fills of highly welded and rheomorphic rhyolitic tuff are located near the transition from caldera floor upward into caldera-fill megabreccia and matrix tuff. No comparable fracture-fill tuff has been found at deeper exposed levels of caldera-floor lavas or in underlying Paleozoic and Proterozoic rocks. Most fracture fills with identified pyroclastic textures consist of crystal-poor rhyolite (only one fracture fill of dacite tuff is well exposed), similar to that of the early erupted lower rhyolite phase of the ignimbrite sheet, as would be anticipated if caldera subsidence began during this phase of the eruption. Similar local pods of eutaxitic to fluidal rhyolite are present elsewhere on flanks of the resurgent dome, especially within large northern areas interpreted as megabreccia on both sides of Clover Creek (WH), but these areas are heavily vegetated and exposures are limited.

The highly welded to fluidal rhyolite in some dike-like fracture fills (photo 12.2) in places merges with areas of less-welded tuffaceous matrix in the megabreccia and with larger pockets and lenses of more uniformly welded intracaldera Bonanza Tuff that dip conformably with the flanks of the resurgent dome. Notably, high along the ridge west of Schoolhouse Gulch (GG), scattered steep lenses of rhyolitic Bonanza Tuff are spatially associated with a sheet-like erosional remnant of flow-layered rhyolite (fig. 15, sheet 2) interpreted as rheomorphic lower Bonanza Tuff (unit Tbrr) despite its fluidal lava-like fabric (photo 10.3). Where contacts with adjacent caldera-floor andesite are well exposed, especially at the south end of the main body, masses of andesite ranging in size from several meters across down to centimeter-size chips are enclosed by fluidal rhyolite that is locally flow folded.
In striking contrast to the weakly welded matrix tuff associated with most caldera-collapse breccias at Bonanza caldera (photo 10.1) and elsewhere (Lipman, 1976b), the texture of the rhyolite along Schoolhouse Gulch is strikingly lamellar adjacent to andesite clasts (photo 10.3C), even in thin-section scale; only in strain shadows adjacent to phenocrysts and to lithic fragments are local areas of shard texture preserved. The extreme welded and rheomorphic flowage of rhyolitic Bonanza Tuff along this basal contact with caldera-floor lavas is tentatively interpreted as related to thermally efficient emplacement followed by rapid deep burial beneath the thick intracaldera ignimbrite accumulation that is projected to have overlain it. Alternative interpretation of this unusual body as a large irregular ignimbrite vent fill seems less likely, because of the overall sheet-like geometry of the rhyolite.

In a different setting, a lens of partly welded rhyolitic tuff in a couloir that trends northeast from the summit of Flagstaff Mountain (BZ, lat $38^{\circ} 16.61^{\prime}$ N., long $106^{\circ} 11.83^{\prime} \mathrm{W}$.) appears to truncate andesitic lavas that dip westward along the inner caldera wall, at elevation about $11,400 \mathrm{ft}(3,475 \mathrm{~m})$. As exposed in rugged cliffs, the tuff lens strikes about N. $20^{\circ} \mathrm{W}$., with variable dips from $\sim 50^{\circ} \mathrm{W}$. to near vertical, is $5-15 \mathrm{~m}$ thick, and can be traced in outcrop and float for about $150 \mathrm{~m}$ along strike (photo 5.2). The tuff (table $5 ; 75.80 \% \mathrm{SiO}_{2}$ ) is similar in composition to crystal-poor rhyolitic Bonanza Tuff, and finely laminated ash in a zone $\sim 0.5$ $\mathrm{m}$ thick at the upper contact of the tuff lens suggests origin by winnowing during filling of a crack along the inner caldera wall. Alternatively, the tuff unit may have formed as a small ignimbrite deposited within the dominant lava sequence of the Rawley complex. The steep dips could have resulted from rotation of a large slab that slumped downward along the caldera wall.

Some ignimbrite crack fills at Bonanza could be interpreted as intrusive dikes of fluidal rhyolite or vent fissures for ignimbrite eruptions, but their stratigraphic distribution, lateral textural variations, and compositions suggest that they are best interpreted as surficial fills between blocks of early caldera-collapse megabreccia, injected down into cracks that opened dilatantly during caldera subsidence. Dike-like pyroclastic bodies at several ignimbrite and caldera settings elsewhere have been similarly interpreted as dilatant crack fills (Lipman, 1964; Branney and Kokelaar, 1994, p. 525; Best and others, 2013, p. 920).

\section{Ignimbrite and Subsidence Volumes}

As elsewhere in the SRMVF, estimates of magmatic volume erupted as ignimbrite are highly approximate at Bonanza because of extensive subsequent erosion and other uncertainties. Total eruptive volume of the Bonanza Tuff is estimated at about $1,000 \mathrm{~km}^{3}$ (table 1), based on intracaldera and outflow distribution and thickness. The volume of intracaldera ignimbrite is estimated to be greater than $500 \mathrm{~km}^{3}$, based on an area of 250 $\mathrm{km}^{2}$ of the subsided structural block $\sim 15 \times 20 \mathrm{~km}$ across within the arcuate ring fault and an average tuff thickness of $2 \mathrm{~km}$ or greater. While much of the intracaldera tuff has been eroded, its thickness is as much as $2.5 \mathrm{~km}$ in the complete section on the west flank of the resurgent dome and more than $1.5 \mathrm{~km}$ in the steeply dipping incomplete section on the northeast side (fig. $14 A$ ). Additional ignimbrite fill accumulated in the collar area 
between the inner topographic wall and the ring fault (photo $9.4 A$ ), but its volume would have been partly counterbalanced by the caldera-wall landslide deposits within the structural block. The preserved extent of outflow Bonanza Tuff, at least 40 $\mathrm{km}$ west from the caldera rim (Lipman, 2012) and $70 \mathrm{~km}$ to the east (fig. 12; McIntosh and Chapin, 2004) and typical thickness of several tens to as much as a hundred meters yield an estimated volume of several hundred cubic kilometers for each sector. Thus, even though deposition along paleovalleys, erosional removal of original deposits to the north, and cover by younger volcanic rocks to the southwest in the San Juan region preclude more detailed estimates for the Bonanza Tuff, intracaldera and outflow volumes seem roughly subequal, a crude approximation that appears to hold for many large ignimbrites (Lipman, 1984; Mason and others, 2004; Folkes and others, 2011).

In comparison, the volume of total structural subsidence at Bonanza caldera is also estimated at about $1,000 \mathrm{~km}^{3}$, based on average vertical subsidence of at least $3 \mathrm{~km}$ for the relatively coherent equant block within the ring fault $(>2 \mathrm{~km}$ of intracaldera ignimbrite, overlain by $>1 \mathrm{~km}$ of caldera-filling lava). Comparable multi-kilometer subsidence is also documented by minimum thicknesses of caldera-filling ignimbrite and postsubsidence lavas at other large middle Tertiary calderas such as Lake City and Grizzly Peak in the SRMVF (Lipman, 1976a, 2007; Fridrich and others, 1998) and elsewhere in the U.S. Cordillera (Henry and John, 2013; Best and others, 2013), but the widely exposed caldera floor and complete section of ignimbrite fill exposed at Bonanza seem unique.

\section{Postcollapse Lavas and Intrusions}

After the ignimbrite eruption and concurrent caldera subsidence, compositionally diverse lavas ranging from andesite to highsilica rhyolite filled the caldera to overflowing and spread across adjacent slopes, as preserved in erosional remnants to the northwest and southwest (photos 13.1, 13.2). Ages of the upper lava sequence of the Bonanza center, including caldera-filling flows, are bracketed as 33.15-32.25 Ma by the underlying Bonanza Tuff and overlying Saguache Creek Tuff, but the approximately 1-kmthick intracaldera sequence capped by sanidine-bearing dacite (unit Tbdk) and Porphyry Peak Rhyolite (unit Tbfr, photo 13.3) was emplaced rapidly by $33.04 \mathrm{Ma}$ (mean of five samples; table 6). The lowermost intracaldera lavas (Squirrel Gulch Andesite, Tbas) directly overlie upper-rhyolitic ignimbrite of the Bonanza Tuff and were tilted steeply along with the underlying tuff during later resurgent uplift. In contrast, some late caldera-filling lavas (Porphyry Peak Rhyolite, sanidine-bearing dacites) may be tilted less, as based on contact geometry (primary depositional attitudes are difficult to constrain precisely in these massive viscous lavas that commonly form widespread talus on steep vegetated slopes). The tilted intracaldera lavas at Bonanza, erupted prior to and during resurgence, thus are analogous to voluminous early postcaldera rhyolites at Long Valley $\left(\sim 100 \mathrm{~km}^{3}\right.$, as much as 600 $\mathrm{m}$ thick), also erupted during resurgence within $\sim 100 \mathrm{k} . \mathrm{y}$. after caldera collapse (Bailey and others, 1976). Postcollapse lavas are not exposed on the deeply eroded east side of the caldera, but a distinctive thick lava sequence (unit Tbdh) of crystal-poor silicic dacite (69-70\% $\mathrm{SiO}_{2}$ ) on Hayden Peak (WH) appears to have accumulated relatively late $(\sim 32.8 \mathrm{Ma})$ in a paleovalley carved deeply through intracaldera Bonanza Tuff high along the crest of the resurgent dome (photo 13.4).

In contrast to many other large ignimbrite calderas, only small deposits of lake sediments (unit Tbs) or late pyroclastic rocks (unit Tbav) are preserved in the postcollapse lava fill at Bonanza. The rarity of intracaldera volcaniclastic rocks at Bonanza is consistent with rapid accumulation of the lavas, bracketed within about 100 k.y. after the Bonanza eruption and prior to major resurgent uplift. The time span between the Bonanza ignimbrite eruption at $33.12 \pm 0.03 \mathrm{Ma}$ and that of Porphyry Peak Rhyolite that overflowed the north caldera margin by $33.03 \pm 0.04$ Ma indicates that at least $1 \mathrm{~km}$ of lava accumulated in the northwestern caldera area within about 90 k.y. (as little as 20 k.y. and no more than 160 k.y., based on the 2-sigma uncertainties for the weighted-mean ages).

Compositionally and texturally diverse intrusions varying from gabbro to silicic granitic rocks intruded the caldera floor and lowest ignimbrite fill, forming widely scattered surface exposures that are inferred to represent an irregular roof zone of a more continuous composite body at slightly greater depth (photo 14). The largest intrusions crop out on the deeply eroded eastern side of the Whale Hill resurgent dome (photo 14.1). Texturally diverse outcrops of granodiorite-andesite, which form the $3 \times 7$ $\mathrm{km}$ exposed area of the Turquoise Mine intrusion (photo 14.2) on the east side of the dome (WH), are compositionally similar to postcollapse andesite and dacite preserved on the western flank (BZ). Fine-grained intrusive phases (photo 14.2C) of the Turquoise Mine intrusion (unit Tta), covering areas as much as several hundred meters across, form bold outcrops of dense dark andesite $\left(55-56 \% \mathrm{SiO}_{2}\right)$ characterized by rectilinear jointing unlike the hackly fractures that characterize most andesite lavas in the Bonanza region. Some larger areas of the finer-grained phases are composite, containing internal contacts between subunits differing in phenocryst abundance, size, or mode. The areal abundance of intrusive andesite, comingled with coarser granodiorite (unit Ttg), is interpreted as representing the roof zone of a large intermediate-composition intrusion that would be less heterogeneous at greater depth. Several small exposures of similar granodiorite to andesite crop out farther west, along tributaries of Kerber Creek, and mineral-exploration drilling on Whale Hill (figs. 5, 10) penetrated granitoid rocks at depths of about $1 \mathrm{~km}$ (Cook, 1960; Gordon Gumble, written commun., 2006).

A pluton of aplitic to porphyritic granite (units Tas, Tgs; photo $14.3 A$ ) exposed at near-roof levels in an $\sim 3 \times 4 \mathrm{~km}$ area of upper Spring Creek (WH) is compositionally similar to postcaldera lavas of the Porphyry Peak Rhyolite. The roof zone and margins of the Spring Creek intrusion are aplitic porphyry (74-77\% $\mathrm{SiO}_{2}$ ), containing 5-15\% euhedra of $\mathrm{K}$-feldspar; the deeper interior portions of the exposed intrusion are also porphyritic but have a medium-grained matrix that is modestly less silicic (72-73\% $\mathrm{SiO}_{2}$ ). Microperthitic and weakly argillized $\mathrm{K}$-feldspar from the granitoid intrusions has not been datable with precision comparable to volcanic sanidine, but the somewhat varied cooling ages (33.3-32.8 Ma; tables 5, 6) overlap those from the Bonanza Tuff and postcaldera lavas. These cooling ages, together with field relations, indicate emplacement 
of the resurgent plutons shortly after caldera eruption. Numerous other caldera systems display similarly rapid timing (for example, review by Lipman and Bachmann, 2015).

A roughly concordant tabular body of uniform dacite (67.4\% $\mathrm{SiO}_{2}$ ), the Eagle Gulch Dacite (unit Teg: latite of Burbank, 1932), was intruded between caldera-floor andesitic lavas and basal intracaldera Bonanza Tuff along a northeast-trending belt about $8 \mathrm{~km}$ long from the south side of Elkhorn Gulch (photo 14.3B) to the north slope of Elkhorn Peak (WH, BZ). The sill-like shape and uniform texture and composition of the Eagle Gulch Dacite differ from the more diverse granitoid intrusions, which are interpreted as uppermost levels of a vertically extensive composite intrusion coring the Whale Hill resurgent dome.

\section{Resurgent Uplift}

After the ignimbrite eruption and emplacement of calderafilling lavas, the caldera floor was arched into an exceptionally large and steep-sided resurgent dome (photo 15.1) that is gently arcuate to the east (figs. 5, 10, 14-16, sheet 1). Erosion has stripped most intracaldera Bonanza Tuff from the floor lavas along the crest of the resurgent uplift, which is well defined at present by gentle upland surfaces on Mount Manitou and Whale Hill (fig. 16; photo 15.2). Small remnants of Bonanza Tuff preserved along the crest of the resurgent structure at Round Mountain (photo 15.2A) and Elkhorn Peak provide critical constraints on caldera-floor geometry and structure along highest parts of the resurgent dome. Notably, caldera-floor lavas are at elevations above $3,700 \mathrm{~m}$ on the crest of the resurgent uplift, as high as comparable units on the west topographic rim (fig. 14A). This relation indicates $\sim 3.5 \mathrm{~km}$ resurgent uplift, equal to the subsidence documented by the thick caldera-fill section of ignimbrite and pre-resurgent lavas on the west flank of the dome. If thickness of the caldera fill centrally within the caldera had been similar to the west-flank section, the original dome crest would have had an elevation of $\sim 7,000 \mathrm{~m}$ above present-day sea level.

Dips on flanks of the Whale Hill resurgent dome are exceptionally steep and variable compared to resurgent uplifts at other well-documented ignimbrite calderas: $40-60^{\circ}$ on the west flank of the dome near Bonanza (BZ), where widespread preservation of intracaldera tuff provides robust structural control (fig. $14 A$ ); approaching vertical on the northeast flank (photo 15.3) in the Alder Creek area (WH) and also, locally, on the southwest flank of the south-plunging Sand Gulch anticline (photo 15.4) along Soda Spring Gulch (GG); but typically only $20-30^{\circ}$ on the southeast flank. This asymmetry may have resulted in part from broad younger tilting of the Bonanza region, within a zone of structural transfer between segments of the Rio Grande rift. Uplift appears to have been largely bounded and partly accommodated by the same ring faults that accomodated caldera subsidence. Resurgence is inferred to have been caused by multiple intrusions centrally within the caldera, including the granodiorite to granite bodies that are exposed on eastern and southern flanks of the dome.

The south margin of the resurgent dome is especially well constrained by the southeast-plunging Proterozoic-cored anticline and flanking Paleozoic sedimentary strata (figs. 10, $14 B$ ) that are stratigraphically much more precisely defined than the precaldera lava succession. The southern anticline has been previously interpreted as a prevolcanic (Laramide) structure (Burbank, 1932; Tweto and others, 1976; Cappa and Wallace, 2007). Dips of immediately overlying volcanic strata including Bonanza Tuff, although less widely measurable, locally are nearly as steep on the fold flanks and have a similar asymmetry as the well-stratified Paleozoic sedimentary strata, requiring that much of the tilting was postcaldera (fig. 10; photo 15.3). At least the main development of the fold accordingly must be Tertiary; it is here interpreted as the southern continuation of the elongate Whale Hill dome. Because the Proterozoic rocks in the core of the anticline are directly overlain by Tertiary lavas, without intervening Paleozoic sedimentary strata, this area must have also been a prevolcanic high. Perhaps a more open fold in the prevolcanic rocks influenced the location of postcaldera resurgence; alternatively, this area was simply a paleo-highland along a northwestern erosional truncation of Paleozoic strata.

Some faulting of the resurgent dome likely accompanied uplift, as is the case for other well-studied resurgent caldera structures that are characterized by keystone grabens and other uplift-related faults (for example, Valles, Creede, Timber Mountain, Lake City, Cerro Galan: Smith and Bailey, 1968; Steven and Ratté, 1973; Byers and others, 1976; Lipman, 1976a; Folkes and others, 2011). Aspects of the resurgent caldera structure at Bonanza were anticipated by Burbank (1932, p. 42-43), who concluded that "arching and tilting of the formations $* * *$ is believed to have been initiated by the intrusion of a large body of molten lava $* * *$. The crust consequently bulged upward, blocks of it were tilted in different directions." Prior mapping depicted an intricate mosaic of rectilinear faults in the mining district (Burbank, 1932, plate 1), but many of the depicted faults were required to accommodate an overly simplified stratigraphic sequence, without adequate available concepts of ignimbrite-eruption and caldera-filling processes.

In this study, only a few faults with sizable documentable displacements have been mapped within the resurgent dome. Reliable identification of fault displacements has been elusive on heavily vegetated slopes where talus is widespread, outcrops rare, reliable stratigraphic marker horizons sparse, and underground mines no longer accessible. More faults than have been mapped are likely within the resurgent block, but major fault repetitions are unlikely. In contrast to the mapping by Burbank, Patton (1916, p. 63), with access to many more of the underground mine workings in the Bonanza district, noted that "While minor faults involving a movement of a few inches or, at most, a few feet are of common occurrence, no evidence of faulting on a large scale has been discovered." The most important fault in mine workings is stated to be the Paragon fault (not visible at map scale) that trends east along Rawley Gulch, although other faults tend to have north-northwest trends (Patton, 1916, p. 64, plate 19; Burbank, 1932, plate 8). Beyond the mining district, relatively coherent subsidence and subsequent resurgence of the caldera floor are well documented in the southern caldera area, where detailed structural control is provided by stratigraphy of the regional lower Paleozoic formations. These strata dip steeply on flanks of the resurgent dome but are traceable continuously across the nose of its south-plunging anticlinal termination without sizable fault displacements other than by the major caldera ring faults. 
Despite the scarcity of mapped faults on the resurgent dome at Bonanza caldera, some disruption likely accompanied uplift, as at other well-studied resurgent calderas that are characterized by keystone grabens and other uplift-related faults. The apparently more limited fault disruption of caldera floor and resurgent dome at Bonanza may be related to formation of this caldera in response to a single ignimbrite eruption; the other resurgent calderas just noted are nested within earlier ignimbrite subsidence structures, and prior disruption of the subsided areas may have contributed to more complex fracturing and larger displacements during resurgence. The relatively limited faulting of caldera floor and resurgent dome at Bonanza may also partly account for the modest mineralization there, in comparison to otherwise analogous epithermal vein systems in SRMVF caldera settings such as Creede and Silverton.

Uplift of the Whale Hill dome was geologically rapid: 3.5 $\mathrm{km}$ at caldera-floor level in less than 100 k.y. (table 3), as bracketed by ages of the tilted caldera-filling Bonanza Tuff (33.12 Ma) and Porphyry Peak Rhyolite (33.03 Ma). The average resurgence rate $(3.5 \mathrm{~cm} / \mathrm{yr})$ at Bonanza caldera is roughly similar to that well constrained for uplift of the Samosir Island (Sumatra, Indonesia) resurgent dome at Toba caldera for the interval since $\sim 34 \mathrm{ka}$, declining from $\sim 4.9 \mathrm{~cm} / \mathrm{yr}$ to $<1 \mathrm{~cm} / \mathrm{yr}$, with a suggested long-term average of 2-3 cm/yr (de Silva and others, 2015).

Several tantalizing features suggest that Bonanza caldera may have resurged while deep parts of the caldera-fill ignimbrite remained hot and ductile: (1) extreme welding and rheomorphic lava-like flowage of the lower rhyolite unit (unit Tbrr) at the base of the thick intracaldera ignimbrite accumulation (fig. 11D,E); (2) down-dip trends of prolate fiamme lineations in fluidally welded ignimbrite on flanks of the dome; (3) apparently limited brittlefault disruption of caldera-floor levels in the Whale Hill dome, in comparison to complex keystone and other faults in resurgently domed calderas elsewhere; (4) lower dips in upper lavas of the caldera fill than in initially erupted lavas and underlying Bonanza Tuff, suggesting resurgence concurrently with the accumulation of these lavas as documented by isotopic ages; and (5) marginally younger sanidine ages from intracaldera Bonanza Tuff than from outflow portions (fig. 4), perhaps compatible with prolonged slow cooling deep in the intracaldera ignimbrite.

\section{An Additional Complexity}

Especially problematic to interpret has been the distinctive shattered breccia of Proterozoic granodiorite (unit p€g) and its relations to adjacent Paleozoic and Tertiary rocks (photo 16.1), which are well exposed along both sides of Kerber Creek near the junction with Little Kerber Creek (GG). Rotated Proterozoic blocks as much as several meters across are juxtaposed, many with only a minor matrix of pulverized granodiorite (photo 16.2). On slopes north of Kerber Creek, outcrops of granitic breccia in several zones are intermixed with float of upper Paleozoic Sharpsdale Formation (unit Ps) containing large coherent blocks of sandstone with chaotically divergent bedding orientations (photo 16.3). This area is also complicated by the presence of a structural inflection from steep dips (to near vertical) in both Paleozoic and Tertiary volcanic rocks to the east, on the southwest flank of the Sand Gulch anticline, to gentler attitudes in volcanic rocks west of the breccias. Alternative interpretations might include (1) thrust-fault breccias, (2) late-Paleozoic talus deposits, (3) caldera-ring-fault shatter breccias, and (4), most plausible as inferred here, calderacollapse landslide deposits.

Thrust-fault breccias. The brecciated Precambrian granodiorite was interpreted as lying within a zone of prevolcanic (Laramide) thrusting by Burbank (1932, p. 40-41, plate 3), but no obvious evidence exists for a thrust contact. Fault planes, slickensides, discrete zones of finely comminuted microbrecciated rock, or other evidence of low-angle faulting are absent.

Late Paleozoic talus deposits. Near margins of the main breccia mass (for example, GG, lat $38^{\circ} 12.94^{\prime}$ N., long $106^{\circ} 4.58^{\prime}$ W. or lat $38^{\circ} 12.92^{\prime}$ N., long $106^{\circ} 4.57^{\prime} \mathrm{W}$.), matrix-supported granodiorite clasts are surrounded by arkosic sand (photo 16.2), rather similar in appearance to some beds in the upper Paleozoic Sharpsdale Formation (unit Ps). These textures might suggest an origin as paleo-talus adjacent to steep slopes formed during Ancestral Rocky Mountain deformation (Pennsylvanian), but petrographic and chemical data show that the matrix is derived mainly from crushed granodiorite. Modestly higher $\mathrm{SiO}_{2}, \mathrm{FeO}$, $\mathrm{MgO}$, and related trace elements in the breccia matrix (table 5) suggest that quartz and heavy minerals have been concentrated relative to feldspar, compared to the protolith, but compositions remain distinct from the quartz-rich Sharpsdale Formation. Additionally, no coherent beds of Sharpsdale-type sediment onlap or interleave with the granodiorite breccia. Instead, broad zones contain large blocks of Sharpsdale sedimentary rocks with divergent orientations, unlike typical exposures of the Sharpsdale Formation elsewhere, which crop out on steep slopes or break down readily into small fragments of scree where outcrops are lacking. Measurable attitudes on outcrop-size blocks of the Sharpsdale scatter widely but tend preferentially to strike northwesterly with steep dips, perhaps reflecting influence from the nondisrupted southwest flank of the Sand Gulch anticline just to the east.

Caldera-ring-fault shatter breccias. The location of the brecciated Proterozoic rocks, immediately adjacent to the main caldera-collapse ring fault that occupies the valley of Kerber Creek, could suggest a possible origin as highly shattered wall rocks, analogous in origin to that inferred for brecciated andesite and dacite lavas (units Trax, Trdx) that occur discontinuously adjacent to caldera ring faults farther upvalley in Kerber Creek and in Columbia Gulch (photo 11). The style of fragmentation somewhat resembles shatter breccias in the andesite to the west, but blocks of granodiorite tend to be larger and more rotated; are separated by more matrix, especially in the more easterly outcrops; and are locally mixed with other rock types. The matrix, even where it is a relatively minor proportion of clast-supported breccia, resembles sandstone of the upper Paleozoic Sharpsdale Formation (unit Ps). In places, the breccia is matrix supported, grading continuously into sandstone that contains small angular clasts of granodiorite. Some component of shattering may be related to the Kerber Creek fault zone, but other features seem inadequately explained.

Caldera-collapse landslide deposits. At least some of the breccia must be volcanic related (photo 16.4), probably caldera associated, as indicated by locally exposed tuff matrix that encloses small blocks of the Precambrian granodiorite (lat $38^{\circ} 12.95^{\prime} \mathrm{N}$., long $106^{\circ} 4.59^{\prime} \mathrm{W}$.). The tuff is only weakly indurated (photo $16.4 A$ ) and has the composition of Bonanza rhyolite (table 5, sample 13L-1). 
A bold outcrop ( $\sim 3 \mathrm{~m}$ ) of brecciated andesite (photo $16.4 B)$ is adjacent to the rhyolite tuff that forms matrix to granodiorite clasts, although contacts between andesite and adjacent rocks are not exposed. Several even larger blocks (to $10 \mathrm{~m}$ ) of brecciated andesite (photo 16.4C) near the Soda Spring trailhead form bold outcrops surrounded by talus of Sharpsdale Formation. A smaller isolated block of brecciated andesite crops out low along the Soda Spring trail (lat $38^{\circ} 12.92^{\prime} \mathrm{N}$., long $106^{\circ} 4.51^{\prime} \mathrm{W}$.), closely confined within an area of chaotically mixed blocks of Sharpsdale sandstone (photo 16.4D), but again without precisely exposed contacts. No presentday source is available to generate these large andesite blocks by Quaternary mass wasting; lavas of biotite dacite (rather than andesitic lava) cap the west slopes of lower Soda Spring Gulch. Shattered andesite masses of this type elsewhere disaggregate into talus downslope, rather than surviving as intact large blocks during surficial downhill transport. Thus, the andesite blocks and rhyolitic tuff are interpreted as resulting from landslide processes during the Bonanza eruption and caldera collapse, similar to other megabreccia deposits that are better exposed farther upvalley.

Textural and sedimentary features within the granodiorite/ sandstone breccia also seem most plausibly interpreted as caldera landslide deposits, especially the variation from massively shattered granodiorite to intermixing of granodiorite clasts in pulverized matrix (photos 16.1, 16.2), and some hints of a stratigraphic sequence. Low along slopes near old ranch buildings (photo 15.4), abundant blocks of lithologically diverse Sharpsdale sandstone (to $1 \mathrm{~m}$ ) lie below a zone of massively brecciated granodiorite that is more erosion-resistant and holds up the prominent bench. Higher on this slope, sandstone is again the main lithology but as only small talus fragments (mostly $<10 \mathrm{~cm}$ ). The larger blocks of sandstone low on the slope, below the bench of granodiorite breccia, thus seem unlikely to have been derived by recent mass wasting from higher on this slope. Despite the absence of large sandstone outcrops, the distribution of sandstone clasts suggests the presence of at least two sandstone horizons, with the massive granodiorite breccia lying in between. Limited areas dominated by granodiorite breccia versus areas of sandstone higher on the slope hint at additional stratigraphic alternations, although these might alternatively result from an irregular upper surface on a single slide mass cored by granodiorite fragments.

Higher on the slope north of Kerber Creek junction, outcrops are lacking but float is entirely Paleozoic sandstone, without large clasts of granodiorite and consistent with a largely in place stratigraphic sequence on the west limb of the Sand Gulch resurgent anticline. A granodiorite-dominated landslide at this site would have formed early during caldera collapse, probably before emplacement of the dacitic Bonanza Tuff that caps hill $8826 \mathrm{ft}(2,690 \mathrm{~m})$ just to the east (photo 15.4). The landslide may have plowed into upper Paleozoic sedimentary rocks that floored the subsiding caldera in this area, ripping up and brecciating them; the absence of lower Paleozoic carbonates in the breccia suggests that sandstone of the Sharpsdale Formation was not carried to the depositional site as part of the landslide mass.

Farther east, along the low ridge west of lower Soda Spring Gulch (GG), small outcrops of even more diverse lithologies (andesite, upper Paleozoic sandstone, and lower Paleozoic limestone) are chaotically intermingled but without exposed tuffaceous matrix. Without man-made exposures, however, tuff matrix to caldera megabreccia is rarely exposed in the Bonanza region; only the erosion-resistant blocks crop out. A megabreccia interpretation for the Soda Spring area would provide important information on caldera-wall geology of this sector. The dominance of Proterozoic debris accompanied by only volumetrically minor clasts of upper Paleozoic sediments and Tertiary lavas suggests that paleohills of Precambrian basement stood high in the prevolcanic landscape and that volcanic cover was thin prior to eruption of the Bonanza ignimbrite. The inference of granitic caldera-collapse megabreccia in this area would also be consistent with the presence of another small area of granitic-clast megabreccia intermixed with andesite on the southwest flank of the Bonanza resurgent dome, about $2 \mathrm{~km}$ farther northwest on the ridge east of Sawmill Gulch (lat $38^{\circ} 13.72^{\prime}$ N., long $106^{\circ} 5.64^{\prime}$ W.).

An initial problem with any caldera-breccia interpretation was an outcrop map pattern suggestive of a west-dipping depositional contact along which Tertiary volcanic rocks (dacitic to rhyolitic lavas) onlapped the brecciated Proterozoic assemblage. An interpretation that the mixed granodiorite-sandstone breccia low on this slope is caldera-collapse breccia requires either that this contact be steeply depositional or a fault against the lavas along the ridge to the west. Across upper Soda Spring Gulch to the northeast, a steep contact between Paleozoic strata and Tertiary lavas also could be a candidate for a fault, but the displacement would be down to the northwest, opposite that required to account for a fault contact between the lavas and inferred caldera-landslide deposit. Thus, steep depositional contacts resulting from paleotopography seem more plausible.

Nevertheless, the origin and structural significance of the brecciated granodiorite and its relation to adjacent Paleozoic and volcanic rocks remain incompletely resolved. As a further puzzle, brecciated granodiorite crops out at similar elevations on both sides of Kerber Creek at the junction with Little Kerber Creek, precluding any substantial net displacement along this strand of the inner-caldera ring fault. This relation may be due to the large scale of resurgent uplift of the caldera floor, reversing effects of early subsidence along this segment of the ring fault.

\section{Initial and Present-Day Caldera Morphology}

A notable feature of Bonanza caldera is the geologically recent exhumation of the west side of the caldera to morphology (photos 8.2, 8.3) closely approximating its primary volcanic features (fig. 5) while concurrently exposing deep erosional levels on its eastern slopes (fig. 10; photo 14.1). By late in the Oligocene, the Bonanza caldera area was likely buried to substantial depth by continued local volcanism and by the many younger ignimbrites erupted from farther southwest in the San Juan region. More recently, tilting related to younger Rio Grande rift extensional faults and deep erosion into the rugged present-day landforms have exposed the interior of the caldera at levels from Precambrian basement, through a thick sequence of Paleozoic sedimentary rocks, precaldera intermediate-composition lavas, the entire section of intracaldera tuff, overlying postcaldera lavas, and associated resurgent intrusions.

Despite the later depositional, erosional, and structural complexities, parts of the present-day topography have been exhumed to features broadly similar to those of the Oligocene caldera. 
These include the high present-day topographic crest of the Whale Hill resurgent dome (fig. 16), even though almost entirely stripped of intracaldera Bonanza Tuff; the entire $\sim 3.5 \mathrm{~km}$ thickness of caldera-filling tuff and postcollapse lavas on the west flank of the dome (fig. 14A); the valleys of Kerber and Slaughterhouse Creeks that coincide broadly with an original moat between the inner wall and flank of the resurgent uplift (fig. 5); and the high western ridge of Antora Peak (13,269 ft), Windy Point (11,900 ft), Flagstaff Mountain (12,072 ft), and farther south (BZ) that coincides closely with the original topographic rim of the caldera (8.2). Although more modified by erosion, the continuation of high ridges southeast across Ute Pass to Saguache Peak (10,550 ft) and then eastward into Noland Gulch (GG) seems likely to represent further approximations of the caldera rim (figs. 5, 10). The caldera elements viewed up Kerber Creek valley, from near Parkville (GG) toward Antora Peak (cover photo), appear broadly similar to those after completion of the Bonanza caldera cycle, except perhaps that the caldera-moat valley would have been largely filled by postcollapse lavas and volcaniclastic rocks. Thus, the morphology on the western side of Bonanza caldera is broadly comparable to younger San Juan calderas such as Creede and Cochetopa Park, where later Cenozoic erosion has exhumed Oligocene caldera morphology that is even more completely preserved (Steven and Ratté, 1973; Steven and Lipman, 1976; Lipman and McIntosh, 2008).

Large segments of the west caldera rim are still capped by thick Bonanza Tuff (photo 9.4A), although these west-dipping exposures may mainly represent high remnants of caldera-filling ignimbrite, ponded between the ring-fault zone and the upper caldera wall that had been enlarged by landsliding during caldera collapse (caldera-collar volume of Lipman, 1997). When the geometry of these ignimbrite remnants is corrected for their 10-20 $0^{\circ}$ westward dips, they appear as westward-thinning scabs, banked against older intermediate-composition lavas of the Rawley complex high on the inner caldera wall. Similar highfill remnants of intracaldera ignimbrite, preserved as continued subsidence dropped the central caldera floor to greater depths, are present at other San Juan calderas such as Lake City and Creede (Lipman, 1976a; Lipman, 2000, figs. 12, 13).

In contrast, the eastern Bonanza caldera is exposed at much deeper levels, and accordingly less of the caldera morphology is preserved. Only a few small scabs of intracaldera tuff have survived erosion on the southeast flank of the Whale Hill dome, and erosion has widely cut through the precaldera lavas of the caldera floor down into Paleozoic rocks and Precambrian basement rocks that are intruded by the granodiorite to granitic plutons inferred to have caused resurgent uplift (photo 14.1).

The east margin of Bonanza caldera is largely concealed beneath alluvial fill of the San Luis Valley in the northern Rio Grande rift. However, any geometrically simple arcuate projection of the Kerber Creek ring fault and the morphologic topographic rim suggests that the original east caldera margin lay close to the frontal bounding fault of the present-day Sangre de Cristo Mountains from south of Poncha Pass to east of Villa Grove (fig. 5). Particularly important for interpretation of the eastern extent of Bonanza caldera are exposures at Round Hill (PO), within the northern San Luis Valley, surrounded by sedimentary fill of the Rio Grande rift. At this site, sanidine-bearing dacite lava appears to lap unconformably against Proterozoic metamorphic rocks to the east, along an arcuate west-dipping contact without intervening older volcanic rocks (photo 8.4). A caldera-fill origin for the dacite, wedging out low against the inner Bonanza wall, is supported by a sanidine ${ }^{40} \mathrm{Ar} /{ }^{39} \mathrm{Ar}$ age of $33.02 \pm 0.01 \mathrm{Ma}$, just younger than the weighted-mean age of the Bonanza Tuff (33.12 $\pm 0.02 \mathrm{Ma})$. This age for the dacite at Round Hill is in close agreement with multiple ages from postcollapse dacite lavas and from the Porphyry Peak Rhyolite within the caldera (table 6). The presence of small phenocrysts of sanidine in the Round Hill lava is also consistent with mineral assemblages in other postcaldera Bonanza dacites (for example, unit Tbdk) but not known in older Conejos dacites from the Bonanza region. Interpretation as a small remnant of the northeast caldera wall is also favored by the presence of botryoidal travertine (unit Ttra), exposed as float on the southeast slope of Round Hill, that suggests a fossil warm-spring deposit. Alternative interpretation of this poorly exposed contact as a normal fault of the Rio Grande rift system would require an atypically arcuate and low-angle fault geometry.

In another small erosional patch between Merkt and Swidinski Creeks (PO, lat $38^{\circ} 23.62^{\prime}$ N., long $106^{\circ} 01.43^{\prime}$ W.), dacitic Bonanza Tuff and andesitic lavas lap onto Proterozoic metamorphic rocks at the base of the steep west-facing mountain front, perhaps defining a distal wedge of intracaldera ignimbrite lapping out against the east caldera wall. This patch of Bonanza Tuff low along the mountain front may have been much deeper prior to opening of the Rio Grande rift and uplift of the Sangre de Cristo Mountains. Alternatively, these small exposures might be interpreted as preserving proximal outflow of the Bonanza Tuff, if future studies were to document major rift faults farther east, higher within exposed Precambrian rocks on the west-facing slope of the Sangre de Cristo Mountains.

Combining remnants of the original topographic rim on west and south sides of Bonanza caldera with projection across the San Luis Valley to the inferred east wall against the northern Sangre de Cristo Range defines an approximate overall topographic caldera about $20 \times 25 \mathrm{~km}$ across. This topographic caldera would have been substantially larger than the structurally subsided block, because of landsliding and slumping from oversteepened inner walls (Lipman, 1997). The arcuate valley of Kerber Creek appears to follow the original morphologic moat, between the inner caldera wall and the south and west flanks of the resurgent dome, and was underlain by the main arcuate ring-fractures that accommodated caldera subsidence. To the north and northwest, both the structural boundary and the topographic rim are largely obscured by postcollapse lavas, but the presence of thick megabreccia along Clover Creek (WH) suggests that this drainage might approximate location of a structural boundary at greater depth. Projection from the better-constrained south and west sides suggests that the main ring faults bound an elliptical caldera floor roughly $15 \times 20$ $\mathrm{km}$ across. About two-thirds of this structural area is exposed at present-day levels of caldera floor; about 20 percent is covered by intracaldera ignimbrite and overlying lavas, mainly on the west side of the resurgent dome, and about 15 percent is concealed beneath sediments in the San Luis Valley.

The resulting three-dimensional preservation of morphologic, stratigraphic, and structural caldera features at Bonanza caldera includes shallow post-collapse fill and only modestly modified segments of the morphologic topographic rim and 
inner caldera walls down through the entire intracaldera-filling ignimbrite and megabreccia, to ring faults, resurgent intrusions, and prevolcanic basement, with resulting constraints on eruptive and structural evolution during a single caldera cycle. Such extensive exposure of these diverse caldera elements is unique in the SRMVF and perhaps among large Cordilleran-arc calderas associated with ignimbrite flareups elsewhere.

\section{Younger Eruptions from other San Juan Calderas (28.3-26.9 Ma)}

The Bonanza region was formerly largely to entirely blanketed by regional Oligocene ignimbrites erupted from areas to the south and west, and scattered remnants of this cover have survived erosion (photo 17.1). Intermediate-composition lavas and volcaniclastic rocks also interfinger with these ignimbrites locally within the map area (photo 17.2). The following brief sections summarize new age data and aspects of these previously studied tuffs that bear on development of Marshall and Bonanza calderas.

\section{Saguache Creek Tuff}

The Saguache Creek Tuff (unit Tsc), as named by Lipman and McIntosh (2008), is a distinctively alkalic crystal-poor rhyolitic ignimbrite $\left(72.3-75.4 \% \mathrm{SiO}_{2}\right)$ that is widely preserved in the Saguache Valley, as well as in scattered erosional remnants farther northwest (Lipman, 2012). It is especially well exposed along Saguache Creek (photo 17.3), along the west side of the Bonanza map area, where it overlies the Conejos Formation and is covered by Fish Canyon Tuff (figs. 9-10). Its distribution is roughly symmetric around its source from North Pass caldera (fig. 2) just west of the Bonanza map area, if allowance is made for more Oligocene erosion in the northwest sector and widespread cover by younger rocks to the southwest.

Major phenocrysts (3-10\% total) of the Saguache Creek Tuff are sodic low-barium sanidine $\left(\mathrm{Or}_{51} \mathrm{Ab}_{46} \mathrm{An}_{2.7} \mathrm{Cn}_{0.4}\right)$ and plagioclase; biotite is absent or extremely sparse. Otherwise similar-appearing crystal-poor rhyolitic ignimbrites of the San Juan region, such as the Sapinero Mesa and Carpenter Ridge Tuffs, contain biotite phenocrysts, have more potassic sanidine compositions (typically $\mathrm{Or}_{60-65}$ ), and have less alkalic majorand trace-element compositions (lower $\mathrm{Na}, \mathrm{Zr}$, light REE such as $\mathrm{La}$ and $\mathrm{Ce}$, and higher $\mathrm{Sr}$ and $\mathrm{Ba}$; table 4). Despite broad similarities to other crystal-poor rhyolite tuffs of the area, these details show that the Saguache Creek Tuff is compositionally unique in the San Juan region. The eruption age is tightly constrained at $32.25 \pm 0.05 \mathrm{Ma}$, from the weighted mean of six laser-fusion sanidine ${ }^{40} \mathrm{Ar} /{ }^{39} \mathrm{Ar}$ determinations from geographically diverse sites (Lipman and McIntosh, 2008; table 6).

\section{Sapinero Mesa Tuff}

The Sapinero Mesa Tuff (unit Tws), a crystal-poor rhyolite erupted from the western San Juan caldera cluster at 28.27 \pm 0.06 Ma (table 2), is among the largest ignimbrites in the San Juan region with an estimated volume of $1,000 \mathrm{~km}^{3}$ or more (Lipman and others, 1973; Bove and others, 2001). Now that the unit recognized as Saguache Creek Tuff is excluded from this ignimbrite (Lipman and McIntosh, 2008), the preserved distribution of Sapinero Mesa Tuff in the map area is confined to a northeast-trending zone from Houselog Creek to the south side of Houghland Hill (LG). In this distal area, the tuff (unit Twsn) is rarely more than $20 \mathrm{~m}$ thick, only partly welded, and light gray in color due to vapor-phase crystallization; phenocrysts are sparse, small, and more broken than in more proximal sites.

In the tributary of Houselog Creek, the tuff has a similar sanidine ${ }^{40} \mathrm{Ar} /{ }^{39} \mathrm{Ar}$ age $(28.20 \pm 0.06 \mathrm{Ma})$ and reverse paleomagnetic pole position as the Sapinero Mesa Tuff farther west (Lipman and McIntosh, 2008). This apparently distal eastern area of thin Sapinero Mesa Tuff probably was channeled to the northeast down the Saguache paleovalley, resulting in an overall distribution much like that depicted previously (fig. 10 in Steven and Lipman, 1976), even though the thick densely welded ignimbrite sheet formerly identified as Sapinero Mesa in this area is now recognized to be the older Saguache Creek Tuff.

\section{Fish Canyon Tuff}

The crystal-rich dacitic Fish Canyon Tuff (unit Tfc), erupted from the $75 \times 35 \mathrm{~km}$ La Garita caldera at $28.02 \mathrm{Ma}$ (fig. 2 ), is the most voluminous ignimbrite in the SRMVF, with a volume greater than $5,000 \mathrm{~km}^{3}$ (Lipman and others, 1970; Lipman, 2000; Bachmann and others, 2002). Seven additional large ignimbrite sheets erupted from within La Garita caldera during the next 1.1 m.y. (table 1), forming the central caldera cluster (Lipman, 2000, 2006). The northeast margin of La Garita caldera is about $30 \mathrm{~km}$ southwest of the Bonanza map area (fig. 3), and proximal Fish Canyon Tuff originally blanketed much of the northeastern San Juan region (photo 17.4), banking out locally against paleotopographic highs such as the early central volcanoes and probably including upper parts of the Rawley edifice and the Bonanza center. Within the Bonanza region, the Fish Canyon Tuff is present mainly along the paleo-Saquache Creek valley, where it forms widespread mesa caps as much as 50-75 m thick at Houghland Hill (photo 17.1) and to the west (LG). Small erosional remnants are also preserved in upper Middle Creek and along the Continental Divide $(\mathrm{CH})$, at elevations as high as 10,800 $\mathrm{ft}(3,300 \mathrm{~m})$.

\section{Carpenter Ridge and Wason Park Tuffs}

The Carpenter Ridge Tuff (unit Tcr), another $>1,000-\mathrm{km}^{3}$ ignimbrite erupted at 27.55 $\pm 0.05 \mathrm{Ma}$ from Bachelor caldera centrally within La Garita caldera (fig. 2), also once covered much of the northeastern San Juan region as a widespread thin sheet of densely welded crystal-poor rhyolite (Whitney and Stormer, 1985; Bachmann and others, 2014). This ignimbrite commonly contains a near-basal black vitrophyre and a central lithophysal zone, even where only a few tens of meters thick. In addition to its stratigraphic position above the Fish Canyon Tuff, the Carpenter Ridge Tuff can be distinguished in outcrop from the otherwise similar-appearing Saguache Creek Tuff by 
the presence of biotite phenocrysts. Proximal Sapinero Mesa Tuff closely resembles the Carpenter Ridge, but the distal Sapinero Mesa Tuff within the map area is only partly welded and lacks lithophysae. The Carpenter Ridge Tuff provides an important stratigraphic marker that helps distinguish faults and structures associated with eruption of the Fish Canyon Tuff from younger features formed later in conjunction with development of the Rio Grande rift.

The Wason Park Tuff (unit Tw), a crystal-rich rhyolite erupted at 27.38 $\pm 0.05 \mathrm{Ma}$ from South River caldera of the central San Juan cluster (fig. 2), ponded thickly within La Garita caldera, but it locally escaped to the northeast, following paleovalleys that breached the caldera wall. The most northeastern-known erosional remnant of Wason Park Tuff is a small area of float in the southwest corner of the Bonanza map, banked against flows of Huerto Andesite (unit Thu) on the gentle southwest slope of Spruce Mountain (southwest LG). The Wason Park Tuff at this site, about $60 \mathrm{~km}$ northeast of its source caldera rim, is still densely welded, showing that the original extent of this ignimbrite was much more widespread than present-day exposures.

Even younger regional ignimbrites of large volume, erupted from the San Luis caldera complex at 26.90 Ma (Lipman and McIntosh, 2008; Lipman, 2012), likely reached the Bonanza map area but have subsequently been entirely removed by erosion.

\section{Younger Intermediate-Composition Lavas}

Several mesa-capping erosional remnants of aphanitic to sparsely porphyritic andesitic to dacitic lava southwest of Bonanza caldera (younger lavas, fig. 4) were erupted concurrently with ignimbrites from the central San Juan caldera cluster. Flows that overlie the Fish Canyon Tuff in the vicinity of Mount Lion (LM) have yielded ages of 28.0-27.6 Ma on groundmass separates (Lipman and McIntosh, 2008). Lavas of the same sequence, across Houselog Creek to the east on the southwest flank of Spruce Mountain (LG), are overlain by a thin remnant of Carpenter Ridge Tuff (27.55 Ma), stratigraphically consistent with the isotopic results. Xenocrystic sanidine, from a flow along Mill Creek northeast of Spruce Mountain, has a high-resolution age of $27.79 \pm 0.06 \mathrm{Ma}$. These lavas are thus stratigraphically equivalent to the Huerto Andesite (unit Thu), a major unit within and adjacent to La Garita caldera to the southwest.

Mafic lavas that cap the Fish Canyon Tuff on Storm King Mountain $7.5 \mathrm{~km}$ southwest of the Bonanza map area (LO, lat $37^{\circ} 57.02^{\prime}$ N., long $106^{\circ} 24.90^{\prime}$ W.) have yielded groundmass ages $(28.00 \pm 0.14,28.14 \pm 0.13 \mathrm{Ma})$ analytically indistinguishable from the underlying Fish Canyon Tuff (28.02 Ma), and accordingly also correlate with the Huerto Andesite. Contrary to several published regional compilations (Steven and others, 1974; Cappa and Wallace, 2007), the Carpenter Ridge Tuff does not seem to be present between the Fish Canyon and overlying mafic lavas at Storm King Mountain.

Most of these localities were previously interpreted as Miocene Hinsdale Formation (Tweto, 1979; Cappa and Wallace, 2007), but only one small mesa cap of Hinsdale lava has been confirmed in the northeastern San Juan region - the flows on Houghland Hill (LG) dated at 21.81 $\pm 0.21 \mathrm{Ma}$. Capping mafic lavas nearby at Lookout Mountain (LO), also depicted as Hinsdale Formation on previous compilations (Tweto, 1979; Cappa and Wallace, 2007), have yielded a groundmass age of $33.15 \pm 0.06 \mathrm{Ma}$ that indicates these lavas are part of the undivided Conejos Formation.

\section{Regional Structure}

The Bonanza region is more structurally complex than most other sectors of the San Juan Mountains. Recognition and interpretation of the multiple episodes of faulting and other structures are complicated by heavy vegetation and limited outcrops in many areas, by lack of well-defined stratigraphy within the thick ignimbrite fills of Bonanza and Marshall calderas, by uncertain distinctions among lava sequences of multiple ages that have similar lithologies, and by difficulties in distinguishing effects of fault offsets from stratigraphic discontinuities resulting from non-planar deposition of volcanic units in deep paleovalleys.

Several unconformities along flanks of large paleovalleys in the Bonanza region appear to have been erroneously depicted as large faults on the state map of Colorado (Tweto, 1979). Examples for which the new mapping disclosed no evidence include the northwest-trending depositional contact of andesite against Proterozoic granodiorite along McIntyre Ridge (GG); the proposed continuation of the Chester fault (PP; north-trending reverse fault north of Chester townsite) southward to Tank Seven Creek, across the Continental Divide, and down the south side of Sargents Mesa $(\mathrm{CH})$; and the radial array of faults depicted near the intersection of Baxter and Tuttle Creeks with Ford Creek and Mill Gulch (northeast LMNE, northwest KM).

Faults are depicted here only where evidence for displacement is clear; my mapping has likely overlooked some structures in places where field relations were incompletely compelling. In particular, greater disruption of the resurgently uplifted core of Bonanza caldera seems likely, even though much of the complex fault pattern depicted on the map by Burbank (1932) was based on imperfect understanding of the complex lateral and vertical lithologic compositional and welding variations within the caldera-filling ignimbrite.

\section{Prevolcanic Structure}

Precambrian and Paleozoic rocks that crop out widely on east and north margins of the Bonanza map area offer important insights into the prevolcanic structural setting of the SRMVF and also provide controls on development of volcanogenic structures. These rocks define a rugged paleosurface of highlands and paleovalleys, which were recurrently partially buried and re-excavated during middle Tertiary volcanism. Some faults and folds affecting the Precambrian and Paleozoic rocks predate the volcanism; others are concurrent or younger. These complexities are in striking contrast to the gently dipping Mesozoic sedimentary rocks that semiconformably underlie the San Juan erosional remnant of the SRMVF farther to the west and south, where the Tertiary volcanic rocks overlie the northeast margin of the Colorado Plateau structural block. 
A thick sequence of lower Paleozoic carbonate and upper Paleozoic clastic rocks, on both sides of lower Kerber Creek, define a large south-southeast-plunging anticline cored by Proterozoic granodiorite, with its crest roughly along Sand Gulch (GG). This structure was well mapped and plausibly interpreted as prevolcanic by Burbank (1932, plate 3), because Tertiary volcanic rocks rest directly on Proterozoic rocks along the crest of the fold. As recognized by Burbank, the Sand Gulch anticline is asymmetric - the east flank dipping $25-35^{\circ}$, the west side dipping as steeply as $>60^{\circ}$. Because dips of the overlying volcanic strata locally are nearly as steep on the fold flanks and have a similar asymmetry as the Paleozoic strata, at least the main development of the fold must be Tertiary; it is here interpreted as part of the elongate Whale Hill resurgent dome in the core of Bonanza caldera. Because the Proterozoic rocks in the core of the anticline are directly overlain by Tertiary lavas from Sand Gulch to Cody Gulch (GG), without intervening Paleozoic sedimentary strata, this area was clearly a prevolcanic high.

The Sand Gulch anticline terminates to the south against a generally east trending system of faults that juxtapose upper Paleozoic Sharpsdale Formation against Proterozoic granodiorite. These faults can be traced from the mountain front westward at least as far as Little Kerber Creek (GG). They were described by Burbank (1932, p. 39-40, plate 3) as traces of prevolcanic low-angle thrust faults, but as discussed earlier, these faults are here interpreted as rotational structures that bound large-scale block slumps of middle Tertiary age, related to peripheral subsidence along oversteepened walls of Bonanza caldera.

In contrast, one apparently low-angle fault contact, which juxtaposes a cap of Fremont Dolomite and Harding Quartzite against underlying Sharpsdale Formation on hill 8828' (GG, lat $38^{\circ} 12.75^{\prime} \mathrm{N}$., long $106^{\circ} 00.50^{\prime} \mathrm{W}$.), seems plausibly interpreted as a thrust fault of Laramide age. Alternatively, the hill-capping strata could have slumped down the inner caldera wall along a low-angle detachment surface during caldera collapse.

A small area of low-angle faulting was inferred by Burbank (1932) near the junction of Kerber and Little Kerber Creeks (GG). Puzzling outcrops of highly shattered granodiorite, 10 $\mathrm{m}$ or more high near road level, are associated with poorly exposed arkosic sandstone of the Sharpsdale Formation. Burbank described the granodiorite as structurally overlying the sandstone and attributed its brecciation to low-angle thrust faulting. As discussed in a previous section (titled An Additional Complexity), however, no obvious evidence has been found for this interpretation. Rather, the admittedly confusing features in this area are here interpreted as landslide breccia related to caldera subsidence.

Structural relations are strikingly different in a second sizeable area of similar lower and upper Paleozoic strata that are juxtaposed against Proterozoic crystalline rocks north of Marshall Creek (PP), at the northwest margin of the map area (Olson, 1983). In this area, the sedimentary sequence dips broadly to the southeast and is truncated against Proterozoic rocks by the north-trending Chester reverse fault. Upper Paleozoic strata are deformed into a tight syncline adjacent to the fault, consistent with compressional deformation during Laramide deformation (Olson 1983, 1988; Nash, 1988). Although relations are obscured by slumping south of Marshall Creek, volcanic rocks as young as the Carpenter Ridge Tuff appear to be offset along a continuation of this structure at the pass west of Windy Peak $(\mathrm{CH})$; displacement of the volcanic rocks could be due to reactivation of the Chester fault during Miocene extension related to the Rio Grande rift.

Lower Paleozoic rocks dip steeply in a third smaller area along upper Poncha Creek (MO), where they are disrupted by north-trending faults of uncertain age. The steep dips suggest compressional deformation of Laramide age; alternatively, these could have resulted from tilting along normal faults during Miocene extension.

\section{Rio Grande Rift and Transfer-Zone Geometry}

The Rio Grande rift is a linked system of Tertiary faultbounded basins that resulted from extension along the crest of the Rocky Mountains from northern Mexico to central Colorado, including the San Luis and upper Arkansas valleys in proximity to the Bonanza region (Tweto, 1978). The sediment-filled San Luis Valley (fig. 1) is an asymmetrical graben, bounded on its east side by large-displacement normal faults at the base of the Sangre de Cristo Mountains and along much of its west side by volcanic rocks of the eastern San Juan Mountains that dip gently eastward into the graben (photo 18.1). Thickness of sedimentary fill and associated rift fault displacements decrease northward in the San Luis Valley from as much as 6,500 m (Brister and Gries, 1994) to only discontinuous remnants at Poncha Pass, and basement rocks are likely relatively shallow within the rift zone east of the Bonanza region (fig. 41 in Cappa and Wallace, 2007).

In contrast, across Poncha Pass to the north, the upper Arkansas graben has the opposite geometry, with the major riftrelated faults on its west side at the base of the Sawatch Range (fig. 1). The reversal in rift-graben asymmetry along a transfer (or accommodation) zone (Chapin and Cather, 1994) is likely responsible for some large-scale structural complexity in the Bonanza region, although in places regional rift-related structures are difficult to distinguish reliably from more localized faults related to caldera formation and other volcanic events.

The timing of initial extension in the San Luis and upper Arkansas graben remains inadequately constrained. Alignment of large ignimbrite calderas (Grizzly Peak to Bonanza) and other silicic igneous centers of the SRMVF along the Sawatch Range during the interval 38-33 Ma has suggested that these record initiation of Rio Grande rift extension (Varga and Smith, 1984; Chapin and Cather, 1994; McIntosh and Chapin, 2004). Alternatively, this alignment may have been inherited from the trends of early Tertiary Laramide uplifts. Alternatively, several features of the Oligocene volcanic centers suggest lack of regional east-west extension in the Bonanza region until later than $33 \mathrm{Ma}$ (probably later than $\sim 27 \mathrm{Ma})$. Semi-radial dike swarms at Jacks Creek volcano ( 35-34 Ma) and Tracy volcano ( 31.6- 33.5 Ma) have prominent concentrations of east-trending dikes, seemingly inconsistent with a regional stress appropriate for opening of the San Luis graben. Farther south, Summer Coon volcano (33- 32 Ma) displays an even more symmetrically isotropic distribution of radial dikes (Lipman, 1976c). In addition, several of the largest ignimbrites erupted from calderas in the San Juan region (Bonanza, 33 Ma; Fish Canyon, 28 Ma; Carpenter Ridge, 27.5 $\mathrm{Ma}$ ) spread long distances to the northeast, crossing the presentday rift zone and barrier of the Sangre de Cristo Mountains. 
Within the map area, the most significant rift-related feature appears to be the westward tilt of the entire Bonanza structural block from east of Middle Creek to the San Luis Valley (fig. 5). The westward tilt, relatively high elevations, and exposures of Precambrian basement within the Bonanza block are interpreted to constitute a diminished southern continuation of the Sawatch Range structural trend that to the north is adjacent to the upper Arkansas Valley, thus representing part of a complex broad transfer zone southward into the San Luis Valley segment of the Rio Grande rift. As much as several kilometers of apparent regional uplift and westward tilt of the Bonanza block diminish southward as rift-related displacement is transferred eastward across the Poncha Pass transfer zone, and the well-stratified volcanic sequence on Houghland Hill along the Saguache Valley (LMNE) is nearly horizontal. From the Saguache Valley southward $200 \mathrm{~km}$ into northern New Mexico, volcanic strata along the east side of the San Juan Mountains dip gently eastward into the San Luis Valley, in contrast to the westward dips in the Bonanza block and northward.

Middle Creek (LMNE, $\mathrm{CH}$ ) occupies the nearly linear hinge zone of a monocline at the west margin of the Bonanza structural block, defining an inflection along which near-horizontal volcanic units on Sargents Mesa and adjacent areas to the west rise to the east (dips $10-25^{\circ} \mathrm{W}$.). Middle Creek is notably linear all the way north to its head at the Continental Divide, but Bonanza Tuff and at least most underlying lavas show no fault displacement along this trend. Some faulting or tilting may have begun along Middle Creek during early volcanism, however, because margins of several lava sequences appear to be influenced by this alignment. These include the east flank of Jacks Creek volcano (LMNE), contrasting lithologies at the mouth of Bear Creek (especially unit Tjds to the west, versus unit Tja to the east), the east margin of the thick andesite breccia sequence (unit Tbab) that crops out west of Indian Creek $(\mathrm{CH})$, and the limited westward extent of the biotite dacite lavas (unit Trd) that cap ridges east of upper Middle Creek (CH). These juxtapositions could indicate downto-the-east offsets, or abrupt lateral facies changes, which are common in such lava sequences. Alternatively, the tilting east of Middle Creek might be due to broad resurgent uplift far beyond the topographic rim of Bonanza caldera, but the linear trend of the hinge seems more plausibly interpreted as a regional structure. Regional westward tilt of the Bonanza block could also account for some of the asymmetries of the intracaldera resurgent dome, where flank dips are $45-60^{\circ} \mathrm{W}$. on the west side, but only $15-25^{\circ}$ E. along its southeast side.

In northern parts of the map area, the Poncha Pass transfer zone includes southern segments of the major normal fault system that bounds the east side of the Precambrian-cored Sawatch Range horst (fig. 1). An apparently sizable north-northeast-trending normal fault drops Tertiary rocks down against Precambrian basement along the east flank of Mount Ouray west of O'Haver Lake (MO) and continues north beyond the Bonanza map area. Displacements decrease and trends become more irregular southward as the faults cross Poncha and Silver Creeks, apparently terminating near the northwest margin of Bonanza caldera. The irregular trends, southern termination, and absence of obvious alteration or other evidence for a major fault along the heavily vegetated southern segments suggest that, rather than just Rio Grande rift structure, these faults may have been initiated during subsidence at Bonanza caldera. Alternatively, some segments of the relatively steep contacts between Precambrian basement and Tertiary volcanic rocks may be depositional onlaps related to rugged paleotopography during the Tertiary volcanism, analogous to that more clearly exposed elsewhere in the Bonanza region, such as along McIntyre Ridge to the south (GG, HB).

Northwest of Poncha Pass, where the accommodation zone narrows to only about $5 \mathrm{~km}$ in width, the most reliable dip determinations on Tertiary units are $15-20^{\circ}$ west, continuing the structural geometry of the Sawatch block and upper Arkansas graben to the north (photo 18.2). Several rift-style normal faults have been mapped as disrupting lavas and volcaniclastic rocks of the Conejos Formation (photo 19.1), but confident interpretation of location and geometry of these structures is impeded by stratigraphic complexities and sparse outcrops. These uncertainties include the potential for complex paleotopography, such as that documented among volcanic units along Silver Creek just to the west (MO), the typically discontinuous depositional onlaps between lavas that vary greatly in thickness in short distances laterally, and difficulty in determining stratal tilts within massive lava sequences with poorly defined flow boundaries. In addition, several weakly to nonindurated volcaniclastic units of diverse age have nearly similar lithologic characteristics that impede confident distinction, especially when only mappable based on loose surface detritus. These include (1) early volcanic conglomerates in local paleovalleys, containing variable proportions of Precambrian cobbles and boulders (unit Tev); (2) various distal volcaniclastic facies of the Conejos Formation (unit Tcv), chiefly volcanic mudflow deposits containing abundant angular clasts of intermediate-composition lavas that are less indurated than in more proximal sites but also locally including cobbles of Precambrian rocks; and (3) rift-related sediments (photo 18.2) of the younger Dry Union Formation (units Tdu, Tdua).

As mapped, the complexly faulted accommodation zone northwest of Poncha Pass includes a north-northwest-trending graben that overprints an east-northeast-trending horst of Conejos lavas and volcaniclastic rocks (units Tca, Tcap, Tcv). However, several bounding contacts, especially those between the Conejos and Dry Union Formations (units Tdu, Tdua) could alternatively be interpreted as depositional. Especially problematic is the south boundary of lavas on the horst, mapped as faulted to the west as far as Silver Creek but seemingly overlain depositionally by Dry Union sediment farther east, near Poncha Pass (PO). The nearly linear contact between Precambrian basement and volcaniclastic Conejos rocks on the west side of the canyon, followed by Hwy 285 north from Poncha Pass, is depicted as depositional and dipping moderately steeply westward, but alternative interpretation as a fault seems possible.

Also uncertain are the nature of some mapped contacts between the upper facies of the Dry Union Formation and older rocks: fault, depositional, or onlap concealing a pre-existing fault. Some faults appear to displace volcanic rocks but not the upper boulder-conglomerate facies of the Dry Union Formation (unit Tdup). For example, along upper Beaver Creek (MO), volcanic units of the Conejos Formation appear to be downfaulted against Precambrian rocks, but the upper boulder conglomerate (unit Tdup) laps onto meta-arkose (unit p€m) on the upthrown northwest side of the fault without apparent 
substantial offset. As another problematic example, a northeasttrending belt of bouldery Dry Union Formation, mapped as depositionally covering a steep unconformity between the Tertiary lava sequence and the Proterozoic rocks on the north side of Poncha Creek west of the Shirley townsite (MO), could onlap a concealed fault or even possibly be in fault contact with the Proterozoic. Either fault alternative seems difficult to reconcile, however, with the exposed distribution of volcanic rocks adjacent to the belt of Dry Union Formation.

Other structures, which are likely associated with development of the rift zone and the transfer zone centered on Poncha Pass at the north margin of the map area, include north-trending faults that drop volcanic rocks against Proterozoic granodiorite along Murphys Hole west of Round Hill (PO); perhaps northerly faults that repeat slices of Paleozoic sedimentary rocks in upper Poncha Creek (MO); and northwest-trending faults largely concealed by surficial deposits in San Luis Valley, including the Villa Grove zone that records Quaternary displacement (McCalpin, 1982; Cappa and Wallace, 2007).

Relatively few faults of large magnitude that are clearly rift related are exposed in the Bonanza region south of the Poncha Pass transfer zone. One candidate is the large-displacement steep fault that places Tertiary volcanic units against Precambrian rocks from north of Turquoise Gulch (WH) to the south toward Kerber Creek (photo 19.2) and, perhaps, arcing eastward to connect with a large offset between Paleozoic strata and Precambrian rocks along Clayton Cone (VG). The down-to-the-west displacement is antithetic to the graben structure of the San Luis Valley, however, and the concave-eastward arcuate geometry is parallel to the trend of the elliptical Whale Hill resurgent dome, suggesting possible alternative origin as a flank fault of this structure.

\section{Alteration and Mineralization}

Large areas of volcanic rocks in the Bonanza map area were affected by intense propylitic, argillic, and acid-sulfate alteration, especially in proximity to subvolcanic intrusions. In this study, major areas of supergene oxidation have been depicted on the geologic map, especially where alteration has been sufficiently severe to impede reliable identification of volcanic rock types, but no detailed study of alteration mineralogy or processes has been undertaken. Fine-grained propylitic alteration and metamorphism (albite-epidote-chlorite) are widespread in lavas of the Rawley complex and overlying Bonanza Tuff where exposed at deep levels within Bonanza caldera, likely recording high thermal gradients above and adjacent to intracaldera intrusions. Disseminated pyrite adjacent to some intrusions has also generated intense supergene leaching that can obscure original volcanic lithologies. Interiors of intrusions typically are less altered than their country rocks at Bonanza. This is in contrast to extreme alteration within several small intrusions in the Cochetopa Park area to the west that were loci for more intense alteration than adjacent country rocks (Lipman, 2012).

Exploration for metallic minerals has mainly been in the Bonanza mining district, on the west flank of the resurgent dome; in addition, turquoise has been mined along the margin of an east-side caldera intrusion at Peterson Creek (WH). Minor exploration has also been undertaken in altered areas adjacent to outlying intrusive centers at the Klondike Mine and Spook City (KM), on the southwest flank of Bonanza caldera.

\section{Bonanza Mining District}

Many base-precious-metal veins and prospects have been explored in the Bonanza district, with production starting in the 1880s. The rich ore was depleted quickly, but low-grade ore was mined intermittently until the 1970s. The early investigations by Patton (1916) and Burbank (1932) remain the only comprehensive studies of ore deposits in the Bonanza district. Few mines were accessible at the time of Burbank's investigation, and none have been open in recent years. No detailed ore-deposit investigations were undertaken during this volcanology-focused study. The following summary is partly modified from Bethke (2011) and Cappa and Wallace (2007).

The Bonanza district is characterized by numerous small mines, most of which have generally produced fewer than 1,000 tons of ore. Patton (1916) listed 47 mines that produced ore between 1881 and 1900, and Burbank added 21 producers through 1930, the end of significant mining in the district. The Rawley Mine (photo 20.1), the largest in the district, was developed over a vertical range of 1,200 ft, including a 6,200-ft-long drainage and haulage tunnel to Squirrel Gulch. Through 1970, the Bonanza district produced just over $\$ 11.5$ million in gold, silver, copper, lead, and zinc (Marsh and Queen, 1974), production that would have a more recent (2012) valuation of about \$158 million (Cappa and Wallace, 2007, table 1).

In the mining district, many of the deeply buried volcanic rocks have been propylitically metamorphosed, and local acidsulfate hydrothermal alteration is widespread, along with supergene leaching of disseminated pyrite. Most ore is hosted in quartz veins, occupying fractures in andesite of the Rawley complex and in Bonanza Tuff. Burbank (1932) recognized two areas with different mineralogy in the Bonanza district. North of the town of Bonanza, the veins are relatively high in sulfides, and quartz is the principal gangue mineral. South of town, the veins are lower in sulfides, and quartz is accompanied by rhodochrosite and fluorite as principal gangue minerals. The northern area was the most productive, especially the Rawley, Cocomongo, Bonanza, and Empress Josephine Mines (photo 20.2). Mines in the southern area were less successful; only the Eagle Mine shipped a significant amount of ore. The veins tend to be of relatively short lateral extent and variable trend, probably related to the apparent scarcity of large-scale faulting in the Bonanza district. Although Burbank's mining-district map depicts an intricate mosaic of largedisplacement faults, most of these contacts are here interpreted as depositional features of stratigraphically complex caldera-fill deposits, and significant fault offsets seem to be rare.

In the 1960-1980 period, exploration drilling into the caldera resurgent dome is reported to have identified deep molybdenum mineralization (Cook, 1960; Gordon Gumble, written commun., 2006), but no production was achieved. More recently, major efforts in the district have been on mine stabilization and remediation. Acid mine drainage from workings and waste piles 
has adversely affected water quality in Kerber Creek and some of its tributaries. The primary metals of concern are $\mathrm{Zn}, \mathrm{Cu}, \mathrm{Cd}$, $\mathrm{Fe}, \mathrm{Pb}, \mathrm{Mn}$, and As. Waters draining from the Rawley Mine and its mill site have been particularly problematic. Starting in the late 1990s, ASARCO (the main recent operator) and other parties involved in mining operations in the district have undertaken a voluntary cleanup of affected land, in cooperation with local and national government agencies. As a result of these efforts, the metal content and water acidity in Kerber Creek have been lowered significantly, and its waters now support aquatic life.

\section{Villa Grove Turquoise Mine}

The Villa Grove turquoise mine (photo 20.3), along the east contact between granodiorite of the Turquoise Mine intrusion and caldera-floor andesite of the Rawley volcanic complex, was mined for copper as early as the 1890s but only developed for turquoise in 1936. This widely known deposit was developed by a pit, open cuts, and underground drifts. The turquoise is described as fracture-filling veins and nodules in the granodiorite and adjacent wall rock in felsite porphyry. The mine produced high-quality turquoise, essentially free from veining and having a sky-blue color. Peak production was in the 1940s (Cappa and Wallace, 2007); the mine is currently (2015) closed.

\section{Acknowledgments}

Successful completion of fieldwork and interpretations of the caldera history have been strongly dependent on the productive multi-year collaborative studies with William McIntosh and Matthew Zimmerer of the New Mexico Institute of Mining and Technology, principle results of which have been reported elsewhere (Lipman and McIntosh, 2008; Lipman and others, 2015). Special thanks go to Andrea Sbisà, who provided outstanding mapping assistance during many long field days in the summers of 2009-2011. Joe Colgan and Ren Thompson provided helpful technical reviews. In addition to collaboration with numerous other geologists, as noted or referenced in this report, I also thank many friends in the northeastern San Juan region who provided diverse hospitality, logistical support, help with backcountry and property access, and other assistance during fieldwork in the northeastern San Juan region. These include John and Patty Judson of Quarter-Circle Circle Ranch in Cochetopa Park; Billy, Curt, and Lee Ann Cadwell of Cathedral Creek Ranch; Robert Sharp of the Old Agency Ranch along Los Pinos Creek; and, especially for the recent years of Bonanza studies, Pip and Aaron Conrad of the Rafiki Ranch near Villa Grove, who have inspired a virtual "Rafiki Ranch Geologic Research Station" and hosted many visiting earth scientists.

\section{DESCRIPTION OF MAP UNITS}

[Locations are indicated by abbreviations (fig. 3) for 7.5' quadrangles. Photographs (for example, photo 18.2) are available separately at https://doi.org/10.3133/sim3394. For major volcanic units, phenocryst percentages are listed, with principal phases in order of abundance: bi, biotite; cpx, clinopyroxene; hbl, hornblende; pl, plagioclase; qtz, quartz; sn, sanidine. Sanidine composition includes percent (subscript): Ab, albite; An, anorthosite; Cn, celsian; Or, orthoclase. Trace elements: Ba, barium; Ce, cesium; La, lanthanum; Na, sodium; Nb, niobium; Sr, strontium; Th, thorium; Zr, zirconium. REE, rare earth element. Directions of magnetism in degrees: D, declination; I, inclination]

\section{SURFICIAL DEPOSITS}

[Unconsolidated deposits of diverse origin, not mapped or subdivided in detail]

Qal Alluvium (Holocene) - Silt, sand, gravel, and peaty material in valley bottoms. Locally includes small deposits of colluvium (unit Qc) and talus (unit Qt) at margins of valley bottoms

Qc Colluvium (Holocene) - Poorly sorted silt- to boulder-sized material on slopes and in steep valleys. Locally includes small alluvial, talus, landslide, and glacial-till deposits

QI Landslide deposits (Holocene) - Lobate accumulations of poorly sorted soil and rock debris on slopes marked by hummocky morphology and downslope-facing scarps. Derived from bedrock and glacial deposits. Includes small earth-flow, block-slump, and block-slide deposits. Large areas of landslide deposits in upper Kerber Creek and its tributaries are mainly remobilized glacial till (unit Qg), and contacts between these units are poorly constrained

Qf Alluvial-fan deposits (Holocene) - Generally poorly sorted material, ranging in size from silt to boulders, which grades into modern colluvium in upper parts of drainages. Only large low-angle fans are shown; smaller steep fan deposits are mapped with colluvium (unit Qc)

Qt Talus (Holocene) — Angular rock fragments as much as $1 \mathrm{~m}$ in diameter forming talus cones, talus aprons, and scree slopes. Locally well sorted. Grades into colluvium (unit Qc) as sand and silt content increases

Qfo Older alluvial-fan deposits (Pleistocene) - High-standing erosional remnants of dissected alluvial fans, consisting mainly of volcanic clasts. Merges with and in places difficult to distinguish from Dry Union Formation (unit Tdu) in northeastern map area 
Older landslide deposits (Pleistocene) — Landslide deposits in which original hummocky morphology has become subdued due to erosion and sedimentation: eroded landslide material forming high-standing erosional remnants

\section{GLACIAL DEPOSITS}

Qr Rock glacier (Holocene) - Glacier-shaped deposit of angular rock fragments on north side of Antora Peak (BZ), lacking fine-grained material on upper surface

Qm Till (Pleistocene; Pinedale glaciation) — Till of terminal and lateral moraines; thick valley-bottom till. Poorly sorted and generally unstratified clay, silt, and sand containing cobbles and boulders. Characterized by hummock or ridge topography. Some till has been mapped with colluvium (unit Qc). Contacts in upper Kerber Creek and its tributaries between moraine and widespread landslide deposits (unit QI), which mainly consist of remobilized till, are poorly constrained

\section{MIOCENE POSTCALDERA ROCKS}

Ttra Travertine (Miocene?) - Small area of scattered float of tan to yellowish-gray botryoidally laminated carbonate in small area along lower southeast flank of Round Hill (PO). Probably originated as warm-spring deposit, along fault or steep depositional contact between thick dacite (unit Tcd) and Precambrian metamorphic rocks (unit p€m)

Dry Union Formation - Erosional remnants of weakly consolidated alluvial-fan gravel and boulder deposits in sandy matrix (photo 18.2). Clasts are dominantly Precambrian crystalline rocks and intermediate-composition lavas of Tertiary age in varied proportions. Constitutes exposed fill of the Upper Arkansas and northern San Luis Valley segments of the Rio Grande rift; broadly equivalent to deposits of the Santa Fe Group to the south. Present along the eastern mountain front and at northeast margin of the map area (PO), where it is physically continuous with more widespread and better exposed deposits of this unit north of Poncha Pass (Van Alstine, 1968). Dissected high-standing fan deposits as far south as Villa Grove may be erosional remnants of this formation (photo 18.2D). Thickness, 0 to $>100 \mathrm{~m}$

Tdu Dry Union Formation, undivided-Pebbles to small boulders of mixed Precambrian crystalline rocks and Tertiary volcanic rocks, mapped mainly along slopes on south side of Poncha Pass. Distinction from early Pleistocene alluvial-fan and high-level gravel deposits (unit Qfo) becomes uncertain farther to the south

Tdup Dry Union Formation, Precambrian clasts dominant-Unconsolidated boulder conglomerate, containing clasts as much as several meters in diameter. High-energy proximal fan deposit flanking the east slopes of Mount Ouray (MO). Outcrops are lacking; distinguished from Precambrian bedrock by the scattered presence of large rounded boulders of diverse basement lithologies (photo 18.3), in contrast to the more uniform size and composition of float in poorly exposed areas of Precambrian bedrock. Abundant angular granules and larger clasts of milky vein quartz are also distinctive constituents in matrix sand of this unit, more abundant than in areas of decomposed Precambrian bedrock. This proximal upper facies of the Dry Union Formation appears to record rapid uplift and energetic erosion of the Sawatch block, after near-complete removal of Tertiary volcanic cover. It appears to be nearly unbroken by Rio Grande rift faults within the map area, or at least notably less displaced than underlying facies of the Dry Union. Alternative interpretation as exceptionally large dissected deposit of old glacial moraine derived from the prominent Devils Armchair cirque on the east slope of Mount Ouray seems less likely; comparably large and low-altitude moraine (to below 9,000', along ridge between Beaver and Grays Creeks) appears to be absent on the east slope of Antora Peak (BZ) or along other large cirque valleys of the Sawatch Range to the north

Tdua Dry Union Formation, volcanic clasts dominant-Surface rubble and rare exposures of poorly to moderately sorted conglomerate consisting mainly of andesite to dacite clasts in sandy matrix (photo 18.2). Within map area, distinguished mainly along lower Poncha Creek and its tributaries (PO), where it locally grades upward into the facies (unit Tdup) characterized by abundant boulders of Precambrian rocks. Derived mainly from andesite and dacite lavas of the Conejos Formation (units Tca, Tcd). In places, rubble containing lithologically diverse rounded clasts can be difficult to distinguish from poorly indurated volcaniclastic rocks of Oligocene age (unit Tcv), especially along ridges followed by the Rainbow Trail west of Poncha Pass (PO), and areas of abundant angular chips of fine-grained andesite can be difficult to distinguish from in-place disaggregated lava. Distinctions are further complicated in this area by local presence of sparse Precambrian cobbles in older volcaniclastic rocks (unit Tcv) that are clearly interlayered with the andesitic lavas (unit Tca), as well exposed east of O'Haver Lake (MO). This facies of the 
Dry Union is clearly displaced by some Rio Grande rift faults, although fault interpretation is uncertain in many places due to the lack of outcrop exposures and potential confusion with older volcaniclastic rocks of the Conejos Formation

Hinsdale Formation - An assemblage of silicic alkalic basalt (trachybasalt) and basaltic-andesite lavas $\left(50-60 \% \mathrm{SiO}_{2}\right)$ erupted from widely scattered vents, with volumetrically subordinate silicic rhyolite erupted as lava domes and tuffs. These rocks, emplaced intermittently between about $26.5 \mathrm{Ma}$ and $14 \mathrm{Ma}$ in the central and northeastern San Juan Mountains, constitute a bimodal volcanic suite that accompanied regional extension along the Rio Grande rift (Lipman and Mehnert, 1975)

Thb

Mafic lavas - Small erosional remnant of fine-grained dark-gray basaltic lavas $\left(50.1 \% \mathrm{SiO}_{2}\right)$ that overlie Carpenter Ridge Tuff (unit Tcr) and form the capping unit on Houghland Hill (SG, LG; photo 17.1). Sparse olivine phenocrysts, partly altered to rusty brown iddingsite, are typical; these lavas are less altered and more mafic than andesite lavas of the Conejos Formation in adjacent areas. ${ }^{40} \mathrm{Ar} /{ }^{39} \mathrm{Ar}$ groundmass age, 21.81 $\pm 0.21 \mathrm{Ma}$ on Houghland Hill; thickness 30-50 m

\section{OLIGOCENE VOLCANIC ROCKS}

Deposits of the Southern Rocky Mountain volcanic field (SRMVF; Lipman, 2007; Lipman and Bachmann, 2015), which constitute the bulk of map units in the Bonanza region. In addition to ignimbrites, lavas, and intrusions of the Bonanza and Marshall caldera cycles that are the primary focus of this study, the map area includes several eroded stratovolcanoes defined by central and radial intrusions surrounded by outward-dipping lavas (Tracy, Sargents Mesa, Rawley, Jacks Creek) that predate ignimbrite volcanism, as well as distal facies of younger ignimbrites erupted from the central San Juan caldera complex (Lipman, 2000, 2006).

\section{IGNIMBRITES AND ASSOCIATED ROCKS OF THE CENTRAL SAN JUAN CALDERA COMPLEX}

Distal remnants of several large-volume regional ignimbrite sheets, erupted from the central caldera complex (Lipman, 2000, 2006), are preserved within the Bonanza map area (fig. 9), mainly as remnants of paleovalley fills that thin and wedge out against pre-existing volcanic highlands. Intermediate-composition lavas and volcaniclastic sedimentary deposits interfinger with the regional ignimbrites locally within the map area (photo 17).

\section{Rocks Erupted from South River Caldera (27.4 Ma)}

South River caldera (fig. 2), resulting from eruption of the Wason Park Tuff, is defined by a steep caldera-wall unconformity that juxtaposes the caldera-filling South River Volcanics against flat-lying regional ignimbrites, now exhumed along the arcuate drainages of Red Mountain and Goose Creeks.

Tw Wason Park Tuff-Distinctive regional ignimbrite sheet of crystal-rich rhyolite, locally grading upward into silicic dacite (68-74\% $\mathrm{SiO}_{2} ; 15-30 \% \mathrm{pl}, \mathrm{sn}>>$ bi $>$ cpx $)$ (Ratté and Steven, 1967; Webber, 1988). Red-brown devitrified interior of cooling unit is characterized by white collapsed pumice lenses as much as $0.3 \mathrm{~m}$ long, crystallized to intergrown alkali feldspar and tridymite. More phenocryst rich and alkalic than other rhyolitic ignimbrite sheets erupted from the central San Juan region (Lipman and others, 1978); characterized by distinct tabular morphology and sodic composition $\left(\mathrm{Or}_{55-60}\right)$ of sanidine phenocrysts. Recognized within the Bonanza map area only as a small erosional remnant of loose blocks along jeep trail on the southwest slope of Spruce Mountain (LG). Weighted mean ${ }^{40} \mathrm{Ar} /{ }^{39} \mathrm{Ar}$ age (sn) for five sample sites, $27.38 \pm 0.05 \mathrm{Ma}$ (Lipman and McIntosh, 2008). Remanent magnetic polarity, reverse (D $\left.174.7^{\circ}, \mathrm{I}-16.0^{\circ}\right)$. Thickness within map area, $0->10 \mathrm{~m}$

\section{Rocks Erupted from Bachelor Caldera (27.55 Ma)}

The Bachelor caldera, entirely enclosed within central parts of La Garita caldera (fig. 2), was the source of the Carpenter Ridge Tuff, the second largest eruptive unit $\left(\sim 1,000 \mathrm{~km}^{3}\right)$ from the central caldera cluster. Distal Carpenter Ridge Tuff has been identified near Howard, Colorado, as far as $125 \mathrm{~km}$ northeast of the rim of its source caldera (McIntosh and Chapin, 2004). Thick intracaldera Carpenter Ridge Tuff, which consists dominantly of phenocryst-poor rhyolite, forms the host rocks for the economically important vein mineralization of the Creede district, within the central caldera cluster (Steven and Ratté, 1965; Lipman, 2006).

Carpenter Ridge Tuff - Widespread caldera-forming ignimbrite sheet, containing complex welding and compositional zonations (67-74\% $\mathrm{SiO}_{2}$ ), especially within Bachelor caldera (Lipman, 1975, 2000; Bachman and others, 2014). Volumetrically dominant rhyolite, containing 3-5\% phenocrysts $(\mathrm{pl}>\mathrm{sn}>\mathrm{bi}$ ), grades locally upward in proximal sites to silicic dacite (Mammoth Mountain Member), containing as much as 30\% phenocrysts. Present in western parts of the Bonanza map area as isolated small erosional remnants of rhyolite tuff, typically only partly welded. In comparison to 
otherwise similar-appearing crystal-poor rhyolite ignimbrites within the Bonanza region, bulk-sample major-element compositions are closely similar, but the Carpenter Ridge differs in trace-element contents (higher Ba, lower Nb, La, Ce, Th) from Saguache Creek and rhyolitic Bonanza Tuffs. In addition, Carpenter Ridge sanidine compositions (typically $\mathrm{Or}_{64-66} \mathrm{Ab}_{31-33} \mathrm{An}_{1.2-1.5} \mathrm{Cn}_{1.0-1.2}$ ) are more potassic than in Saguache Creek Tuff and rhyolitic Bonanza Tuff, less barium-rich than in the Sapinero Mesa Tuff. Weighted mean ${ }^{40} \mathrm{Ar}{ }^{39} \mathrm{Ar}$ age (sn) for four sample sites in the northeastern San Juan region, 27.55 $\pm 0.05 \mathrm{Ma}$ (Lipman and McIntosh, 2008). Remanent magnetic polarity, reverse

Nonwelded ignimbrite - Light-tan cavernous-weathering distal and upper parts of unit, forming distinctive vuggy outcrops of vapor-phase crystallized tuff. Mapped separately only as an isolated small knob south of mouth of Tracy Canyon (SG). Compositionally and mineralogically similar to the welded rhyolite (Tcr). Thickness, $0-15 \mathrm{~m}$

Tcr Welded rhyolite ignimbrite - Outflow sheet of phenocryst-poor tan rhyolite (Lipman and others, 1970; Whitney and others, 1988), widely characterized by black basal vitrophyre and conspicuous central lithophysal zone. Within map area, exceptionally thick (as much as $100 \mathrm{~m}$ ) on Houghland Hill (LG), along axis of paleo-Saguache Valley (photo 17.1); also preserved as small erosional remnants on southwest slope of Spruce Mountain and east of Mill Creek (LG), along East Middle Creek (CH), and south of Marshall Creek (CH). An isolated remnant of thick densely welded Carpenter Ridge Tuff occupies a paleochannel along the present-day Continental Divide at the head of Middle Creek $(\mathrm{CH})$, where it is overlain by scattered patches of Fish Canyon Tuff. Because of close proximity to large exposures of dacitic Bonanza Tuff (unit Tbd), this remnant was initially interpreted as lower Bonanza rhyolite (unit Tbrl), but trace-element distinctions confirm identity as Carpenter Ridge Tuff. Distal Carpenter Ridge Tuff has been identified near the town of Howard, along the Arkansas River $100 \mathrm{~km}$ northeast of the rim of its source caldera (McIntosh and Chapin, 2004). Thickness, 0-25 m, locally $100 \mathrm{~m}$

\section{Rocks of La Garita Caldera Cycle (28.0 Ma)}

The large La Garita caldera ( $35 \times 75 \mathrm{~km}$ across) and its eruptive products define the overall geometry of the central San Juan caldera cluster (fig. 2), all later calderas having formed within the La Garita structure (Lipman, 2000, 2006). Its associated ignimbrite sheet, the enormous Fish Canyon Tuff, which consists of monotonously uniform phenocrystrich dacite (at least 5,000 $\mathrm{km}^{3}$ ), has long been recognized as among the world's largest ignimbrite eruptions (Lipman and others, 1970; Steven and Lipman, 1976; Bachmann and others, 2002).

Huerto Andesite-Andesitic lavas and volcaniclastic rocks (Larsen and Cross, 1956; Askren and others, 1991; Parat and others, 2005) form remnants of large shield volcanoes and flanking erosional debris, mainly within and adjacent to La Garita caldera. Thickest and best developed around and within southern parts of this caldera. Compositionally similar high-level lavas within the Bonanza map area are correlated with the Huerto, on the basis of similar composition, stratigraphic position, and isotopic age; some of these flows were previously mapped as younger mafic lavas of the Hinsdale Formation (Tweto and others, 1976)

Thu Olivine andesite and hornblende andesite-dacite, undivided - Gray sparsely porphyritic olivine-bearing lavas and breccias, in places containing resorbed xenocrysts of quartz and feldspar, and lavas characterized by phenocrystic hornblende $\left(60-63 \% \mathrm{SiO}_{2} ; 15-20 \% \mathrm{pl}>\mathrm{hbl}\right.$, cpx $)$ are overlain by Carpenter Ridge Tuff on west slope of Spruce Mountain (LG). Partly resorbed sanidine xenocrysts in an andesite from Mill Creek (LG) yielded an ${ }^{40} \mathrm{Ar}{ }^{39} \mathrm{Ar}$ age of $27.79 \pm 0.06 \mathrm{Ma}$. Nearly aphyric dark vesicular andesite lavas, which lap out against dacites of the Tracy volcano on the east slope of Mill Creek (LG), appear correlative with the Huerto rocks to the west. A similar-appearing thick lava, capping a hill in upper Tracy Creek (LG), is tentatively identified as Huerto Andesite, based on comparably dark unaltered appearance in comparison to underlying andesite of the Tracy volcano (unit Tya), but alternatively might be equivalent to late andesite of the Bonanza cycle (unit Tba). Maximum thickness, 250 $\mathrm{m}$ on Spruce Mountain

Thv Bedded breccia and conglomerate-Thin locally preserved lenses of reworked crudely bedded to wellbedded laharic conglomerate, sandstone, and mudflow breccia, containing clasts of dark andesite in light-gray sandy matrix. Within study area, mappable as separate unit only on south slopes of Houghland Hill (SG). Thickness, 0-20 m

Fish Canyon Tuff - A single large cooling unit of nonwelded to densely welded gray to light-brown ignimbrite of compositionally uniform silicic dacite (66-68\% $\mathrm{SiO}_{2} ; 40-50 \% \mathrm{pl}>>\mathrm{sn}$, qtz, bi $\left.>\mathrm{hbl}\right)$. Distal Fish Canyon Tuff has been identified near the town of Howard, Colorado, along the Arkansas River $100 \mathrm{~km}$ northeast of the rim of La Garita caldera (McIntosh and Chapin, 2004) and $125 \mathrm{~km}$ south of the caldera at Las Tablas, New Mexico (Zimmerer and McIntosh, 2011). Characterized by simple welding zonation except in thick proximal sections, where compound welding is locally developed. Pumice fragments 
are obscure in many exposures of devitrified tuff, and lithic fragments typically are sparse. Densely welded tuff is massive, but upper parts commonly have slabby jointing parallel to obscure compaction foliation (photo 17.4). Rare dark pumice lenses, which lack large phenocrysts and resemble crystalpoor rhyolite in the field, contain abundant finely milled crystal fragments and are compositionally identical to the more common pumice fragments of crystal-rich dacite. Sparse resorbed pinkish quartz, accessory sphene, and hornblende without augite are distinctive phenocrysts (Lipman, 1975; Whitney and Stormer, 1985). Sanidine phenocrysts (typically $\mathrm{Or}_{72-74} \mathrm{Ab}_{23-24} \mathrm{An}_{1} \mathrm{Cn}_{1.5}$ ) are relatively potassic and conspicuously zoned, with barium (Cn) varying 1-4 mol percent (Lipman and others, 1997; Bachman and others, 2002). ${ }^{40} \mathrm{Ar} /{ }^{39} \mathrm{Ar}$ age, $28.02 \mathrm{Ma}$ (geochronologic standard, as defined by Renne and others, 1998; an alternative proposed calibration is 28.201 Ma from Kuiper and others, 2008). Magnetic polarity, normal. Maximum thickness within map area, $100 \mathrm{~m}$

Welded outflow ignimbrite sheet - Light-gray variably welded tuff, commonly forming massive rounded outcrops with columnar and sheet cooling joints. Widespread in the broad paleo-Saguache Valley along southwest side of map area (LG, LMNE; photo 17.2), but only discontinuously preserved and variable in thickness farther north because of irregular deposition and subsequent erosion along the west flank of early Tertiary Rocky Mountain uplift area. Small patches, commonly in close proximity to remnants of overlying Carpenter Ridge Tuff (unit Tcr), are preserved north of East Middle Creek, along the Continental Divide at the head of Middle Creek, and south of Marshall Creek along the quadrangle boundary $(\mathrm{CH})$. A black basal vitrophyre is atypically well developed in cliffs along lower Houselog Creek (LG). Where in close proximity to the older but lithologically similar Badger Creek Tuff (unit Tbc) along Marshall Creek $(\mathrm{CH})$, the Fish Canyon Tuff is characterized by fewer lithic fragments and by smaller pumice lenses that are more completely devitrified. Distal Fish Canyon Tuff has been identified near the town of Howard, Colorado, along the Arkansas River 100 km northeast of the rim of La Garita caldera (McIntosh and Chapin, 2004) and $125 \mathrm{~km}$ south of the caldera at Las Tablas, New Mexico (Zimmerer and McIntosh, 2011). Thickness, 0-125 m

Tfen Nonwelded to partly welded ignimbrite-Light-gray weakly indurated tuff, commonly poorly exposed along basal and upper parts of the ignimbrite sheet. Sufficiently large in outcrop area to map separately only on slope north of Bear Creek (LMNE). Thickness, 0-20 m

\section{Local Volcaniclastic Rocks of Saguache Paleovalley}

Tsav Andesitic conglomerate - Thin locally exposed lenses of reworked crudely to well-bedded laharic conglomerate, sandstone, and mudflow breccia, containing clasts of dark andesite in light-gray sandy matrix. Exposed beneath Fish Canyon Tuff and above distal Sapinero Mesa Tuff along south and southeast slopes of Houghland Hill (LG). Distinguishable from older volcaniclastic units, such as distal debrisflow deposits of Buffalo Pass Campground (unit Tdc), only by stratigraphic position. These axial deposits constitute continuation of stream deposition in the Saguache paleovalley, which earlier had generated similar conglomerate units (units Tdc, Tlav), separated by eruption of several lava and tuff units. Thickness, $0-15 \mathrm{~m}$

\section{Older Ignimbrite Related to Western San Juan Calderas (28.3 Ma)}

Distal facies of several regional ignimbrite sheets erupted from western San Juan sources (Lipman and others, 1973; Steven and Lipman, 1976; Bove and others, 2001) are exposed discontinuously north and east of the central caldera cluster (Steven and Hail, 1989; Lipman, 2012). These include three lithologically similar phenocryst-poor rhyolite ignimbrites (Blue Mesa, Dillon Mesa, and Sapinero Mesa Tuffs). Only thin distal parts of the Sapinero Mesa Tuff, erupted from the composite Uncompahgre-San Juan caldera (Steven and Lipman, 1976), are present within the Bonanza map area (fig. 9).

Twsn Sapinero Mesa Tuff - Weakly indurated gray to tan distal rhyolitic ignimbrite sheet $\left(72-74 \% \mathrm{SiO}_{2} ; 3-5 \%\right.$ $\mathrm{pl}>\mathrm{sn}>\mathrm{bi}$ ), commonly vapor-phase crystallized. Typically thin, discontinuously preserved, and exposed within map area mostly as slope-mantling debris along Houselog Creek and south slopes of Houghland Hill (LG). Where thickest (west of Bonanza map area), contains a well-developed central lithophysal zone (as much as 10-20 m thick), similar to that in the Carpenter Ridge Tuff. Distinguished from lithologically similar Carpenter Ridge Tuff (unit Tcr) by stratigraphic position relative to Fish Canyon Tuff and by locally distinct welding and crystallization textures. Distinguished in field by presence of sparse biotite phenocrysts from otherwise similar-appearing Saguache Creek Tuff (unit Tsc); also contains more potassic and barium-rich sanidine (average, $\mathrm{Or}_{61} \mathrm{Ab}_{33} \mathrm{An}_{2} \mathrm{Cn}_{4}$ ). Partly welded distal outcrops distinguished in field from similar-appearing tuff of Big Dry Gulch (unit Tbg) by presence of sanidine. ${ }^{40} \mathrm{Ar} /{ }^{39} \mathrm{Ar}$ age (sn), 28.20 $\pm 0.06 \mathrm{Ma}$, in Houselog Creek. Magnetic polarity, reverse: D $116.1^{\circ}, \mathrm{I}-65.4^{\circ}$ in Houselog Creek. Maximum thickness, $25 \mathrm{~m}$ 
The Conejos Formation is a broad stratigraphic unit encompassing thick sequences of dominantly andesite and dacite as lavas and proximal breccias that were erupted from central volcanoes, surrounded by voluminous aprons of volcaniclastic debris emplaced as mudflow and stream-fan deposits. These lavas, breccias, and associated intrusions, which constitute the volumetric bulk of the volcanic deposits in the San Juan region, were erupted from widely dispersed central volcanoes prior to inception of ignimbrite activity and associated caldera formation throughout the San Juan Mountains (Lipman and others, 1970; Steven and Lipman, 1976; Colucci and others, 1991; Lipman, 2000). Ignimbrites in the northeastern San Juan region are older than those to the south and west, however, and interfinger complexly with rocks equivalent in age to the Conejos Formation as mapped elsewhere (fig. 9). Subsequently deeply eroded, some of these early effusive deposits are now discontinuously exposed as surviving topographic highs along margins of the ignimbrite calderas; others are preserved as postcollapse caldera-fill assemblages.

Compositional subunits among Conejos lavas have been mapped in varying detail regionally, depending on local diversity, quality of exposures, and mapping scale. Over much of the San Juan region, such Conejos rocks are as young as $30 \mathrm{Ma}$, but in the northeastern San Juan region large older ignimbrites such as the Bonanza Tuff (33.1 Ma) and Saguache Creek Tuff (32.2 Ma) interfinger with rocks that would elsewhere be included within an undivided Conejos Formation (fig. 9; Lipman and McIntosh, 2008; Lipman, 2012). In addition, rocks of Conejos age are more compositionally diverse in the northeastern San Juan Mountains: proximal lavas tend to become more silicic upward, and biotite-bearing dacite and low-silica rhyolite are especially abundant in the vicinity of Bonanza caldera.

As a result, for the Bonanza map area and in the adjacent Cochetopa and North Pass caldera areas to the west, the Conejos Formation has been mapped and subdivided in more detail than elsewhere in the San Juan region. The broadly defined Conejos assemblage has been subdivided into stratigraphic packages (upper, intermediate, lower units) where separated by regional ignimbrite sheets that provide age control (fig. 9). Thick caldera-fill lava assemblages within and adjacent to the North Pass, Bonanza, and Marshall calderas are mapped as phases of these caldera cycles, while recognizing that, without the ignimbrite association, these rocks would readily be included within an undivided Conejos Formation. In addition, several large precaldera central volcanoes of the Conejos Formation have been assigned separate map designations, including the Jacks Creek, Rawley, Sargents Mesa, and Tracy centers.

Locally erupted lavas and tuffs that overlie the Saguache Creek Tuff and other units of the North Pass caldera cycle have been separated as upper units of the Conejos Formation (Lipman, 2012). These diverse rocks are stratigraphically equivalent to upper parts of the Conejos Formation farther west and south in the San Juan region, where lower Oligocene ignimbrite sheets that provide regional stratigraphic marker horizons are absent. Some of these rocks may represent prolonged late activity of the North Pass caldera cycle; others likely are local expressions of continuing regional flux of intermediate-composition eruptions, unrelated to any specific ignimbrite-caldera cycle.

Tla Andesite of Lone Tree Gulch (Saguache Valley) - Several dark-gray lavas of sparsely porphyritic vesicular andesite $\left(59 \% \mathrm{SiO}_{2}\right)$ in lower Houselog Creek (LG) and north of Saguache Creek (southwest corner of LMNE) are locally preserved between the tuff of Big Dry Gulch (Tbg) and overlying Fish Canyon Tuff (unit Tfc) along the axis of paleo-Saguache Creek (photo 17.2). These rocks are more widespread west of the Bonanza map area (Lipman, 2012). ${ }^{40} \mathrm{Ar} /{ }^{39} \mathrm{Ar}$ age (groundmass plateau), $30.21 \pm 0.17$ Ma. Most individual flows are 5-10 m thick; maximum total thickness, $50 \mathrm{~m}$

Tbg Tuff of Big Dry Gulch - Nonwelded to partly welded gray-brown to red-brown dacitic ignimbrite $\left(67 \% \mathrm{SiO}_{2}\right.$; $3-5 \% \mathrm{pl}>\mathrm{bi}>>\mathrm{cpx}$ ), locally containing a black basal vitrophyre (Lipman, 2012). Exposed within map area only in small area north of Saguache Creek (southwest corner LMNE; photo 17.2). Erupted from unknown source. Forms a distinctive local marker unit, above the Saguache Creek Tuff (unit Tsc) and laharic debris-flow conglomerate (unit Tdc) and below the andesite of Lone Tree Gulch (unit Tla). Distinguished from similar-appearing Sapinero Mesa Tuff (unit Tws) by absence of sanidine, presence of sparse clinopyroxene phenocrysts, and more abundant biotite, isotopic age, and magnetic direction. ${ }^{40} \mathrm{Ar} /{ }^{39} \mathrm{Ar}$ age (biotite plateau), 30.47 $\pm 0.08 \mathrm{Ma}$. Magnetic direction, D $175.8^{\circ}, \mathrm{I}-37.6^{\circ}$. Maximum thickness, $20 \mathrm{~m}$

Debris-flow deposit of Buffalo Pass Campground - Variably fragmented poorly sorted deposit, derived largely from Luders Creek Tuff exposed in the vicinity of the present-day Continental Divide south of North Pass (Lipman, 2012). Clast size decreases, clast roundness increases, and proportion of Luders Creek Tuff decreases relative to andesitic clasts with distance eastward from source region as transport in debris flows gave way to more fluidized mudflow and stream transport. Includes megabreccia, mesobreccia, and conglomerate; only the distal conglomerate is present within the Bonanza map area. Generation process, 2 m.y. after main phases of the North Pass caldera cycle, is uncertain; perhaps emplaced in response to late structural events near concealed source for eruption of Luders Creek Tuff

Tdc Distal conglomerate-Thin locally exposed lenses of reworked crudely bedded to well-bedded stream conglomerate and sandstones along Houselog Creek (LG) contain dominant clasts of dark andesite 
and sparse clasts derived from the Luders Creek Tuff in light-gray sandy matrix. Reliably distinguished from younger volcaniclastic rocks, such as those in the andesite conglomerate (unit Tsav), only where separated by the tuff of Big Dry Gulch (unit Tbg) and (or) Sapinero Mesa Tuff (unit

Tws). Thickness, $0-15 \mathrm{~m}$

\section{CALDERA-RELATED ROCKS PREDATING THE WESTERN AND CENTRAL CALDERA CLUSTERS}

Several ignimbrites, exposed widely in the map area, erupted from northeastern sources and predate the large ignimbrite sheets erupted from the central and western caldera clusters. These ignimbrites include Saguache Creek Tuff erupted from North Pass caldera at 32.25 Ma (Lipman and McIntosh, 2008; Lipman, 2012), Bonanza (33.1 Ma) and Thorn Ranch (33.9 Ma) Tuffs erupted from Bonanza and Marshall calderas within this map area, and Badger Creek (34.1 Ma) and Wall Mountain (36.9 Ma) Tuffs erupted from calderas farther north along the Sawatch Range (figs. 1, 8). These ignimbrites have ages older than much of the Conejos Formation that has been dated farther south and west in the San Juan region, yet they overlie andesitic to dacitic lavas that are compositionally similar to the younger Conejos rocks to the south (fig. 9). Where interfingering relations with datable ignimbrites are absent, lower and upper components of the overall Conejos assemblage cannot readily be separated. The northeastern ignimbrite units also define an age and geographic progression toward early Oligocene caldera-related volcanism in central Colorado (McIntosh and Chapin, 2004; Lipman, 2007).

$$
\text { North Pass Caldera Cycle (32.2 Ma) }
$$

North Pass caldera, source of the Saguache Creek Tuff (Lipman and McIntosh, 2008; Lipman, 2012), is largely concealed beneath caldera-filling lavas and tuffs erupted from the same general area (volcanics of Cochetopa Hills, Luders Creek Tuff) and younger ignimbrites from central San Juan sources (Fish Canyon and Carpenter Ridge Tuffs). All rocks of this caldera cycle, including the precursor tuff of Spanish Creek, appear to have erupted during a brief interval at about $32 \mathrm{Ma}$. Thus, in age and geographic location, this caldera defines a transition between older ignimbrite calderas aligned north-south along the Sawatch Range, of which Bonanza at 33.1 Ma is the youngest and most southerly, and younger caldera systems located more centrally within the San Juan Mountains.

Saguache Creek Tuff - Crystal-poor rhyolite ignimbrite (named by Lipman and McIntosh, 2008), preserved widely in southwestern parts of the Bonanza map area (LMNE, northern LG; photos 12.2, 17.3A). The Saguache Creek Tuff is similar in appearance and phenocryst content to proximal Sapinero Mesa Tuff (unit Tws) to which this unit had been previously assigned in Saguache Creek and adjacent areas (Bruns and others, 1971; fig. 10 in Steven and Lipman, 1976; Olson, 1988). The Saguache Creek lacks biotite, has more sodic low-barium sanidine $\left(\mathrm{Or}_{50-51.5} \mathrm{Ab}_{45-47} \mathrm{An}_{2.6-2.8} \mathrm{Cn}_{0.5}\right)$, different trace-element bulk compositions, and is more densely welded than the distal Sapinero Mesa Tuff within the map area. It also resembles, but differs in similar ways, the upper rhyolite of underlying Bonanza Tuff (unit Tbru). Weighted mean ${ }^{40} \mathrm{Ar} /{ }^{39} \mathrm{Ar}$ age (sn) for Saguache Creek Tuff is $32.25 \pm 0.05 \mathrm{Ma}$ on determinations from six localities, significantly younger than the 33.12-Ma Bonanza Tuff (table 6). Eruption of the Saguache Creek Tuff from North Pass caldera is supported by the preserved distribution of this unit, semisymmetrically around the North Pass area where not hidden by younger rocks (to the south and west), and by stratigraphic relations with postcaldera lavas (Lipman and McIntosh, 2008; Lipman, 2012). Magnetic polarity, reverse; D $168^{\circ}, \mathrm{I}-55^{\circ}$. Thickness within map area, $0-75 \mathrm{~m}$

Tscn Nonwelded crystal-poor rhyolite - Light-gray upper and distal parts of ignimbrite sheet that are locally sufficiently thick and well exposed to be mapped separately. Thickness, 0-35 m

Tsc Partly to densely welded crystal-poor rhyolite - Variably welded light-tan to red-brown tuff (74-76\% $\left.\mathrm{SiO}_{2} ; 5-10 \% \mathrm{pl}, \mathrm{sn}\right)$. Basal black vitrophyre and central lithophysal zones (photos 17.3B,C) are locally well developed. Thickness, $0-50 \mathrm{~m}$

Tbt Bedded rhyolitic tuff - White to light-gray weakly indurated bedded tuff and sandstone. Includes reworked fluviatile, lake-bed, and aeolian deposits, as well as thin ash-fall and nonwelded ignimbrite deposits (photo 17.3A). A recent ${ }^{40} \mathrm{Ar} /{ }^{39} \mathrm{Ar}$ determination (M. Zimmerer, written commun., 2016) shows that sanidine grains in the bedded ash have a restricted age range, with a weighted mean (32.24 $\pm 0.02 \mathrm{Ma})$, indistinguishable from that for Saguache Creek Tuff. Accordingly, the bedded tuff is interpreted as precursor surge and reworked deposits associated with eruption of this ignimbrite. Exposed below Saguache Creek Tuff mainly along Lone Tree Gulch (southwest LMNE). Thickness, 0-25 m

\section{Rocks of the Bonanza Caldera Cycle (33 Ma)}

Bonanza caldera, source of the compositionally diverse Bonanza Tuff, provides exceptional exposures of deep structures and depositional processes that accompany large-scale explosive eruptions. The caldera occupies much of the Bonanza map area, and outflow tuff from this eruptive center is preserved widely to the east and west (fig. 12). The 
caldera collapsed during the ignimbrite eruption, and the associated ignimbrite (Bonanza Tuff) is ponded to a thickness of as much as $2.5 \mathrm{~km}$ within the caldera. After the ignimbrite eruption, compositionally diverse lavas varying from andesite to high-silica rhyolite filled the caldera to overflowing and spread across adjacent slopes. Intrusions of intermediate-composition to aplitic granitic rocks arched the caldera floor into a steep-sided elliptical resurgent dome, within a few hundred-thousand years after eruption of the Bonanza Tuff. Caldera resurgence, rift-related tilting, and deep erosion into the rugged present-day landforms have exposed the interior of Bonanza caldera at levels from Precambrian basement through a complete Paleozoic sedimentary sequence, precaldera intermediate-composition lavas, the entire section of intracaldera tuff, overlying postcaldera lavas, and associated resurgent intrusions. The resulting three-dimensional caldera exposures are unique in the Southern Rocky Mountain volcanic field (SRMVF).

Granitoid intrusions - Several intrusions occupy an elliptical area about 5 x $10 \mathrm{~km}$ centrally within Bonanza caldera (fig. 10); compositions are diverse, varying from aplitic granite to fine-grained granodiorite and diorite, along with intrusive andesite and dacite (photo 14). These intrusions are exposed along the core and east flank of the resurgently domed caldera floor (photo 14.1) and likely constitute upper parts of larger plutons that caused the resurgence. Several isolated smaller bodies of similar composition and texture intrude the west flank of the resurgent dome, within the Bonanza mining district

Spring Creek intrusion-Pluton of light-colored granite about $3 \times 4 \mathrm{~km}$ at exposed levels in upper Spring Creek (WH). Margins of aplitic granite and rhyolite porphyry, especially along roof contacts, grade to coarser granite in pluton interior. Previously, briefly noted as "Spring Creek rhyolite" (Varga and Smith, 1984). Near-horizontal roof contacts of the pluton are intrusive into precaldera andesite (unit Tra) on the east flank of Whale Hill at elevations as high as 11,800 $\mathrm{ft}(3,600 \mathrm{~m})$. Probable continuity with a larger granitic pluton at shallow depth is suggested by a small exposure of porphyritic granite (unit Tag) of similar age, $1 \mathrm{~km}$ to the north in upper Alder Creek. A miningexploration drill hole near Round Mountain, $3 \mathrm{~km}$ to the west, reportedly penetrated granite at a depth of less than 1,000 m (R.J. Varga, written commun., 2008), indicating that granitic intrusive rocks are more widespread in the shallow subsurface within the core of Bonanza caldera

Tas Aplitic granite - Light-gray porphyritic aplite and rhyolite porphyry containing 5-15\% phenocrysts of K-feldspar and quartz, exposed mainly as talus on steep slopes (photo 14.3A) along pluton margins (74.4-77.6\% $\mathrm{SiO}_{2}$; phenocrysts of $\mathrm{K}$-feldspar as much as $1 \mathrm{~cm}$ long, $\mathrm{Or}_{51.5} \mathrm{Ab}_{47} \mathrm{An}_{1.4} \mathrm{Cn}_{0.15}$ ). The K-feldspar phenocrysts are microperthitic, precluding precise compositional determination by electron-probe analysis. Two ${ }^{40} \mathrm{Ar} /{ }^{39} \mathrm{Ar}$ ages (K-feldspar) from aplite phases are $33.26 \pm 0.07$ and $33.30 \pm 0.09 \mathrm{Ma}$

Tgs Porphyritic granite - Central area of medium-grained porphyritic granite (K-feldspar, plagioclase, quartz, biotite) poorly exposed as scattered rounded boulders on heavily vegetated slopes $(72.6 \%$ $\mathrm{SiO}_{2}$; phenocrysts of $\mathrm{K}$-feldspar as much as $2 \mathrm{~cm}$ long, $\mathrm{Or}_{59} \mathrm{Ab}_{40} \mathrm{An}_{1.1} \mathrm{Cn}_{0.2}$ ). An age of 34.36 \pm 0.07 $\mathrm{Ma}$ on K-feldspar from the interior granite, older than those from the aplitic granite, is probably related to non-uniform distribution of potassium in microperthite and excess ${ }^{40} \mathrm{Ar}$ in the largest domains (Foster and others, 1990). Plutonic K-feldspar from Questa (Zimmerer and McIntosh, 2012a) and Mount Aetna calderas (Zimmerer and McIntosh, 2012b), similarly exposed caldera systems in the SRMVF, also contains significant excess ${ }^{40} \mathrm{Ar}$

Tag Porphyritic granite of Alder Creek-Small area of fine-grained porphyritic granite $(72.3 \% \mathrm{SiO} ; \sim 10 \%$ phenocrysts of K-feldspar as much as $5 \mathrm{~mm}$ across), exposed as talus near head of south fork of Alder Creek (WH). $\mathrm{A}^{40} \mathrm{Ar} /{ }^{39} \mathrm{Ar}$ age (K-feldspar) is $33.02 \pm 0.12 \mathrm{Ma}$. The exposed granite is surrounded by a broad halo of intensely altered andesite (unit Tra), suggesting that the intrusion is larger at shallow depth

Turquoise Mine intrusion-Texturally variable light-gray granodiorite and darker intrusive andesite form a composite intrusion about $3 \times 7 \mathrm{~km}$ across (photo 14.1), extending from the head of Peterson Creek, across several drainages to the southwest, at least as far as the southeast ridge of Hayden Peak (WH). Designated the Turquoise Mine intrusion by Lipman and others $(2013,2015)$. A coarse mafic facies $\left(55.17 \% \mathrm{SiO}_{2}\right.$, table 4$)$ of this texturally diverse intrusion has been called the "Turquessa Gabbro" (Varga and Smith, 1984; Cappa and Wallace, 2007), but no petrographic descriptions or chemical data were previously available. The Villa Grove Turquoise Mine (Cappa and Wallace, 2007) was developed in altered precaldera andesite (unit Tra), along the east contact of this intrusion, and the widespread extent of intensely altered country rock suggests that the intrusion is much larger at shallow depth Granodiorite - Granodiorite phases of the intrusion (photos 14.2A,B) vary from equigranular to finely porphyritic (two analyses: $62.4-67.0 \% \mathrm{SiO}_{2}$ ), consisting mainly of plagioclase, biotite, chloritized pyroxene, and small interstices of quartz and alkali feldspar. A coarsely dioritic phase along Peterson Creek is more mafic $\left(55.2 \% \mathrm{SiO}_{2}\right)$. A fine-grained aplitic granodiorite yielded ${ }^{40} \mathrm{Ar} /{ }^{39} \mathrm{Ar}$ ages (whole-rock) of $32.80 \pm 0.22 \mathrm{Ma}$ (plateau) and $31.91 \pm 0.28 \mathrm{Ma}$ (isochron) 
Intrusive andesite - Andesitic phases of the intrusion (photo 14.2C) are relatively unaltered dense dark-gray rocks that form bold outcrops. They are characterized by closely spaced rectilinear joints, in contrast to adjacent precaldera andesitic lavas that fracture more irregularly, are less dense, are vesicular in places, and are widely affected by greenish-gray propylitic metamorphism and supergene alteration. Such distinctions between andesitic lava and intrusion remain ambiguous, both for the Turquoise Mine body and other fine-grained texturally variable intrusions such as at Tracy Creek volcano (unit Tyia). The intrusive andesite (three analyses: $54.1-55.9 \% \mathrm{SiO}_{2}$ ) is similar in composition to the dioritic phase of the associated granodiorite (unit Ttg). In places, andesite grades imperceptibly into fine-grained diorite or granodiorite, in others, contacts are sharp. Many scattered small andesite bodies are exposed south and southwest of the central intrusive locus marked by the granodiorite; some of these could be older intrusions associated with precaldera growth of the Rawley volcanic complex. An intrusive andesite along the ridge between Peterson and Kelly Creeks (WH) yielded ${ }^{40} \mathrm{Ar} /{ }^{39} \mathrm{Ar}$ ages (whole-rock) of $33.06 \pm 0.21 \mathrm{Ma}$ (plateau) and 32.83 $\pm 0.21 \mathrm{Ma}$ (isochron). Andesite of the Turquoise Mine intrusion is in contact with the aplitic granite of Spring Creek along the heavily vegetated divide between Peterson and Spring Creeks (WH), but exposures are inadequate to determine relative ages among these intrusions the southwest flank of the intracaldera resurgent dome. Mafic porphyritic granodiorite-diorite $(56.1 \%$ $\mathrm{SiO}_{2}$ ) with relatively coarse textures intrudes caldera-floor andesite along a ridge in upper Elkhorn Gulch (WH). Late-crystallized interstitial K-feldspar that is unaltered and 3-4 mm across yielded ${ }^{40} \mathrm{Ar} /{ }^{39} \mathrm{Ar}$ ages of $33.38 \pm 0.08 \mathrm{Ma}$ (plateau) and $33.32 \pm 0.05 \mathrm{Ma}$ (isochron). A tiny area of similarappearing granodiorite $\left(55.7 \% \mathrm{SiO}_{2}\right)$, first noted by Patton $(1916$, p. 54$)$, is exposed only as obscure concentrations of boulders near the contact between basal Bonanza Tuff and underlying andesite along the north side of Rawley Gulch (BZ). This locality yielded K-feldspar ${ }^{40} \mathrm{Ar}{ }^{39} \mathrm{Ar}$ ages of $33.02 \pm 0.08$ $\mathrm{Ma}$ (plateau) and $33.03 \pm 0.08 \mathrm{Ma}$ (isochron). A dike along the ridge east of Greenback Gulch (WH) is somewhat more silicic $\left(58.9 \% \mathrm{SiO}_{2}\right)$, but the interstitial $\mathrm{K}$-feldspar was too fine-grained to permit an isotopic age determination. These small areas of granodiorite are close to basal contacts of intracaldera Bonanza Tuff. Although exposures are inadequate to document an age relation directly, the physical proximity, relatively coarse textures, and similarities in composition and age to the Turquoise Mine intrusion suggest that they represent small offshoots of much larger intrusions that underlie the resurgent dome of Bonanza caldera at shallow depth

Ted Eagle Gulch Dacite - A northeast-trending elongate body, about $8 \mathrm{~km}$ long, is light-tan to gray compositionally and texturally uniform dacite $\left(67.4-68.1 \% \mathrm{SiO}_{2}\right)$, initially designated "Eagle Gulch latite" (Patton, 1916; Burbank, 1932). Exposed mainly as blocky talus slopes (photo 14.3B), the Eagle Gulch Dacite contains $10-15 \%$ phenocrysts of altered plagioclase, K-feldspar, and biotite that are everywhere silicified, thermally recrystallized, and otherwise altered. These rocks locally have a fine-grained holocrystalline groundmass, but most are atypically fine grained and uniform for such a sizable body, especially in comparison to even the smallest exposed granitic intrusions on the flanks of the resurgent dome. The Eagle Gulch Dacite crops out mainly along a belt from the south side of Elkhorn Gulch to the north slope of Elkhorn Peak (WH, BZ); smaller bodies of similar appearance are present across Kerber Creek to the southwest (KM). The main Eagle Gulch exposures have the overall shape of a roughly concordant shallow tabular body, between caldera-floor andesitic lavas and basal intracaldera Bonanza Tuff. Several recent geologic maps have depicted the Eagle Gulch as lava (Tweto and others, 1976; Varga and Smith, 1984), but in agreement with the earlier conclusions of Burbank, the dacite is here interpreted as a late crudely sill-shaped intrusion. Contacts of the dacite are locally crosscutting; contact flow breccias or internal flow structures, such as characterize otherwise compositionally similar dacite lavas in the Bonanza region, are absent; and alteration is widespread, both internally and affecting adjacent rocks. Outcrops of least-altered Eagle Gulch, like other shallow intrusive rocks in the Bonanza region, tend to have massive rectilinear jointing, in contrast to more closely spaced irregular fractures and granular groundmass that weathers to rounded blocks in typical lavas. Texturally similar dacite along Cottonwood Creek and the ridge to the south (WH), tentatively identified as intrusive dacite of Eagle Gulch affinity, could alternatively be a lava. Several K-feldspar dacite dikes along the northwest caldera wall, mapped as intrusions of unknown age (unit Tid), resemble the Eagle Gulch Dacite in composition and alteration character. The Eagle Gulch Dacite may constitute a southern part of the composite intrusive complex responsible for resurgent uplift of the caldera floor at Bonanza, but its sill-like geometry and fine-grained textures differ from the Turquoise Mine and Spring Creek intrusions

Intrusions of uncertain age and affinity - Fine-grained intrusive rocks in the Bonanza caldera area: mostly dikes, lacking definitive features of areal distribution, petrology, or age that permit confident correlation with the volcanic stratigraphic sequence. Some of these are likely associated with 
the pre-Bonanza Rawley volcanic complex, but others may be feeders for postcollapse lavas of the Bonanza cycle, upper units of the Conejos Formation, or even younger deposits

Rhyolite - Crystal-poor light-tan to light-gray dikes, locally flow laminated, that cut lavas of the Rawley complex, mainly along inner west wall of Bonanza caldera. Some may be related to the Rawley eruptions; others may be highly rheomorphic crack fills of rhyolitic Bonanza Tuff (unit Tfbr), although no relict fragmental textures were recognized in these dikes as mapped. Dike thickness, typically $2-5 \mathrm{~m}$

Dacite - Tan to gray dikes and larger intrusive bodies, typically phenocryst rich, containing $\mathrm{pl}>\mathrm{bi}>\mathrm{hbl}$, cpx. Several irregular dike-like bodies of light-colored dacite along the northwest caldera wall at the head of Kerber Creek (BZ) contain small altered sanidine phenocrysts and resemble intrusive Eagle Gulch Dacite (unit Ted) to the south; alternatively, these bodies may be associated with the older Sheep Mountain Dacite (unit Tmds) just to the north. Intrusive dacite above Mosquito Lake (BZ) contains megacrysts of altered K-feldspar as much as $5 \mathrm{~km}$ across; the $\mathrm{K}$-feldspar was too altered to date, but these intrusions may be associated with postcaldera megacrystic dacite (unit Tbdk) lavas that are preserved nearby to the northeast. Other dacite dikes in the cirque north of Antora Peak intrude thick dacitic Bonanza Tuff and are likely concurrent with postcollapse dacite lavas of the Bonanza cycle (unit Tbfd). Dike thickness, commonly $1-5 \mathrm{~m}$ $\mathrm{hbl}$ ). Most abundant along ridges adjacent to upper Greenback Gulch (WH), where may constitute offshoots from the texturally diverse postcaldera Turquoise Mine intrusion to the northeast. Some small unmapped areas of plagioclase andesite, embedded within finer-grained andesite of the Rawley complex (unit Tra), may also be intrusive; alternatively could be intermingled porphyritic facies within texturally heterogeneous lavas

Andesite - Intrusive andesite and fine-grained granodiorite. Finely porphyritic dark-gray dikes cut diverse rocks of the southern Bonanza caldera floor. Several small andesitic dikes crop out on the southern slopes of Hayden Peak (WH). A few compositionally similar dikes intrude Precambrian and Paleozoic rocks along the south caldera margin, north of Mine Gulch and near the mouth of Graveyard Gulch (GG). Such dikes likely are more abundant than mapped, especially in andesitic country rocks. Some dikes may be distal phases of the Turquoise Mine resurgent intrusion; others could be precaldera intrusions associated with growth of the Rawley complex. Dike thickness, mostly $<1-2 \mathrm{~m}$. An intrusion of texturally transitional andesite-granodiorite is exposed over an area about $500 \mathrm{~m}$ in diameter just west of O'Haver Lake (MO); it may form the core of a central volcano of the Conejos Formation, related to the andesite-dacite lava sequence it intrudes

Postcaldera lavas and volcaniclastic rocks - A thick sequence of compositionally diverse lavas and volumetrically minor associated volcaniclastic rocks, varying from andesite to high-silica rhyolite, accumulated within Bonanza caldera after subsidence and spread across proximal outflow Bonanza Tuff (photo 13). Diverse stratigraphic names, in places inconsistent with rock composition, have been applied to the postcaldera lavas. The lowermost andesitic lavas of this assemblage were named Squirrel Gulch latite and overlying silicic lavas Porphyry Peak rhyolite in the Bonanza mining district (Patton, 1916; Burbank, 1932). In its type area, the Brewer(y) Creek latite of Burbank (1932), mapped as the youngest mafic lava of the area, consists of andesitic debris in Quaternary moraine and landslide debris along the moat valley between the resurgent dome and western caldera wall. Farther north from Slaughterhouse to Mosquito Creeks, however, sanidine-bearing dacite mapped by Burbank as Brewer Creek latite overlies and banks against constructional highs of Porphyry Peak Rhyolite.

Beyond the caldera, dark lavas of andesite and mafic dacite that overlie outflow Bonanza Tuff north of Saguache Creek on southwest flanks of the Bonanza center (LMNE) were designated the andesite of Ford Creek by Bruns and others (1971). More recently, the entire package of postBonanza lavas of intermediate composition was informally termed "upper andesite" (Varga and Smith, 1984), but many of these rocks, especially those that spread beyond the caldera margins, are dacite rather than andesite.

Accordingly, an attempt has been made for this map to divide postcaldera lavas of the Bonanza cycle more consistently by composition and stratigraphic sequence. Most of this assemblage within Bonanza caldera is tilted conformably with the Bonanza Tuff and, thus, predates caldera resurgence. The lava sequence is less altered than the underlying Bonanza Tuff within the caldera, either because it postdates the alteration or because the alteration was confined to lower parts of the caldera fill sequence. Outside the caldera, without intervening Bonanza Tuff, some postcaldera andesites and dacites are difficult to distinguish from nearby lavas of similar compositions that predated the Bonanza caldera cycle. Regionally, these rocks are equivalent in age to younger rocks of the Conejos Formation farther south and west in the San Juan region (fig. 9) 

tuffaceous sandstone, banked against andesitic rocks (unit Tra) along the southern caldera wall west of Little Kerber Creek (GG). Interpreted to represent shallow-water deltaic and lake sediments, deposited locally in parts of the caldera moat not filled by rapidly deposited lavas. This interpretation is somewhat uncertain, because of lack of contact relations with Bonanza Tuff or postcaldera lavas. Absence of similar sedimentary rocks elsewhere in postcaldera fill suggests voluminous eruption of lavas after caldera collapse, at rates too rapid for any sizable aqueous deposits to accumulate. Preserved thickness, 0-20 m

Tbdh Hayden Peak Dacite - Areally restricted erosional remnants of distinctive massive gray lavas of silicic dacite (69.2-70.5\% $\mathrm{SiO}_{2}$ ), occupying upper slopes of Hayden Peak (photo 13.4) and extending along ridge to north (WH). Previously described as Hayden Peak latite by Patton (1916) and Burbank (1932). Exposed largely as talus on steep slopes, with only rare frost-wedged semi-outcrops. Contains sparse small phenocrysts $(\sim 10 \%, 1-2 \mathrm{~mm})$ of plagioclase and biotite in a felty trachytic matrix. The Colorado State and Saguache County geologic maps depict the rocks on Hayden Peak as intrusive (Tweto, 1979; Cappa and Wallace, 2007), but the fine grain size, flow foliation, and concordant basal contact indicate origin as thick lavas. Probably broadly correlative with other finely porphyritic dacite of the Bonanza cycle (unit Tbfs) but mapped separately because of distinctive textures, higher silica content, and uncertainties about relative age and stratigraphic position relative to other postcaldera lavas. Deposited against the lower intracaldera rhyolite of the Bonanza Tuff and underlying calderafloor rocks, seemingly along a deep paleovalley or possibly in an obscure fault-bounded keystone graben of the caldera resurgent dome. ${ }^{40} \mathrm{Ar} /{ }^{39} \mathrm{Ar}$ ages for two groundmass samples $(32.83 \pm 0.15 \mathrm{Ma}$ plateau, 32.76 $\pm 0.12 \mathrm{Ma}$ isochron; 32.64 $\pm 0.10 \mathrm{Ma}$ plateau, $32.58 \pm 0.11 \mathrm{Ma}$ isochron) are indistinguishable and only slightly younger than other postcaldera lavas. Another age of $34.08 \pm 0.13 \mathrm{Ma}$ (biotite plateau) is inconsistent with the stratigraphic position of the dacite, above rhyolitic Bonanza Tuff (unit Tbrl); similar problems with anomalously old biotite ages from volcanic rocks have been widely recognized (Hora and others, 2010). Thickness, as much as $250 \mathrm{~m}$, with top of the sequence eroded

Tbdk K-feldspar dacite - Thick massive lavas of gray porphyritic dacite lava (65.6-66.1\% $\left.\mathrm{SiO}_{2}\right)$, containing $15-25 \%$ phenocrysts ( $\mathrm{pl}>\mathrm{sn}$, bi, qtz), some with sanidine phenocrysts as much as $2 \mathrm{~cm}$ across $\left(\mathrm{Or}_{57.8} \mathrm{Ab}_{39.0} \mathrm{An}_{2.0} \mathrm{Cn}_{1.3}\right)$. Widely exposed along the northwest caldera margin (BZ) and to the north along Poncha Creek (MO). Welded dacitic tuff 5-10 m thick is present along the base of this unit, where well exposed above Porphyry Peak Rhyolite (unit Tbfr) along the Mears toll road trail $400 \mathrm{~m}$ east of hill 10,528' (BZ). Coarse slabby flow layering is developed locally, especially in lower parts of lavas. Attitudes on flow layering are somewhat variable, but map geometry of basal contacts indicates that the K-feldspar dacite along the caldera margin dips to the northwest as a result of resurgent doming within the caldera. In parts of some lavas (more distal?), sanidine is smaller and less abundant, and the K-feldspar dacite becomes similar in appearance to less coarsely porphyritic dacite lavas (unit Tbfd), which have been mapped separately. An area of altered K-feldspar dacite, along the north ridge of Porphyry Peak (BZ), has relatively coarse groundmass textures and may be a shallow vent intrusion or endogeneous part of a lava dome. Sanidine phenocrysts have complex zoning and resorption textures, with celsian compositions varying from $0.9 \mathrm{~mol} \%$ in cores to $1.8 \mathrm{~mol} \%$ along rims. Two ${ }^{40} \mathrm{Ar} /{ }^{39} \mathrm{Ar}$ ages (sn), $32.79 \pm 0.05$ and $32.76 \pm 0.05 \mathrm{Ma}$, are slightly younger than those from the underlying more finely porphyritic dacite (unit Tbfd; 33.05 $\pm 0.04 \mathrm{Ma}$ ) and Porphyry Peak Rhyolite (unit Tbfr; 33.06-33.05 Ma) along Silver Creek (MO). Maximum exposed thickness, $>150 \mathrm{~m}$

Dacite lavas - Widely scattered lavas of gray porphyritic dacite lava $\left(62.2-65.9 \% \mathrm{SiO}_{2}\right)$, containing $15-25 \%$ phenocrysts ( $\mathrm{pl}>>$ bi, cpx,$\pm \mathrm{sn}$ ). Slabby flow layering developed locally, especially in lower parts of lavas. Some dark crystal-rich lavas mapped with this unit, especially areas of slumped dacite between Slaughterhouse and Brewery Creeks (BZ), merge in phenocryst content and composition $\left(60.2 \% \mathrm{SiO}_{2}\right)$ with coarsely porphyritic plagioclase andesite (unit Tbap). This unit lacks sanidine phenocrysts in most areas, but local exposures of sanidine-bearing dacite provide important age constraints on duration of postcollapse magmatism at Bonanza.

A distinctive dacite lava $\left(62.3-65.6 \% \mathrm{SiO}_{2}\right)$ preserved as a deep paleovalley fill along Silver Creek (MO) contains sparse sanidine phenocrysts (mostly $<3 \mathrm{~mm}$ across), overlies Porphyry Peak Rhyolite, and may be more closely related to the adjacent K-feldspar dacite (unit Tbdk) than to sanidine-free dacite lava of post Bonanza age in other areas. Sanidine from this flow is complexly resorbed and strongly zoned, with cores $\left(\mathrm{Or}_{57} \mathrm{Ab}_{38} \mathrm{An}_{4.6} \mathrm{Cn}_{0.7}\right)$ and rims $\left(\mathrm{Or}_{61} \mathrm{Ab}_{33} \mathrm{An}_{1.9} \mathrm{Cn}_{3.8}\right)$; it has yielded a ${ }^{40} \mathrm{Ar} /{ }^{39} \mathrm{Ar}$ age of $33.05 \pm 0.04 \mathrm{Ma}$.

Another late dacite lava that contains sparse sanidine phenocrysts $\left(33.05 \pm 0.02 \mathrm{Ma}, 66.0 \% \mathrm{SiO}_{2}\right)$ is poorly exposed as surface rubble above Porphyry Peak Rhyolite (unit Tbfr) along ridges between 
Slaughterhouse and Kerber Creeks (BZ). Part of this dacite was mapped as Brewer(y) Creek latite by Burbank (1932), but the rocks he mapped as this unit in the type area of geographic Brewery Creek are Quaternary landslide and glacial till.

An exposure of sanidine dacite, high on the south flank of Baxter Mountain (southwest BZ), yielded an unexpectedly young ${ }^{40} \mathrm{Ar} /{ }^{39} \mathrm{Ar}$ age (sn) of $33.00 \pm 0.02 \mathrm{Ma}$; this lava appears to be a small erosional remnant of outflow postcaldera dacite, rather than interlayered with the adjacent Rawley lavas.

A poorly exposed small area of variably altered crystal-rich sanidine-bearing lava (20-25\% pl, sn, bi) appears to underlie the Porphyry Peak Rhyolite low on the south slope of Porphyry Peak at the head of Squirrel Gulch, in contrast to the sequence at other localities. This silicified-appearing rock $\left(72.3 \% \mathrm{SiO}_{2}\right)$, and similar light-colored porphyritic lava at a higher stratigraphic level on the northwest flank of Porphyry Peak, could alternatively have been mapped as crystal-rich phases of Porphyry Peak Rhyolite (unit Tbfr). Maximum preserved thickness, $>100 \mathrm{~m}$.

Additional dacite lavas that lack sanidine cap the outflow Bonanza Tuff south of the caldera, especially along the ridge crest between Findley and Dry Gulches (KM)

Finely porphyritic dacite lavas - Petrographically diverse light- to dark-gray lavas of dacitic composition $\left(64.2-66.7 \% \mathrm{SiO}_{2}\right.$ ), containing variable concentrations of phenocrysts (pl, bi, cpx, hbl) that are smaller or sparser than in more typical dacite lavas (unit Tbfd). No sanidine was identified. Mapped separately only along crest of ridge west of Findley Gulch (KM). Finely porphyritic dacite was difficult to distinguish from silicic andesite during field work, and some finely porphyritic dark lavas mapped as postcaldera andesite (unit Tba) have dacitic compositions. Maximum preserved thickness, $>50 \mathrm{~m}$ $\mathrm{SiO}_{2} ; 5-10 \%$ phenocrysts of sn, qtz>pl $>$ bi) along the northwest margin of Bonanza caldera (BZ), where originally described by Patton (1916) and later named by Burbank (1932). Several recent geologic maps have depicted the Porphyry Peak Rhyolite as intrusive (Tweto and others, 1976; Tweto, 1979; Varga and Smith, 1984) but, in agreement with the early work by Burbank and Patton, the rhyolite is interpreted here as a sequence of thick lavas. The rhyolite lava is locally well flow layered, but much is structureless; it widely breaks down into small slabs and chips of talus, and outcrops are rare (photo 13.3). In places, steeply-dipping flow layering defines vitrophyric ramp structures near tops of lavas, emplacement features that could have been misinterpreted as intrusive structures. In contrast to overlying dacite lavas, sanidine in the Porphyry Peak Rhyolite is relatively sodic and unzoned: $\mathrm{Or}_{52.1} \mathrm{Ab}_{45.5} \mathrm{An}_{2.1} \mathrm{Cn}_{0.22}$. For two samples from the type area, ${ }^{40} \mathrm{Ar} /{ }^{39} \mathrm{Ar}$ ages (sn) are $33.01 \pm 0.06$ and $33.05 \pm 0.09 \mathrm{Ma}$, marginally younger than the Bonanza Tuff and consistent with the stratigraphic sequence. In the few places where attitudes of flow layering are consistent over sizable areas, westward dips indicate emplacement of the rhyolite prior to resurgent doming of the caldera.

A small area of silicified red-brown porphyritic rhyolite $\left(76.7 \% \mathrm{SiO}_{2} ; 1 \%\right.$ small phenocrysts of qtz, argillized plagioclase and K-feldspar, and sericitic mica) high on the steep southeast ridge of Sheep Mountain (BZ) appears related to a dike-like small body of intrusive rhyolite of similar appearance downslope to south; the entire mass may be a shallow intrusion. Argillized sanidine from the Sheep Mountain locality yielded a poorly constrained isochron ${ }^{40} \mathrm{Ar} /{ }^{39} \mathrm{Ar}$ age of $32.04 \pm 0.34$ $\mathrm{Ma}$, with a complex spectrum. Tentatively interpreted here as an altered outlier of Porphyry Peak Rhyolite on the northwest Bonanza caldera wall; alternatively could record a late eruption related to Marshall caldera.

Beyond Bonanza caldera, a paleovalley-filling lava along the ridge between Silver and Poncha Creeks (MO) is similar to the intracaldera rhyolite in composition $\left(74.0-74.8 \% \mathrm{SiO}_{2}\right.$, sanidine composition $\left.\mathrm{Or}_{52.4} \mathrm{Ab}_{44.8} \mathrm{An}_{2.2} \mathrm{Cn}_{0.6}\right)$ and ${ }^{40} \mathrm{Ar} /{ }^{39} \mathrm{Ar}$ age (33.05 $\left.\pm 0.07,33.06 \pm 0.09 \mathrm{Ma}\right)$.

In addition, light-gray tuff preserved in two small areas records late-stage silicic volcanism closely associated with the Bonanza cycle. Talus of partly welded rhyolite tuff $\left(76.9 \% \mathrm{SiO}_{2} ; 5-10 \%\right.$ small phenocrysts of sn, pl, bi), at 3,475 m (11,400 ft) elevation along the northeast ridge of Flagstaff Mountain (BZ), yielded a high-quality ${ }^{40} \mathrm{Ar} /{ }^{39} \mathrm{Ar}$ sanidine age of $32.51 \pm 0.02 \mathrm{Ma}$. At time of sampling, this poorly exposed tuff was interpreted as likely interlayered with the pre-Bonanza lava sequence, but the age indicates that this unit must be a younger tuff plastered unconformably against the west wall of Bonanza caldera.

Weakly indurated crystal-poor rhyolite tuff, preserved only as a small area of float in a meadow on the flat top of Sargents Mesa $1.1 \mathrm{~km}$ west of the Bonanza map area (lat $38^{\circ} 17.07^{\prime} \mathrm{N}$., long $106^{\circ} 23.25^{\prime}$ W.), was sampled as a candidate for basal outflow Bonanza Tuff. Two samples yielded ${ }^{40} \mathrm{Ar} /{ }^{39} \mathrm{Ar}$ sanidine ages $(32.72 \pm 0.02,32.83 \pm 0.03 \mathrm{Ma})$ that preclude any preservation of Bonanza Tuff on Sargents Mesa. This tuff seems likely to record small-volume explosive eruptions associated with late dacitic or rhyolitic lavas of the Bonanza cycle (perhaps concurrent with unit Tbdk). 
Tblr

Tbab

Tbam

Tba

Tbap

No eruptive vents were identified for the Porphyry Peak Rhyolite, but mineral and chemical compositions are similar to the aplitic granite of Spring Creek (unit Tas) on the east flank of the resurgent dome, which may be a broadly equivalent intrusive phase. These relations suggest that late eruption of silicic rhyolite may once have been much more widespread in the caldera area than recorded by present-day exposures. Maximum preserved thickness, $>300 \mathrm{~m}$

Rhyolite of Laughlin Gulch-Isolated small erosional remnants of light-gray crystal-poor flow-laminated rhyolite and flow breccia $(<5 \% \mathrm{pl}$, qtz $>$ bi) between Bonanza Tuff and postcaldera andesite lavas mapped as part of the Bonanza caldera cycle, along lower Laughlin Gulch (LG). Alternatively, this flow could record a north-flank eruption from the Tracy volcano, which continued to be active concurrently with the Bonanza cycle. South of Laughlin Gulch, volcaniclastic debris, containing clasts of this rhyolite, interfingers with lavas of the Tracy volcano. Thickness, 0-30 m

Andesitic rocks - Diverse dark-gray lavas and volcaniclastic rocks that overlie Bonanza Tuff within and proximal to Bonanza caldera (photo 13.1). These lavas are notably less altered or propylitically metamorphosed than otherwise compositionally similar precaldera andesites (unit Tra), reflecting their younger ages and structurally higher positions

Upper dark andesite-Distinctive unit of massive dark-gray to black vesicular lavas and proximal breccia (photo 13.2), exposed mainly west of Middle Creek (CH). Informally called the "malpais andesite" because of its fresh appearance, common frothy vesicular textures, and exposure in large boulders that make for difficult walking, in contrast to underlying andesite units. These lavas are preserved in a structural low west of a structural hinge line along Middle Creek that may reflect the buried western side of the 34-Ma Marshall caldera. They overlie Bonanza Tuff at north and south margins of their present outcrop area, bank out against oxidized tan lavas of roughly similar composition on Sargents Mesa, and cover diverse pre-Bonanza lavas to the east and south. Attempts to date groundmass from two samples yielded inconsistent step-heating ages $(33.58,31.76 \mathrm{Ma})$, characterized by recoil spectra. As presently mapped, the upper dark andesite may constitute vesicular proximal equivalents of dense less-vesicular andesite lavas of the Bonanza cycle (unit Tba) that are preserved as discontinuous ridge caps farther to the southeast (LMNE)

Breccia cone and spatter - Crudely bedded chaotic breccia and spatter of dark andesite (photo 13.2), forming large cliff outcrops west of Middle Creek $(\mathrm{CH})$ that appear to be the east flank of an eruptive cone. Interlayered with lesser volumes of lava with irregular shapes. Maximum thickness, $>300 \mathrm{~m}$

Andesite flows - Nearly aphyric dark-gray to black vesicular a'a lavas $\left(56.7-58.7 \% \mathrm{SiO}_{2}\right)$ with basal and upper breccias, making gently dipping layers adjacent to the breccia-cone deposits (unit Tbab) west of Middle Creek (LMNE, CH). Scoriaceous zones between lavas are locally oxidized to bright red-brown colors. Maximum thickness, $>400 \mathrm{~m}$

Sparsely porphyritic andesite lavas - Widespread lavas of dark-gray to brown fine-grained andesite (56.0-59.8\% $\mathrm{SiO}_{2}$ ), some containing sparse small phenocrysts ( $\mathrm{pl}$, hbl, cpx). Unit also includes variable proportions of phenocryst-poor dark dacite $\left(65.2-66.1 \% \mathrm{SiO}_{2}\right)$ that is difficult to distinguish from andesite without chemical analyses. Previously described as the andesite of Ford Creek by Bruns and others (1971). Widely caps mesas southwest of Bonanza caldera (eastern LMNE, southwest CH). In places, directly above outflow Bonanza Tuff; along Middle Creek where Bonanza Tuff is absent, these lavas overlie finely plagioclase-phyric precaldera andesite (unit Tra) of contrasting appearance. Mostly absent from the preserved late lava sequence within the caldera. In some areas of rugged paleotopography where Bonanza Tuff is absent, contacts between pre- and post-Bonanza andesite lavas (units Tra, Tba) that are petrographically similar are difficult to locate with confidence: for example, ridges southwest of survey point "Stump" (BZ, CH) and slopes west of Baxter Creek (LMNE). Some lavas on slopes of Houghland Hill and capping the ridge west of Findley Gulch may have erupted from sources farther south; they may be correlative with andesite and finely porphyritic dacite (units Tyau, Tydu) mapped as part of the Tracy volcano south of Laughlin Gulch. Maximum thickness, $>200 \mathrm{~m}$

Plagioclase-rich andesite lavas - Coarsely porphyritic silicic andesite $\left(\sim 58-62 \% \mathrm{SiO}_{2} ; \mathrm{pl}>>\mathrm{cpx}\right)$, containing blocky plagioclase crystals (to $5 \mathrm{~mm}$ ) and sparse biotite in dark-gray groundmass. Transitional in composition to overlying dacite (unit Tbfd). Forms relatively thick individual flows (to $20 \mathrm{~m}$ ) on west flank of resurgent dome within caldera (BZ). A tilted flow east of Slaughterhouse Creek (BZ) directly overlies Squirrel Gulch Andesite (unit Tbas) on the west flank of the resurgent dome. Similarly distinctive plagioclase-phyric andesite is common in lava sequences elsewhere in the region, both predating Bonanza caldera (units Tyap, Trap, Tcap) and associated with younger ignimbrites and calderas farther southwest in the San Juan region (for example, Sheep Mountain Andesite associated with Masonic Park Tuff, Huerto Andesite within the La Garita caldera: Lipman, 2000, 2006). Maximum thickness, $50 \mathrm{~m}$ 
Squirrel Gulch andesite - Distinctive biotite-bearing dark-gray porphyritic andesite lavas (58.8-59.8\% $\mathrm{SiO}_{2} ; 10-20 \% \mathrm{pl}>\mathrm{bi}, \mathrm{hbl}$ ), which directly overlie intracaldera Bonanza Tuff on west flank of resurgent dome (BZ). Originally named and described by Burbank (1932). Distinguished from other postcaldera andesites by presence of hornblende and abundant biotite, despite dark groundmass color and relatively mafic bulk composition. Maximum thickness, $>200 \mathrm{~m}$

Tbav

Volcaniclastic rocks-Several unrelated local deposits that are tentatively related to the Bonanza cycle, based on lithology and stratigraphic position. Conglomerates containing cobbles of flow-layered porphyritic rhyolite are poorly exposed in proximity to remnants of outflow Bonanza Tuff along the Continental Divide at the head of Duncan Creek (CH); one cobble has a ${ }^{40} \mathrm{Ar} /{ }^{39} \mathrm{Ar}$ sanidine age of $32.97 \pm 0.01 \mathrm{Ma}$. A rhyolitic cobble, from conglomeratic float that appears to be raveling out from beneath dacite lavas in upper Middle Creek, yield a similar age (32.99 $\pm 0.01 \mathrm{Ma})$. The phenocrysts in the cobbles and their ages suggest derivation from flows of Porphyry Peak Rhyolite (unit Tbfr), and locations of the conglomerates document major erosion concurrent with late stages of the Bonanza caldera cycle.

South of the caldera, andesitic conglomerates and finer sediments lie between post-Bonanza andesites and Saguache Creek Tuff in Bear Creek and adjacent drainages (LMNE). Coarsely bedded sedimentary rocks, which interfinger between the rhyolite of Laughlin Gulch (unit Tblr) and overlying andesite (LG, LMNE), include poorly sorted sandstone and coarser breccia containing clasts of andesite, along with light-gray crystal-poor rhyolite probably derived from the underlying rhyolite of Laughlin Gulch. Maximum thickness, $50 \mathrm{~m}$.

Within Bonanza caldera, weakly indurated conglomerates and interlayered sandy beds, containing mainly andesitic clasts, form bouldery slopes, as poorly exposed in Studhorse Creek and adjacent drainages (GG). These rocks lap out against more altered and indurated precaldera andesite (unit Tra) along the south caldera margin and are overlain by dissected Quaternary gravels (unit Qfo). They are tentatively interpreted as Oligocene caldera fill eroded from the adjacent caldera wall, although lack of outcrops and poor stratigraphic control would permit interpretation as younger Tertiary alluvial deposits in a paleo-Kerber valley. Maximum thickness, $\sim 100 \mathrm{~m}$

Bonanza Tuff-Voluminous ignimbrite sheet displaying complexly gradational welding and compositional variations (photo 9), which differ inside versus outside the source caldera (fig. 13).

West of Bonanza caldera, the outflow ignimbrite sheet is dominantly crystal-rich dacite in composition (photo 9.2) but changes from densely welded lower crystal-poor rhyolite (unit Tbrl, minor, local) to widespread dacite (unit Tbd), upward into less welded rhyolite (unit Tbrl) and, locally, to an upper welded dacite (unit Tbdu) in some proximal sections (fig. 13). Especially complex compositional and welding zones along the margin of a paleovalley are well exposed on east slopes of the ridge west of Findley Gulch (KM; photo 9.1), which has been used as a reference section for the Bonanza Tuff and designated the Findley Ridge section in several previous studies (Bruns and others, 1971; Varga and Smith, 1984; McIntosh and Chapin, 2004). In contrast, outflow Bonanza Tuff beyond the map area to the northeast, which until recently had been considered a separate ignimbrite, the Gribbles Park Tuff (Epis and Chapin, 1974; McIntosh and Chapin, 2004), consists dominantly of rhyolite (unit Tbr) but contains a thin central zone of dacite (unit Tbd), at least in sections such as Two Creek (Jack Hall Mountain quadrangle; photo 9.3; table 5).

The thick intracaldera Bonanza Tuff contains even more complex compositional variations (photo 9.4). Where a complete 2.5 -km-thick section is exposed on the west flank of the resurgent dome, rhyolite and dacite compositional zones alternate 11 times; dacite is volumetrically dominant, but the eruptive sequence began and ended with rhyolite (fig. 14A). The dacite is typically densely welded; much of the rhyolite is only partly welded (unit Tbrn), but some deep zones are densely welded and fluidal (unit Tbrl), even locally rheomorphic (unit Tbrr). Caldera-wall landslide breccias interfinger with the intracaldera tuff, and some lower parts of the rhyolite tuff contain abundant lithic fragments (unit Tbrb).

Because the outflow sheet was deposited on irregular paleotopography and stratigraphic continuity is lacking between many areas of exposure, a large number of isotopic age determinations have been used to test stratigraphic correlations. Weighted mean ${ }^{40} \mathrm{Ar} /{ }^{39} \mathrm{Ar}$ age (sn) for 13 samples of outflow Bonanza Tuff from throughout its regional extent is $33.12 \pm 0.03$ (table 2)

Dacite - Mainly densely welded dark-gray to brown crystal-rich welded dacite $\left(61-68 \% \mathrm{SiO}_{2} ; 25-35 \%\right.$ $\mathrm{pl}>>\mathrm{bi}$, sn, cpx, qtz). Outflow deposits are mainly preserved as discontinuous erosional remnants in paleovalley fills. Average sanidine composition: $\mathrm{Or}_{65} \mathrm{Ab}_{31} \mathrm{An}_{2.3} \mathrm{Cn}_{2.2}$ with complex $\mathrm{Cn}$ zoning $\left(\mathrm{Cn}_{0.5->6}\right)$. Thickness in outflow ignimbrite, $0-150 \mathrm{~m}$; dominant component of ponded intracaldera ignimbrite, with multiple dacite zones. Divided into several outflow and intracaldera subunits 
Upper outflow dacite - Local welded unit, only in proximal areas on west side of map area. Especially well exposed on ridge west of Findley Gulch (KM; photo 9.1) and north side of lower Poison Gulch (LMNE). Despite relatively low $\mathrm{SiO}_{2}(61.8 \%)$, contains abundant sanidine that is highly variable in composition and indicative of mixing (during eruption?) of rhyolitic and more mafic magmas. Maximum thickness, $25 \mathrm{~m}$

Tbd

Main dacite - Dominant component of the outflow ignimbrite in map area and multiple compositional zones that alternate with rhyolite within caldera.

Outflow-Main welded unit on west side of map area; overlain by upper rhyolite (unit Tbru) in proximal areas along Saguache Creek and tributaries (photo 9.2B), but forms entire section of Bonanza Tuff at more distant western sites. Multiple welding zones are present along some proximal paleovalleys such as the ridge west of Findley Gulch (photo 9.1). On this ridge and in upper Dry Gulch to the northwest (KM; photo 13.1A), lower parts of the dacite are densely welded to fluidal, have little-broken tabular plagioclase phenocrysts, lack sanidine, have few lithic fragments, and can be difficult to distinguish in outcrop from dacite lava where the zonation to less welded tuff is covered. In places such as southeast of Poison Gulch, good exposures show that the upper partly welded zone of the main dacite becomes less crystal-rich and rhyolitic in composition (sample 02L-22A, table 5), well below the maximum cooling/welding break that marks the transition to the overlying cliff of upper rhyolite.

East of caldera, beyond map area, silicic dacite forms a central zone about $15 \mathrm{~m}$ thick $(68.8 \%$ $\mathrm{SiO}_{2}$, sample 08L-33E), within the dominant rhyolite in a much-studied 180-m-thick section of outflow Bonanza (Gribbles Park) Tuff at Two Creek (photo 9.3, Jack Hall Mountain quadrangle; Epis and Chapin, 1974; McIntosh and Chapin, 2004). A central zone of more crystal-rich welded tuff of probable dacite composition is also present within the eastern outflow Bonanza (Gribbles Park) Tuff where examined in East Gulch (Black Mountain quadrangle; Epis and others, 1979). Maximum thickness in map area, $150 \mathrm{~m}$ on ridge west of Findley Gulch (KM).

Intracaldera-Dominant densely welded component of caldera-filling ignimbrite (photo 9.4), forming rugged cliffs above valleys cutting west flank of resurgent dome (BZ). In places, large flattened pumices are elongate down dip (photo 9.4C), defining a lineation that formed by flowage of still hot and viscous welded tuff, perhaps during resurgent uplift of the caldera interior. As many as six separate zones of dacite are present on tilted west flank of resurgent dome (fig. 14A; photo 15.1), separated by intervening rhyolite and megabreccia (BZ). Widely hydrothermally altered or propylitically metamorphosed within caldera, but unaltered phenocrysts preserved in places. Locally, so propylitically metamorphosed and otherwise altered that tuffaceous and flattened-pumice texture completely obliterated, and identification depends largely on ubiquitous intracaldera presence of small angular fragments of andesite. ${ }^{40} \mathrm{Ar} /{ }^{39} \mathrm{Ar}$ ages (sn) from three intracaldera dacites near Squirrel Gulch (BZ) are 33.06-33.35 Ma (McIntosh and Chapin 2004, adjusted standard), consistent with age determinations from outflow Bonanza Tuff. Cumulative intracaldera thickness, as much as 1,700 m

Tbdn Nonwelded dacite - Thin zones of wealkly indurated tuff, locally sufficiently thick to map both within the caldera and as outflow deposits

Outflow-Nonwelded tan dacite in an obscure gully exposure south of upper Middle Creek (CH), which has yielded a ${ }^{40} \mathrm{Ar} /{ }^{39} \mathrm{Ar}$ age (sn) of $33.10 \pm 0.07 \mathrm{Ma}$, and found as poorly exposed zones between more welded dacite that are mostly too thin to map separately.

Intracaldera - Nonwelded to partly welded tan dacite forming poorly exposed thin zones between more welded zones and at the base of dacite sections. Mapped separately only in areas of exceptionally good exposure, such as west slope of Raspberry Peak (BZ) and low along Clover Creek (WH-PP). In hydrothermally altered areas, distinction can be difficult between this unit and weakly welded rhyolite (unit Tbrn). Maximum thickness, about $25 \mathrm{~m}$

Intracaldera dacite fracture fill-Rare steeply dipping welded dike-like crack fills in caldera-floor or megabreccia host rocks. One dike is well exposed centrally along north edge of Graveyard Gulch quadrangle; others are marked by local float of welded dacite within large areas of andesite lavas along caldera floor. Uncertain origin as dilatant fracture-filling dikes fed from above; alternatively, pyroclastic feeder vents. Fracture-fill origin favored by areal distribution: confined to locations within or closely adjacent to megabreccia low in the intracaldera section. Some small areas of dacitic megabreccia matrix that are too poorly exposed to determine fracture orientation are shown by brown asterisk symbols; such occurrences are probably much more common than have been mapped. Gradational with less-welded tuffaceous matrix in megabreccia (Tbmu). Thickness, less than a few meters

Rhyolite - Crystal-poor rhyolite (mostly $72-74 \% \mathrm{SiO}_{2} ; 5-10 \% \mathrm{sn}>>$ pl $>>$ bi, hbl). Red-brown where densely welded; light gray to tan where weakly welded. Multiple zones of rhyolite that interfinger with dacite in thick ignimbrite ponded within Bonanza caldera are typically only partly 
welded and especially susceptible to supergene alteration. Compared to other crystal-poor biotite-bearing rhyolite tuffs in the map area (units Tws, Tcr), rhyolitic Bonanza Tuff has a higher ratio of sanidine:plagioclase phenocrysts, contains sparse small hornblende in addition to biotite and accessory titanite, and has lower Or and $\mathrm{Cn}$ in sanidine. Average sanidine composition: $\mathrm{Or}_{53} \mathrm{Ab}_{45} \mathrm{An}_{1.9} \mathrm{Cn}_{0.03}$. Divided into several outflow and intracaldera subunits:

Upper rhyolite - Late-erupted thin deposit, both within caldera and in proximal outflow ignimbrite.

Outflow - Proximal unit of limited extent above main dacite, on southwest side of Bonanza caldera. Particularly well developed along the Saguache Valley (photo 13.1A), especially on northeast slopes of Houghland Hill and adjacent ridges between lower Findley Gulch and Ford Creek (KM, LMNE), where the dacite grades in crystal content and bulk composition upward to rhyolite along a zone of decreased welding but with no evidence for any significant depositional or time gap. Some prior brief descriptions (Bruns and others, 1971; Varga and Smith, 1984; McIntosh and Chapin, 2004) had left uncertain whether the upper rhyolite was a separate overlying ignimbrite. The recommendation by McIntosh and Chapin (2004, p. 230) that "the name Bonanza Tuff be restricted to the lower crystal-rich dacitic unit, and that Gribbles Park Tuff be used for the upper crystal-poor rhyolitic unit" in the Saguache Valley carries the implication that two separate ignimbrite sheets were present. In contrast, the relations summarized above demonstrate that main dacite and upper rhyolite are compositional and welding zones within a single ignimbrite sheet, which contains at least four compositional-welding zones in the outflow sheet, and as many as eleven within the source caldera. Additionally, the bulk of the eastern unit previously described as Gribbles Park Tuff appears correlative with the lower rhyolite, rather than the upper unit.

Intracaldera - Weakly welded yellow-tan to white crystal-poor tuff at top of tilted intracaldera section on west flank of resurgent dome (BZ). Widely bleached, oxidized, and otherwise altered Main intracaldera rhyolite - Multiple zones of variably welded crystal-poor rhyolite tuff (photo 9.5), alternating with intracaldera dacite (unit Tbr) and lenses of megabreccia within caldera. Especially well preserved on west flank of resurgent dome (BZ), where as many as five zones have been recognized. Most are weakly welded and variably altered, with appearance essentially the same as the upper intracaldera rhyolite (unit Tbru). Multiple zones of rhyolite, which interfinger gradationally with dacite tuff within the caldera, eliminate the rationale for many faults shown on previous maps of the Bonanza mining district (Burbank, 1932). Some highly altered areas mapped as intracaldera rhyolite may alternatively be weakly welded dacite (unit Tbd) with total-crystal and biotite content obscured by alteration. Individual zones are as thick as $100 \mathrm{~m}$; composite thickness, as much $400 \mathrm{~m}$ on west flank of resurgent dome Lower rhyolite - Volumetrically minor proximal outflow unit within map area, but main welded unit in widespread Bonanza Tuff to the east of the Rio Grande rift, where previously described as Gribbles Park Tuff (Epis and Chapin, 1974; McIntosh and Chapin, 2004). Thick lower part of caldera-fill rhyolite probably correlates with volumetrically dominant rhyolite in widespread outflow rhyolitic Bonanza Tuff to east.

Outflow - Welded tan crystal-poor rhyolite tuff overlies older andesite in a few places on west and south flanks of Bonanza caldera. On southeast slopes of Houghland Hill north of Laughlin Gulch (LG), partly welded rhyolite as much as $50 \mathrm{~m}$ thick on lower slopes grades upward into densely welded dacite, which in turn grades into upper rhyolite (unit Tbru). Similar relations between welded rhyolite and overlying dacite are preserved along ridges west of Phantom Creek, north of upper Indian Creek, and in Antora Meadows just west of the Bonanza caldera rim (BZ). Another small isolated remnant of thick densely welded lower Bonanza rhyolite is documented by an age determination and compositional data in Long Branch (SM), a few kilometers to the west of the Bonanza map area (Lipman, 2012).

The lower outflow rhyolite and its intracaldera equivalent are here interpreted to be proximal equivalents to the main lower rhyolite of the widespread outflow ignimbrite to the east of the Rio Grande rift, previously named Gribbles Park Tuff and interpreted to correlate with the upper outflow rhyolite (unit Tbru) of the Bonanza-Saguache area (Bruns and others, 1971; Varga and Smith, 1984; McIntosh and Chapin, 2004). At least locally (Two Creek section: lat $38^{\circ} 36.5^{\prime}$ N., long $105^{\circ} 46.8^{\prime}$ W.), the eastern outflow ignimbrite also contains a central dacite and weakly welded upper rhyolite as well (photo 9.3; table 1, 08L-33E, 09L-5B), which plausibly are equivalent to the proximal central dacite and upper rhyolite of the Bonanza Tuff (units Tbd, Tbru) as subdivided in the map area. Exposed thickness of the lower rhyolite in map area, as much as $50 \mathrm{~m}$ where locally present south and west of the caldera; as much as $125 \mathrm{~m}$ thick in outflow to the northeast.

Intracaldera - Welded tan crystal-poor rhyolite tuff directly overlies caldera-flow andesite locally on both flanks of resurgent dome. This part of caldera-filling ignimbrite is particularly well exposed on the east side of the resurgent crest along the ridge between forks of Cottonwood Creek and slopes to the south (WH). The crystal-poor lower rhyolite on the east side is massive, commonly without readily 
visible fiamme, and can resemble silicified andesite where lithics are absent. In places, it has a flow lamination similar to that in rhyolitic lava. On the west side, the lower rhyolite is especially thick along the ridge between Elkhorn and Copper Creeks (WH) and north of Rawley Gulch (BZ). Some welded tuff mapped as this unit on slopes of Hayden Peak and along the ridge to the north may include pyroclastic facies of older rhyolitic flows (units Trfr, Trt) that constitute part of the caldera floor. Attempts to test correlations by geochemistry and geochronology have been ambiguous, because of obscuring effects of widespread supergene alteration. Maximum thickness, about $150 \mathrm{~m}$

Brecciated rhyolite - Variably indurated light-gray lithic-rich crystal-poor rhyolite tuff, directly overlying caldera-floor andesite along ridge crest south of Elkhorn Peak (WH). Lithic fragments of andesite and densely welded tuff, and flow-laminated rhyolite, commonly 5-20 cm across, are typical. Clasts are too silicified and otherwise altered for age determination or reliable rock chemistry. Tentatively interpreted as fragments of early-erupted Bonanza rhyolite (units Tbrl, Tbrr), which were brecciated during early caldera subsidence and incorporated in matrix of later-erupted tuff. Alternatively, some of deposit may be caldera landslide breccia, containing abundant small clasts of older rhyolite lava (unit Trfr) in a tuffaceous rhyolite matrix. Maximum thickness, about $150 \mathrm{~m}$

Tbrr

Tbrn

Tfbr

Tbmu
Rheomorphic rhyolite - Thin zones of extreme welding and fluidal deformation within the lower rhyolite (photos 9.5, 10.3), where pumice flattening ratios approach 100:1 or more, become lineate and locally flow folded. Well developed on slopes between Rawley and Sosthenes Gulches, including hill 11,178' (BZ). Similar rheomorphic rhyolite on the south slope of Windy Point (BZ; photos $9.5 A, B)$ is probably banked against upper slopes of the west caldera wall. Distinction between rheomorphic lower rhyolite versus underlying true lavas of precaldera crystal-poor rhyolite (unit Trfr) remains confusing and uncertain in some areas of poor exposure, especially on flanks of Flagstaff Mountain (BZ). Maximum thickness, about $50 \mathrm{~m}$

Nonwelded rhyolite - White weakly indurated crystal-poor tuff, at base of tuff section where banked high on west caldera wall south of Antora Meadows (BZ), grades laterally and upward into more welded lower rhyolite (unit Tbrl). Unit is probably widespread at base of intracaldera tuff accumulation but too thin or poorly exposed to map reliably

Intracaldera rhyolite fracture fill-Steeply-dipping lenticular dike-like fracture fills of crystalpoor rhyolite tuff (typically $1-5 \% \mathrm{pl}, \mathrm{sn}>>\mathrm{bi}$ ), with strongly welded to fluidally drawn-out pumice lenses that dip steeply to vertically, within caldera-floor or megabreccia host rocks (photo 12). In places, more irregular larger lenses that have variable foliation trends merge with rhyolitic Bonanza Tuff (unit Tbr) and are sufficient size to map. Some mapped bodies that are fluidal throughout have fragmental character documented by angular lithic fragments of andesite. Others are distinguished from more regional rhyolite dikes (unit Tir) only by proximity to similarly oriented fragmental fracture fills with obvious fragmental texture. Most bodies are traceable along strike for only a few tens of meters on ridge crests, but some are likely continuous for $>100 \mathrm{~m}$ across valleys. Several bodies are well exposed as resistant ribs along north side of Kerber Creek (photo 12.1); others are marked by local float of welded rhyolite within areas of caldera-floor andesite lavas and overlying megabreccia (unit Tbma). Uncertain origin as dilatant fracture-fills fed from above; alternatively, pyroclastic feeder vents. Fracture-fill origin is supported by areal distribution: confined to within or closely adjacent to megabreccia low in the intracaldera section. Tendency to be parallel to the concealed ring fault along Kerber Creek (photo 12.1A) indicates close relation to caldera-collapse structures. Small areas of similar-appearing densely welded to fluidal rhyolite, which is sparsely present as locally concentrated float elsewhere within mapped areas of intracaldera megabreccia, is depicted with a red asterisk symbol; such occurrences likely are much more common than have been mapped. Gradational with less-welded tuffaceous matrix in megabreccia (Tbmu). Chemical data for crack-fill rhyolite that appeared relatively unaltered megascopically demonstrate extreme alkali exchange, to $8.67 \% \mathrm{~K}_{2} \mathrm{O}$ and only $0.24 \% \mathrm{Na}_{2} \mathrm{O}$ (table 5). Thickness, less than a few meters in most exposures

Intracaldera landslide breccia - Lenses and irregular masses of brecciated precaldera rocks, inferred to have been deposited by landslides from walls oversteepened during caldera collapse. Underlie and interlayered with intracaldera Bonanza Tuff (photo 10). Tuffaceous matrix to breccia blocks is best exposed in road cuts and other man-made exposures (photos $10.1 B, C$ ); for example, along the switchback road up to the ridge crest northwest of lower Rawley Gulch (BZ), where outcrops of at least ten andesite blocks, one about $15 \mathrm{~m}$ across, are surrounded by matrix of weakly welded tuff. Tuffaceous matrix is much less indurated than blocks, thus rarely exposed in natural outcrop. Interior parts of many breccia masses lack externally derived tuff matrix

Mixed clast or undivided megabreccia-Mixed blocks of andesite, dacite, and sparse Precambrian rocks, especially well exposed along ridge crest between Alder and Clover Creeks (WH) 
Andesite- and dacite-clast megabreccia-Dominant megabreccia lithology. Blocks of varied size, commonly 1-10 m, which locally form bold outcrops within areas of tuffaceous matrix that is poorly exposed as float on adjacent slopes. Matrix is best displayed where indurated by alteration and in man-made road and mine-exploration exposures such as along the lower Rawley Gulch road (BZ). Large areas of similar megabreccia underlie small patches of intracaldera Bonanza Tuff along the north slope of Kerber Creek between Sawmill and Drill Hole Gulches (GG) and also are present on steeply vegetated slopes to the south. In these areas, most outcrops are shattered andesite that lack stratigraphic coherence; fragments of lithic tuff are present as talus float, but exposures of tuffaceous matrix to megablocks are largely lacking. These rocks appear gradational into more massive coherent andesite, and some may constitute brecciated caldera floor rather than far-traveled landslide deposits. Similar interpretive difficulties in distinguishing between megabreccia and floor andesite characterize much of this unit where mapped along the slopes adjacent to Clover Creek (WH). In parts of this area, breccia matrix of pulverized andesite and dacite is difficult to distinguish from matrix of strongly propylitized dacitic Bonanza Tuff, and without exceptional exposures, contacts between in-place caldera floor and megabreccia dominated by andesitic clasts are difficult to locate with any precision

Tbmp Plagioclase-andesite-clast megabreccia-Scattered small areas of plagioclase andesite, floating within dacitic intracaldera Bonanza Tuff, mainly along the ridge north of Alder Creek and slopes east of upper Squirrel Gulch

Tbmc Proterozoic-clast megabreccia-Lenses of mixed Proterozoic rocks, mostly exposed only as blocky float, within dacitic intracaldera Bonanza Tuff in upper Squirrel Gulch, across the divide east of Porphyry Peak (BZ), and east of Sawmill Gulch (GG).

Especially problematic to interpret are distinctive shattered rocks derived from Proterozoic granitic rocks (p€g), which are well exposed in small areas along both sides of Kerber Creek near junction with Little Kerber Creek (GG), adjacent to basal deposits of Tertiary volcanic rocks. Blocks up to several meters across are juxtaposed, many with only minor matrix of pulverized granite (photo 16). Alternative interpretations might include (1) thrust-fault breccias, (2) late-Paleozoic talus deposits, (3) caldera-ring-fault breccias, and (4) caldera-collapse landslide deposits - considered most likely, as discussed in earlier section "An additional complexity"

\section{VOLCANIC ROCKS PREDATING BONANZA CALDERA}

$$
\text { Conejos Formation, Middle Units }
$$

Much of the intermediate-composition lava and breccia assemblage in the Bonanza region is older than the widespread Conejos rocks to the south and west that appear to have erupted largely in the interval 33-30 Ma (fig. 9). Accordingly, rocks that are overlain by the 33.12-Ma Bonanza Tuff and underlain by the 33.9-Ma Thorn Ranch Tuff have been mapped as middle units of the Conejos Formation. Lavas that form a constructional high in the vicinity of Bonanza caldera have long been designated the Rawley Andesite (Burbank, 1932; Varga and Smith, 1984), but compositionally similar pre-Bonanza lavas erupted from other large stratovolcanoes within the map area. Remnants of several large volcanoes of middle Conejos age are delineated on the geologic map and their lavas assigned separate unit designations: Tracy (31.6- 33.5? Ma), Sargents Mesa ( 33.2? Ma), Rawley (33.3-33.8 Ma), and compositionally diverse fill of Marshall caldera ( 33.6 - 33.9 Ma).

Because lava lithologies in these volcanoes are largely similar, mapped boundaries of their distal flanks are poorly constrained and in places located somewhat arbitrarily. In addition, the separately mapped lava fill of Marshall caldera is at least in part equivalent to older parts of the Rawley volcanic complex, and the postcollapse lava fill of Bonanza caldera is contemporaneous with upper units of the Tracy volcano. The exposed thickness of Conejos rocks is more than $800 \mathrm{~m}$ along the flanks of Saguache Peak (GG), $750 \mathrm{~m}$ at Tracy Mountain (LG), and $600 \mathrm{~m}$ at Sargents Mesa $(\mathrm{CH})$; thicknesses as much as $2.3 \mathrm{~km}$ have been penetrated by petroleum exploration drilling southeast of the map area (Gries, 1985; Brister and Gries, 1994).

$$
\text { Tracy Volcano }(<32.5 ?-33.5 \mathrm{Ma})
$$

Tracy is a deeply eroded central volcano (photo 6), containing compositionally diverse lavas on its outward-dipping flanks, a core area of thick andesite lavas that appears to have ponded within a summit caldera about $3 \times 4 \mathrm{~km}$ across, and an axial granodiorite intrusion from which a spectacular swarm of dikes radiates on the northeast to southeast flanks. Low elevations and limited vegetative cover on south-facing slopes provide exceptional exposures, especially for eastern sectors of the volcano. Tracy is the youngest and largest well-defined Conejos center in the map area, with an east-west extent of at least $15 \mathrm{~km}$ at present levels of exposure. Outflow Bonanza Tuff laps out against lower andesite lavas of the volcano along the north flank of this volcano (photo 6.1A), but thick upper lavas of mafic dacite that define the arcuate west flank of the volcano at the head of Tracy Canyon and on Tracy Mountain overlie the Bonanza Tuff along their north margin 
at Sierra de la Lola, south of Laughlin Gulch. Because the volcano is eroded or surrounded by younger deposits, except perhaps on its deeply eroded south side, the exposed extent of the edifice is a minimum for its original basal size.

Tracy volcano is part of a north-northeast-trending chain of at least four pre-ignimbrite central volcanoes, with ages in the range 31.6 - 33.5 Ma, along the west margin of the San Luis Valley from Summer Coon volcano to the south (Lipman, 1968; Mertzman, 1971; Parker and others, 2005) to Jacks Creek to the north (this map). This alignment may constitute a southerly extension of the Sawatch Range ignimbrite-caldera trend of similar age, from Grizzly Peak (34 Ma) to the north to Bonanza (33 Ma). The strong easterly concentration of dikes at Tracy volcano, in contrast to a near-radial distribution at Summer Coon, suggests a stress asymmetry, perhaps involving buttressing by shallow Precambrian basement to the west, comparable to that modeled for dikes at Spanish Peaks, along the east flank of the Colorado Rockies (Odé, 1957). Precambrian rocks are exposed along Saguache Creek just north of Tracy volcano and form rugged paleohills farther north, but the basement geometry beneath Tracy volcano and to the west is poorly known. Presence of such basement rocks at shallow depth would be consistent, however, with southward projection of a high-standing paleo-Sawatch Range.

Intrusions - Varied fine-grained rocks, including numerous dikes of andesite to rhyolite that radiate eastward from an axial stock of granodiorite and intergradational andesite (photo 6.6)

Tyir Rhyolite - Light-gray to tan dikes (76-77\% $\left.\mathrm{SiO}_{2}\right)$, containing $\sim 2-10 \% \mathrm{pl}>$ bi, qtz. Margins of rhyolite dikes are locally glassy and commonly have finely laminated flow layering. In contrast to the numerous easttrending dikes of andesite that appear to predate caldera formation, several rhyolite dikes cut the calderafill andesite (unit Tyca), and a long east-trending central dike cuts through the central intrusion of granodiorite (unit Tyig). Most of the rhyolite dikes are 5-10 m thick, but the large dike that trends north from the head of North Tracy Canyon is as much as $100 \mathrm{~m}$ thick at its proximal (south) end

Tyid Dacite - A few large dikes of phenocryst-rich gray dacite $\left(66-67 \% \mathrm{SiO}_{2}\right)$, containing $15-30 \%$ $\mathrm{pl}>\mathrm{bi}>\mathrm{hbl}$, cpx, which trend to the northeast, parallel to the more abundant dikes of andesite. In places, dacite dikes are difficult to distinguish from steep ramp structures in upper parts of dacite lavas (unit Tyds). Most dacite dikes are 3-15 m wide

Tyia Andesite - Dark-gray dikes (57-58\% $\mathrm{SiO}_{2}$ ), typically containing only small phenocrysts (5-15\%; $\mathrm{pl}>\mathrm{cpx}$, $\mathrm{hbl}$ ). These are the dominant lithology of the strong northeast- to southeast-trending dike swarm (photo 6.6). The andesite dikes typically form subdued exposures that are most evident along ridge crests where host rocks offer a distinct contrast. The light-gray small-phenocryst dacite (unit Tyds) on the sparsely vegetated east flank of Tracy volcano provides an especially contrasting host that helps delimit the extent of these dikes. Many dikes lack outcrops but are marked by trains of andesite boulders and, in places, also by small pinyon pines aligned along dike trends. Even in areas of good exposure, dikes are likely more continuous and numerous than depicted. Where the host rock is andesite or vegetation is thicker, the andesite dikes are accordingly more difficult to identify. The contrasts in dike density are sufficiently well defined, however, to assure interpretation that dike density is much lower in the southeast quadrant of the volcano flank. For example, dikes are completely absent on the sparsely vegetated ridges of crystal-poor dacite adjacent to lower Tracy Canyon. Andesite dikes are present along the rugged rim of the northern volcano flank, but less concentrated than on the eastern flank. The abundance of dikes is less certain on the poorly exposed heavily forested west flank of Tracy volcano, but it is unlikely that many are present, at least at levels cutting the upper sequence of andesite and dacite (units Tyau, Tydu). Typical dike thickness, 0.5-2 m.

Massive intrusive andesite that is similar in appearance to the dikes grades into fine-grained granodiorite (unit Tyig) in the central stock of Tracy volcano. The intrusive andesite differs from the adjacent caldera-fill andesite and lavas on flanks of the volcano in its dense blocky jointing, lack of vesicles or other obvious flow features such as breccia margins, fewer and smaller phenocrysts, and resistance to alteration in comparison to adjacent andesite lavas (unit Tyca)

Tyip Plagioclase andesite - Dark-gray dikes $\left(57.4 \% \mathrm{SiO}_{2}\right)$, containing 10-20\% large plagioclase phenocrysts ( $\mathrm{pl}>\mathrm{cpx}, \mathrm{hbl}$ ); less common than dikes of finer-grained andesite (unit Tyia) in the east-trending swarm, but more numerous than identified on map. Dike thickness, about $1 \mathrm{~m}$

Tyig Granodiorite-Fine-grained equigranular to porphyritic granodiorite (56.8\% $\left.\mathrm{SiO}_{2} ; \mathrm{pl}>>\mathrm{cpx}>>\mathrm{bi}\right)$, grading irregularly into porphyritic andesite. Forms a small stock 0.5 x $0.8 \mathrm{~km}$ across, centrally with Tracy volcano. Patchy acid-sulphate (pyritic) alteration is widespread adjacent to the central intrusion, especially in rhyolitic sedimentary rocks (unit Tysr) in upper North Tracy Canyon northwest of the intrusion

Caldera-filling(?) rocks - Thick lavas of flat-lying massive andesite in the central area between forks of Tracy Canyon are interpreted as fill of a summit caldera about $3 \times 4 \mathrm{~km}$ in area. These lavas lap out abruptly against older lavas of the volcano flanks along steep inward-dipping slopes that are interpreted as remnants of the caldera walls. Explosively erupted pyroclastic rocks or other deposits that could have been associated with formation of the caldera have not been positively identified. 
Possibly caldera subsidence could have been related to eruption of one or more of the large-volume small-phenocryst dacite lavas now exposed on the east flank. Filling of the caldera basin by the andesitic lavas appears to have been rapid; no interlayered lacustrine deposits were found, only a few small areas of scattered float of fluviatile conglomerate. The caldera-filling(?) lavas are intruded by the central granodiorite and by rhyolite dikes, but the caldera and its fill appear to postdate the swarm of intermediate-composition dikes that cut the east flank of the volcano

Caldera andesite - Thick massive lavas of light-gray to tan-brown andesite and some mafic dacite (mostly 60-64\% $\mathrm{SiO}_{2}$ ) in central area of volcano between North and South Tracy Canyons, commonly containing small phenocrysts of plagioclase and hornblende. In contrast to adjacent flank lavas, the caldera lavas are typically dense, contain only sparse small vesicles, lack voluminous flow breccia, and tend to form angular joint blocks as float. These flows lap out abruptly against older lavas of the volcano flanks along steep inward-dipping slopes that are interpreted as remnants of the caldera wall. Red-brown-weathering outcrops along South Tracy Canyon are nearly aphyric, have relatively coarse groundmass textures, and are characterized by closely spaced rectilinear joints; these are probably parts of a thick ponded flow but could be an intrusive sill. Thickness of individual caldera-filling lavas, as much as $40 \mathrm{~m}$; total exposed thickness, $>200 \mathrm{~m}$

Tydt Dacite caldera-wall talus - Crudely bedded massive breccia, derived from the small-phenocryst dacite lava (unit Tyds), crops out along the unconformity interpreted to mark the northeast wall of the central caldera, near the westward bend of North Tracy Canyon (photo 6.4D). The breccia consists of monolithologic dacite blocks, ranging in size from centimeters to meters, in a matrix of microbreccia of the same composition. Where well developed, bedding in the breccia dips inward toward the caldera and is parallel to inferred inner slopes of the caldera wall. In other places, the breccia is massive and difficult to distinguish from primary carapace breccia of dacite lavas, but such flow breccia is not widely developed or preserved elsewhere in the small-phenocryst dacite. A contrasting caldera-margin volcaniclastic deposit is a small patch of well-bedded centimeter-size angular blocks and chips of fine-grained dacite in a sandy matrix, dipping gently but banked against a massive exposure of the dacite along the east caldera wall near the junction of North and South Tracy Canyons (photo 6.4A). Breccia thickness, 10-50 m

Tyat Andesite caldera-wall talus and landslide breccia - Chaotic blocks of texturally diverse andesite as much as several meters across, along with minor dacite and sparse chips of rhyolite. Forms an isolated hill (elev 8,865', eastern LG) in North Tracy Canyon, between the ponded intracaldera andesite (unit Tyca) and diverse andesite lavas of the northwest volcano flank. Exposed mostly as loose rubble; indurated blocks of angular andesite form small outcrops high on north slope of this hill. Interpreted as caldera-related talus and landslide deposit, based on location and on lithologic contrast with other nearby deposits of the Tracy volcano

Flank lavas-The outward-dipping flanks of Tracy volcano contain thick lava sequences of diverse composition, from high-silicic rhyolite to dark fine-grained andesite

Tyv Volcaniclastic rocks - Volcaniclastic rocks, other than primary flow-breccia margins of lavas, are rare on exposed flanks of the Tracy volcano. Small areas of andesitic laharic breccia and conglomerate are poorly exposed on lower slopes adjacent to upper North Tracy Canyon, and fluvial conglomerate occupies upper slopes of a conical hill (elev $\sim 8,400^{\prime}$ ) south of lower Tracy Canyon (SG). The scarcity of such volcaniclastic rocks indicates that exposed levels are high on the proximal slopes of the volcanic edifice. Maximum thickness, $<35 \mathrm{~m}$

Tydu Upper dacite - Thick sequence of gently dipping lavas of phenocryst-rich mafic dacite, transitional to andesite $\left(\sim 61-64 \% \mathrm{SiO}_{2} ; 15-25 \% \mathrm{pl}>>\mathrm{bi} \pm \mathrm{cpx}, \mathrm{hbl}\right)$ along high arcuate ridge from Sierra de la Lola to Tracy Mountain (LG; photo 6.1A). Basal breccias, vitrophyre zones, and flow layering are common. Some finely porphyritic lavas of this unit as mapped contain only sparse biotite and likely are silicic andesite. Overlies Bonanza Tuff on north slope of Sierra de la Lola. Some lavas may be equivalent to porphyritic andesite and dacite (Tba), mapped as part of the Bonanza caldera cycle across Laughlin Gulch to the north. Biotite ${ }^{40} \mathrm{Ar} /{ }^{39} \mathrm{Ar}$ age of $33.71 \pm 0.10 \mathrm{Ma}$ for a lava on southwest flank of Tracy Mountain is at least $0.5 \mathrm{~m}$.y. too old, an intermittent problem with biotite phenocryst ages in the SRMVF and elsewhere (McIntosh and Chapin, 2004; Lipman and McIntosh, 2008; Hora and others, 2010). Thickness of individual flows, as much as $50 \mathrm{~m}$; maximum preserved thickness of dacite sequence, $>300 \mathrm{~m}$

Tyau Upper andesite - Flows of fine-grained gray silicic andesite and mafic dacite (59-63.8\% $\mathrm{SiO}_{2}$ ) that lack conspicuous phenocrysts, interlayered with the upper dacite (unit Tydu) on west flank of the volcano at Tracy Mountain. A thick sequence of dense dark lavas that underlie the upper dacite along the southeast flank of Tracy Mountain are included in the upper andesite unit, based on an abrupt contact with more-altered flank andesite (Tya) at lower elevation, representing a probable 
unconformity that may be correlative with the horizon occupied by Bonanza Tuff north of Sierra de la Lola. A fine-grained flow of mafic dacite that interfingers with porphyritic upper dacite and caps Tracy Mountain has a ${ }^{40} \mathrm{Ar}{ }^{39} \mathrm{Ar}$ age of $31.58 \pm 0.09 \mathrm{Ma}$ (groundmass separate). Thickness, $0-100 \mathrm{~m}$ Plagioclase andesite - Distinctive coarsely porphyritic dark-gray lavas $\left(56-60 \% \mathrm{SiO}_{2} ; 15-25 \% \mathrm{pl}>>\mathrm{cpx}\right)$, characterized by tabular phenocrysts of plagioclase as much as $1 \mathrm{~cm}$ across (photo 6.3). Massive north-dipping succession of chaotically bedded lavas and flow breccia, commonly highly vesicular and variably oxidized, is more than $300 \mathrm{~m}$ thick on the high rugged ridge, locally known as the "Devil's Backbone," between Tracy and Saguache Creeks (SG). This main area of plagioclase andesite is underlain and overlain by small-phenocryst dacite (unit Tyds) to the east and overlain by fine-grained andesite along the eroded north flank of Tracy volcano

Tyds Small-phenocryst dacite - Several thick lavas of petrographically distinctive finely porphyritic light-gray dacite (photo $6.4 ; 66-68 \% \mathrm{SiO}_{2} ; 5-10 \%$ plag $>$ bi). These lavas were singled out and described briefly as the Tracy Creek quartz latite by Larsen and Cross (1956, p. 86-87). In contrast to other silicic dacites in the map area that are more coarsely porphyritic, phenocrysts in these flows are sparser and smaller, commonly $1-2 \mathrm{~mm}$; the biotite is typically oxidized and bronzy in color; and other mafic minerals (cpx, hbl) and sanidine are absent. In places, biotite phenocrysts make elongate rather than equant tablets, almost resembling hornblende. Much of the small-phenocryst dacite is flow layered and characterized by schistose-like hackly fracturing on fine scale, a reflection of aligned groundmass plagioclase microlites that define a felty trachytic fabric (photos 6.4B,C). In places, this dacite is light colored and flow laminated, almost resembling rhyolite; in others, darker and more massive rock resembles silicic andesite. The only broadly similar dacites elsewhere in the map area are a local lava (unit Tjds) on the northeast flank of Jacks Creek volcano in lower Bear Creek (LMNE) and the younger dacite (unit Tbfh) that caps Hayden Peak (WH). A thick lower lava, or succession of several flows of the small-phenocryst dacite, forms much of the east flank of Tracy volcano at exposed levels; it is overlain by plagioclase andesite (unit Tyap) and then by fine-grained andesite (unit Tya) at higher levels on the outmost preserved flanks (photo 6.1B). On the southeast side of Tracy volcano, the lower unit of small-phenocryst dacite laps out against the coarsely porphyritic dacite of Red Rock Canyon and is overlain by distinctive lavas of quartz-xenocrystic andesite south of Tracy Canyon. An upper thick flow of similar small-phenocryst dacite overlies the bulk of the flanking andesite (unit Tya) along the northeast end of the Devils Backbone ridge and, in turn, is overlain by erosional remnants of stratigraphically higher fine-grained andesite at Devils Knob and ridges to the south (photo 6.1B). The contact between the upper lava of small-phenocryst dacite and overlying andesite is beautifully exposed in deep roadcuts along Hwy 285 about $4 \mathrm{~km}$ south of Saguache. Biotite from the dacite along South Tracy Canyon yielded a ${ }^{40} \mathrm{Ar} /{ }^{39} \mathrm{Ar}$ plateau age of $33.55 \pm 0.09 \mathrm{Ma}$, consistent with its inferred stratigraphic position beneath the Bonanza Tuff. Maximum thickness, $>300 \mathrm{~m}$

Tya Andesite - Texturally diverse lavas of fine-grained andesite, interfingering with dacite at several stratigraphic levels on flanks of Tracy volcano (photos $6.1 B, 6.2)$. Most lavas are finely porphyritic ( $\sim 56-$ $61 \% \mathrm{SiO}_{2} ; 5-10 \%$ small $\left.\mathrm{pl}>>\mathrm{cpx} \pm \mathrm{hbl}\right)$; some flows have minor biotite; others are virtually aphyric. Some finely porphyritic lavas mapped with this unit may have mafic dacite compositions. Most andesite lavas are vesicular, at least at margins, but these rocks are more dense, better stratified, and associated with less flow breccia than the plagioclase andesite (unit Tyap) at Tracy volcano. The uppermost lava of fine-grained andesite at the mouth of Tracy Creek is overlain by a tiny knob of Fish Canyon and Carpenter Ridge Tuffs, but Bonanza Tuff is everywhere absent above these flows along the east flank of Tracy volcano. Accordingly, the possibility exists that upper parts of this undated andesite sequence could be younger than the Bonanza eruptions. Alternatively, exposed levels of the east flank of Tracy volcano, which appears to be tilted about $5-10^{\circ}$ eastward into the San Luis Valley segment of the Rio Grande rift, originally may have stood too high to be covered by an ignimbrite from Bonanza caldera. Andesite lavas and breccia along the southwest margin of the map area (LG) are of uncertain relation to Tracy volcano; these alternatively could have been mapped as undifferentiated andesite of the Conejos Formation (unit Tca). Individual lavas are typically 10-20 m thick; maximum preserved thickness, $>150 \mathrm{~m}$ south of Tracy Canyon

Tyaq Quartz-xenocrystic andesite-Thick lavas of distinctive light-gray sparsely porphyritic silicic andesite or dacite $(5-10 \% \mathrm{pl}>\mathrm{hbl}, \mathrm{qtz})$, characterized by resorbed quartz crystals as much as several $\mathrm{mm}$ in diameter. Lowest andesitic flows along south caldera wall, low on ridges north of survey point "Alexander" (SG). Banks against dacite of Red Rock Canyon (unit Tyd), and overlain by finegrained andesite (Tya). Exposed thickness, $>100 \mathrm{~m}$

Tyab Andesite breccia-Massive weakly stratified breccia, consisting of angular fragments of nearly aphanitic gray andesite, as much as a few tens of centimeters in size, on the south slope of Tracy Mountain. 
Tyfr

Tysr

Tyd

Tydb
Inferred to constitute primary cone breccia, but unclear whether it is part of Tracy volcano or the flank of a separate eruptive center to the southwest. Appears to overlie dacite of Red Rock Canyon (unit Tyd) along steep northwest-facing slope north of San Juan Creek. Maximum exposed thickness, $>150 \mathrm{~m}$

Rhyolite - Several thick lavas of light-gray phenocryst-poor flow-laminated rhyolite lava $\left(76-77 \% \mathrm{SiO}_{2}\right.$; $3-10 \% \mathrm{pl}>\mathrm{qtz}, \mathrm{bi} \pm \mathrm{sn})$ are present low in the exposed sequence of flank lavas at Tracy volcano. Paleohills of one or more rhyolite lavas crop out for a distance of more than $1 \mathrm{~km}$, beneath small-phenocryst dacite in an unnamed valley east of North Tracy Canyon. Steeply dipping flow-layered ramps indicate that the exposed levels are near the top of this unit. A marginal glassy zone yielded ${ }^{40} \mathrm{Ar} /{ }^{39} \mathrm{Ar}$ ages of $33.17 \pm 0.12$ $\mathrm{Ma}(\mathrm{sn})$ and $34.11 \pm 0.69 \mathrm{Ma}$ (biotite plateau, probably anomalously old), providing a limiting age for lower parts of the lava sequence on the northeast flank of Tracy volcano that just predates ignimbrite eruption from Bonanza caldera. Sanidine from carapace breccia of a rhyolite lava in lower San Juan Creek (SG) yielded a slightly earlier age, $33.46 \pm 0.08 \mathrm{Ma}$. A thick remnant of an eroded rhyolite lava dome forms an isolated hill more than $200 \mathrm{~m}$ high that underlies andesite on the north flank of Tracy volcano, just west of the Campo Santo Cemetery (SG). Another paleohill of nearly aphyric rhyolite lava (southeast corner, LG) projects through cover by the dacite of Red Rock Canyon (unit Tyd)

Rhyolitic sedimentary rocks - Bedded tuffaceous sandstone, conglomerate, and probable thin layers of ash-fall and nonwelded pyroclastic-flow rhyolite are overlain by andesite lavas (unit Tya) along upper North Tracy Creek. Intensely silicified and otherwise altered in most exposures, in places forming boldly outcropping knobs of nearly pure silica, where original lithology has been obliterated. Probably flanking and reworked fragmental deposits associated with primary rhyolite lavas in adjacent areas. Exposed thickness, $>125 \mathrm{~m}$

Dacite of Red Rock Canyon - Distinctive reddish-brown to gray crystal-rich dacite $\left(64-67 \% \mathrm{SiO}_{2} ; 20-30 \%\right.$ pl $>>b i>c p x$ ), which forms a thick sequence of lavas along the south margin of the map (photo 6.5), is the oldest volcanic rock exposed along the south flank of Tracy volcano. Several types of andesite and the overlying small-phenocryst dacite (unit Tyds) all lap out against the crystal-rich dacite, which forms spectacular rugged cliffs just south of the map area in Red Rock Canyon (SC), the next valley south of Tracy Creek. Gray dacite that forms massive outcrops in lower San Juan Creek (SC) has similar phenocryst contents but is characterized by locally abundant small inclusions of incompletely mingled fine-grained andesite (photo 6.5). In some outcrops, angular andesite inclusions in flow-foliated matrix dacite appear misleadingly similar to lithic-bearing welded tuff. These thick lavas may constitute the south flank of Tracy volcano or, alternatively, northern parts of another edifice centered south of the map area. They are the northernmost part of a large area of dacite lavas that have been described briefly as the Beidell Creek quartz latite (Larsen and Cross, 1956, p. 86-87), but determining their relation to the eruptive center and associated intrusive complex in Beidell Creek to the south requires further study. Two samples, from lavas south of Tracy Creek that are continuous into Red Rock Canyon, have ${ }^{40} \mathrm{Ar} /{ }^{39} \mathrm{Ar}$ ages of $33.56 \pm 0.09$ and $34.09 \pm 0.26 \mathrm{Ma}$ (biotite plateaus). Two more samples, from the andesite-inclusion flow in lower San Juan Creek, have ${ }^{40} \mathrm{Ar}{ }^{39} \mathrm{Ar}$ ages of $33.46 \pm 0.08$ and $33.50 \pm 0.09 \mathrm{Ma}$ (biotite plateaus), providing consistent results for these early eruptive units. An additional sample from Red Rock Canyon yielded a biotite ${ }^{40} \mathrm{Ar} /{ }^{39} \mathrm{Ar}$ age of $30.66 \pm 0.11 \mathrm{Ma}$ that is clearly too young, perhaps because this biotite is rather oxidized

Dacite lavas-Massively flow layered lava, making rugged exposures along south margin of map area near boundary between LG and SG quadrangles. Exposed thickness, $>400 \mathrm{~m}$

Dacite breccia-Dark-gray glassy and near-glassy blocks of dacite in a microbreccia matrix of the same material, forming basal and upper carapace deposits at margins of flow-layered interior dacite. Only locally sufficiently thick and well exposed to map separately

\section{Sargents Mesa Volcano}

A thick sequence of finely porphyritic tan andesite transitional to mafic dacite, on the east side of Sargents Mesa $(\mathrm{CH})$ along the west margin of the Bonanza map area, is interpreted as the flank of a central volcano that lies mainly farther west. The Sargents Mesa volcano also contains early- and late-erupted lavas of phenocryst-poor rhyolite and minor coarsely porphyritic dacite, in addition to the dominant volume of fine-grained lavas of intermediate composition (Lipman, 2012); only the fine-grained andesite-dacite lavas are present within the Bonanza map area. Step-heating plateau and integrated ${ }^{40} \mathrm{Ar} /{ }^{39} \mathrm{Ar}$ ages for groundmass and biotite from three lavas are in the range 32.85-33.28 Ma, with a weighted mean of $32.99 \pm 0.15 \mathrm{Ma}$, analytically indistinguishable from that of Bonanza Tuff. Several of the analyses are characterized by complex spectra and young ages from low-temperature steps, suggesting these lavas may have erupted earlier than suggested by the measured ages. Nonwelded rhyolitic tuff, poorly exposed as float in a small area centrally on the mesa (just west of the map area), has yielded ages of $32.72 \pm 0.02$ and $32.83 \pm 0.03 \mathrm{Ma}$ (sn), providing an upper limit for Sargents Mesa eruptions. Bonanza Tuff laps out against the north and southeast flanks of Sargents Mesa, confirming accumulation 
of most lavas on the mesa just prior to eruption of this ignimbrite. Stratigraphic relations between the tan andesite-dacite of the Sargents Mesa volcano and older porphyritic dacite (Tmd) of Marshall caldera cycle are obscure on the timbered north slopes of Sargents Mesa; east of Long Gulch (SM), the porphyritic dacite overlies fine-grained andesite that has not been distinguished from the andesite-dacite capping Sargents Mesa (Lipman, 2012).

A large variably-altered intrusion of porphyritic dacite, grading into fine-grained granodiorite, and exposed at roof level in the headwaters of Long Branch (SM), is interpreted to mark the core of this volcano, which occupies much of the Sargents Mesa quadrangle (Lipman, 2012). ${ }^{40} \mathrm{Ar} /{ }^{39} \mathrm{Ar}$ ages (hornblende, biotite) of $33.01 \pm 0.10 \mathrm{Ma}$ (bi) and $33.02 \pm 0.19 \mathrm{Ma}(\mathrm{hbl})$ from an unaltered marginal facies of the central intrusion suggest that this body is a late intrusive phase of the Sargents Mesa volcano.

The eastern termination of the Sargents Mesa accumulation was initially interpreted as the partly buried west margin of Marshall caldera; location of the semi-arcuate north-northeast-trending contact (southwestern $\mathrm{CH}$ ) with dark post-Bonanza andesitic lavas (unit Tbam) seemed plausibly interpreted as a caldera-wall unconformity, but isotopic ages demonstrate that eruption of the Sargents Mesa lavas accumulation postdated Marshall caldera and was close in time to the Bonanza cycle. Most plausibly, the inadequately studied Sargents Mesa volcano erupted from vents near the west margin of Marshall caldera, as an immediate precursor to the culminating ignimbrite eruption of the Bonanza cycle.

Tsa Andesite-dacite lava-Gently dipping flows of finely porphyritic tan to pinkish-brown andesite and mafic dacite $\left(57.7-63.0 \% \mathrm{SiO}_{2} ; 5-10 \%\right.$ small $\mathrm{pl}>>\mathrm{hbl}$, bi). These oxidized lavas are onlapped by Bonanza Tuff along the north side of Sargents Mesa and by dark post-Bonanza andesite (unit Tbam) along a linear zone west of Tank Seven Creek $(\mathrm{CH})$ and continuing across the Continental Divide to the south, which may reflect structures related to the concealed west margin of Marshall caldera. Several biotite groundmass ages from the andesite-dacite lavas have somewhat inconsistent and puzzling ${ }^{40} \mathrm{Ar} /{ }^{39} \mathrm{Ar}$ ages of $32.85-33.29 \mathrm{Ma}$ (average, $32.99 \mathrm{Ma}$ ) that are unexpectedly young; they require emplacement after eruption of the Thorn Ranch Tuff from Marshall caldera at 33.9 Ma and just preceding the Bonanza Tuff, rather than forming part of Marshall caldera wall. Individual flows as thick as $30 \mathrm{~m}$; total exposed thickness, $>600 \mathrm{~m}$

\section{Rawley Volcanic Complex ( 33.2-33.8 Ma)}

Lower parts of the regional Conejos Formation that are widespread east and south of Marshall caldera, where they are overlain by the Bonanza Tuff in the vicinity of Bonanza caldera, have long been designated the Rawley Andesite (Burbank, 1932). These rocks, including porphyritic dacite and rhyolite lavas, as well as dominant volumes of silicic andesite, define the eroded remnants of a large high-standing cluster of related volcanic centers (photo 5), central parts of which were caved away by collapse of Bonanza caldera (Varga and Smith, 1984). As currently mapped, basal rocks of the Rawley complex occupy an equant area about $30-35 \mathrm{~km}$ in diameter, roughly similar in size to Mount Shasta, the largest edifice in the Cascade Range and also a complex of at least four overlapping eruptive sequences (Christiansen and Miller, 1989).

On several flank sectors, the Rawley assemblage displays a general stratigraphic sequence that becomes more silicic upward: from relatively fine-grained andesite with small plagioclase and hornblende phenocrysts to more porphyritic and silicic lavas, dark porphyritic andesite containing large blocky phenocrysts of plagioclase but little or no biotite, smallphenocryst biotite dacite, then more coarsely porphyritic lighter-colored biotite dacite, and, in places at highest levels, sanidine-bearing dacite or crystal-poor rhyolite. Gradations in texture and phenocryst content between mapped lava lithologies are common, and some contacts separate lava packages that differ only modestly. Some units also include other subordinate lithologies, which interfinger on scales too small or too poorly exposed to separate at map scale.

Growth of the Rawley complex is constrained between about 33.2 and $33.8 \mathrm{Ma}$, even though few rocks could be dated directly with adequate precision: sanidine-bearing units are rare, and many rocks are propylitically or otherwise altered. Along the eastern mountain front between Cottonwood and Kelly Creeks (WH), rocks of the Rawley volcanic complex overlie ignimbrite interpreted as proximal outflow Thorn Ranch Tuff (33.9 Ma) and are overlain by intracaldera Bonanza Tuff. Early rhyolitic lava of the Rawley complex, at the head of McIntyre Gulch (GG), has yielded the oldest sanidine ${ }^{40} \mathrm{Ar} /{ }^{39} \mathrm{Ar}$ ages from deep in this assemblage: $33.87 \pm 0.11 \mathrm{Ma}$ (avg, two dates). Sanidine-bearing dacites on the west flank of the Rawley complex have ages of 33.56 to 33.66 (two dated samples). Andesite lavas in the Ute Pass area (KM) on the south rim of Bonanza caldera have yielded several younger groundmass plateau ages, 33.3533.45 Ma, indicating continued eruptive activity until shortly before eruption of the caldera-forming ignimbrite. As such, early parts of the Rawley complex are similar in age to the postcaldera volcanic rocks of the Marshall cycle, and mapped distinctions between the two assemblages are somewhat arbitrary, especially in the tributaries of upper Middle Creek that lie within the inferred buried southeastern parts of Marshall caldera.

Interpretation of the Rawley rocks is complicated by relatively poor exposures on heavily vegetated slopes at higher elevations, common development of thick massive lava units without widespread sedimentary interbeds that could help define stratigraphic sequences, emplacement of lavas on highly irregular paleotopography and resulting poorly layered rock sequences, and intense hydrothermal alternation in places adjacent to intrusive centers and within Bonanza caldera that complicates even simple lithologic identification. 
Intrusions - Small intrusions of fine-grained mafic granodiorite at the Klondike Mine and at Spook City $(\mathrm{KM})$ and a dacite plug along the eastern mountain front $(\mathrm{WH})$ are the only mapped intrusive rocks identified as likely vents for the Rawley complex. Some dikes and larger bodies within the Bonanza caldera area, mapped as intrusions of uncertain affinity, are likely of Rawley age, but many of these are more likely related to postcaldera resurgence. Some intrusive andesites mapped as satellitic outliers of the Turquoise Mine intrusion may alternatively be of Rawley age, although the location of these intrusions in the core of the caldera resurgent dome and proximity to dated phases of the Turquoise Mine intrusion favor a postcaldera age

Trig Granodiorite-Small stocks of fine-grained dark granodiorite (pl, cpx, minor bi), about $400 \mathrm{~m}$ across near the Klondike Mine and at Spook City (KM), are associated with intense supergene acid-sulfate alteration in adjacent country rocks. These undated intrusions also lie close to the southeast margin of Marshall caldera, and they could equally well be interpreted as associated with postcaldera volcanism of that caldera cycle. Granodiorite at the Klondike Mine has well-developed rectilinear jointing, weathering to rounded sandy-surfaced blocks. The intrusion at Spook City is more porphyritic, perhaps a holocrystalline equivalent to porphyritic andesite (unit Trap). Granular quartz rock in a small gully on the north side of the Spook City intrusion may be contact-metamorphosed sandstone, but was not studied in detail

Trid Dacite - Only two probable intrusions of this age were recognized. A rugged knob of dark mafic dacite $\left(61.1 \% \mathrm{SiO}_{2}\right.$ ), containing $25 \%$ large phenocrysts (to $5 \mathrm{~mm}$ ) of blocky plagioclase, biotite, and clinopyroxene, appears intrusive into more mafic-appearing plagioclase andesite (unit Trap) on the south side of upper Rawley Creek (WH) but might alternatively be part of a thick flow. A semicircular plug of gray-brown dacite $\left(67.6 \% \mathrm{SiO}_{2} ; 20 \% \mathrm{pl}>\right.$ bi, sn), about $150 \mathrm{~m}$ in diameter on the west side of lower Cottonwood Gulch (GG), intrudes the Pennsylvanian Sharpsdale Formation and contains steeply dipping concentric flow layering in its outer parts. Although on the east flank of the Bonanza resurgent dome and in proximity to dacitic lavas mapped as part of the Rawley volcanic complex, this intrusion yielded ${ }^{40} \mathrm{Ar} /{ }^{39} \mathrm{Ar}$ ages of $33.82 \pm 0.11 \mathrm{Ma}(\mathrm{sn})$ and $33.94 \pm 0.14 \mathrm{Ma}$ (biotite) that are more aligned with the Marshall cycle. Either the Rawley complex evolved over an extended period, initially constituting late volcanism of the Marshall cycle, or the Cottonwood plug represents a local early intrusion, unrelated to growth of the Rawley complex

Lavas and related rocks - Compositionally diverse lavas define a composite volcanic highland, within which Bonanza caldera is nested. Precaldera rocks of the Rawley complex merge to the west and north with postcollapse lavas of Marshall caldera

Trv Volcaniclastic rocks-Mostly reworked crudely bedded to well-bedded conglomerates, sandstones, and mudflow breccias, containing clasts of dark andesite and dacite in light-gray sandy matrix. Primary dips are typically $<5^{\circ}$. Mainly distal deposits on lower slopes of volcanic constructs; most abundant on the southwest and south flanks of the Rawley complex. Much less voluminous, relative to proximal lavas, than in preserved rocks of the Conejos Formation farther west and south in the San Juan region

Trfr Rhyolite - Scattered erosional remnants of light-gray crystal-poor lava (typically 2-5\% plag $>>$ bi), commonly having well-developed flow layering, interfinger with more mafic lavas of the Rawley complex. Several of these are stratigraphically high, and some ambiguity persists whether they are most appropriately part of the Rawley complex or precursors of the Bonanza caldera cycle. Most of the rhyolites lack sanidine, and thus cannot be dated directly. Some areas mapped as rhyolite, especially in upper Cottonwood Creek and north of Peterson Creek (WH), may alternatively be intensely bleached silicified andesite (unit Tra); such distinctions were challenging in poorly exposed areas of strongly altered rocks within Bonanza caldera. Much of the exposed rhyolite lies along a northeasttrending zone, which projects through the center of Bonanza caldera, obliquely to the subsequent resurgent dome that trends elliptically northward. This trend is well displayed by other major structures in the northeastern San Juan region such as the large Needle Creek intrusive complex, the Los Pinos and Cochetopa grabens (Lipman, 2012), and the Eagle Gulch intrusion at Bonanza.

Several areas of flow-layered crystal-poor rhyolite that overlie andesite lavas on the Bonanza caldera floor along Kerber Creek may record inception of the Bonanza caldera cycle or just represent late eruptions from the Rawley volcanic complex. Small hill-capping remnants of phenocryst-poor sanidine-bearing rhyolite along both sides of Kerber Creek just west of the junction with Little Kerber Creek (GG) are massive to flow layered but locally contain fiamme-like textures and sparse andesite fragments, especially close to the base of the unit. Two relatively unaltered samples from this area yielded ${ }^{40} \mathrm{Ar} /{ }^{39} \mathrm{Ar}$ ages (sn) of $33.79 \pm 0.02$ and $33.83 \pm 0.02 \mathrm{Ma}$. Even though stratigraphically high in the Rawley lava sequence, these ages suggest close temporal affinity of the rhyolite, and perhaps much of the Rawley volcano, with postcollapse eruptions associated with Marshall caldera. 
The large area of highly altered crystal-poor rhyolite centered along Greenback Gulch, on the northeast side of Kerber Creek (GG, BZ), described as a shallow volcanic neck by Burbank (1932), is interpreted as another part of this unit but is too altered to permit age determinations or reliable rock chemistry. Several mineral-exploration drill holes in the 1950s penetrated andesitic lavas (unit Tra) beneath this rhyolite (Cook, 1960), documenting a thick extrusive flow-dome, rather than an intrusion. Consistent with such an interpretation, pumiceous breccia is preserved locally along eastern surface contacts of this body, especially on the slope northwest of Express Creek.

An outlying sizable area of rhyolite, overlain by andesite lavas at the head of Graveyard Gulch (GG), contains sparse high-K sanidine ( $\left.\mathrm{Or}_{69-71} \mathrm{Ab}_{26-27} \mathrm{An}_{0.5-1.0} \mathrm{Cn}_{2-3}\right)$ that differs in composition from rhyolitic Bonanza Tuff (much higher $\mathrm{K}$ and $\mathrm{Ba}$ ) and has yielded ${ }^{40} \mathrm{Ar} /{ }^{39} \mathrm{Ar}$ ages of $33.80 \pm 0.07$ and $33.87 \pm 0.11 \mathrm{Ma}$ (two samples). Even though located far to the south, these samples have ages close to that for postcollapse volcanism of the Marshall caldera cycle, adding support to the inference that early parts of the Rawley complex have eruptive continuity with the preceding caldera cycle.

Rhyolite lavas that are overlain by Bonanza Tuff at the mouth of Clover Creek (WH) and along the east mountain front between Peterson and Turquoise Gulches contain only sparse small crystals of plagioclase and biotite, unlike initially erupted sanidine-bearing rhyolitic Bonanza Tuff, and thus cannot be dated readily. These most likely represent late eruptions from the Rawley volcanic complex but, alternatively, could have resulted from highly rheomorphic early pyroclastic eruptions and thus be equivalent to small erosional remnants of such rocks (unit Tbrr) within the caldera to the southwest.

Voluminous rhyolite of the Rawley complex, sandwiched between dacite and andesite lavas, surrounds the granodiorite intrusion at the Klondike Mine (KM) and is affected by the hydrothermal alteration adjacent to this intrusion. Lithologically similar rhyolite caps ridges in an outer arcuate subsided caldera block, north of Little Kerber Creek (KM). This area of silicic lava is stratigraphically higher, in close proximity to small erosional remnants of Bonanza Tuff along the southwest caldera wall, but it is locally capped by plagioclase andesite, indicating that it is appropriately included with the Rawley assemblage rather than an early phase of the Bonanza eruption.

Crystal-poor rhyolite on the east flank of the Bonanza resurgent dome, along the east mountain front between Peterson and Turquoise Creeks (WH), is widely altered and in places difficult to distinguish from adjacent altered andesite. This rhyolite is the stratigraphically highest volcanic rock in the area, and its genetic relation to the Rawley volcanic complex versus the Bonanza caldera cycle remains uncertain. Analogous interpretive problems apply to the smaller areas of poorly exposed rhyolite low along both sides of Clover Creek to the north (WH, PO)

Trt

Trdk

Trdx
Rhyolite tuff - Weakly indurated rhyolitic ash that is variably altered and poorly exposed beneath Bonanza Tuff in small areas along Dry Gulch (KM) likely represents distal pyroclastics and reworked facies associated with a rhyolite flow centered to northeast in upper Findley Gulch. Thickness, $>50 \mathrm{~m}$

Sanidine-bearing dacite - Several lavas of light-gray sanidine-bearing dacite $\left(\sim 65-68 \% \mathrm{SiO}_{2} ; 20-25 \%\right.$ $\mathrm{pl}>\mathrm{bi}, \mathrm{sn} \pm \mathrm{cpx}, \mathrm{hbl}$ ) have been distinguished from other dacites of the Rawley complex, mainly along Tuttle Creek (KM, BZ). The sanidine crystals are small, sparse, and identifiable only with difficulty in hand sample, but thin sections confirm that many other large areas mapped as dacite (unit Trd) indeed lack sanidine. Groundmass of the sanidine dacite in lower Tuttle Creek, near the junction with Ford Creek (LMNE) is silicified and highly oxidized to red-brown colors, but the phenocrysts appear unaffected and a sanidine ${ }^{40} \mathrm{Ar} /{ }^{39} \mathrm{Ar}$ age is $33.56 \pm 0.02 \mathrm{Ma}$. Alteration of this dacite is in proximity to the projected southeast margin of Marshall caldera, as partly constrained by paleohills of Proterozoic granitic rocks. Less altered dacite at the head of Mill Gulch (KM), perhaps part of the same flow, has a ${ }^{40} \mathrm{Ar} /{ }^{39} \mathrm{Ar}$ age (sn) of 33.66 $\pm 0.09 \mathrm{Ma}$. A stratigraphically higher flow of sanidine dacite, on the south slope of Baxter Mountain north of Tuttle Creek (BZ), yielded an unexpectedly young ${ }^{40} \mathrm{Ar} /{ }^{39} \mathrm{Ar}$ age (sn) of $33.00 \pm 0.02 \mathrm{Ma}$; this flow thus appears to be a small erosional remnant of postcaldera dacite (unit Tbfd), rather than interlayered with the sequence of Rawley lavas. Although the older dacite lavas were emplaced on the southwest flank of the Rawley constructional edifice, the ages are also consistent with postcollapse filling of Marshall caldera. Maximum thickness of individual lavas, $>200 \mathrm{~m}$

Dacite shatter breccia-Distinctive shattered dacite, derived from the main unit of dacite lavas (unit Trd). Exposed discontinuously on each side of Kerber Creek up valley from junction with Little Kerber Creek and also along Columbia Gulch to the south (GG). Angular blocks mostly $<1 \mathrm{~m}$ across are juxtaposed, with only minor matrix of pulverized dacite. In many exposures, finely shattered fragments of dacite fit together without large-scale rotation or other movement, and such rocks grade into less shattered dacite away from mapped ring faults. Although fault planes, slickensides, or other evidence of faulting are rare, these breccias are in close proximity to the main caldera-collapse ring 
fault that occupies the valley of Kerber Creek and are interpreted as highly shattered wall rocks, analogous in origin to that proposed for the shattered andesite lavas (unit Trax) that occur adjacent to caldera ring faults in the same areas

Dacite - Crystal-rich gray to red-brown dacite lavas ( $\left.\sim 63-66 \% \mathrm{SiO}_{2} ; 20-30 \% \mathrm{pl}>\mathrm{bi}, \mathrm{cpx} \pm \mathrm{hbl}\right)$ are much less voluminous than andesite in the Rawley complex, but these distinctly porphyritic rocks are some of the most readily mappable units in the pre-Bonanza volcanic sequence. Large plagioclase and biotite phenocrysts (to $5 \mathrm{~mm}$ ) are characteristic. A few dacite lavas of the Rawley complex that contain sparse sanidine and have been mapped separately (unit Trdk) where recognized. The dacite typically forms thick massive lavas, in places, with black vitrophere and glassy flow breccia at flow bases, and large-scale flow layering is present locally in lower and upper parts of emplacement units. Devitrified lava interiors are massive and form large rounded boulders due to mechanical weathering of the granular texture. Steeply dipping flow layering and ramp structures are common near tops of lavas. Distal portions of some coarsely porphyritic dacite lavas become finer grained and merge in character with the unit of small-phenocryst dacite (unit Trds). One large dacite lava caps the ridge south of Columbia Gulch (GG) that constitutes the eroded southwest caldera topographic rim; downdropped parts of this flow are directly overlain by Bonanza Tuff. Erosional remnants of similar dacite are preserved widely beneath Bonanza Tuff on outer slopes of the west caldera rim and cap large ridges farther west towards Middle Creek (KM). These dacites are likely within the buried southern extent of Marshall caldera; although mapped as part of the Rawley complex, they could alternatively have been designated as fill of the older caldera. A large dacite lava is also exposed at the base of the southeastern caldera-floor volcanic sequence, in the vicinity of Cody Gulch and lower Cottonwood Creek and probably continuing south into the Kerber valley (WH, GG). Another mapped area of massive dacite, in proximity to intrusive andesite (unit Tta) higher along Cottonwood Creek (WH), may alternatively be a dacite porphyry phase of the Turquoise Mine intrusion or an outlier of Eagle Gulch Dacite (unit Ted). None of these dacite lavas has been dated directly, but several are bracketed between about 33.2 and $33.8 \mathrm{Ma}$ by ages on underlying sanidine-bearing lavas and overlying Bonanza Tuff. Compositionally similar dacite lavas, everywhere lacking sanidine, are widespread to the south and west in the San Juan Mountains. Thickness of individual dacite lavas, as much as $100 \mathrm{~m}$ fewer phenocrysts than the more widespread porphyritic dacite (unit Trd) of the Rawley complex; these are largely dacitic but likely include some silicic andesite $\left(60.5 \% \mathrm{SiO}_{2} ; 10-15 \% \mathrm{pl}>>\mathrm{hb}\right.$, cpx, bi). These lava types are only sparsely present in the Rawley complex but locally form thick lavas and rugged outcrops, especially along upper Indian Creek (LMNE, BZ) on the west flank of the Rawley accumulation. A large distinctive flow of fine-grained mafic dacite $\left(62.5 \% \mathrm{SiO}_{2} ; \sim 15 \%\right.$ phenocrysts and microphenocrysts, $\mathrm{pl}>>$ bi $>$ cpx, hbl) along Sawlog Creek (KM) is characterized by thick zones of complexly oriented columnar jointing and near-glassy groundmass textures suggestive of interaction with water in a paleovalley. Another thick flow of small-phenocryst dacite interfingers with andesite low in the volcanic sequence, on the south flank of the Rawley complex east of lower Findley Gulch (KM, SG). Some of the small-phenocryst dacite is texturally transitional to plagioclase andesite (unit Trap) but tends to form bold crumbly outcrops with large joint blocks and has more abundant biotite, typically a lighter-gray groundmass, and local flow layering. Thickness of individual lavas, as much as $100 \mathrm{~m}$

Trap Plagioclase andesite - Distinctive porphyritic dark-gray lavas $\left(56-60 \% \mathrm{SiO}_{2} ; 15-30 \% \mathrm{pl}>>\mathrm{cpx} \pm\right.$ sparse bi), characterized by tabular phenocrysts of plagioclase as much as $1 \mathrm{~cm}$ across. Most abundant at higher stratigraphic levels along the western caldera wall and slopes to the west and in upper parts of the caldera floor sequence, especially on upper slopes of Whale Hill. In places, too complexly intermixed with finer-grain andesite (unit Tra) to map separately, and some lavas and even individual outcrops display textural gradations between these two lava types. Where strongly propylitically or otherwise altered, difficult in places to distinguish from dacite (unit Trd). Maximum thickness, $>250 \mathrm{~m}$ on Whale Hill (WH) and northeast of upper Findley Gulch (KM)

Trax Andesite shatter breccia-Distinctive shattered andesite (photo 11), derived from the widespread andesite lavas (unit Tra). Well exposed discontinuously on each side of Kerber Creek up valley from junction with Little Kerber Creek and in Columbia Gulch (GG). Angular blocks mostly less than $1 \mathrm{~m}$ across are juxtaposed, with only minor matrix of pulverized andesite (photo 11.1, 11.2). In many exposures, finely shattered fragments of andesite fit together without large-scale rotation or other movement, and such rocks grade into less shattered andesite away from mapped ring faults. Although fault planes, slickensides, or other evidence of faulting are rare, these breccias are in close proximity to the main caldera-collapse ring fault that occupies the valley of Kerber Creek and are interpreted as highly shattered wall rocks, analogous in origin to that proposed for the shattered dacite lavas (unit Trdx) that occur adjacent to caldera ring faults in the same areas 
Andesite - Thick lavas of texturally diverse lava (photo 5.1), mostly finely porphyritic (pl $>\mathrm{cpx} \pm \mathrm{hbl} \pm$ sparse bi), constitute the volumetric bulk of the Rawley assemblage. With increase of phenocryst size, becomes gradational with plagioclase andesite (unit Trap). Some finely porphyritic lavas mapped with this unit have mafic dacite compositions, especially where biotite is present. Widely propylitically altered to dense greenish-gray rock along the west caldera wall and in the caldera-floor assemblage. Highly silicified and bleached locally within the caldera; in places difficult to distinguish from altered rhyolitic lavas (unit Trfr), especially on east flank of resurgent dome in proximity to the Turquoise Mine intrusion. Distinction from distal andesite (unit Tja) of Jacks Creek volcano is approximate and in places arbitrary along Middle Creek; distinction from andesite of Marshall caldera fill (unit Tma) similarly uncertain and arbitrary in places. On slopes east of upper Middle Creek, lavas mapped as andesite of the Rawley complex are nearly aphyric and slabby with abundant elongate vesicles, features which contrast with more finely porphyritic and massive andesite mapped as part of Marshall caldera fill (unit Tma) upvalley to the east. Groundmass ${ }^{40} \mathrm{Ar} /{ }^{39} \mathrm{Ar}$ age determinations on three samples from the Ute Pass area (KM) are in the range 33.26-33.45 Ma, shortly before eruption of the Bonanza Tuff. Maximum thickness, $>600 \mathrm{~m}$ on slopes of Saguache Peak (GG, KM)

Tras Andesite scoria - Float of weakly agglutinated reddish scoria and cinders of fine-grained andesite, on ridges north of Baxter Mountain (BZ) and northwest of Baxter Creek (CH); mark eruptive vents for some of the widespread lavas of this composition on the southwest flanks of the Rawley volcanic complex

\section{Rocks of the Marshall Caldera Cycle (33.8-33.9 Ma)}

At present levels of exposure, Marshall caldera, source of the Thorn Ranch Tuff, is defined largely by an arcuate unconformity along which ignimbrite $>400 \mathrm{~m}$ thick with no base exposed, megabreccia, and overlying lavas bank steeply against Proterozoic wall rocks (photo 7). The caldera-wall unconformity is especially well exposed at the geographic feature known as The Gate, in upper Silver Creek (photo 7.1B), and can be traced across Marshall Pass into upper Marshall Creek (MO). Marshall caldera is truncated to the southeast by collapse of the younger Bonanza caldera (photo $7.1 \mathrm{~A}$ ) and is largely concealed to the southwest beneath younger lavas of andesite, dacite, and local rhyolite that filled the collapse area to overflowing. Compositionally variable dacitic to rhyolitic ignimbrite within Marshall caldera has yielded ages and paleomagnetic directions indistinguishable from outflow Thorn Ranch Tuff far to the east, as documented by McIntosh and Chapin (2004). The Marshall cycle involved no resurgence, and its postcollapse lavas merge to the south and west with petrologically indistinguishable andesites and dacites of the Rawley volcanic complex, which are precursor to the Bonanza caldera cycle. The postcollapse lavas of the Marshall cycle also interfinger with the lake-bed deposits of the Pitch-Pinnacle Formation (Olson, 1983; Gregory and McIntosh, 1996), but this sedimentary assemblage is thickest beyond the northwest margin of Marshall caldera, in an embayment that appears to have been a broad paleovalley disrupted by caldera-forming events.

Postcollapse caldera-filling rocks - Thick petrographically diverse andesite to rhyolite lavas, interlayered lacustrine sediments, and local coarse volcaniclastic rocks that postdate eruption of the Thorn Ranch Tuff filled Marshall caldera and overflowed to the west (photo 7.3), where these rocks merge with undivided lavas of the Conejos Formation (Lipman, 2012). Most postcollapse lavas in Marshall caldera lack datable sanidine, but they are overlain by the Bonanza Tuff, thereby bracketing eruption of all these rocks between 33.12 and $33.9 \mathrm{Ma}$.

The postcollapse rocks project into a large embayment on the northwest side of the caldera between Marshall and Indian Creeks (PP) that may have originated as a large satellitic slump during caldera subsidence or, alternatively, could be a truncated pre-existing paleovalley. Caldera-filling lavas (units Tma, Tmap, Tmd) and interlayered lacustrine sedimentary rocks (unit Tmp) overlie scattered areas of poorly exposed Paleozoic formations and Badger Creek Tuff that may have slumped into the embayment during early caldera subsidence, but relations among these rocks in the embayment are obscured by large-scale Pleistocene slumping and landsliding (photo 7.3B). A remaining puzzle in this area is the apparent complete absence of proximal or intracaldera Thorn Ranch Tuff between Badger Creek Tuff and the postcaldera assemblage. Either the Indian Creek embayment stood topographically too high for the Thorn Ranch to accumulate there, or this ignimbrite was rapidly eroded and reworked into the tuffaceous sedimentary deposits of the Pitch-Pinnacle Formation (unit Tmp) shortly after eruption and caldera formation.

Some (perhaps much) andesite and dacite assigned to the Rawley volcanic complex (units Tra, Trd), which was precursor to development of the Bonanza caldera cycle, merge with the postcollapse lavas of Marshall caldera; petrologic and age relations are inadequate to reliably distinguish between these assemblages south of upper Middle Creek $(\mathrm{CH})$. Northwestern parts of the Rawley complex might equally well be interpreted as constituting postcollapse volcanism along the buried southeast margin of Marshall caldera 
Tmd Dacite lavas, undivided - Gray porphyritic flow-layered lava and breccia, characterized by light color and conspicuous biotite phenocrysts $\left(61.4-65.7 \% \mathrm{SiO}_{2} ; 20-30 \% \mathrm{pl}>>\mathrm{bi}, \mathrm{cpx}, \mathrm{hbl}\right.$; no sn). Massive, locally with flow layering or basal vitrophyre. Widespread upper lava unit, above thick andesite sequence and overlain by Bonanza Tuff along Continental Divide at head of Middle Creek and north side of Sargents Mesa (CH). The large dacite area north of Marshall Creek, although deposited directly on Badger Creek Tuff and on Paleozoic rocks, appears broadly correlative, based on age determinations $\left({ }^{40} \mathrm{Ar} /{ }^{39} \mathrm{Ar}\right.$ biotite plateaus, 33.45-33.60 Ma along Marshall Creek just west of map area) that are younger than Thorn Ranch Tuff. Maximum thickness, $>200 \mathrm{~m}$

Tmdf Small-phenocryst dacite - Light-gray dacite, containing 15-20\% small crystals (pl $>$ bi, cpx) along Continental Divide on west slope of Windy Peak $(\mathrm{CH})$. Other than smaller crystals, similar to overlying dacite (unit Tmd). Maximum thickness, $125 \mathrm{~m}$

Tmap Plagioclase andesite lavas-Distinctive porphyritic dark-gray lavas $\left(56-60 \% \mathrm{SiO}_{2} ; 15-25 \% \mathrm{pl}>>\mathrm{cpx}\right)$, characterized by tabular phenocrysts of plagioclase as much as $1 \mathrm{~cm}$ across

Tma Andesite lavas, undivided-Finely porphyritic to aphanitic dark-gray lavas and breccia (55-61\% $\mathrm{SiO}$; $5-15 \% \mathrm{pl}>\mathrm{cpx}, \mathrm{hbl}$ ), constituting the most voluminous lithology in the caldera-fill sequence. Individual flows are 5-20 m thick; multiple-flow accumulations are as much as several hundred meters thick

$\mathrm{Tmr}$

Rhyolite lava - Crystal-poor light-gray flow-layered and massive rhyolite lava and breccia (76.1\% $\mathrm{SiO}_{2} ; 1-3 \%$ phenocrysts of qtz, pl, bi), overlain by andesite (unit Tma) in lower Duncan Creek $(\mathrm{CH})$. Previously mapped as several small intrusions (Olson, 1983), but the rhyolite is vitrophyric along its upper contact zone, well flow layered, and disrupted into typical carapace breccia. Base of rhyolite in Duncan Creek not exposed; maximum thickness, $>100 \mathrm{~m}$

Tmds Sheep Mountain Dacite - Porphyritic gray to tan dacite $\left(65.2-67.0 \% \mathrm{SiO}_{2} ; 15-20 \% \mathrm{pl}>>\mathrm{sn}\right.$, bi), forming exceptionally large constructional volcanic dome centered on Sheep Mountain (BZ; photo 7.3A). Mostly massive, but flow layering present, especially near margins of dome. Extends at least onto slopes north of Silver Creek, where depositionally onlapped by andesitic lavas (unit Tma) and thin interbedded lacustrine sedimentary rocks (unit Tmp) of the Marshall caldera fill. Although previously interpreted as an intrusion on the Colorado State and Saguache County geologic maps (Tweto, 1979; Cappa and Wallace, 2007; Varga and Smith, 1984), this bulbous lava dome is in conformable stratigraphic sequence, between underlying Thorn Ranch Tuff (unit Ttr) and overlying andesite (unit Tma). Designated the Sheep Mountain Dacite by Lipman and others (2015). In most places, the feldspar is too argillized to date successfully, but an exceptionally fresh sample yielded $\mathrm{a}^{40} \mathrm{Ar} /{ }^{39} \mathrm{Ar}$ age $(\mathrm{sn})$ of $33.89 \pm 0.07 \mathrm{Ma}$, analytically indistinguishable from the mean age $(33.87 \mathrm{Ma})$ of the intracaldera Thorn Ranch Tuff. Maximum thickness, $>600 \mathrm{~m}$

Tmv Volcaniclastic rocks - Weakly indurated mudflow deposits, stream conglomerate, and tuffaceous sandstone that are poorly exposed in upper Middle Creek and along west margin of map area $(\mathrm{CH})$. Merge with undivided volcaniclastic rocks of the Conejos Formation to the west (Lipman, 2012). Thickness, 0-75 m

Tmp Pitch-Pinnacle Formation - Light-yellow-gray to tan finely laminated shale and well-bedded tuffaceous sandstone (PP, CH). Interlayered with andesitic and dacitic lavas within and adjacent to Marshall caldera. Abundant clay and altered rhyolitic ash in these deposits has caused widespread slumping of these deposits and interlayered lavas (photo 7.3B), limiting precision of map relations. Interpreted to represent shallow-water deltaic and lake deposits within the caldera moat and in broad paleovalley to northwest of the caldera margin, where not filled by rapidly deposited lavas. Sandstones and tuffaceous sediments have yielded ${ }^{40} \mathrm{Ar} /{ }^{39} \mathrm{Ar}$ ages (sn) ranging from $\sim 33.1 \mathrm{Ma}$ to $\sim 33.9 \mathrm{Ma}$ (McIntosh and Chapin, 2004), suggesting that basin-filling deposition, initiated after eruption of the Thorn Ranch Tuff, may have continued in upper parts of the sequence to the time of eruption of the Bonanza Tuff. Consistent with such an interpretation are sparse cobbles of Bonanza $\operatorname{Tuff}\left({ }^{40} \mathrm{Ar} /{ }^{39} \mathrm{Ar}\right.$ age, $\left.33.09 \pm 0.04 \mathrm{Ma}\right)$, which appear to have weathered out from high in the sediment sequence along the Pitch Mine road (PP). Thickness, 0-200 m

Thorn Ranch Tuff - Regional 33.9-Ma ignimbrite originally described and named by Epis and Chapin (1974), where preserved widely east of the upper Arkansas River valley segment of the Rio Grande rift. Within map area, welded fill within Marshall caldera is $>500 \mathrm{~m}$ thick along Silver and Starvation Creeks (BZ, MO) with no base exposed (photo 7.1B); it alternates between crystal-poor rhyolite $\left(73.1 \% \mathrm{SiO}_{2} ; 3-5 \% \mathrm{pl}, \mathrm{sn}>>\right.$ bi) and crystal-rich dacite $\left(66.2-69.0 \% \mathrm{SiO}_{2} ; 20-30 \% \mathrm{pl}>\mathrm{bi}, \mathrm{sn}, \mathrm{hb}\right)$, with ${ }^{40} \mathrm{Ar} /{ }^{39} \mathrm{Ar}$ ages (sn) of $33.91 \pm 0.09$ and $34.02 \pm 0.13 \mathrm{Ma}$. Lenses of intracaldera tuff interleaved with megabreccia in upper Marshall Creek (photo 7.2C) have been dated at 33.93-33.72 Ma (Gregory and McIntosh, 1996; McIntosh and Chapin, 2004). Small erosional remnants of proximal outflow crystal-rich dacite $\left(67.2-69.8 \% \mathrm{SiO}_{2} ; 20-30 \% \mathrm{pl}>\mathrm{bi}>\mathrm{sn}, \mathrm{hb}\right)$ in lower Cottonwood Creek (WH) and along Pagosa Creek (MO) are correlated with the intracaldera accumulation on basis of compositions and ${ }^{40} \mathrm{Ar} /{ }^{39} \mathrm{Ar}$ ages (sn) of $33.81 \pm 0.10$ and $34.09 \pm 0.11 \mathrm{Ma}$, respectively. 
In contrast, outflow Thorn Ranch Tuff, east of the Rio Grande rift, is described (Epis and Chapin, 1974; McIntosh and Chapin, 2004) as consisting entirely of phenocryst-poor rhyolite (where examined during this study, $74.8-76.9 \% \mathrm{SiO}_{2} ; 5-10 \% \mathrm{pl}, \mathrm{sn}>>$ bi), and has yielded ages (mean of five sites, $33.84 \mathrm{Ma}$ : McIntosh and Chapin, 2004) indistinguishable from the intracaldera and proximal outflow tuff within the map area. A weakly welded crystal-poor tuff, previously described as the East Gulch Tuff and interpreted as a separate underlying ignimbrite sheet (Epis and Chapin, 1974; McIntosh and Chapin, 2004) is now recognized as the less-welded lower part of the Thorn Ranch Tuff on the basis of similar composition, isotopic age (mean of three sites, 33.89 Ma), and gradational textural transition into overlying welded Thorn Ranch Tuff (Lipman and others, 2015). At least the bulk of this eastern distal Thorn Ranch is more silicic than the bulk of the intracaldera and small preserved remnants of proximal outflow tuff, a compositional relation similar to that observed for the Bonanza Tuff

Densely welded tuff-Tan to gray ignimbrite, exposed mainly as thick upper part of ponded deposit within the caldera, where no base is exposed. Fluidally welded with pumice flattening ratios as much as 100:1 and lineate locally (photo 7.2A), especially in proximity to steep caldera wall at The Gate (BZ). Contains abundant Precambrian lithic fragments (photo 7.2B), in contrast to other San Juan ignimbrites where Tertiary volcanic fragments are characteristic. Widely weakly propylitically altered

Ttrn Non-welded to partly welded tuff-Light-tan to gray ignimbrite, at top of intracaldera accumulation along Marshall Creek (PP) and as thin proximal outflow tuff in lower Cottonwood Creek (WH), where of sufficient size to map separately

Ttma Megabreccia, andesite clasts dominant—Poorly exposed mixed lithologies, in which andesitic blocks are abundant, on the ridge at headwaters of Marshall Creek (PP). Roadcut exposures on north side of ridge display large blocks of andesite and some Proterozoic rocks, in matrix of nonwelded tuff, alternating with lenses of glassy and devitrified densely welded Thorn Ranch Tuff, as previously mapped by Olson (1983) and interpreted as intracaldera deposits by T.A. Steven (written commun., 1986), Gregory and McIntosh (1996), and McIntosh and Chapin (2004)

Ttmb Megabreccia, clasts of Badger Creek Tuff-Small areas of slope debris dominated by blocks of Badger Creek Tuff, interpreted as landslide debris along the Indian Creek re-entrant or paleovalley on northwest side of Marshall caldera. Real outcrops are lacking. Additional areas mapped as semicoherent outcrops of Badger Creek Tuff along north side of Marshall Creek just east of the mouth of Indian Creek (PP) could alternatively be landslide megabreccia

Ttmc Megabreccia, Proterozoic clasts dominant-Poorly exposed mixed lithologies along the ridge at headwaters of Marshall Creek (PP: photo 7.2C). Little different from some parts of andesite-dominated megabreccia unit (unit Ttma), other than greater proportion of Proterozoic debris

\section{Sawatch Range Ignimbrite (Erupted from Aetna Caldera)}

Tbc Badger Creek Tuff-Distinctive gray partly to densely welded ignimbrite (67-69\% $\mathrm{SiO}_{2} ; 25-35 \% \mathrm{pl}>\mathrm{bi}>\mathrm{sn}$, $\mathrm{hb}, \mathrm{qtz}$ ). Well exposed along northwest margin of map area, west of Indian Creek and along lower Marshall Creek (PP). Even where exposed as rubble along lower Indian Creek, the tuff appears to be in place or nearly so, because it remains in coherent stratigraphic sequence, above rugged outcrops of Paleozoic strata and below lava fill of Marshall caldera. In a few places, Badger Creek rubble preserves a straightforward welding and density progression, increasing downward and suggestive of a primary depositional sequence. In contrast, some small poorly exposed areas of texturally heterogeneous Badger Creek Tuff farther east, along contacts between Tertiary and pre-Tertiary rocks, are likely fossil talus or breccia (unit Ttmb) that slumped down the northwest wall of Marshall caldera. Resembles Fish Canyon Tuff (unit Tfc) in lithology, mineral composition (for example, potassic sanidine: $\mathrm{Or}_{72} \mathrm{Ab}_{25} \mathrm{An}_{0.8} \mathrm{Cn}_{2.8}$ ), and rock chemistry, but erupted at 34.1 Ma (McIntosh and Chapin, 2004; Zimmerer and McIntosh, 2012b) from Aetna caldera in the Sawatch Range (fig. 1). Where in close proximity to the Fish Canyon Tuff along Marshall Creek, the Badger Creek is characterized by more abundant lithic fragments and larger pumice lenses that are more glassy. Thickness, $0-40 \mathrm{~m}$

\section{Conejos Formation, Lower Units}

Lavas and proximal breccias that are interpreted to have been emplaced prior to eruption of the Thorn Ranch Tuff at 33.9 Ma are grouped as lower units of the overall Conejos Formation. These include andesite along Poncha Creek (MO, PO), where small erosional remnants of Thorn Ranch Tuff provide direct stratigraphic control for parts of the lava assemblage, and the large Jacks Creek volcano to the southwest, where isotopic ages indicate emplacement prior to eruption of the Thorn Ranch Tuff. The lower units of the Conejos Formation in the Bonanza region appear to be largely or entirely older than basal volcanic deposits farther south and west in the San Juan region. 
Early lavas and proximal breccias - Lavas and flow breccias of aphanitic to porphyritic lava in northern parts of the map area that cannot readily be related to individual volcanic centers such as those identified to the south; much or all of this assemblage appears to predate eruption of the Thorn Ranch Tuff at 33.9 Ma

Tcd Dacite - Gray porphyritic flow-layered lava and breccia, characterized by light color and conspicuous biotite phenocrysts $\left(62-68 \% \mathrm{SiO}_{2} ; 20-30 \% \mathrm{pl}>>\mathrm{bi}, \mathrm{cpx}, \mathrm{hbl}\right)$. Massive, locally with flow layering or basal vitrophyre. Crops out as large rounded granitoid-like boulders. Less abundant than andesite of Conejos Formation, which it commonly overlies. A biotite plateau age for dacite along Poncha Creek (MO), at $35.04 \pm 0.11 \mathrm{Ma}$, is the oldest dated sample from the map area. A nearby dacite exposure, along the Marshall Pass road, yielded a biotite plateau age of 33.46 \pm 0.11 Ma that may be too young. Maximum exposed thickness, $>140 \mathrm{~m}$

Tcap Plagioclase andesite-Distinctive porphyritic dark-gray lavas $\left(56-60 \% \mathrm{SiO}_{2} ; 15-30 \% \mathrm{pl}>>\mathrm{cpx}\right)$, characterized by tabular phenocrysts of plagioclase as much as $1 \mathrm{~cm}$ across. In addition to less biotite, is distinguished from dacite in the area by common vesicular textures and smaller angular joint fragments. A groundmass age of $32.49 \pm 0.05$ Ma for a flow along Poncha Creek (MO) is too young; this flow is overlain by dacite dated at 35.04 Ma and then by Thorn Ranch Tuff (33.9 Ma). Maximum exposed thickness, $>200 \mathrm{~m}$

Tca Andesite - Finely porphyritic to aphanitic dark-gray lavas and breccia (55-61\% $\left.\mathrm{SiO}_{2} ; 5-15 \% \mathrm{pl}>\mathrm{cpx}, \mathrm{hbl}\right)$, constituting the most voluminous lithology of the Conejos Formation. Individual lavas are 5-40 m thick

Tcab

Andesite breccia-Massive breccia of fine-grained andesite and some intermixed plagioclase andesite and dacite, locally forming rugged outcrops along Poncha Creek (MO). Probably represents proximal cone deposits on flank of a central volcano. Maximum thickness, $>120 \mathrm{~m}$

Tcv Volcaniclastic rocks - Reworked crudely bedded to well-bedded conglomerates, sandstones, and mudflow breccias, containing clasts of dark andesite and dacite in light-gray sandy matrix. Primary dips are typically $<5^{\circ}$. Mainly distal weakly indurated deposits on lower slopes of volcanic constructs; most abundant along Poncha Creek and farther northeast (MO). In places, poorly indurated laharic deposits containing lithologically diverse rounded clasts can be difficult to distinguish from andesitic facies of the much younger volcaniclastic rocks of the Dry Union Formation (unit Tdua), especially along ridges followed by the Rainbow Trail northwest of Poncha Pass (PO). Distinction is further complicated by local presence of sparse Precambrian cobbles in volcaniclastic units (unit Tcv) that are interlayered with the andesitic lavas (unit Tca), well exposed east of O'Haver Lake (MO). The volcaniclastic unit is less widespread than elsewhere in the San Juan region, because proximal lavas are dominant in the early Conejos assemblage of the Bonanza region. Maximum thickness, about $100 \mathrm{~m}$ north of Poncha Creek

\section{Jacks Creek Volcano ( 34.5 Ma)}

Jacks Creek is a symmetrical central volcano (photo 4), about $10 \mathrm{~km}$ in diameter at present-day outcrop level, consisting mainly of outward-dipping andesitic lavas and breccia (photo 4.1) that overlie rhyolite near the volcano core. Lavas of fine-grained biotite dacite are discontinuously present along the volcano flanks. Low elevations and limited vegetative cover on south-facing slopes provide exceptional exposures, in comparison to precaldera rocks in other parts of the map area. Radial dikes are well exposed on its south and east flanks (photos 4.2, 4.3; dike compositions range from andesite to low-silica rhyolite, including a large dike of porphyritic low-silica rhyolite that has yielded a ${ }^{40} \mathrm{Ar} /{ }^{39} \mathrm{Ar}$ age (sn) of $34.21 \pm 0.10 \mathrm{Ma}$. A central intrusion of similar porphyry (photo 4.4) has a similar ${ }^{40} \mathrm{Ar} /{ }^{39} \mathrm{Ar}$ age (sn) of $34.29 \pm 0.06 \mathrm{Ma}$. An adjacent core intrusion is fine-grained granodiorite that grades into aphanitic andesite. Attempts to obtain groundmass ages from sanidine-free lavas and dikes of intermediate composition have yielded somewhat inconsistent results, but most are in the range 34.1-34.5 Ma (table 6). Groundmass from the basal rhyolite flow yielded complex age spectra: $34.16 \pm 0.22 \mathrm{Ma}$ (integrated) and $35.36 \pm 0.11 \mathrm{Ma}$ (isochron).

Jacks Creek thus appears to be the oldest volcanic center within the map area, predating eruption of the Thorn Ranch Tuff from Marshall caldera. The north flank of the Jacks Creek edifice banks against paleohills of Precambrian rocks and is onlapped by younger intermediate-composition lavas that appear to fill southern parts of Marshall caldera. Axial parts of the Jacks Creek volcano were eroded to levels that expose the central intrusions, within an interval of about $1.5 \mathrm{~m}$.y. prior to eruption of the Bonanza Tuff, which laps onto the core of this volcano.

Intrusions - Fine-grained rocks, mostly dikes radial to a central intrusive complex of porphyritic rhyolite and fine-grained granodiorite

Tjir Rhyolite - Light-gray to tan dikes $(\sim 5 \% \mathrm{pl}>\mathrm{bi}$, qtz) and a central body of more coarsely porphyritic rhyolite and silicic dacite $\left(68.3-71.4 \% \mathrm{SiO}_{2} ; \sim 10 \% \mathrm{sn}, \mathrm{pl}\right.$, qtz>> bi), in which the plagioclase, biotite, and groundmass are highly altered. Parts of the central body are pyroclastic breccia, perhaps constituting vent fill (photo 4.4)

Tjid Dacite - Gray dikes and larger intrusive bodies: some phenocryst rich, containing $15-30 \% \mathrm{pl}>>\mathrm{bi}>\mathrm{hbl}$, cpx; others of more mafic dacite containing $5-10 \%$ pl $>>$ bi (photos $4.2,4.3$ ) 
Tjia Andesite - Dark-gray dikes and other small intrusive bodies, typically containing only small phenocrysts (pl>cpx, hbl)

Tjig Granodiorite - Fine-grained equigranular granodiorite $\left(60 \% \mathrm{SiO}_{2} ; \mathrm{pl}>>\mathrm{cpx}>>\right.$ bi), grading irregularly into porphyritic andesite; forms arcuate body around north and east side of central intrusion of porphyritic rhyolite (unit Tjir)

Lavas and related rocks-Mostly dark sparsely porphyritic lavas and interleaved volcaniclastic rocks defining outward-dipping flanks of a central cone

Tjd Dacite - Only a few scattered small remnants of typical porphyritic dacite have been mapped on northeast flanks of the Jacks Creek volcano (LMNE); these may alternatively be distal southeast lavas of the Rawley volcano (unit Trd)

Tjds, Tjdb Small-phenocryst dacite - Several petrographically distinct areas of sparsely porphyritic or fine-grained light-gray dacite. A thick lava containing about $10 \%$ bronzy biotite and small plagioclase, with slabby jointing parallel to flow layers, is overlain by plagioclase andesite of Jacks Creek type along lower Bear Creek (LMNE). This distinctive dacite lava, which is petrologically similar to the large flows of small-phenocryst dacite on the east flank of Tracy Volcano (unit Tyds), was erupted from a local vent at hill 8866 ' just north of the mouth of Bear Creek, marked by agglutinated spatter, breccia, and steep flow layering (unit Tjdb). Alternatively, this may be a younger lava (unit Tmdf), forming southern fill of Marshall caldera. Other areas of fine-grained dacite, containing $10-15 \%$ small phenocrysts (pl, bi, hbl), cap the ridge between lower Cabin Draw and Middle Creek and farther southeast between Middle and Ford Creeks (LMNE). A small area of light-gray crystal-poor flow-laminated lava and flow breccia ( $\sim 3 \% \mathrm{pl}>>$ bi), capping a ridge east of Bear Creek (LMNE), appeared rhyolitic from megascopic appearance, but it compositionally is small-phenocryst dacite $\left(66.7 \% \mathrm{SiO}_{2}\right)$

Tjap Plagioclase andesite-Distinctive porphyritic dark-gray lavas $\left(56-60 \% \mathrm{SiO}_{2} ; 15-30 \% \mathrm{pl}>>\mathrm{cpx}\right)$, characterized by tabular phenocrysts of plagioclase as much as $1 \mathrm{~cm}$ across. Only one small area mapped, where appears to overlie rhyolite (unit Tjfr) near the volcano core, south of Jacks Creek (LMNE)

Tja Andesite - Finely porphyritic to aphanitic dark-gray lavas and breccia (55-61\% $\mathrm{SiO}_{2} ; 5-15 \% \mathrm{pl}>\mathrm{cpx}$, $\mathrm{hbl}$ ), constituting the most voluminous lithology of the volcano. Individual lavas are 5-20 m thick; multiple-flow accumulations are as much as several hundred meters thick; commonly interlayed with laharic volcaniclastic breccias containing clasts of andesite (photo 4.1)

Tjab Andesite cone breccia-Thick sequence of crudely stratified massive breccia along Cross Creek on northwest flank of volcano (LMNE), typically containing angular clasts of fine-grained andesite $5-25 \mathrm{~cm}$ in diameter in a microbreccia matrix of similar composition. In places, interfingers with more coherent flows of andesite, as lower and upper breccias of a'a-type lavas; probably also includes proximal deposits of Strombolian-type explosive eruptions on flank of cone

Tjfr Rhyolite - Light-tan to gray crystal-poor lava (3-5\% pl $>>$ bi) at lowest exposed levels near central intrusion of Jacks Creek volcano. Flow layering widely well developed. Where silicified and otherwise variably altered, makes rugged outcrops; elsewhere exposed mainly as chippy light-colored float. Exposed thickness, to $100 \mathrm{~m}$

Tjv Volcaniclastic rocks - Crudely bedded breccias, mainly of laharic origin, contain abundant andesitic clasts, are weakly indurated, and tend to form slopes between interlayered lavas that crop out more conspicuously. These have not been mapped in detail, but probably constitute about half the volume of the volcano at exposed levels

\section{PREVOLCANIC ROCKS}

Paleozoic and rare lower-Tertiary sedimentary deposits are widely distributed along margins of the map area, beneath the Oligocene volcanic rocks of the San Juan region; large areas are concealed beneath widespread landslide deposits, especially along Marshall Creek (PP, CH). The Paleozoic sedimentary sequence is underlain by Proterozic granodiorite that intrudes metasedimentary and metavolcanic rocks.

\section{LOWER TERTIARY SEDIMENTARY ROCKS}

Tev Conglomerate and sandstone (Eocene?) - Poorly consolidated prevolcanic and early volcanic sedimentary rocks in paleovalleys. Conglomerate, containing boulders of Precambrian rocks to $>1 \mathrm{~m}$, mixed with smaller volcanic clasts, is exposed locally along the north side of Poncha Creek (PO) between exposed Precambrian rocks and overlying andesite lavas. This seemingly nonindurated conglomerate resembles volcaniclastic rocks of the Conejos Formation (unit Tcv) that locally contain Precambrian cobbles and also andesitic facies of the Dry Union Formation (unit Tdua) in nearby areas, but it differs by having much larger boulders of Precambrian rocks. Poorly exposed loose cobbles and boulders of Precambrian crystalline rocks (clasts to $1 \mathrm{~m}$ ) mark a second area of this deposit 
along contacts between volcanic and underlying pre-Tertiary rocks, between the Chester townsite and Indian Creek (PP). Records erosion from paleohills of Precambrian rocks prior to Tertiary volcanism. Absence of volcanic clasts argues against alternative interpretation of slope wash down north margins of Marshall caldera. The coarse boulders in these local deposits, along with absence of early Tertiary sedimentary deposits along the unconformity at the base of the volcanic sequence elsewhere in the map area, provide evidence that much of the prevolcanic paleosurface stood topographically high and was primarily a region of erosion rather than deposition. Thickness variable, most probably $<30 \mathrm{~m}$

\section{PALEOZOIC SEDIMENTARY ROCKS}

Paleozoic strata are exposed along both sides of lower Kerber Creek (GG, VG), where they have been described by Burbank (1932), along Indian and Marshall Creeks (PP) in the northwest corner of the map area (Olson, 1983), and in upper Poncha Creek (MO). The upper Paleozoic rocks (photo 3.3) are terrestrial clastic rocks derived from Precambrian basement that was exposed during uplift of the Ancestral Rocky Mountains in the Pennsylvanian. These rocks unconformably overlie lower Paleozoic strata, which are dominated by marine carbonate deposition (photo 3.2). A south-plunging anticline defined by the well-exposed Paleozoic sequence along lower Kerber Creek and cored by Precambrian granodiorite, previously interpreted as a prevolcanic structure (Burbank, 1932), is here reinterpreted as the south flank of an elongate postcollapse resurgent dome within Bonanza caldera because volcanic rocks are tilted along with the underlying Paleozoic strata. The Paleozoic strata are particularly helpful for interpreting the resurgence of Bonanza caldera because they provide far more stratigraphic resolution than the overlying volcanic units.

North of Marshall Creek and in Indian Creek (PP), the Paleozoic rocks form a well-exposed coherent stratigraphic sequence that dips broadly southward, with several south-plunging prevolcanic folds adjacent to the Chester fault (Olson, 1988; Nash, 1988). South of Marshall Creek (CH), these formations are discontinuously exposed beneath widespread cover of Quaternary landslides and slumps, but upper Paleozoic strata are dominant, consistent with the southward regional dip. The best exposed areas are lithologically coherent and are interpreted as largely in place, flooring a shallow embayment along the northwest margin of Marshall caldera, rather than debris slides into a deep volcanic depression. Upper Paleozoic terrestrial strata terminate abruptly against Precambrian granodiorite to the south, probably along a north-dipping east-west fault of uncertain age, although poor exposures could permit alternative interpretations. The Paleozoic rocks south of Marshall Creek are not a simple coherent stratigraphic sequence, but the limited area of exposure and sparse outcrops make it uncertain whether the complexities are due to prevolcanic faulting or related to slumping at the west margin of Marshall caldera.

In upper Poncha Creek, small areas of steeply-dipping lower Paleozoic strata are repeated along north-northwesttrending faults of uncertain age.

Upper Paleozoic sedimentary rocks - Terrestrial clastic rocks derived mainly from the Precambrian basement, after uplift of the Ancestral Rocky Mountains

Ps Sharpsdale Formation (Pennsylvanian) - Thickly bedded sequence of grayish-red to purplish sandstone, siltstone, shale, and local pebbly conglomerate (photos 3.3B,C). Overlies the Kerber Formation gradationally, as marked by increasing proportions of fine-grained sediments and increasing abundance of detrital mica. In the Marshall Creek area, light-gray chippy limestone, seen only as float, is locally intermixed with the sandy sediments. Various names have been applied to this assemblage, including Maroon Formation by Burbank (1932) along lower Kerber Creek, Belden Formation by Olson (1983) in Indian and Marshall Creeks, and Minturn Formation in the Sangre de Cristo Range to the east (Lindsey and others, 1985). Rocks in the map area are tentatively assigned to the Sharpsdale Formation, in accord with the regional review by Cappa and Wallace (2007). Upper parts of this unit in the map area may be correlative with the Minturn Formation as mapped in the Sangre de Cristo Range (Lindsey and others, 1985), but this study was inadequate to evaluate this alternative. Thickness at least $500 \mathrm{~m}$, perhaps $>1,000 \mathrm{~m}$ (Burbank, 1932), but poor exposures and possible fault repetitions may have led to an overestimate of thickness

Pk Kerber Formation (Pennsylvanian) - Light-gray to tan coarsely granular massive quartz sandstone and quartz-rich arkose, sparse shale interbeds, and local pebbly conglomerate of Precambrian provenance (photo 3.3A). Locally forms bold outcrops. Overlies lower Paleozoic rocks unconformably; in places, as Limekiln Spring (GG), deposited directly on Precambrian granodiorite. Grades upward into Sharpsdale Formation, as proportions of silt and shale interbeds increase, along with increased presence of mica and feldspar in sandstones. Named by Burbank (1932) without specifying a type area, but especially thick and well exposed north of Kerber Creek and east of Cody Gulch (GG), where thickness probably exceeds $200 \mathrm{~m}$. Similar sandstone was mapped as lower member of the Belden Formation in the Marshall Creek area by Olson (1983). Thickness, 50-200 m 
MI Leadville Limestone (Mississippian)-Massive blue-gray to brownish limestone and dolomite. More thinly bedded in lower and upper parts. Thickness, 50-100 m

Mlb Brecciated and silicified rocks-Local dark-gray to black zones of intensely brecciated silicified rock that grade laterally into typical carbonate facies of the formation. Silicification is clearly secondary, unrelated to depositional or penecontemporaneous processes (Banks, 1970). Location of prominent cliff-forming exposures at mouths of Soda Spring and Cody Gulch (GG) suggests possible origin related to southern caldera ring fault concealed along Kerber Creek. Thickness, 0-20 m

Dc Chaffee Group (Devonian and lower Mississipian) - Includes Parting Formation and Dyer Dolomite, undivided. The Parting Formation consists of finely bedded light-brown to tan quartz sandstone and interfingering gray calcareous beds that are discontinuously exposed; thickness is 5-10 m. Overlying Dyler Dolomite is more uniform yellowish-tan bedded carbonate rock that rarely makes outcrops and typically weathers to small chips. Thickness, 25-40 m

Of Fremont Dolomite (Upper Ordovician) - Cliff-forming light-gray limestone and dolomite. Massive and weakly bedded, becoming more shaley near top. Upper limestone member of the Tomichi Formation of Burbank (1932). Thickness, 75-100 m

Oh

Harding Quartzite (Middle Ordovician) - Dense well-cemented gray quartz sandstone that weathers iron-stained light brown or reddish brown. Resistant to weathering, and forms rugged outcrops and widely distributed downslope talus. Quartzite member of the Tomichi Formation of Burbank (1932). Thickness, 10-25 m

Om

Manitou Limestone (Lower Ordovician) — Cliff-forming gray limestone and dolomite that weathers tan to light brown (photo 3.2D), with 2- to 5 -cm beds of white chert in lower part. Lower limestone member of the Tomichi Formation of Burbank (1932). Directly overlies Precambrian granodiorite and metamorphic rocks, becoming more massive upward. Nowhere in the map area were there exposures of basal Sawatch Quartzite (Cambrian) between the Manitou and underlying Precambrian rocks of sufficient size to show on the geologic map, but scattered float of quartzite is present along this contact near a residential driveway south of Cody Gulch (GG, lat 38 $13.96^{\prime}$ N., long $106^{\circ} 2.70^{\prime}$ W.). Thickness, 30-50 m

Pl Lower Paleozoic rocks, undivided-Small areas of poorly exposed carbonate rocks, mainly along Marshall Creek (CC), that could not be confidently assigned to individual formations

\section{PRECAMBRIAN ROCKS}

Precambrian rocks in the map area consist largely of texturally and compositionally variable granitoid rocks, intrusive into diverse metasedimentary and metavolcanic country rocks (photo 3.1). These units have not been subdivided in detail on this map, where they mainly have been studied for stratigraphic and structural influences on emplacement of the volcanic deposits. The Precambrian rocks define a surface of rugged paleorelief beneath the Tertiary volcanic cover, with paleohills of basement lithologies that crop out irregularly and unexpectedly. Exposures of Precambrian rocks define much of the north and south margins of Bonanza caldera and the northeast rim of Marshall caldera. Precambrian rocks are also exposed deep beneath the volcanic sequence within Bonanza caldera, along the south-plunging crest of the resurgent dome in Cody and Sand Gulches (GG) and along the northeast flank in Alder Creek (WH). Paleohills exposing granitic rocks (unit $p € g$ ), which make an east-west belt from beneath the north flank of Jacks Creek volcano (LMNE) eastward into the head of Mill Gulch (KM), may roughly delimit the largely buried south rim of Marshall caldera (fig. 11).

p€a Aplite of Alder Creek-Distinctive sugary-textured white to tan aplite, consisting mainly of mosaic of quartz and K-feldspar (microcline in some samples, microperthite in others), accompanied by sparse biotite. Foliation or other structural fabric weakly developed to absent. In places, deceptively resembles aplitic granite of the Tertiary Spring Creek intrusion (unit Tsa) that occupies next drainage to south. Distinction between these aplitic rocks of greatly different ages was initially further confused by widespread acid-sulfate alteration of Tertiary volcanic rocks where adjacent to the aplite of Alder Creek; pyritic mineralization appears to have been localized along the unconformity at the base of the Tertiary rocks. Proterozoic age is inferred from presence of microcline, distinct mineral foliation in places, and local gradations into coarser granitic rocks

pfg Granitoid intrusive rocks, undivided-Medium-grained pink to tan, locally weakly gneissic Proterozoic intrusive rock (photo 3.1A), containing about 30-40\% microcline, 25\% plagioclase, 20-30\% quartz, and 3-10\% biotite. In upper Marshall Creek, mapped and described in more detail by Olson (1988). Published U-Pb zircon ages in nearby areas are about 1,700 Ma (Bickford and others, 1989)

p€m Metamorphic rocks, undivided-Interlayered metasedimentary and metavolcanic Proterozoic rocks (photo $3.1 B$ ), including foliated schist, phyllite, quartzite, meta-arkose, metabasalt, and metarhyolite. 
Fine-grained tan meta-arkose is widespread along east Marshall Pass road and adjacent slopes west of O’Haver Lake (MO). Mapped in upper Marshall Creek and described in more detail by Olson (1988) and references therein

peu Precambrian crystalline rocks, undivided-Granitoid and metamorphic rocks along north margin of map area that have not been mapped or subdivided systematically

\section{References Cited}

Acocella, V., 2007, Understanding caldera structure and development; an overview of analogue models compared to natural calderas: Earth Science Reviews, v. 85, p. 125-160.

Askren, D.R., Whitney, J.A., and Roden, M.F., 1991, Petrology and geochemistry of the Huerto Andesite, San Juan volcanic field, Colorado: Contributions to Mineralogy and Petrology, v. 107 , p. 373-386.

Bachmann, Olivier, Deering, C.D., Lipman, P.W., and Plummer, C., 2014, Building zoned ignimbrites and recycling silicic cumulates; insight from the 1,000 $\mathrm{km}^{3}$ Carpenter Ridge Tuff, Colorado: Contributions to Mineralogy and Petrology, article 1025.

Bachmann, Olivier, Dungan, M.A., and Lipman, P.W., 2002, The Fish Canyon magma body, San Juan volcanic field, Colorado-Rejuvenation and eruption of an upper crustal batholithic magma chamber: Journal of Petrology, v. 43, p. 1469-1503.

Bachmann, Olivier, Oberli, F., Dungan, M.A., and Fischer, H., $2007,{ }^{40} \mathrm{Ar} /{ }^{39} \mathrm{Ar}$ and U-Pb dating of the Fish Canyon magmatic system, San Juan volcanic field, Colorado; evidence of an extended crystallization history: Chemical Geology, v. 236, p. 134-166.

Bailey, R.A., Dalyrymple, G.B., and Lanphere, M.A., 1976, Volcanism, structure, and geochronology of Long Valley caldera, Mono County, California: Journal of Geophysical Research, v. 81, p. 725-744.

Banks, N.G., 1970, Nature and origin of early and late cherts in the Leadville Limestone, Colorado: Geological Society of America Bulletin, v. 81, p. 3033-3048.

Best, M.G., Christiansen, E.H., Deino, A.L., Gromme, S., Hart, G.L., and Tingey, D.L., 2013, The 36-18 Ma Indian PeakCaliente ignimbrite field and calderas, southeastern Great Basin, USA-Multicyclic super-eruptions: Geosphere, v. 9, p. 864-950.

Bethke, P.M., 2011, Mineralization in the eastern San Juan Mountains, in Blair, R., and Bracksiek, G., eds., The eastern San Juan Mountains - Geology, ecology, and human history: The University Press of Colorado, p. 39-60.

Bickford, M.E., Shuster, R.D., and Boardman, S.J., 1989, U-Pb geochronology of the Proterozoic volcano-plutonic terrane in the Gunnison and Salida areas, Colorado: Geological Society of America Special Paper 235, p. 33-48.

Bove, D.J., Hon, Ken, Budding, K.E., Slack, J.F., Snee, L.W., and Yeoman, R.A., 2001, Geochronology and geology of late Oligocene through Miocene volcanism and mineralization in the western San Juan Mountains, Colorado: U.S. Geological Survey Professional Paper 1642, 30 p.
Branney, M.J., and Kokelaar, P., 1994, Volcanotectonic faulting, soft-state deformation, and rheomorphism of tuffs during development of a piecemeal caldera, English Lake District: Geological Society of America Bulletin, v. 106, p. 507-530.

Bridwell, R.J., 1968, Geology of the Kerber Creek area, Saguache County, Colorado: Golden, Colo., Colorado School of Mines, M.S. thesis, 104 p.

Brister, B.S., and Gries, R.R., 1994, Depth and geometry of the northern Rio Grande rift in the San Luis Basin, south-central Colorado, in Keller, G.R., and Cather, S.M., eds., Basins of the Rio Grande rift - Structure, stratigraphy, and tectonic setting: Geological Society of America Special Paper 291, p. 39-58.

Bruns, D.L., Epis, R.C., Weimer, R.J., and Steven, T.A., 1971, Stratigraphic relations between Bonanza center and adjacent parts of the San Juan volcanic field, south-central Colorado, in James, H.L., ed., San Luis Basin: New Mexico Geological Society, Guidebook 22, p. 183-190.

Burbank, W., 1932, Geology and ore deposits of the Bonanza mining district: U.S. Geological Survey Professional Paper 169, 166 p.

Byers, F.S., Jr., Carr, W.J., Christiansen, R.L., Lipman, P.W., Orkild, P.P., and Quinlivan, W.D., 1976, Geologic map of the Timber Mountain caldera area, Nye County, Nevada: U.S. Geological Survey Miscellaneous Investigations Series Map I-891, scale 1:48,000.

Caine, J.S., Bruhn, R.L, and Forster, C.B., 2010, Internal structure, fault rocks, and inferences regarding deformation, fluid flow, and mineralization in the seismogenic Stillwater normal fault, Dixie Valley, Nevada: Journal of Structural Geology, v. 32, p. 1576-1589.

Cappa, J.A., and Wallace, C.A., 2007, Geology and mineral resources of Saguache County, Colorado: Colorado Geological Survey Resource Series 44, CGS RS 44 (CD-ROM).

Cashman, K.V., and Giordano, G., 2014, Calderas and magma reservoirs: Journal of Volcanology and Geothermal Research, v. 288 , p. $28-45$.

Chapin, C.E., and Cather, S.M., 1994, Tectonic setting of the axial basins of the northern and central Rio Grande rift, in Keller, G.R., and Cather, S.M., eds., Basins of the Rio Grande rift - structure, stratigraphy, and tectonic setting: Geological Society of America, Special Paper 291, p. 5-26.

Chapin, C.E., and Epis, R.C., 1964, Some stratigraphic and structural features of the Thirtynine Mile volcanic field, central Colorado: Mountain Geologist, v. 1, no. 3, p. 145-160.

Chapin, C.E., and Lowell, G.R., 1979, Primary and secondary flow structures in ash-flow tuffs of the Gribbles Run 
paleovalley, central Colorado: Geological Society of America Special Paper 180, p. 137-153.

Christiansen, R.L., and Miller, C.D., 1989, Mount Shasta and vicinity: New Mexico Bureau of Mines and Mineral Resources Memoir 47, p. 216-223.

Cole, J.W., Milner, D.M., and Spinks, K.D., 2005, Calderas and caldera structures; a review: Earth Science Reviews, v. 69, p. $1-96$.

Colucci, M.T., Dungan, M.T., Ferguson, K.M., Lipman, P.W., and Moorbath, Steven, 1991, Precaldera lavas of the southeast San Juan volcanic field-Parent magmas and crustal interactions: Journal of Geophysical Research, v. 96, p. 13412-13434.

Cook, D.R., 1960, Bonanza project, Bear Creek Mining Company: American Institute of Mining, Metallurgy, and Petroleum Engineers Transactions, v. 217, p. 285-295.

Cross, Whitman, and Larsen, E.S., Jr., 1935, A brief review of the geology of the San Juan region of southwestern Colorado: U.S. Geological Survey Bulletin 843, 138 p.

De Silva, S.L., Mucek, A.E., and Gregg, P.M., 2015, Resurgent Toba - field, chronologic, and model constraints on time scale and mechanism of resurgence at large calderas: Frontiers in Earth Science, http://dx.doi.org/10.3389/feart.2015.00025.

Diehl, J.F., Lipman, P.W., and Beck, M.E., Jr., 1974, Paleomagnetism and magnetic polarity zonation in some Oligocene volcanic rocks from the San Juan Mountains, Colorado: Journal of Geophysics, v. 37, p. 323-332.

Drenth, B.J., Keller, G.R., and Thompson, R.A., 2012, Geophysical study of the San Juan batholith complex, southwestern Colorado: Geosphere, v. 8, p. 669-684.

Dungan, M.A., Lipman P.W., Colucci, M.T., Ferguson, K.M., and Balsley, S.D., 1989, Southeastern (Platoro) caldera complex, in Chapin, C.E., and Zidek, J., eds., Field excursions to volcanic terranes in the western United States, Volume I-Southern Rocky Mountain region: New Mexico Bureau of Mines and Mineral Resources Memoir 46, p. 305-329.

Epis, R.C., and Chapin, C.E., 1968, Geologic history of the Thirtynine Mile volcanic field, central Colorado, in Epis, R.C., ed., Cenozoic volcanism in the Southern Rocky Mountains: Colorado School of Mines Quarterly, v. 63, no. 3, p. 51-85.

Epis, R.C., and Chapin, C.E., 1974, Stratigraphic nomenclature of the Thirtynine Mile volcanic field: U.S. Geological Survey Bulletin 1395-C, 23 p.

Epis, R.C., Wobus, R.A., and Scott, G.R., 1979, Geologic map of the Black Mountain quadrangle, Fremont and Park Counties, Colorado: U.S. Geological Survey Miscellaneous Investigations Map I-1195, scale 1:62,500.

Fleck, R.J., Sutter, J.F., and Elliot, D.H., 1977, Interpretation of discordant ${ }^{40} \mathrm{Ar} /{ }^{39} \mathrm{Ar}$ age-spectra of Mesozoic tholeiites from Antarctica: Geochimica et Cosmochimica Acta, v. 41, p. $15-32$.

Folkes, C.B., de Silva, S.L., Schmitt, A.K., and Cas, R.A.F., 2011, A reconnaissance of the U-Pb zircon ages in the Cerro Galan system, northwestern Argentina: Journal of Volcanology and Geothermal Research, v. 206, p. 136-147.

Foster, D.A., Harrison, T.M., Copeland, P., and Heizler, M.T., 1990, Effects of excess argon within large diffusion domains on K-feldspar age: Geochimica et Cosmochimica Acta, v. 54, p. 1699-1708.

Fridrich, C.J., DeWitt, E., Bryant, B., Richard, S., and Smith, R.P., 1998, Geologic map of the Collegiate Peaks Wilderness area and the Grizzly Peak caldera, Sawatch Range, central Colorado: U.S. Geological Survey Miscellaneous Investigations Map I-2565.

Fridrich, C.J., and Mahood, G.A., 1987, Compositional layers in the zoned magma chamber of the Grizzly Peak Tuff: Geology, v. 15, p. 299-303.

Gregg, P.M., de Sliva, S.L., Grosfils, E.B., and Parmigiani, J.P., 2012, Catastrophic caldera-forming eruptions; thermomechanics and implications for eruption triggering and maximum caldera dimensions on Earth: Journal of Volcanology and Geothermal Research, v. 241-242, p. 1-12.

Gregory, K.M., and McIntosh, W.C., 1996, Paleoclimate and paleo-elevation of the Oligocene Pitch-Pinnacle flora, Sawatch Range, Colorado: Geological Society of America Bulletin, v. 108, p. 545-561.

Gries, R.R., 1985, San Juan sag-Cretaceous rocks in a volcanic-covered basin, south-central Colorado: The Mountain Geologist, v. 22, p. 167-179.

Gudmundsson, A., 2008, Magma-chamber geometry, fluid transport, local stresses and rock behaviour during collapse caldera formation: Developments in Volcanology, v. 10, p. 313-349.

Harrison, T.M., Heizler, M.T., Lovera, O.M., Wenji, C., and Grove, M., 1994, A chlorine disinfectant for excess argon released from K-feldspar during step heating: Earth and Planetary Science Letters, v. 12, p. 95-104.

Henry, C.D., 2008, Ash-flow tuffs and paleovalleys in northeastern Nevada-Implications for Eocene paleogeography and extension in the Sevier hinterland, northern Great Basin: Geosphere, v. 4, p. 1-35, https:// doi.org/10.1130/GES00122.1.

Henry, C.D., and John, D.A., 2013, Magmatism, ash-flow tuffs, and calderas of the ignimbrite flareup in the western Nevada volcanic field, Great Basin, USA: Geosphere, August 2013, v. 9, p. 951-1008.

Hon, K., and Lipman, P.W., 1989, Western San Juan caldera complex, in Chapin, C.E., and Zidek, J., eds., Field excursions to volcanic terranes in the western United States, Volume I-Southern Rocky Mountain region: New Mexico Bureau of Mines and Mineral Resources Memoir 46, p. 350-378.

Hora, J.M., Singer, B.S., Jicha, B.R., Beard, B.L., Johnson, C.M., de Silva, S., and Salisbury, M., 2010, Biotite-sanidine ${ }^{40} \mathrm{Ar} /{ }^{39} \mathrm{Ar}$ age discordances reflect complex Ar partitioning and preeruption closure in biotite: Geology, v. 38, p. 923-926.

John, D.A., Henry, C., and Colgan, J., 2008, Tectonic and magmatic evolution of the Caetano Caldera, north-central Nevada-A tilted mid-Tertiary eruptive center and source of the Caetano Tuff: Geosphere, v. 4, p. 75-106.

Johnson, C.M., Shannon, J.R., and Fridrich, C.J., 1989, Roots of ignimbrite calderas-Batholithic plutonism, volcanism, and mineralization in the Southern Rocky Mountains, Colorado and New Mexico: New Mexico Bureau of Mines and Mineral Resources Memoir 46, p. 275-302. 
Karig, D.E., 1965, Geophysical evidence of a caldera at Bonanza, Colorado: U.S. Geological Survey Professional Paper 525-B, B9-B12.

Kennedy, B., Stix, J., Hon, K., Deering, C., and Gelman, S., 2016, Magma storage, differentiation, and interaction at Lake City caldera, Colorado, USA: Geological Society of America Bulletin, v. 128, p. 764-776.

Knepper, D.H., Jr, and Maars, R.W., 1971, Geological development of the Bonanza-San Luis Valley-Sangre de Cristo Range area, south-central Colorado: New Mexico Geological Society Guidebook 22, p. 249-264.

Kouther, M.J.M., 1969, Geology and mineralization of the northwest part of the Bonanza volcanic field, Chafee and Saguache Counties, Colorado: Golden, Colo., Colorado School of Mines, unpub. M.S. thesis, 93 p.

Kuiper, K.F., Deino, A., Hilgen, F.J., Krijgsman, W., Renne, P.R., and Wijbrans, J.R., 2008, Synchronizing rock clocks of earth history: Science, v. 320, p. 500-504.

Larsen, E.S., and Cross, Whitman, 1956, Geology and petrology of the San Juan region, southwestern Colorado: U.S.

Geological Survey Professional Paper 258, 303 p.

Le Bas, M.J., Le Maitre, R.W., Streckeisen, A., and Zanetin, B., 1986, A chemical classification of volcanic rocks based on the total alkali-silica diagram: Journal of Petrology, v. 27, p. $745-750$.

Lindsay, J.M., Schmitt, A.K., Trumbull, R.B., de Silva, S.L., Siebel, W., and Emmermann, R., 2001, Magmatic evolution of the La Pacana caldera system, central Andes, ChileCompositional variation of two cogenetic, large-volume felsic ignimbrites: Journal of Petrology, v. 42, p. 459-486.

Lindsey, D.A., Clark, R.F., and Soulliere, S.J., 1985, Reference section for the Minturn Formation (Middle Pennsylvanian), northern Sangre de Cristo Range, Custer County, Colorado: U.S. Geological Survey Miscellaneous Field Studies Map MF-1622-C.

Lipman, P.W., 1964, A welded tuff dike in southern Nevada: U.S. Geological Survey Professional Paper 501-B, p. B79B81.

Lipman, P.W., 1968, Geology of Summer Coon volcanic center, eastern San Juan Mountains, Colorado: Colorado School of Mines Quarterly, v. 63, no. 3, p. 211-236.

Lipman, P.W., 1975, Evolution of the Platoro caldera complex and related volcanic rocks, southeastern San Juan Mountains, Colorado: U.S. Geological Survey Professional Paper 852, $128 \mathrm{p}$.

Lipman, P.W., 1976a, Geologic map of the Lake City caldera, western San Juan Mountains, Colorado: U.S. Geological Survey Miscellaneous Investigations Series Map I-962.

Lipman, P.W., 1976b, Caldera-collapse breccias in the western San Juan Mountains, Colorado: Geological Society of America Bulletin, v. 87, p. 1397-1410.

Lipman, P.W., 1976c, Geologic map of the Del Norte area, eastern San Juan Mountains, Colorado: U.S. Geological Survey Miscellaneous Investigations Series Map I-952, scale $1: 48,000$.

Lipman, P.W., 1984, The roots of ignimbrite calderasWindows into the tops of granitic batholiths: Journal of Geophysical Research, v. 89, p. 8801-8841.
Lipman, P.W., 1988, Evolution of silicic magma in the upper crust - The mid-Tertiary Latir volcanic field and its cogenetic granitic batholith, northern New Mexico, USA: Transactions of the Royal Society of Edinburgh, v. 79, p. 265-288.

Lipman, P.W., 1997, Subsidence of ignimbrite calderasRelation to caldera size and magma-chamber geometry: Bulletin of Volcanology, v. 59, p. 198-218.

Lipman, P.W., 2000, The central San Juan caldera clusterRegional geologic framework, in Bethke, P.M., and Hay, R.L., eds., Ancient Lake Creede-Its volcanotectonic setting, history of sedimentation, and relation to mineralization in the Creede mining district: Geological Society of America Special Paper 346, p. 9-70.

Lipman, P.W., 2006, Geologic map of the central San Juan caldera complex, southwestern Colorado: U.S. Geological Survey Geologic Investigations Series I-2799, scale $1: 50,000$.

Lipman, P.W., 2007, Incremental assembly and prolonged consolidation of Cordilleran magma chambers-Evidence from the Southern Rocky Mountain volcanic field: Geosphere, v. 3, p. 42-70.

Lipman, P.W., 2012, Geologic map of the Cochetopa Park and North Pass calderas, northeastern San Juan Mountains, Colorado: U.S. Geological Survey Scientific Investigations Map 3123, 1:50,000, 2 sheets, pamphlet, CD-ROM.

Lipman, P.W., and Bachmann, O., 2015, Connecting ignimbrite to batholith in the southern Rocky MountainsIntegrated perspectives from geological, geophysical, and geochronological data: Geosphere, v. 11, p. 705-743.

Lipman, P.W., Doe, B.R., Hedge, C.E., and Steven, T.A., 1978, Petrologic evolution of the San Juan volcanic field, southwestern Colorado- $\mathrm{Pb}$ and $\mathrm{Sr}$ isotope evidence: Geological Society of America Bulletin, v. 89, p. 59-82.

Lipman, P.W., Dungan, M.A., and Bachmann, Olivier, 1997, Eruption of granophyric granite from a large ignimbrite magma chamber-Implications for emplacement of the Fish Canyon Tuff and collapse of the La Garita caldera, San Juan Mountains, Colorado: Geology, v. 25, p. 915-918.

Lipman, P.W., Dungan, M.A., Brown, L.D., and Deino, Allen, 1996, Recurrent eruption and subsidence at the Platoro caldera complex, southeastern San Juan volcanic field, Colorado-New tales from old tuffs: Geological Society of America Bulletin, v. 108, p. 1039-1055.

Lipman, P.W., and McIntosh, W.C., 2008, Eruptive and noneruptive calderas, northeastern San Juan Mountains, Colorado-Where did the ignimbrites come from?: Geological Society of America Bulletin, v. 120, p. 771-795.

Lipman, P.W., McIntosh, W.C., and Zimmerer, M., 2013, From ignimbrite to batholith, northeastern San Juan Mountains, Colorado_Bonanza, Cochetopa Park, and North Pass calderas: Geological Society of America Field Guide 33, p. 357-388.

Lipman, P.W., and Mehnert, H.H., 1975, Late Cenozoic basaltic volcanism and development of the Rio Grande depression in the Southern Rocky Mountains: Geological Society of America Memoir 144, p. 119-153.

Lipman, P.W., Prostka, H.J., and Christiansen, R.L., 1971, Evolving subduction zones in the western United States, as interpreted from igneous rocks: Science, v. 174, p. 821-825. 
Lipman, P.W., Sawyer, D.A., and Hon, K., 1989, Central San Juan caldera cluster: New Mexico Bureau of Mines and Mineral Resources Memoir 46, p. 330-350.

Lipman, P.W., Steven, T.A., Luedke, R.G., and Burbank, W.S., 1973, Revised history of the San Juan Uncompahgre, Silverton, and Lake City calderas in the Western San Juan Mountains: U.S. Geological Survey Journal of Research, v. 1, no. 6, p. 627-642.

Lipman, P.W., Steven, T.A., and Mehnert, H.H., 1970, Volcanic history of the San Juan Mountains, Colorado, as indicated by potassium-argon dating: Geological Society of America Bulletin, v. 81, p. 2327-2352.

Lipman, P.W., and Weston, P.E., 2001, Phenocryst compositions of late ignimbrites from the central San Juan caldera clusterResults from Creede drill-hole samples and implications for regional stratigraphy, in Bethke, P.M., ed., Preliminary scientific results of the Creede caldera continental scientific drilling program: U.S. Geological Survey Open-File Report 94-260B, 43 p.

Lipman, P.W., Zimmerer, M.J., and McIntosh, W.C., 2015, Structural and eruptive history of an ignimbrite caldera from the bottom up-Erosionally exhumed floor and fill of the resurgent Bonanza caldera, Southern Rocky Mountain volcanic field, Colorado: Geosphere, v. 11, p. 1902-1947.

Marrs, R.W., 1973, Application of remote sensing techniques to the geology of the Bonanza volcanic center: Golden, Colo., Colorado School of Mines, Ph.D. dissertation, 281 p.

Marsh, M.R., and McQueen, R.W., 1974, Map showing localities and amounts of metallic mineral production in Colorado: U.S. Geological Survey Mineral Investigations Resource Map 58.

Mason, B.G., Pyle, D.M., and Oppenheimer, C., 2004, The size and frequency of the largest explosive eruptions on Earth: Bulletin of Volcanology, v. 66, p. 735-748.

Mayhew, J.D., 1969, Geology of the eastern part of the Bonanza volcanic field, Saguache County, Colorado: Golden, Colorado School of Mines, unpub. M.S. thesis, 94 p.

McCalpin, J.P., 1982, Quaternary geology and neotectonics of the west flank of the northern Sangre de Cristo Mountains, Colorado: Colorado School of Mines Quarterly, v. 77, no. 3, $97 \mathrm{p}$.

McIntosh, W.C., and Chapin, C.E., 2004, Geochronology of the central Colorado volcanic field: New Mexico Bureau of Geology and Mineral Resources Bulletin 160, p. 205-238.

Memeti, V., and Lipman, P.W., 2014, Exploring volcanicplutonic connections in the Bonanza caldera, Colorado: Geological Society of America Abstracts with Programs, v. 46, p. 374.

Mertzman, S.A., Jr., 1971, The Summer Coon volcano, eastern San Juan Mountains, Colorado, in James, H.L., ed., Guidebook of the San Luis Basin, Colorado: New Mexico Geological Society Twenty-Second Field Conference, $p$. 265-272.

Mills, R.D., and Coleman, DS., 2013, Temporal and chemical connections between plutons and ignimbrites from the Mount Princeton magmatic center: Contributions to Mineralogy and Petrology, v. 165, p. 961-980.

Moore, I., and Kokelaar, P., 1998, Tectonically controlled piecemeal caldera collapse-A case study of Glencoe volcano, Scotland: Geological Society of America Bulletin, v. 110 , p. $1448-1466$.

Nash, J.T., 1988, Geology and geochemistry of the Pitch uranium mine area, Saguache County, Colorado: U.S. Geological Survey Bulletin 1797, 38 p.

Nier, A.O., 1950, A redetermination of the relative abundances of the isotopes of carbon, nitrogen, oxygen, and argon and potassium: Physical Review, v. 77, p. 789-293.

Odé, H., 1957, Mechanical analysis of the dike pattern of the Spanish Peaks area, Colorado: Geological Society of America Bulletin, v. 68, p. 567-576.

Olson, J.C., 1983, Geologic and structural maps and sections of the Marshall Pass Mining District, Saguache, Gunnison, and Chafee Counties, Colorado: U.S. Geological Survey Miscellaneous Investigations Series Map I-1425, scale, $1: 24,000$.

Olson, J.C., 1988, Geology and ore deposits of the Cochetopa and Marshall Pass districts, Saguache and Gunnison Counties, Colorado: U.S. Geological Survey Professional Paper 1457, $44 \mathrm{p}$.

Parat, F., Dungan M.A., and Lipman, P.W., 2005, Contemporaneous trachyandesitic and calc-alkaline volcanism of the Huerto Andesite, San Juan volcanic field, Colorado, USA: Journal of Petrology, v. 46, p. 859-891.

Parker, D.F., Ghosh, A., Price, C.W., Rinard, B.D., Culler, R.L., and Ren, M., 2005, Origin of rhyolite by crustal melting and the nature of parental magmas in the Oligocene Conejos Formation, San Juan Mountains, Colorado, USA: Journal of Volcanology and Geothermal Research, v. 139, p. 183-210.

Patton, H.B., 1916, Geology and ore deposits of the Bonanza District, Saguache County, Colorado: Colorado State Geological Survey Bulletin 9, 136 p.

Perry, H., 1971, Geology of the northern part of the Bonanza volcanic field, Saguache County, Colorado: Colorado School of Mines, unpub. M.S. thesis, $72 \mathrm{p}$.

Plouff, D., and Pakiser, L.C., 1972, Gravity study in the San Juan Mountains, Colorado: U.S. Geological Survey Professional Paper 800, B183-B190.

Quick, J.E., Sinigoi, S., Peressini, G., Demarchi, G., Wooden, J.L., and Sbisà, A., 2009, Magmatic plumbing of a large Permian caldera exposed to a depth of $25 \mathrm{~km}$ : Geology, v. 37 , p. 603-606.

Ratté, J.C., and Steven, T.A., 1967, Ash flows and related volcanic rocks associated with the Creede caldera, San Juan Mountains, Colorado: U.S. Geological Survey Professional Paper 524-H, 58 p.

Renne, P.R., Swisher, C.C., Deino, A.L., Karner, D.B., Owens, T.L., and DePaolo, D.J., 1998, Intercalibration of standards, absolute ages, and uncertainties in ${ }^{40} \mathrm{Ar} /{ }^{39} \mathrm{Ar}$ dating: Chemical Geology, v. 145, p. 117-152.

Riciputi, L.R., Johnson, C.M., Sawyer, D.A., and Lipman, P.W., 1995, Crustal and magmatic evolution in a large multicyclic caldera complex-Isotopic evidence from the central San Juan volcanic field: Journal of Volcanology and Geothermal Research, v. 67, p. 1-28.

Rosenbaum, J.G., Reynolds, R.L., Lipman, P.W., and Sawyer, D.A., 1987, Paleomagnetism of Oligocene ignimbrites, 
central San Juan Mountains, Colorado: Geological Society of America Abstracts with Programs, v. 19, p. 330.

Sbisà, A., 2010, Structure and eruptive history of the Sesia caldera, northwest Italy: University of Trieste, Ph.D. dissertation, $141 \mathrm{p}$.

Schmitz, M.D., and Bowring, S.A., 2001, U-Pb zircon and titanite systematics of the Fish Canyon Tuff-An assessment of high-precision $\mathrm{U}-\mathrm{Pb}$ geochronology and its application to young volcanic rocks: Geochimica et Cosmochimica Acta, v. 65 , p. 2571-2587.

Scott, G.R., Van Alstine, R.E., and Sharp, W.N., 1975, Geologic map of the Poncha Springs quadrangle, Chaffee County, Colorado: U.S. Geological Survey Miscellaneous Field Studies Map MF-658, scale 1:62,500.

Shannon, J.R., 1988, Geology of the Mount Aetna Cauldron Complex: Golden, Colorado School of Mines, Ph.D. dissertation, $434 \mathrm{p}$.

Shannon, J.R., Epis, R.C., Naeser, C.W., and Obradovich, J.D., 1987, Correlation of intracaldera and outflow and an intrusive tuff dike related to the Oligocene Mount Aetna cauldron, central Colorado, in Drexler, J.W., and Larson, E.E., eds., Cenozoic volcanism in the Southern Rocky Mountains revisited: Colorado School of Mines Quarterly, v. 82, no. 4, p. 65-80.

Siems, D.F., 2000, The determination of 30 elements in geological materials by energy-dispersive X-ray fluorescence spectrometry: U.S. Geological Survey Open-File Report 00-475, 13 p.

Smith, R.L., 1960, Ash-flow magmatism: Geological Society of America Bulletin, v. 71, p. 795-842.

Smith, R.L., and Bailey, R.A., 1968, Resurgent cauldrons, in Coates, R.R., Hay, R.L., and Anderson, C.A., eds., Studies in volcanology: Geological Society of America Memoir 116, p. 613-662.

Sparks, R.S.J., Francis, P.W., Hamer, R.D., Pankhurst, R.J., O’Callaghan, L.O., Thorpe, R.S., and Page, R., 1985, Ignimbrites of the Cerro Galan Caldera, northwest Argentina: Journal of Volcanology and Geothermal Research, v. 24, p. 205-248.

Steven, T.A., 1975, Middle Tertiary volcanic field in the Southern Rocky Mountains, in Curtis, B.F., ed., Cenozoic history of the southern Rocky Mountains: Geological Society of America Memoir 144, p. 75-94.

Steven, T.A., and Bieniewski, C.L., 1977, Mineral resources of the La Garita Wilderness, San Juan Mountains, southwestern Colorado: U.S. Geological Survey Bulletin 1420, 65 p.

Steven, T.A., and Hail, W.J., 1989, Geologic map of the Montrose 30' x 60' quadrangle, southwestern Colorado: U.S. Geological Survey Miscellaneous Geologic Investigations Map I-1399, scale, 1:100,000.

Steven, T.A., Hon, Ken, and Lanphere, M.A., 1995, Neogene geomorphic evolution of the central San Juan Mountains near Creede, Colorado: U.S. Geological Survey Miscellaneous Investigations Series Map I-2504, scale 1:100,000.

Steven, T.A., and Lipman, P.W., 1976, Calderas of the San Juan volcanic field, southwestern Colorado: U.S. Geological Survey Professional Paper 958, 35 p.

Steven, T.A., Lipman P.W., Hail, W.J., Jr., Barker, Fred, and Luedke, R.G., 1974, Geologic map of the Durango quadrangle, southwestern Colorado: U.S. Geological Survey Miscellaneous Geologic Investigations Map I-764, scale $1: 250,000$.

Steven, T.A., and Ratté, J.C., 1965, Geology and structural control of ore deposition in the Creede district, San Juan Mountains, Colorado: U.S. Geological Survey Professional Paper 487, 90 p.

Steven, T.A., and Ratté, J.C., 1973, Geologic map of the Creede quadrangle, Mineral and Saguache Counties, Colorado: U.S. Geological Survey Geologic Quadrangle Map GQ-1053.

Taggart, J.E., Jr., Lindsey, J.R., Scott, B.A., Vivit, D.V., Bartel, A.J., and Stewart, K.C., 1987, Analysis of geologic materials by wavelength-dispersive X-ray fluorescence spectrometry, in Baedecker, P.A., ed., Methods for geochemical analyses: U.S. Geological Survey Professional Paper 1770, p. E1-E19.

Tanaka, H., and Kono, M., 1973, Paleomagnetism of the San Juan volcanic field, Colorado: Rock Magnetism and Paleophysics, v. 1, p. 71-76.

Toulmin, Priestly, III, and Hammarstrom, J.M., 1990, Geology of the Mount Aetna volcanic center, Chafee and Gunnison Counties, Colorado: U.S. Geological Survey Bulletin 1864, $44 \mathrm{p}$.

Tweto, O., 1978, The Rio Grande rift system in Colorado, in Riecker, R.E., ed., Rio Grande rift-Tectonics and magmatism: Washington, D.C., American Geophysical Union, p. 33-56.

Tweto, O., 1979, Geologic map of Colorado: U.S. Geological Survey Special Map, scale 1:500,000.

Tweto, O., Steven, T.A., Hail, W.J., Jr., and Moench, R.H., 1976, Preliminary geologic map of the Montrose $1^{\circ} \times 2^{\circ}$ quadrangle, southwestern Colorado: U.S. Geological Survey Miscellaneous Field Studies Map MF-761, scale, 1:250,000.

Van Alstine, R.E., 1968, Tertiary trough between the Arkansas and San Luis valleys, Colorado: U.S. Geological Survey Professional Paper 600-C, p. C158-C160.

Van Alstine, R.E., 1975, Geologic map of the Bonanza NE quadrangle, Chafee and Saguache counties, Colorado: U.S. Geological Survey Open-File Report 75-53.

Varga, R.J., and Smith, B.M., 1984, Evolution of the early Oligocene Bonanza caldera, northeast San Juan volcanic field, Colorado: Journal of Geophysical Research, v. 89, p. 8679-8694.

Webber, K.L., 1988, The Mammoth Mountain and Wason Park Tuffs-Magmatic evolution in the central San Juan volcanic field, southwestern Colorado: Houston, Tex., Rice University, Ph.D. thesis, 244 p.

Whitney, J.A., Dorais, M.J., Stormer, J.C., Jr., Kline, S.W., and Matty, D.J., 1988, Magmatic conditions and development of chemical zonation in the Carpenter Ridge Tuff, central San Juan volcanic field, Colorado: American Journal of Science, v. 288-A, p. 16-44.

Whitney, J.A., and Stormer, J.C., Jr., 1985, Mineralogy, petrology, and magmatic conditions from the Fish Canyon Tuff, central San Juan volcanic field, Colorado: Journal of Petrology, v. 26, p. 726-762.

Willcock, M.A.W., Cas, R.A.F., Giordano, G., and Morelli, C., 2013, The eruption, pyroclastic flow behavior, and 
caldera in-filling processes of the extremely large volume $\left(1,290 \mathrm{~km}^{3}\right)$ intra- to extra-caldera Permian Ora (ignimbrite) Formation, southern Alps, Italy: Journal of Volcanology and Geothermal Research, v. 265, p. 102-126.

Zimmerer, M.J., and McIntosh, W.C., 2011, ${ }^{40} \mathrm{Ar} /{ }^{39} \mathrm{Ar}$ dating, sanidine chemistry, and potential sources of the Las Tablas Tuff, northern New Mexico, in Geology of the Tusas Mountains - Ojo Caliente: New Mexico Geological Society Guidebook, 62nd Field Conference, p. 121-127.
Zimmerer, M.J., and McIntosh, W.C., 2012a, The geochronology of volcanic and plutonic rocks at the Questa calderaConstraints on the origin of caldera-related silicic magmas: Geological Society of America Bulletin, v. 124, p. 1394-1408.

Zimmerer, M.J., and McIntosh, W.C., 2012b, An investigation of caldera-forming magma chambers using the timing of ignimbrite eruptions and pluton emplacement at the Mt. Aetna caldera complex: Journal of Volcanology and Geothermal Research, v. 245-246, p. 128-148. 
Table 1. Summary of major ignimbrites, caldera sources, and ${ }^{40} \mathrm{Ar} /{ }^{39} \mathrm{Ar}$ ages, Southern Rocky Mountain volcanic field, southwestern Colorado. Listed according to age, younger to older.

[Updated and simplified from Lipman, 2012, table 1. --, no data]

\begin{tabular}{|c|c|c|c|c|c|c|}
\hline \multicolumn{5}{|c|}{ Ignimbrite } & \multicolumn{2}{|l|}{ Caldera } \\
\hline Tuff & Percent $\mathrm{SiO}_{2}$ & Rock, phenocrysts ${ }^{1}$ & Vol $\left(\mathbf{k m}^{3}\right)$ & Age (Ma) & Name & Area $(\mathbf{k m})$ \\
\hline \multicolumn{7}{|c|}{ West San Juan Mountains } \\
\hline Sunshine Peak & Zoned: $76-68$ & Qtz, sodic san & $200-500$ & 23.0 & Lake City & $15 \times 18$ \\
\hline \multicolumn{7}{|c|}{ Latir Mountains, New Mexico } \\
\hline Amalia & $76-77$ & Peralkaline: qtz, sodic san & 500 & 25.1 & Questa & $14 x>15$ \\
\hline \multicolumn{7}{|c|}{ Central San Juan Mountains } \\
\hline Snowshoe Mountain & $62-66$ & Xl-rich dacite & $>500$ & 26.9 & Creede & $20 \times 25$ \\
\hline \multicolumn{7}{|c|}{ Central San Juan Mountains: San Luis caldera complex } \\
\hline Nelson Mountain & Zoned: $74-63$ & Xp rhy; $x l$ dacite & $>500$ & 26.9 & San Luis-Cochetopa & $9 \times 9,20 \times 25$ \\
\hline Cebolla Creek & $61-64$ & $\mathrm{Xl}$ dacite, hbl, no san & 250 & 26.9 & San Luis complex & $14 \times 16$ \\
\hline Rat Creek & Zoned: $74-65$ & Xp rhy-xl dacite & 150 & 26.9 & San Luis complex & $9 \times 12$ \\
\hline \multicolumn{7}{|c|}{ Central San Juan Mountains } \\
\hline Wason Park & Zoned: $72-63$ & $\mathrm{X} 1$ rhyolite-dacite & $>500$ & 27.4 & South River & $20 \times 20$ \\
\hline Blue Creek & $64-68$ & Xl dacite, no san & 250 & $\sim 27.45$ & [concealed] & -- \\
\hline Carpenter Ridge & Zoned: $74-66$ & Xp rhy $-\mathrm{xl}$ dacite & $>1,000$ & 27.55 & Bachelor & $25 \times 30$ \\
\hline \multicolumn{7}{|c|}{ West San Juan Mountains } \\
\hline Crystal Lake & $72-74$ & Xp rhyolite & $50-100$ & 27.6 & Silverton & $20 \times 20$ \\
\hline \multicolumn{7}{|c|}{ Central San Juan Mountains } \\
\hline Fish Canyon & $66-68$ & $\mathrm{Xl}$ dacite, hbl, qtz & 5,000 & 28.0 & La Garita & $35 \times 75$ \\
\hline \multicolumn{7}{|c|}{ West San Juan Mountains } \\
\hline Sapinero Mesa & $72-75$ & Xp rhyolite & $>1,000$ & 28.3 & Uncompahgre-San Juan & $20 \times 45$ \\
\hline Dillon Mesa & $72-75$ & Xp rhyolite & $50-100$ & 28.5 & Uncompahgre? & $20 \times 20$ \\
\hline Blue Mesa & $72-74$ & Xp rhyolite & $200-500$ & 28.5 & Lost Lakes (buried) & $10 \times 10$ \\
\hline Ute Ridge & $66-68$ & Xl dacite, sanidine & $250-500$ & 28.6 & Ute Creek & $8 \times 8$ \\
\hline \multicolumn{7}{|c|}{ Southeast San Juan Mountains (Treasure Mountain Group) } \\
\hline Chiquito Peak & $64-67$ & $\mathrm{X} 1$ dacite, sanidine & $500-1,000$ & 28.6 & Platoro & $18 \times 22$ \\
\hline \multicolumn{7}{|c|}{ Central San Juan Mountains } \\
\hline Masonic Park & $62-66$ & $\mathrm{Xl}$ dacite, no san & 500 & 28.7 & [concealed] & -- \\
\hline \multicolumn{7}{|c|}{ Southeast San Juan Mountains (Treasure Mountain Group) } \\
\hline South Fork & $68-70$ & $\mathrm{Xl}$ dacite, sanidine & $50-100$ & 28.8 & Platoro/ Summitville? & $8 \times 12 ?$ \\
\hline Ra Jadero & $64-66$ & $\mathrm{Xl}$ dacite, sanidine & 150 & 28.9 & Summitville? & $8 \times 12$ \\
\hline Ojito Creek & $67-70$ & $\mathrm{Xl}$ dacite, no san & 100 & $\sim 29.5$ & Summitville? & $8 \times 12$ \\
\hline La Jara Canyon & $66-68$ & $\mathrm{Xl}$ dacite, no san & $500-1,000$ & 30 & Platoro & $20 \times 24$ \\
\hline Black Mountain & $67-69$ & $\mathrm{Xl}$ dacite, no san & $200-500$ & 30.1 & Platoro & -- \\
\hline \multicolumn{7}{|c|}{ Northeast San Juan Mountains } \\
\hline Saguache Creek & $73-75$ & Alkali rhyolite, no bio & $250-500$ & 32.2 & North Pass & $15 \times 17$ \\
\hline Bonanza & Zoned: $76-60$ & Zoned: rhy-dac-rhy-dac & 1,000 & 33.1 & Bonanza & $15 \times 20$ \\
\hline Thorn Ranch & 77 & Xl dacite; Xp rhyolite & $250-500 ?$ & 33.9 & Marshall Creek & $10 \times 10 ?$ \\
\hline \multicolumn{7}{|c|}{ North-South Sawatch Range Trend } \\
\hline Badger Creek & $69-70$ & $\mathrm{X} 1$ dacite & $250 ?$ & 34.0 & Mount Aetna & $10 \times 15$ \\
\hline Grizzly Peak & Zoned: $77-57$ & $\mathrm{X} 1$ rhy-dacite-andesite & $500 ?$ & 34.3 & Grizzly Peak & $15 \times 17$ \\
\hline Wall Mountain & $70-73$ & $\mathrm{Xl}$ rhyolite & $1,000 \pm$ & 36.9 & Mount Princeton & $15 \times 30 ?$ \\
\hline
\end{tabular}

\footnotetext{
${ }^{1}$ Abbreviations: bio, biotite; dac, dacite; hbl, hornblende; qtz, quartz; rhy, rhyolite; san, sanidine; Xl, crystal-rich; Xp, crystal-poor.
} 
Table 2. Characteristic features, ignimbrite sheets of central and northeastern San Juan Mountains, southwestern Colorado.

\begin{tabular}{|c|c|c|}
\hline Ignimbrite sheet $^{1}$ & Composition $^{2}$ & Textures and phenocrysts \\
\hline Snowshoe Mountain Tuff & Mafic dacite & $\begin{array}{l}\text { Phenocryst rich; densely welded within caldera, weakly welded } \\
\text { outflow }\end{array}$ \\
\hline Nelson Mountain Tuff & Low-Si rhyolite $\Rightarrow$ dacite & $\begin{array}{l}\text { Compositionally zoned; weakly welded crystal poor, to densely } \\
\text { welded crystal rich }\end{array}$ \\
\hline Cebolla Creek Tuff & Mafic dacite & Typically weakly welded; abundant hornblende $\gg>$ augite is distinctive \\
\hline Rat Creek Tuff & Low-Si rhyolite $\Rightarrow$ dacite & $\begin{array}{l}\text { Compositionally zoned; weakly welded rhyolite to densely welded } \\
\text { dacite }\end{array}$ \\
\hline Wason Park Tuff & Rhyolite & Phenocryst-rich rhyolite; tabular sanidine phenocrysts \\
\hline Blue Creek Tuff & Dacite & $\begin{array}{l}\text { Phenocryst rich; sanidine is absent (contrast with Mammoth Mountain } \\
\text { Member) }\end{array}$ \\
\hline \multicolumn{3}{|l|}{ Carpenter Ridge Tuff } \\
\hline Mammoth Mountain Member (upper) & Dacite & Phenocryst rich; sanidine is common (contrast with Blue Creek Tuff) \\
\hline Outflow and lower intracaldera tuff & Low-Si rhyolite & Phenocryst poor; common basal vitrophyre, central lithophysal zone \\
\hline Crystal Lake Tuff & Low-Si rhyolite & Similar to rhyolitic Carpenter Ridge Tuff \\
\hline Fish Canyon Tuff & Dacite & $\begin{array}{l}\text { Distinctive light gray, phenocryst rich; resorbed quartz, hornblende, } \\
\text { absence of augite }\end{array}$ \\
\hline Sapinero Mesa Tuff & Low-Si rhyolite & $\begin{array}{l}\text { Similar to rhyolitic Carpenter Ridge Tuff but generally less welded } \\
\text { within map area }\end{array}$ \\
\hline Dillon Mesa Tuff & Low-Si rhyolite & Similar to rhyolitic Carpenter Ridge Tuff but generally less welded \\
\hline Blue Mesa Tuff & Low-Si rhyolite & Similar to rhyolitic Carpenter Ridge Tuff \\
\hline Ute Ridge Tuff & Dacite & $\begin{array}{l}\text { Phenocryst rich; contains sparse sanidine (in contrast to Masonic Park } \\
\text { Tuff) }\end{array}$ \\
\hline Masonic Park Tuff & Dacite & Phenocrysts similar to Blue Creek Tuff; typically less welded \\
\hline Luders Creek Tuff & Low-Si rhyolite $\Rightarrow$ dacite & Compositionally zoned; resembles Nelson Mountain Tuff \\
\hline Saguache Creek Tuff & Low-Si rhyolite & $\begin{array}{l}\text { Resembles Carpenter Ridge and Sapinero Mesa Tuffs, but lacks } \\
\text { phenocrystic biotite }\end{array}$ \\
\hline Bonanza Tuff & Zoned complexly & $\begin{array}{l}\text { Local basal crystal-poor rhyolite, lower crystal dacite, upper rhyolite, } \\
\text { local upper crystal dacite }\end{array}$ \\
\hline Thorn Ranch Tuff & Zoned complexly & $\begin{array}{l}\text { Intracaldera alternation of rhyolite and dacite; outflow mainly high-Si } \\
\text { rhyolite }\end{array}$ \\
\hline Badger Creek Tuff & Dacite & Crystal rich; resembles Fish Canyon Tuff \\
\hline Wall Mountain Tuff & Rhyolite & Crystal-rich, large blocky sanidine; locally complexly rheomorphic \\
\hline
\end{tabular}

\footnotetext{
${ }^{1}$ Bold type, ignimbrite sheets of Bonanza map area
}

${ }_{2} \mathrm{Si}, \mathrm{SiO}_{2}$ 
Table 3. Representative compositions, volcanic and intrusive rocks of Bonanza caldera region, southwestern Colorado. Determined by X-ray Fluorescence methods, at Washington State University GeoAnalytical Laboratory, mainly 2006-2012.

\begin{tabular}{|c|c|c|c|c|c|c|c|c|c|c|c|c|c|c|c|}
\hline \multirow{2}{*}{$\begin{array}{c}\text { Sample } \\
\text { No. }\end{array}$} & \multirow{2}{*}{$\begin{array}{l}\text { Quad- } \\
\text { rangle }^{1}\end{array}$} & \multirow{2}{*}{$\begin{array}{c}\text { Map } \\
\text { unit } \\
\text { label }\end{array}$} & \multirow{2}{*}{ Rock type, location ${ }^{2}$} & \multirow{2}{*}{$\begin{array}{c}{ }^{40} \mathrm{Ar} /{ }^{39} \mathrm{Ar} \\
\mathrm{age}^{3}\end{array}$} & \multicolumn{2}{|c|}{ Latitude $^{4}$} & \multicolumn{2}{|c|}{ Longitude $^{4}$} & \multicolumn{7}{|c|}{ [ANALYSES, NORMALIZED TO ORIGINAL } \\
\hline & & & & & Deg & Min & Deg & Min & $\mathrm{SiO}_{2}$ & $\mathrm{TiO}_{2}$ & $\mathrm{Al}_{2} \mathrm{O}_{3}$ & $\mathrm{FeTO}_{3}$ & MgO & $\mathrm{CaO}$ & $\mathrm{Na}_{2} \mathrm{O}$ \\
\hline \multicolumn{16}{|c|}{ Hinsdale Formation } \\
\hline $00 \mathrm{~L}-1$ & LG & Thb & $\begin{array}{l}\text { Basaltic lava flow, } \\
\text { Houghland Hill }\end{array}$ & 21.81 & 38 & 7.43 & 106 & 17.72 & 50.14 & 1.86 & 14.83 & 11.53 & 7.30 & 8.03 & 2.99 \\
\hline \multicolumn{16}{|c|}{ BONANZA CALDERA CYCLE (33 Ma) } \\
\hline \multicolumn{16}{|c|}{ Late Intrusions } \\
\hline $11 \mathrm{~L}-8$ & WH & Tas & $\begin{array}{l}\text { Interior granite, Spring } \\
\text { Creek }\end{array}$ & & 38 & 19.22 & 106 & 4.73 & 72.84 & 0.29 & 13.92 & 1.74 & 0.38 & 0.64 & 4.15 \\
\hline 06L-34 & GG & Tas & $\begin{array}{l}\text { Sparsely porphyritic } \\
\text { aplite, Spring Creek }\end{array}$ & 33.26 & 38 & 19.43 & 106 & 3.36 & 77.60 & 0.17 & 12.60 & 0.74 & $<0.10$ & 0.24 & 3.61 \\
\hline 08L-4B & WH & $\operatorname{Ttg}$ & $\begin{array}{l}\text { Granodiorite, Ridge, } \\
\text { north of Kelly Creek }\end{array}$ & & 38 & 17.63 & 106 & 3.71 & 62.42 & 0.60 & 17.41 & 4.54 & 0.72 & 3.81 & 4.55 \\
\hline 08L-41 & WH & Tta & $\begin{array}{l}\text { Intrusive andesite, Ridge, } \\
\text { north of Kelly Creek }\end{array}$ & 33.06 & 38 & 17.62 & 106 & 3.53 & 54.14 & 1.61 & 15.62 & 9.20 & 4.29 & 6.12 & 3.35 \\
\hline 06L-35 & GG & $\operatorname{Ttg}$ & $\begin{array}{l}\text { Coarse gabbro, Peterson } \\
\text { Creek }\end{array}$ & & 38 & 17.89 & 106 & 3.38 & 55.17 & 1.49 & 15.91 & 8.71 & 3.68 & 5.57 & 3.30 \\
\hline \multicolumn{16}{|c|}{ Postcaldera lava flows } \\
\hline 08L-17 & $\mathrm{BZ}$ & Tbfr & $\begin{array}{l}\text { Crystal-poor rhyolite, } \\
\text { Porphyry Peak }\end{array}$ & & 38 & 21.35 & 106 & 9.09 & 74.67 & 0.23 & 13.73 & 0.80 & 0.20 & 0.41 & 3.19 \\
\hline $07 \mathrm{~L}-53$ & WH & Tbdh & $\begin{array}{l}\text { Dacite of Hayden Peak, } \\
\text { Hayden Peak, east }\end{array}$ & 32.64 & 38 & 16.47 & 106 & 6.01 & 69.73 & 0.45 & 15.42 & 1.99 & 0.31 & 0.86 & 4.52 \\
\hline 08L-44 & $\mathrm{BZ}$ & Tbdk & $\begin{array}{l}\text { Large-sanidine dacite } \\
\text { flow, Silver Creek }\end{array}$ & 32.76 & 38 & 21.39 & 106 & 10.24 & 65.65 & 0.69 & 15.50 & 3.99 & 1.65 & 3.22 & 4.05 \\
\hline $13 \mathrm{~L}-4$ & $\mathrm{BZ}$ & Tbfd & $\begin{array}{l}\text { Upper dacite flow, } \\
\text { Slaughterhouse road }\end{array}$ & & 38 & 18.14 & 106 & 10.39 & 64.61 & 0.70 & 16.71 & 4.13 & 0.70 & 2.83 & 4.17 \\
\hline 10L-19B & LMNE & Tbam & $\begin{array}{l}\text { Malpais andesite, Bear } \\
\text { Creek }\end{array}$ & & 38 & 14.84 & 106 & 19.52 & 58.69 & 1.10 & 17.18 & 6.66 & 2.47 & 5.30 & 3.66 \\
\hline 07L-56 & $\mathrm{BZ}$ & Tbas & $\begin{array}{l}\text { Squirrel Gulch Andesite, } \\
\text { Kerber Creek }\end{array}$ & 33.38 & 38 & 19.32 & 106 & 9.66 & 58.85 & 0.93 & 17.11 & 6.26 & 2.81 & 5.39 & 3.75 \\
\hline \multicolumn{16}{|c|}{ Bonanza Tuff } \\
\hline \multicolumn{16}{|c|}{ Outflow west } \\
\hline 09L-8A & $\mathrm{KM}$ & Tbdu & $\begin{array}{l}\text { Bonanza Tuff, upper } \\
\text { dacite, Findley Ridge }\end{array}$ & & 38 & 7.88 & 106 & 11.98 & 61.76 & 0.82 & 17.64 & 4.98 & 1.21 & 3.64 & 4.03 \\
\hline 09L-8B & KM & Tbru & $\begin{array}{l}\text { Bonanza Tuff, upper } \\
\text { rhyolite, Findley Ridge }\end{array}$ & (33.07) & 38 & 7.85 & 106 & 11.97 & 74.14 & 0.22 & 13.06 & 1.35 & 0.26 & 1.09 & 4.02 \\
\hline 09L-8D & $\mathrm{KM}$ & Tbd & $\begin{array}{l}\text { Bonanza Tuff, mid lower } \\
\text { dacite, Findley Ridge }\end{array}$ & $(33.41)$ & 38 & 7.78 & 106 & 11.83 & 63.49 & 0.81 & 17.27 & 3.82 & 1.06 & 4.24 & 3.98 \\
\hline 09L-33B & $\mathrm{LN}$ & Tbd & $\begin{array}{l}\text { Mafic scoria, resorb K-f, } \\
\text { Jacks Creek tributary }\end{array}$ & & 38 & 12.09 & 106 & 21.07 & 63.91 & 0.63 & 17.29 & 3.31 & 0.96 & 2.50 & 4.04 \\
\hline $11 \mathrm{~L}-10 \mathrm{~A}$ & KM & Tbd & $\begin{array}{l}\text { Mafic scoria, upper unit } \\
\text { (no K-f), Findley Ridge }\end{array}$ & & 38 & 7.84 & 106 & 11.93 & 59.72 & 0.95 & 17.77 & 5.35 & 1.94 & 4.33 & 3.91 \\
\hline \multicolumn{16}{|c|}{ Outflow east (Gribbles Park Tuff) } \\
\hline 08L-33A & $\mathrm{JH}$ & Tbrl & $\begin{array}{l}\text { Lower crystal-poor } \\
\text { rhyolite, Two Creek } \\
\text { section }\end{array}$ & $(33.09)$ & 38 & 36.49 & 105 & 46.79 & 74.57 & 0.28 & 13.07 & 1.23 & 0.26 & 0.75 & 3.80 \\
\hline \multicolumn{16}{|c|}{ Rawley volcanic complex ( $\sim 33.3-33.8 \mathrm{Ma})$} \\
\hline 08L-26 & GG & Trfr & $\begin{array}{l}\text { Rhyolite flow, north of } \\
\text { Kerber junction }\end{array}$ & 33.81 & 38 & 13.09 & 106 & 4.79 & 71.23 & 0.31 & 14.74 & 1.34 & 0.09 & 0.41 & 4.12 \\
\hline 08L-25 & GG & Trd & $\begin{array}{l}\text { Basal dacite flow, Kerber } \\
\text { Creek }\end{array}$ & & 38 & 13.06 & 106 & 4.69 & 62.91 & 0.82 & 16.52 & 4.69 & 1.64 & 3.63 & 3.98 \\
\hline
\end{tabular}




\section{TOTALS WITHOUT VOLATILES]}

\begin{tabular}{|c|c|c|c|c|c|c|c|c|c|c|c|c|c|c|c|c|c|c|}
\hline $\mathrm{K}_{2} \mathrm{O}$ & $\mathbf{P}_{2} \mathbf{O}_{5}$ & MnO & LOI & Total & Zn & $\mathbf{R b}$ & Sr & $\mathbf{Y}$ & $\mathrm{Zr}$ & Nb & $\mathrm{Pb}$ & $\mathrm{Ba}$ & La & $\mathrm{Ce}$ & Nd & V & $\mathbf{G a}$ & $\mathrm{Ni}$ \\
\hline 2.68 & 0.49 & 0.14 & 2.87 & 99.99 & 101 & 53 & 653 & 21 & 160 & 21 & 5 & 686 & 23 & 54 & 26 & 220 & 22 & 140 \\
\hline 5.12 & 0.10 & 0.03 & 0.77 & 100.20 & 36 & 233 & 10 & 10 & 128 & 45 & 36 & 22 & 58 & 106 & 30 & 14 & 13 & 2 \\
\hline 3.72 & 0.38 & 0.09 & 1.26 & 98.24 & 94 & 72 & 985 & 24 & 266 & 17 & 14 & 1752 & 63 & 124 & 57 & 48 & 19 & 0 \\
\hline 3.46 & 0.67 & 0.15 & 0.18 & 98.61 & 131 & 120 & 836 & 38 & 472 & 43 & 17 & 1227 & 89 & 192 & 81 & 207 & 22 & 25 \\
\hline 5.55 & 0.03 & 0.01 & 1.26 & 98.83 & 41 & 198 & 37 & 16 & 203 & 39 & 28 & 106 & 41 & 67 & 23 & 8 & 17 & 0 \\
\hline 5.77 & 0.06 & 0.06 & 1.03 & 99.18 & 69 & 144 & 261 & 31 & 378 & 28 & 30 & 1825 & 57 & 116 & 50 & 10 & 17 & 0 \\
\hline 4.24 & 0.27 & 0.07 & 1.16 & 99.33 & 77 & 122 & 583 & 23 & 254 & 29 & 20 & 1063 & 63 & 112 & 41 & 79 & 20 & 11 \\
\hline 4.72 & 0.28 & 0.16 & 0.94 & 99.03 & 77.1 & 141 & 646 & 29 & 362 & 28 & 20 & 1579 & 74 & 138 & 57 & 84 & 21 & 8 \\
\hline 3.49 & 0.45 & 0.12 & 0.92 & 99.11 & 90 & 72 & 931 & 26 & 215 & 16 & 14 & 1465 & 43 & 97 & 47 & 133 & 20 & 14 \\
\hline
\end{tabular}

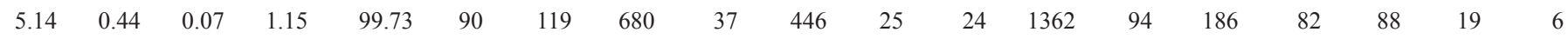

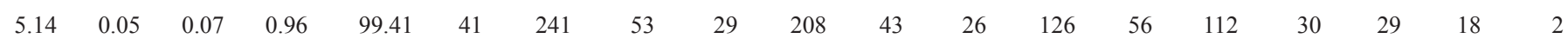

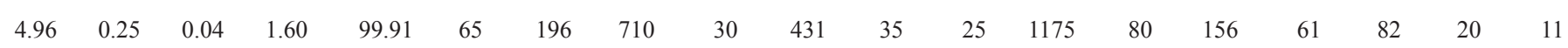

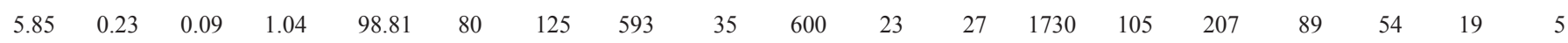

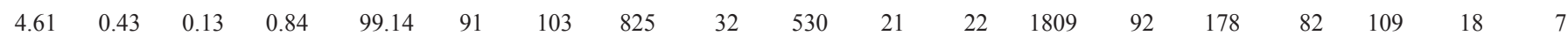

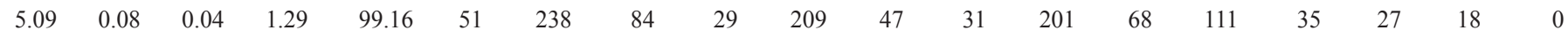

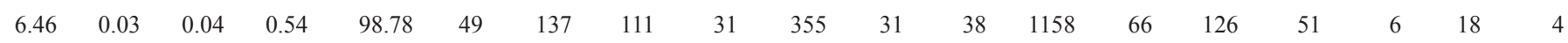

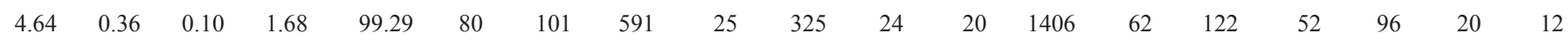


Table 3. Representative compositions, volcanic and intrusive rocks of Bonanza caldera region, southwestern Colorado. Determined by X-ray Fluorescence methods, at Washington State University GeoAnalytical Laboratory, mainly 2006-2012.-Continued

\begin{tabular}{|c|c|c|c|c|c|c|c|c|c|c|c|c|c|c|c|}
\hline \multirow{2}{*}{$\begin{array}{c}\text { Sample } \\
\text { No. }\end{array}$} & \multirow{2}{*}{$\begin{array}{l}\text { Quad- } \\
\text { rangle }^{1}\end{array}$} & \multirow{2}{*}{$\begin{array}{c}\text { Map } \\
\text { unit } \\
\text { label }\end{array}$} & \multirow{2}{*}{ Rock type, location ${ }^{2}$} & \multirow{2}{*}{$\begin{array}{c}{ }^{40} \mathrm{Ar} /{ }^{39} \mathrm{Ar} \\
\text { age }^{3}\end{array}$} & \multicolumn{2}{|c|}{ Latitude $^{4}$} & \multicolumn{2}{|c|}{ Longitude $^{4}$} & \multicolumn{7}{|c|}{ [ANALYSES, NORMALIZED TO ORIGINAL } \\
\hline & & & & & Deg & Min & Deg & Min & $\mathrm{SiO}_{2}$ & $\mathrm{TiO}_{2}$ & $\mathrm{Al}_{2} \mathrm{O}_{3}$ & $\mathrm{FeTO}_{3}$ & $\mathrm{MgO}$ & $\mathrm{CaO}$ & $\mathrm{Na}_{2} \mathrm{O}$ \\
\hline 07L-3 & KM & Trap & $\begin{array}{l}\text { Dark plag andesite, Ute } \\
\text { Pass road }\end{array}$ & 33.35 & 38 & 10.47 & 106 & 8.08 & 58.04 & 1.08 & 16.30 & 6.83 & 3.01 & 5.88 & 3.82 \\
\hline \multicolumn{16}{|c|}{ MARSHALL CALDERA CYCLE (34 Ma) } \\
\hline \multicolumn{16}{|c|}{ Lava fill of Marshall caldera ( $\sim=$ Rawley volcanic complex) } \\
\hline $10 \mathrm{~L}-27$ & $\mathrm{CH}$ & Tmfr & $\begin{array}{l}\text { Rhyolite flow, Duncan } \\
\text { Creek }\end{array}$ & & 38 & 21.38 & 106 & 18.62 & 76.12 & 0.11 & 12.89 & 0.73 & 0.09 & 0.68 & 3.56 \\
\hline 08L-35 & $\mathrm{BZ}$ & Tmds & $\begin{array}{l}\text { Sheep Mountain Dacite, } \\
\text { Sheep Mountain }\end{array}$ & 32.89 & 38 & 21.58 & 106 & 11.68 & 65.25 & 0.45 & 15.94 & 2.70 & 1.22 & 3.28 & 3.77 \\
\hline 07L-22 & KM & Tra & $\begin{array}{l}\text { Aphanitic andesite, Mill } \\
\text { Gulch }\end{array}$ & 32.61 & 38 & 12.56 & 106 & 14.81 & 56.58 & 0.99 & 17.63 & 7.04 & 2.66 & 5.70 & 4.37 \\
\hline \multicolumn{16}{|c|}{ Thorn Ranch Tuff-Distal outflow } \\
\hline 09L-10C & $\mathrm{BM}$ & Ttr & $\begin{array}{l}\text { Lower, partly welded, } \\
\text { south Tallahassee Creek }\end{array}$ & 33.90 & 38 & 31.18 & 105 & 33.65 & 74.82 & 0.19 & 13.27 & 1.22 & 0.45 & 0.71 & 2.33 \\
\hline \multicolumn{16}{|c|}{ Intracaldera } \\
\hline $08 \mathrm{~A}-2$ & $\mathrm{BZ}$ & Ttr & $\begin{array}{l}\text { Crystal-poor rhyolite, } \\
\text { Silver Creek }\end{array}$ & & 38 & 21.62 & 106 & 10.79 & 73.09 & 0.26 & 13.96 & 1.48 & 0.41 & 1.19 & 1.35 \\
\hline 08L-39 & MO & Ttr & $\begin{array}{l}\text { Dacite, ridge crest, } \\
\text { Starvation Creek }\end{array}$ & 33.89 & 38 & 23.08 & 106 & 12.44 & 66.24 & 0.37 & 15.85 & 2.21 & 0.33 & 3.45 & 3.89 \\
\hline
\end{tabular}

${ }^{1}$ See figure 3 (sheet 1) for quadrangle name and location.

2 Abbreviations: K-f, potassium feldspar; plag, plagioclase

${ }^{3}$ Parentheses, age determined on different sample from this site (McIntosh and Chapin, 2004)

${ }^{4}$ Deg, degrees; min, minutes 


\begin{tabular}{|c|c|c|c|c|c|c|c|c|c|c|c|c|c|c|c|c|c|c|}
\hline \multicolumn{19}{|c|}{ TOTALS WITHOUT VOLATILES] } \\
\hline $\mathrm{K}_{2} \mathrm{O}$ & $\mathbf{P}_{2} \mathbf{O}_{5}$ & MnO & LOI & Total & $\mathrm{Zn}$ & $\mathbf{R b}$ & Sr & $\mathbf{Y}$ & $\mathrm{Zr}$ & $\mathrm{Nb}$ & $\mathbf{P b}$ & $\mathrm{Ba}$ & La & $\mathrm{Ce}$ & Nd & $\mathbf{v}$ & $\mathbf{G a}$ & $\mathrm{Ni}$ \\
\hline 3.29 & 0.44 & 0.09 & 1.43 & 98.79 & 91 & 77 & 889 & 25 & 261 & 18 & 15 & 1369 & 54 & 106 & 47 & 168 & 19 & 54 \\
\hline 5.24 & 0.02 & 0.05 & 0.64 & 99.48 & 27 & 195 & 63 & 10 & 97 & 24 & 27 & 109 & 32 & 49 & 19 & 3 & 18 & 3 \\
\hline 6.30 & 0.16 & 0.12 & 3.62 & 99.19 & 56 & 108 & 364 & 22 & 479 & 20 & 22 & 1310 & 72 & 142 & 55 & 29 & 16 & 0 \\
\hline 3.63 & 0.61 & 0.13 & 0.65 & 99.35 & 108 & 73 & 1150 & 28 & 350 & 19 & 17 & 1712 & 80 & 162 & 69 & 140 & 21 & 1 \\
\hline 5.82 & 0.03 & 0.05 & 4.52 & 98.89 & 65 & 233 & 45 & 32 & 162 & 33 & 35 & 116 & 47 & 92 & 38 & 11 & 17 & 2 \\
\hline 6.95 & 0.05 & 0.11 & 2.38 & 98.84 & 114 & 249 & 52 & 29 & 248 & 31 & 19 & 246 & 76 & 145 & 55 & 10 & 19 & 0 \\
\hline 6.60 & 0.10 & 0.06 & 3.00 & 99.10 & 69 & 113 & 183 & 25 & 458 & 24 & 27 & 663 & 95 & 179 & 66 & 15 & 18 & 0 \\
\hline
\end{tabular}




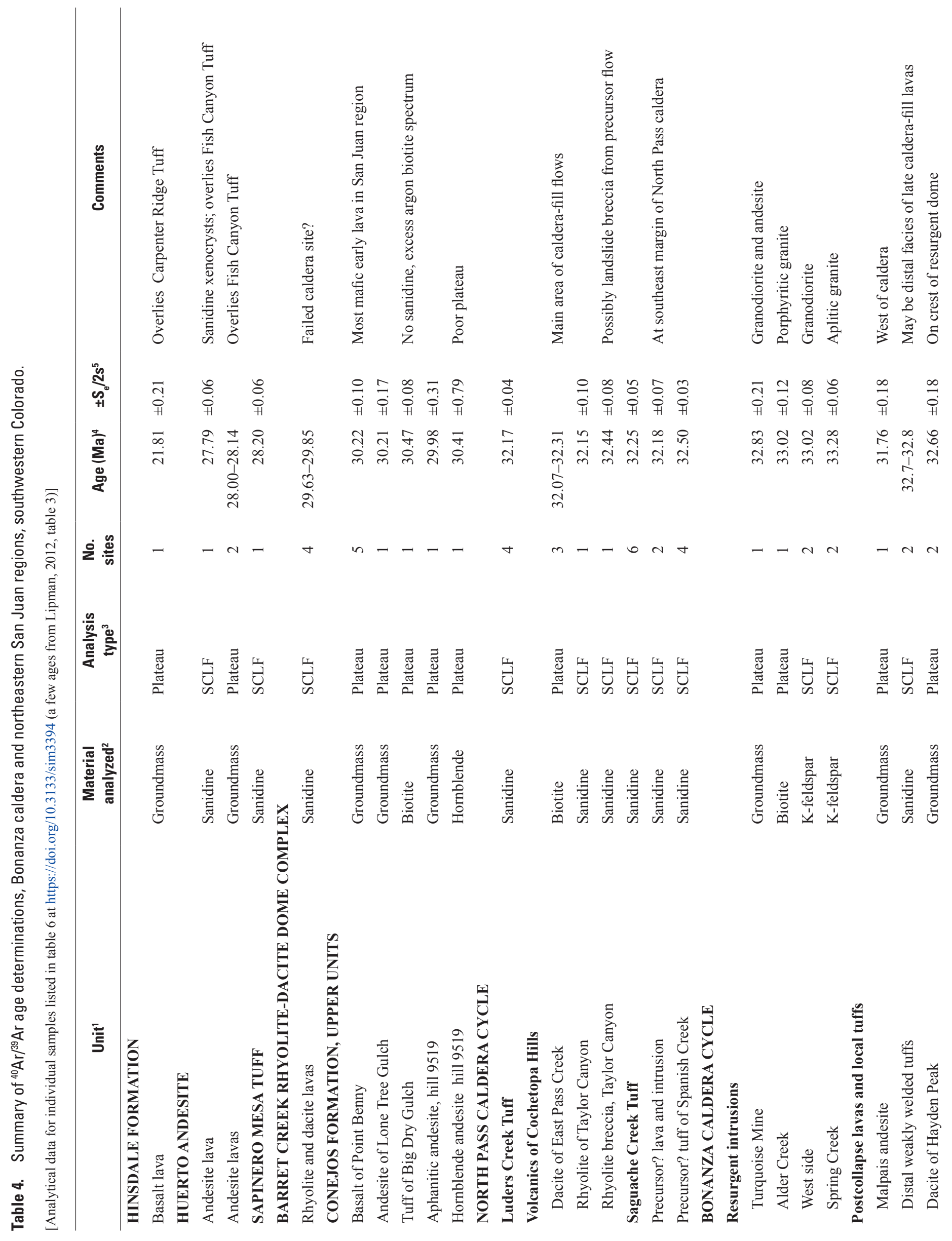




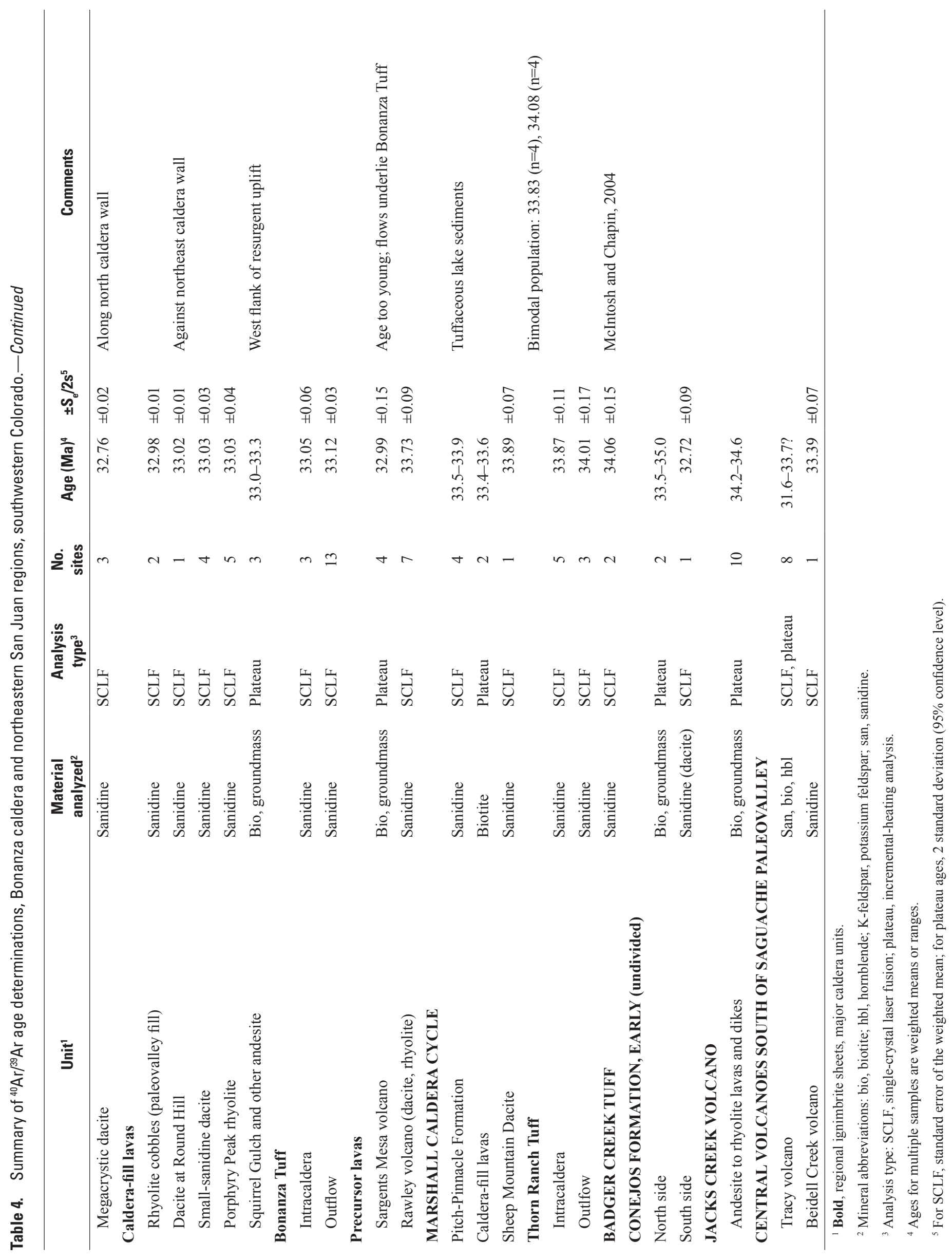

